\author{
UNIVERSIDADE DE SÃO PAULO \\ FACULDADE DE FILOSOFIA, LETRAS E CIÊNCIAS HUMANAS \\ DEPARTAMENTO DE LETRAS CLÁSSICAS E VERNÁCULAS \\ PROGRAMA DE PÓS-GRADUAÇÃO EM FILOLOGIA E LÍNGUA PORTUGUESA
}

SOLANGE UGO LUQUES

Metáfora e argumentação: uma análise crítica do
discurso político

São Paulo

2010 


\author{
UNIVERSIDADE DE SÃO PAULO \\ FACULDADE DE FILOSOFIA, LETRAS E CIÊNCIAS HUMANAS \\ DEPARTAMENTO DE LETRAS CLÁSSICAS E VERNÁCULAS \\ PROGRAMA DE PÓS-GRADUAÇÃO EM FILOLOGIA E LÍNGUA PORTUGUESA
}

\title{
Metáfora e argumentação: uma análise crítica do discurso político
}

Solange Ugo Luques

Dissertação apresentada ao Programa de PósGraduação em de Filologia e Língua Portuguesa, do Departamento de Letras Clássicas e Vernáculas da Faculdade de Filosofia, Letras e Ciências Humanas da Universidade de São Paulo, para a obtenção do Título de Mestre.

Orientadora: Profa. Dra. Zilda Gaspar Oliveira de Aquino 
Catalogação na Publicação

Serviço de Biblioteca e Documentação

Faculdade de Filosofia, Letras e Ciências Humanas da Universidade de São Paulo

Luques, Solange Ugo

Metáfora e argumentação : uma análise crítica do discurso político / Solange Ugo Luques ; orientadora Zilda Gaspar Oliveira de Aquino. - São Paulo, 2010.

172 f. ; il.

Dissertação (Mestrado) - Faculdade de Filosofia, Letras e Ciências Humanas da Universidade de São Paulo. Departamento de Letras Clássicas e Vernáculas. Área de concentração: Filologia e Língua Portuguesa.

1. Metáfora. 2. Argumentação. 3. Análise do discurso. 4. Discurso político. I. Título. II. Aquino, Zilda Gaspar de Oliveira.

CDD 401.41 
Autorizo reprodução e divulgação totais ou parciais deste trabalho, por qualquer meio convencional ou eletrônico, para fins de estudo e pesquisa, desde que citada a fonte. 
Nome: LUQUES, Solange Ugo

Título: Metáfora e argumentação: uma análise crítica do discurso político

Dissertação apresentada ao Programa de PósGraduação em de Filologia e Língua Portuguesa, do Departamento de Letras Clássicas e Vernáculas da Faculdade de Filosofia, Letras e Ciências Humanas da Universidade de São Paulo, para a obtenção do Título de Mestre.

Aprovada em:

Banca Examinadora:

Julgamento:

Assinatura:

Julgamento:

Assinatura:

Julgamento:

Assinatura: 
Aos meus amores,

Luiz Carlos,

Isabela,

Mariana e

Nélia,

Que me incentivaram a começar, colaboraram pacientemente de muitas formas e foram companheiros nessa minha aventura intelectual. 


\section{AGRADECIMENTOS}

A Deus, pela vida.

À Professora e Orientadora Dra. Zilda Gaspar Oliveira de Aquino, que me aceitou como sua orientanda, confiou em mim, mostrou-me um mundo novo e me guiou por ele com firmeza e carinho. Não esquecerei sua acolhida amiga, seus ensinamentos nem seus exemplos.

Às Professoras Doutoras Elisa Guimarães e Dieli Vesaro Palma, pelo respeito que demonstraram em relação a mim e a meu trabalho e propriedade com que me aconselharam durante o processo de Qualificação. Reafirmo minha admiração pela excelência do conhecimento que possuem e pela generosidade com que o partilharam comigo.

À Universidade de São Paulo, USP, por ter me concedido a oportunidade e o espaço para desenvolver este trabalho, principalmente aos professores de cujas aulas participei.

A meu marido, Luiz Carlos, por seu amor, sua paciência, seu bom humor e seu incentivo.

Às minhas filhas Isabela e Mariana, por existirem e serem as pessoas excelentes que são. Por seu apoio, seu carinho e ânimo nas horas difíceis. A Fernando e Leandro por amá-las.

À minha mãe, Nélia, minha eterna defensora, conselheira, colaboradora, companheira de todas as horas. É uma bênção de Deus tê-la a meu lado como exemplo de entusiasmo pela vida.

À minha avó, Lina Cândida, meu avô Sylvio e meu pai, Giuseppe. Sinto que, onde quer que estejam, ainda me acompanham e vibram com minhas realizações.

A meu irmão Antônio, meus sogros e todos os parentes e amigos que me apoiaram e incentivaram, mesmo sem compreender muito bem o que eu fazia.

A todos os colegas de estudos e pesquisas com quem convivi neste período, mas principalmente às amigas Rafaela Baracat Ribeiro e Daniela da Silveira Miranda. Ao Evandro, à Rosani, à Adriana e à Rosana, pelo incentivo.

À Bruna Wysocki, por ter permitido que eu usasse seu corpus transcrito (Programa Livre) como parte desta dissertação. 
Os estudiosos do discurso são unânimes ao afirmarem que o discurso produz e transforma a realidade.

\section{Zilda Aquino}




\section{RESUMO}

LUQUES, S. U. Metáfora e argumentação: uma análise crítica do discurso político. 2010. 172 f. Dissertação (Mestrado) - Faculdade de Filosofia, Letras e Ciências Humanas da Universidade de São Paulo, 2010.

O presente trabalho tem como proposta estudar os efeitos de sentido produzidos pelo emprego de metáforas discursivas, enquanto escolhas linguísticas contextualizadas culturalmente e transmissoras de ideologia, como estratégia argumentativa construtora de significado. Além de constituírem estratégia argumentativa de eficácia já comprovada por estudiosos como Perelman e Olbrechts-Tyteca (2005 [1958]), as metáforas podem também revelar valores e ideologias, pois, como dizem Lakoff e Johnson (2002[1980]), nosso sistema conceptual é basicamente metafórico, portanto, nosso pensamento é metaforicamente estruturado e sua manifestação através da enunciação é reveladora da relação que temos com o mundo. Neste estudo, em que se procede à análise de pronunciamentos e entrevistas de Fernando Collor de Mello, por se tratar de análise do discurso político, optou-se ainda por utilizar como abordagem teórico-metodológica a Análise Crítica do Discurso (ACD), conforme proposta de Fairclough (1997), instrumento de estudo da linguagem como prática social, forma de ação sobre o mundo. O objetivo é fazer um estudo crítico no intuito de desvendar a maneira pela qual alguém exerce o controle sobre uma ocasião social através das formas linguísticas que emprega (WODAK, 2004). As Teorias da Metáfora e a Análise Crítica do Discurso encontram seu ponto de convergência na proposta teórica de Charteris-Black (2004), a Análise Crítica da Metáfora. Definida por seu autor como uma abordagem semânticocognitiva que analisa criticamente metáforas presentes em discursos e manifestos políticos para evidenciar sua importância como veículo da ideologia no discurso de áreas em que influenciar julgamentos é um objetivo central, a ACM (Análise Crítica da Metáfora) foi incluída nessa pesquisa dada a sua pertinência no estudo das escolhas metafóricas de Fernando Collor de Mello. Foram selecionadas algumas formulações discursivas atribuídas ao referido político, ex-presidente da República do Brasil e atual senador pelo estado de Alagoas, amostras que, acredita-se, retratam momentos diversos de sua atribulada trajetória política, ilustrando o teor de sua relação com o poder. A hipótese é que as metáforas nelas utilizadas sejam reveladoras de aspectos cognitivos, culturais e ideológicos da visão de mundo de Fernando Collor, constituam sua identidade e sejam eficientes estratégias argumentativas, visto que se estabelecem como forma de ação e interação persuasiva em um meio social. A análise do corpus permitiu observar que Collor, por meio da linguagem metafórica que emprega em seus discursos, frequentemente apela à emoção e ao imaginário de seus interlocutores na tentativa de construir uma identidade de força e combatividade e de fazê-los aderirem às suas ideias; torna, assim, suas manifestações discursivas em fértil campo de estudo sobre transmissão de ideologia e habilidade argumentativa.

Palavras-chave: Metáfora. Argumentação. Análise crítica do discurso. Discurso político. Análise crítica da metáfora. 


\begin{abstract}
LUQUES, S. U. Metaphor and argumentation: a critical analysis of political discourse. 2010. 172 f. Tese (Mestrado) - Faculdade de Filosofia, Letras e Ciências Humanas da Universidade de São Paulo, 2010.
\end{abstract}

This work proposes to study the effects of meaning produced by the use of discursive metaphors, while culturally contextualized linguistic choices and ideology transmitters, as an argumentative strategy of meaning construction. In addition to being an argumentative strategy whose effectiveness was already proven by scholars such as Perelman and OlbrechtsTyteca (2005 [1958]), metaphors can also reveal values and ideologies, because, according to Lakoff and Johnson (2002 [1980]), our conceptual system is basically metaphorical, so our thought is metaphorically structured and its manifestation through language use may reveal our relationship with the world. In this political discourse study, which carries out the analysis of some of Fernando Collor de Mello's speeches and interviews, the option was to use Critical Discourse Analysis (CDA) as a theoretical and methodological approach proposed by Fairclough (1997), an instrument for language study as social practice, action over the world, therefore. The goal is to make a critical study in order to reveal how one exerts control over a social occasion through linguistic forms he employs. (Wodak, 2004). Metaphor Theories and Critical Discourse Analysis find their point of convergence in Charteris-Black (2004) theoretical proposal, Critical Metaphor Analysis. Defined by its author as a semanticcognitive approach that critically examines metaphors in political speeches and manifestos to highlight its importance as a vehicle of ideology in areas where influencing judgments is a central discourse goal, CMA (Critical Metaphor Analysis) was included in this research given its relevance in the study of Fernando Collor de Mello metaphorical choices. Some discursive formulations assigned to that politician, former Brazil's president and current senator for the state of Alagoas, were selected, samples believed to depict different moments of his eventful political career, illustrating the content of his relationship with power. The hypothesis is that metaphors used in them are indicative of Fernando Collor's cognitive, cultural and ideological worldview, constitute his identity and work as efficient argumentative strategies, since they set themselves as ways of persuasive action and interaction in a social environment. Corpus analysis helped identify that Collor, by employing metaphorical language in his speeches, often appeals to his counterparts emotion and imagination, in an attempt to build an identity of force and toughness and to make them adhere to his ideas, thus turning his discursive manifestations into a fertile field of study on ideology transmission and argumentative skills.

Keywords: Metaphor. Argumentation. Critical discourse analysis. Political discourse. Critical metaphor analysis. 


\section{LISTA DE QUADROS}

Quadro 1. Correspondência entre as Contribuições do discurso, as Funções e os

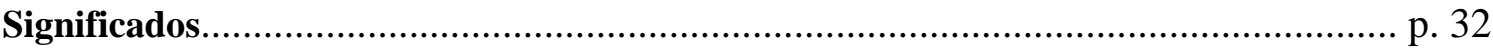

Quadro 2. Modelo hierárquico-cognitivo de metáfora ................................................. p. 39

Quadro 3. Esquema da Tríplice perspectiva de observação da metáfora …................. p. 73

Quadro 4 . Modelo hierárquico-cognitivo de metáforas presentes no discurso de

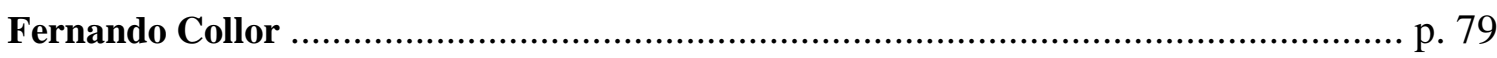




\section{SUMÁRIO}

INTRODUÇÃO 12

\section{CAPÍTULO I}

DISCURSO POLÍTICO, ANÁLISE CRÍTICA DO DISCURSO E TEORIAS DA METÁFORA

1.1 Discurso político: lugar de um jogo de máscaras 23

1.2 Modelo mental como base da cognição política: elo entre ideologias e discurso.

1.3 Modelo tridimensional de análise de Fairclough 30

1.4 Teorias da metáfora: Aristóteles, Lakoff e Johnson, e Charteris-Black .. 34

\section{CAPÍTULO II}

\section{A METÁFORA E SUAS INTER-RELAÇÕES: CULTURA, IDEOLOGIA E IDENTIDADES}

2.1 Cultura, Ideologia e o "esquema da FORÇA". 45

2.2 O papel da metáfora na construção de identidades e na transmissão de ideologias

2.2.1 A seleção de uma metáfora em particular.

\section{CAPÍTULO III}

\section{ARGUMENTAÇÃO E METÁFORA - A TRÍPLICE PERSPECTIVA}

3.1 Por que as pessoas falam metaforicamente?

3.2 A Teoria da Argumentação : Metáfora como estratégia argumentativa 


\section{ANEXOS}

ANEXO A - Transcrição de propaganda eleitoral da campanha a presidente da República

ANEXO B - Reprodução do discurso de posse no Parlatório 93

ANEXO C - Reprodução do relato "Crônica de um golpe" .95

ANEXO D - Reprodução da transcrição da entrevista televisiva ao Programa Livre 106

ANEXO E - Reprodução da entrevista à revista Istoé Gente, versão eletrônica 124

ANEXO F - Reprodução do discurso de posse como senador no Congresso Nacional 129

ANEXO G - Reprodução e transcrição de segmento de discurso da campanha a governador de Alagoas ....

ANEXO H - Normas para transcrição - Projeto NURC-SP

ANEXO I - Reprodução em mídia digital da propaganda da campanha a presidente da República (ANEXO A) e do segmento de discurso da campanha a governador de Alagoas (ANEXO G) 


\section{INTRODUÇÃO}


Inúmeros pesquisadores de todos os tempos já tomaram a metáfora como objeto de estudo, incluindo-se entre eles Aristóteles, no século IV a.C., em sua Arte Poética. Os estudiosos do discurso interessam-se especialmente por observar as teorias que a consideram estratégia persuasiva que visa a convencer o interlocutor através da emoção, em oposição à razão (Perelman e Tyteca, 2005 [1958]); há ainda os que propõem o estudo das teorias cognitivas da metáfora, como Lakoff e Johnson (2002 [1980]), dizendo ser nosso sistema conceitual de natureza metafórica, pois certas metáforas estruturam nossa maneira de perceber, pensar e agir.

Outro enfoque bastante atual é o de Charteris-Black (2004), que se utiliza de uma abordagem semântico-cognitiva e analisa criticamente metáforas presentes em discursos e manifestos políticos, propondo o que ele chama Análise Crítica da Metáfora, para evidenciar sua importância como veículo da ideologia no discurso de áreas em que influenciar julgamentos é um objetivo central.

No Brasil, há diversos estudos sobre metáfora, seja ela empregada no discurso pedagógico, científico, jornalístico ou político, dentre os quais se destacam as obras de Palma (1998), que estuda a leitura das figuras de pensamento, considerando-as manifestações linguísticas de processos cognitivos, e Sardinha (2007), que afirma serem as metáforas recursos retóricos poderosos e procede a algumas análises de seu emprego em textos de gêneros diversos.

O contato com o trabalho desses estudiosos permitiu observar a possibilidade de se contribuir para os estudos discursivos em língua portuguesa ao tomar como objeto de estudo o discurso político produzido por brasileiros. Em se tratando especificamente das manifestações de Fernando Collor, grande parte delas proporciona ao pesquisador do discurso fonte em geral abundante para a análise da linguagem metafórica, em especial quando se busca desvendar a ideologia e a força argumentativa nela contidas, principalmente por seu caráter emocional, mais que racional.

Além disso, como afirma Meyer (2007, p.82), a metáfora é "a figura por excelência da identidade frágil”, pois ela não diz, apenas deixa subentendido o significado, convidando o outro a concluí-lo e apresentando-se, portanto, como momento de conciliação discursiva fato que a qualifica como estratégia argumentativa sutil, que encanta antes de persuadir. Pode-se dizer que o locutor é o responsável pela produção da metáfora discursiva, mas sua interpretação é partilhada com o interlocutor, pois nela cabem muitos significados implícitos 
ou subentendidos, que, segundo Ducrot (1987), são as conclusões desse interlocutor, que ocorrem em momento posterior ao ato de comunicação, como se tivessem sido acrescentadas através da interpretação dele.

$\mathrm{Na}$ área do discurso político, a metáfora pode ser considerada recurso significativo, pois, como afirma Charaudeau (2008), aquele é o "lugar de um jogo de máscaras", em que toda palavra deve ser considerada pelo que diz e também pelo que não diz, o que novamente aponta para a importância do estudo da linguagem metafórica nas manifestações discursivas de cunho político, pela capacidade que apresenta de transportar simultaneamente significados de superfície e outros tantos subjacentes.

Levando-se ainda em consideração Aquino (2004), para quem o discurso político, como campo de investigação, pode certamente ser objeto de estudos que permitam captar suas diversas dimensões e compreender sua organização, busca-se responder, com esta pesquisa, a alguns questionamentos que surgiram a partir de um contato mais aprofundado com o discurso de Fernando Collor, a saber:

- Como se manifestam as metáforas, no discurso político de Fernando Collor, e de que modo sua análise auxilia a compreender a organização do processo cognitivo desse locutor?

- Que aspectos culturais e ideológicos acerca da visão de mundo e da ação política de Fernando Collor podem ser conhecidos a partir do estudo da linguagem metafórica utilizada por ele ao construir sua identidade e expressar suas ideias?

- Que perspectivas da relação de poder estabelecida entre Fernando Collor e seu auditório podem ser detectadas pela análise crítica da metáfora, tendo em vista seu caráter eminentemente persuasivo?

A partir do que se apresenta, este trabalho visa a contribuir para o desenvolvimento das pesquisas no domínio do discurso político, por meio de um estudo das metáforas empregadas por Fernando Collor de Mello em suas manifestações discursivas. Busca-se compreender o funcionamento e as particularidades da formulação de seu discurso, por meio de uma investigação crítica e pela abordagem de fatores de ordem cognitiva, ideológicocultural e argumentativa na relação que tal locutor mantém com seu auditório.

O corpus constitui-se de amostras em que se levou em conta a representatividade nos momentos de ápice, queda e retomada de poder na carreira de Fernando Collor de Mello. Elas foram tomadas do domínio do discurso político e selecionadas por traduzirem momentos marcantes da história pública desse político, a saber, a campanha à Presidência da República 
em 1989, a posse para o cargo de presidente em 1990, a ocasião do Impeachment em setembro de 1992, seu exílio do poder nos anos seguintes e sua volta à vida pública ao elegerse senador por Alagoas em 2006, com mandato de oito anos iniciado em fevereiro de 2007, e sua campanha ao governo de Alagoas em 2010. A reprodução dessas sete manifestações discursivas encontra-se na seção de Anexos da presente pesquisa (vide p. 90). Segue detalhamento das amostras do corpus elencadas em ordem cronológica de ocorrência:

- Transcrição ${ }^{1}$ de uma propaganda eleitoral da campanha a presidente da República em 1989 e a sua reprodução em mídia digital, tal como foi veiculada pelas emissoras de televisão durante o horário eleitoral gratuito. O vídeo da referida propaganda foi recuperado por meio eletrônico através do arquivo de imagens:

http://www.youtube.com/watch?v=tVAPdnNOVxU, e a transcrição, necessária em razão de se tratar de texto falado, foi feita segundo as normas instituídas pelo projeto NURC-SP, também relacionadas ao final dos anexos. (ANEXO A)

- Reprodução do discurso de posse proferido no Parlatório do Palácio do Planalto, um equivalente resumido do discurso de posse como presidente em 1990, cuja transcrição foi recuperada no site pessoal de Fernando Collor de Mello, em 27/02/2010, pelo link http://www.collor.com/discursos1990_002.asp. (ANEXO B)

- Reprodução do relato denominado "Crônica de um golpe”, referente à saída do governo, na ocasião do processo de Impeachment, retirado do site pessoal de Fernando Collor de Mello, em 27/02/2010, pelo link http://www.collor.com/livro.asp. Também há uma versão praticamente igual a essa amostra publicada na Revista Veja, exemplar número 1515, de $1^{\circ}$. de outubro de 1997, em reportagem que teve o título de "A voz do vencido", em que ele apresenta o segmento como sendo o primeiro capítulo do livro Crônica de um Golpe - A Versão de Quem Viveu o Fato, que ele supostamente estaria escrevendo sobre sua passagem pela Presidência e memórias sua infância, família e carreira. Preferiu-se a versão do site pessoal. (ANEXO C)

- Reprodução da transcrição de uma entrevista televisiva concedida em agosto de 1998 ao Programa Livre, transmitido ao vivo pelo Sistema Brasileiro de Televisão (SBT), em que o ex-presidente é entrevistado por jovens estudantes mediados pelo apresentador Sérgio Groisman. A referida transcrição foi retirada, com a autorização da autora, da dissertação de Mestrado pela FFLCH-USP de Bruna Wysocki, Interação face a face: um estudo das

\footnotetext{
${ }^{1}$ A transcrição das amostras de discurso falado foi feita a partir das normas instituídas pelo projeto NURC-SP, projeto que estuda a Norma Linguística Urbana Culta de São Paulo.
} 
estratégias discursivas na reconstrução da imagem, de 2007, que pode ser acessada através do link http://www.teses.usp.br/teses/disponiveis/8/8142/tde-05052008-153601/. (ANEXO D)

- Reprodução da entrevista concedida à repórter Neuza Sanches e publicada na página eletrônica da revista Istoé Gente, na edição de número setenta e quatro do final de 2000, quando se encerrava o período de oito anos de afastamento político a que foi condenado por consequência do Impeachment, acessada em 27/02/2010 pelo link http://www.terra.com.br/istoegente/74/entrevista/index.htm. (ANEXO E)

- Reprodução da transcrição do discurso de posse no Congresso Nacional como senador pelo estado de Alagoas, em 15 de março de 2007, assim como publicada na página eletrônica do Senado Federal e que foi acessada em 27/02/2010 pelo link http://www.senado.gov.br/sf/atividade/pronunciamento/detTexto.asp?t=367005. Há outras versões deste discurso, uma delas na página pessoal de Fernando Collor, porém foi tomada a decisão de analisar-se a versão publicada na página do Senado por motivo de considerá-la, em tese, mais próxima da que foi efetivamente pronunciada por Fernando Collor no dia de sua posse como senador. (ANEXO F)

- Reprodução da imagem do texto publicado na Revista Veja, edição 2172 - ano 43 - no. 27, de 7 de julho de 2010, de versão de um segmento do discurso proferido por Fernando Collor, na capital Maceió, em 30 de junho de 2010, no lançamento de sua candidatura ao governo de Alagoas. Acompanha a transcrição da voz de Fernando Collor, segundo as normas instituídas pelo projeto NURC-SP, do audiovisual do segmento correspondente, recuperado por meio do link de arquivo eletrônico de imagens acessado em 26/08/2010: http://www.youtube.com/watch?v=fSd89VeqwlQ\&feature=related, com reprodução em mídia digital. (ANEXO G)

- Reprodução em mídia digital da propaganda da campanha a presidente da República (ANEXO A) e do segmento de discurso da campanha a governador de Alagoas (ANEXO G). (ANEXO I)

$\mathrm{Na}$ ocasião em que foram proferidas, todas essas manifestações discursivas, cuja reprodução totaliza aproximadamente 31.800 palavras, foram registradas e transmitidas através da mídia e, para esta pesquisa, foram recuperadas principalmente através de arquivos eletrônicos disponibilizados no site pessoal do próprio ex-presidente, http://www.collor.com/, da sua página atual como senador no site do senado, http://www.senado.gov.br/sf/, do arquivo de imagens do site de busca http://www.youtube.com/, bem como de revistas de circulação 
nacional, como a Revista Veja e a IstoÉ Gente, esta disponibilizada em meio eletrônico em http://www.terra.com.br/istoegente.

O corpus foi selecionado pela sua representatividade semântica e não pela categoria de gênero, portanto, as manifestações discursivas que o compõem são de diferentes gêneros, a saber: propaganda e discurso eleitorais, discurso de posse de cargo político, entrevista para a mídia eletrônica, entrevista em programa televisivo e relato. Observa-se que esta composição inclui material falado e escrito, tendo em vista a hipótese de que a utilização de linguagem metafórica poderia ocorrer nas duas modalidades do discurso desse político.

Como meio auxiliar de análise do corpus, os estudos discursivos em geral, e a ACD em particular, apontam para a importância crucial de se considerar o contexto de uso da linguagem, em seus aspectos históricos e sociais, visto que, segundo Fairclough (2001), o discurso, moldado e restringido pela estrutura social, é prática de representação e significação do mundo, contituindo-o e construindo-o em significado. Para esta pesquisa, importa, sobretudo, situar histórica, cultural e socialmente a figura do locutor, Fernando Collor de Mello, com a finalidade de conhecer um pouco mais sobre sua vida pública e privada e, assim, contextualizar sua prática discursiva.

Foram consultadas várias fontes bibliográficas, entre elas o CPDOC, o Centro de Pesquisa e Documentação de História Contemporânea do Brasil, da Escola de Ciências Sociais e História da Fundação Getúlio Vargas, por meio dos links: http://cpdoc.fgv.br/producao/dossies/FatosImagens/FernandoCollor http://www.fgv.br/CPDOC/BUSCA/Busca/BuscaConsultar.aspx, e uma resumida apresentação das informações encontradas inclui dizer que Fernando Collor nasceu no Rio de Janeiro, então Distrito Federal, no dia 12 de agosto de 1949, filho de Leda Collor de Melo e de Arnon de Melo, que foi governador (1951-1956) e senador por Alagoas (1963-1981). Seu avô materno, Lindolfo Collor, foi deputado federal pelo Rio Grande do Sul e foi um dos líderes da Revolução de 1930 e, ao afastar-se politicamente de Getúlio Vargas, em 1932, participou da Revolução Constitucionalista de São Paulo.

O fato de a carreira política do pai, Arnon de Mello, ter-se desenvolvido entre as cidades de Maceió, Rio de Janeiro e Brasília teve influência na vida acadêmica de Fernando Collor. Ele estudou em colégios cariocas entre 1962 e 1966 e, ao mudar-se para Brasília em 1967, lá cursou o Ensino Médio e formou-se em Ciências Contábeis na União Pioneira de Integração Social (UPIS). 
Em 1972, então em Maceió, assumiu a direção da Gazeta de Alagoas, jornal de propriedade de seu pai e, um ano depois, tornou-se superintendente da Organização Arnon de Melo, grupo empresarial da família, constituído pelo jornal, a TV Gazeta, três emissoras de rádio e uma gráfica. Curiosamente, no site oficial da Presidência da República, página do vigésimo quarto período de Governo Republicano da Galeria dos Presidentes, a profissão de Fernando Collor é de jornalista. (Acesso em 02/08/2010, pelo link:

http://www.presidencia.gov.br/info_historicas/galeria_pres/galcollor/galcollor/integrapresiden te $\operatorname{view} /$ )

Antes de se eleger presidente, Fernando Collor de Mello foi prefeito nomeado de Maceió em 1979, deputado federal em 1983 e governador de Alagoas em 1987, quando se tornou conhecido como “Caçador de Marajás', denominação metafórica que o acompanhou mais tarde na campanha à presidência da República, por ter empreendido um combate a alguns funcionários públicos alagoanos que ganhavam altos salários.

Collor foi escolhido por maioria popular na primeira eleição direta para presidente, depois de 25 anos de um regime de exceção, mas exerceu o cargo de presidente da República apenas de março de 1990 a dezembro de 1992, quando renunciou, tentando sem sucesso escapar ao processo de Impeachment que cassou seus direitos políticos por oito anos. Durante esse período, o ex-presidente tentou reverter sua situação por meios jurídicos e políticos, mas não obteve sucesso. Atravessou, desde então, períodos conturbados na vida particular com a morte do irmão, da mãe e o assassinato de Paulo César Farias, o ex-tesoureiro de sua campanha. Mudou-se para Miami em 1995, onde, de acordo com suas próprias afirmações, vivia do pró-labore recebido das empresas da família, e lá permaneceu até 1998.

Voltou ao Brasil e concorreu a diversos cargos, mas só foi eleito novamente na campanha de 2006, tomando posse como senador pelo Estado de Alagoas, em 15 de março de 2007. Resolveu adotar a questão ambiental como objetivo principal de sua atuação como senador. No início de 2009, Collor tornou-se presidente da Comissão de Serviços de Infraestrutura do Senado Federal e membro titular da Comissão de Relações Exteriores e Defesa Nacional e da Comissão de Acompanhamento de Metas Fixadas pela ONU. No segundo semestre de 2010, lançou sua candidatura ao governo do estado de Alagoas.

Como procedimento metodológico, decidiu-se iniciar pelo rastreamento da ocorrência de metáforas e linguagem metafórica em cada uma das manifestações discursivas que compõem o corpus, para que fosse possível observar sua frequência e reprodução, com o objetivo de estabelecer, para cada amostra, uma ou mais metáforas conceptuais, que seriam, 
segundo Lakoff e Johnson (2002 [1980]), o conceito metafórico estruturador de uma atividade cotidiana que envolve a compreensão de um domínio da experiência em termos de um domínio diferente de experiência.

Para esta pesquisa, acredita-se ser relevante analisar os significados comuns das metáforas encontradas no corpus e estabelecer um conceito estruturador que envolva um domínio alvo e um domínio fonte, isto é, um domínio referente aos conceitos definidos metaforicamente, e outro, de onde se originam as metáforas escolhidas para defini-los, respectivamente. Tal interesse decorre da concepção de que estabelecer tais domínios concorreria para conhecer os processos cognitivos e as bases culturais e ideológicas de que resultaram as escolhas metafóricas do locutor.

A esse respeito, Charteris-Black (2004) afirma que um grande número de estudiosos do tema, entre eles Schön (1993), MacCormac (1976), Lakoff \& Johnson (1980), Grady (1997) e Goatly (1997), entende que as metáforas não podem ser classificadas com um critério linguístico superficial, porque elas são resultado de processos cognitivos subjacentes que também precisam ser representados. Aquele autor propõe que conhecer a motivação de determinado locutor em domínios do uso de linguagem socialmente influente melhora o entendimento, por parte do analista, da base ideológica para a escolha metafórica e contribui para a construção teórica, pois proporciona acesso a pensamentos que são a base do uso da linguagem.

O que se indicou como procedimento metodológico inicial (último $\S$ da p. 18) corresponde à primeira parte do método tridimensional de Análise do Discurso proposto por Fairclough (2001) e aqui adotado. Trata-se da identificação e descrição de aspectos linguísticos significativos do corpus, no presente trabalho metáforas e linguagem metafórica, com a respectiva abstração das metáforas conceptuais. Estas, acredita-se, representam o elo entre ideologia e argumentação, pois representam escolhas que o locutor faz com o objetivo de persuadir seu auditório.

O segundo passo do método tridimensional de Fairclough propõe a interpretação das relações entre os processos discursivos produtivos e interpretativos. Neste estudo, prioriza-se a interpretação dos processos discursivos produtivos, com ênfase na análise dos aspectos culturais e das estratégias utilizadas por Fernando Collor para a construção da imagem de si que este locutor quer transmitir a seus interlocutores, com o propósito retórico da persuasão, e o estudo do contex to em que os discursos selecionados ocorreram. 
A terceira etapa do modelo de Fairclough recomenda uma explicação da relação entre os processos discursivos e os processos sociais, isto é, aconselha que se proceda a um esclarecimento de como a prática discursiva pode ter afetado um processo social, provocando uma mudança.

Certamente, tem-se consciência, como analista, de que é o efeito combinado de várias estratégias argumentativas que confere eficiência ao discurso político (Cf. CHARTERISBLACK, 2005), porém, acredita-se ser possível comprovar a importante colaboração das metáforas na produção de um discurso que pode ser apontado como causador de diversas transformações no comportamento de grande parcela da população brasileira e no cenário político brasileiro em geral.

A interface da Análise Crítica do Discurso de Fairclough com a Teoria da Argumentação ocorre a partir de uma Análise Crítica da Metáfora, conforme proposta de Charteris-Black (2004) e descrita mais adiante, que postula ser a seleção metafórica em tipos particulares de discurso governada pelo propósito retórico da persuasão, portanto, motivada pela ideologia.

A proposta de organização dos capítulos da dissertação é a seguinte:

\section{CAPÍTULO I - DISCURSO POLÍTICO, ANÁLISE CRÍTICA DO DISCURSO E METÁFORA}

Levantamento das teorias relativas ao Discurso Político segundo Charaudeau (2005) e à Análise Crítica do Discurso, apresentando a teoria do Modelo mental como base da cognição política e elo entre as ideologias e o discurso. Detalhamento do Modelo Tridimensional de Análise de Fairclough (2001), que indica os procedimentos da descrição, interpretação e explicação como os mais adequados a uma Análise Crítica do Discurso. Revisão teórica sobre a Metáfora, com a apresentação de alguns enfoques através dos tempos, chegando às atuais teorias sociocognitivas e à proposta de uma Análise Crítica da Metáfora. Aplicação da teoria na análise de exemplos extraídos do corpus.

\section{CAPÍtUlO II - A METÁFORA E SUAS INTER-RELAÇÕES: CULTURA, IDEOLOGIA E IDENTIDADES}


Levantamento dos pressupostos teóricos sobre Cultura, Ideologia e Construção de Identidades, sobretudo quanto à questão do uso da metáfora discursiva como transmissora de ideologia. Apresentação do 'esquema de FORÇA' como esquema imagético básico que estrutura o sistema conceptual. Aplicação da teoria na análise de exemplos extraídos do corpus.

\section{CAPÍTULO III - ARGUMENTAÇÃO E METÁFORA: A TRÍPLICE PERSPECTIVA}

Revisão teórica sobre as funções da Metáfora, as hipóteses de expressabilidade, compactividade e vivacidade,e em especial em seu emprego como estratégia argumentativa inserida no campo da Teoria da Argumentação. Apresentação da Tríplice Perspectiva de Observação da Metáfora, nos aspectos Cognitivos, Ideológico-culturais e Argumentativos. Aplicação da teoria na análise de exemplos extraídos do corpus.

ANEXOS: localizam-se a reprodução do corpus, o CD com os vídeos dos ANEXOS A e G, além das normas de transcrição do Projeto NURC-SP.

E a metáfora consistiria em expressar os vínculos secretos entre as coisas. 


\section{CAPÍTULO I}

\section{DISCURSO POLÍTICO,}

ANÁLISE CRÍTICA DO DISCURSO

E

METÁFORA 


\subsection{Discurso político: lugar de um jogo de máscaras}

Quando Charaudeau (2005, p. 8) define o discurso político como o lugar de um jogo de máscaras, ele utiliza o conceito de máscara como "símbolo de identificação, a ponto de nela se confundirem o ser e o parecer, a pessoa e o personagem, tal como no teatro grego.”. Para ele, o sentido que nasce de todo ato de linguagem é o resultado do encontro entre o sujeito que enuncia e o outro que interpreta. Estes dois sujeitos agiriam em função da imagem que têm um do outro, e sua identidade seria a imagem co-construída resultante desse encontro. As máscaras, portanto, constituiriam o ser presente, não necessariamente falsas ou enganosas, mas o próprio ser em sua verdade da troca em uma situação determinada, constituindo uma identidade em relação ao outro. Ele afirma que:

Toda palavra pronunciada no campo político deve ser tomada ao mesmo tempo pelo que ela diz e não diz. Jamais deve ser tomada ao pé da letra, numa transparência ingênua, mas como resultado de uma estratégia cujo enunciador nem sempre é soberano. (op. cit., p. 9)

Segundo esse estudioso, um linguista do discurso não pode ignorar que a linguagem não faz sentido se não for considerada em um contexto psicológico e social e, como consequência, ele deve integrar à análise linguística conceitos de outras disciplinas humanas e sociais. Entende ser preciso questionar a natureza e o funcionamento do que ele inicialmente denomina palavra política, na medida em que "ela se inscreve em uma prática social, circula em certo espaço público e tem qualquer coisa que ver com as relações de poder que aí se instauram." (op.cit., p. 15)

Os estudos no domínio do discurso político, aponta Charaudeau, geraram diversas questões discutidas atualmente, dentre elas a que considera mais global por abordar a finalidade que a análise do discurso político tem, por ser capaz de revelar "o que é a realidade do poder, este sendo, para alguns, essencialmente uma questão de ação"; afirma, portanto, ser necessário mostrar "que não poderia haver ação política se não houvesse discurso que a motivasse e lhe conferisse sentido." Ele diz que:

O discurso político não esgota, de forma alguma, todo o conceito político, mas não há política sem discurso. Este é constitutivo daquela. A linguagem é o que motiva a ação, a orienta e lhe dá sentido. A política depende da ação e se inscreve constitutivamente nas relações de influência social, e a linguagem, em virtude do fenômeno de circulação dos discursos, é o que permite que se constituam espaços de discussão, de persuasão e de sedução nos quais se elaboram o pensamento e a ação políticos. A ação 
política e o discurso político estão indissociavelmente ligados, o que justifica pelo mesmo raciocínio o estudo político pelo discurso. (op. cit., p. 39)

Charaudeau também afirma que a situação de comunicação é que torna o discurso político, portanto, o conteúdo do discurso não é político, mas a situação é que o politiza. A produção de sentido no pensamento político é elaborada segundo os modos de interação e a identidade dos interlocutores, o que leva o autor a diferenciar três lugares de fabricação desse pensamento, com características e linguagem particulares: um lugar de elaboração dos sistemas de pensamento, um lugar relacionado ao ato de comunicação e um lugar em que é produzido o comentário.

Segundo esse estudioso, elaborar o discurso político como sistema de pensamento é realizar uma atividade discursiva que procura estabelecer um ideal político "em função de certos princípios que devem servir de referência para a construção de opiniões e dos posicionamentos." (p. 40) É um lugar em que o discurso político é construído de maneira mais rigorosa e teórica, com o objetivo de elaborar um sistema de pensamento coerente que possa suscitar filiações ideológicas.

Como todo discurso social, a característica do discurso político é circular no interior dos grupos que o constituem e até alcançar outros grupos, manifestando-se em diferentes situações de comunicação que podem transformá-lo a ponto de fazê-lo perder suas características originais. Este lugar de elaboração dos sistemas de pensamento não está separado dos outros dois, de ato de comunicação e de comentário, como indica Charaudeau (2005, p. 40):

O discurso político como ato de comunicação, concerne mais diretamente aos atores que participam da cena de comunicação política, cujo desafio consiste em influenciar as opiniões a fim de obter adesões, rejeições ou consensos. Ele resulta de aglomerações que estruturam parcialmente a ação política (comícios, debates, apresentação de slogans, reuniões, ajuntamentos, marchas, cerimônias, declarações televisivas) e constroem imaginários de filiação comunitária, (...) Aqui, o discurso político dedica-se a construir imagens de atores e a usar estratégias de persuasão e de sedução, empregando diversos procedimentos retóricos.

Nesse lugar de fabricação, as características do discurso político são interdependentes do processo comunicativo por meio do qual ele se manifesta. No caso da presente pesquisa, que tomou por objeto de estudo manifestações discursivas de Fernando Collor veiculadas por diferentes meios, tais como a televisão e os endereços eletrônicos, é importante indicar que tipo de influência política cada veículo representa, pois essa informação pode revelar por que algumas estratégias de persuasão podem ser preferidas em detrimento de outras. 
O lugar de fabricação do discurso político como comentário tem uma finalidade que está fora do campo da ação política, pois o discurso a respeito do político é revelador da opinião do sujeito que comenta, mas não necessariamente indicador de seu engajamento na ação política. Como não há no corpus amostra alguma que se constitua em opinião a respeito da ação política de Collor, este estudo atém-se a considerar mais especificamente o discurso político como sistema de pensamento e como ato de comunicação, a ser analisado de forma crítica.

Uma outra questão abordada por Charaudeau (2005) que interessa a esta pesquisa é saber em que medida a persuasão relaciona-se à razão ou aos sentimentos, um debate antigo que remonta a Aristóteles, no século IV a. C. . Desde então, já se intuia que persuadir não se limitava apenas a raciocinar com o interlocutor, mas também que era preciso levá-lo a uma ‘disposição de espírito’ que o orientasse para a direção desejada. Mais atualmente, teóricos da Nova Retórica, como Perelman e Olbrechts-Tyteca (2005 [1958]), afirmam que não se podem descartar os sentimentos em nenhum processo de linguagem que objetiva influenciar o interlocutor. $^{2}$

Nessa acepção, Charaudeau (2005, p. 82) lembra ainda que:

(...) convém distinguir "convicção" de "persuasão". A primeira pertenceria ao puro raciocínio, fundar-se-ia sobre as faculdades intelectuais e estaria voltada para o estabelecimento da verdade. A segunda pertenceria aos sentimentos (hoje em dia, diríamos "ao afeto"), fundar-se-ia sobre os deslocamentos emocionais e estaria voltada para o auditório. O logos, de um lado, o pathos de outro, a que é preciso acrescentar o ethos, que diz respeito à imagem daquele que fala e que é igualmente suscetível de tocar o auditório pela possível identificação deste à pessoa do orador. (...) Na elaboração do discurso interviriam com igual importância categorias de razão e categorias de paixão. É o que, de todo modo, se passa no discurso político.

Também sobre essa questão, Reboul (1998) afirma não aceitar a posição de quem diferencia persuadir, que para ele seria levar a crer em alguma coisa, de convencer, com um significado atribuído de fazer compreender, alegando que tal proposta excessivamente dualista opõe no homem o ser de crença e sentimento ao ser de inteligência e razão, como se as últimas características pudessem se afirmar sem as primeiras. Este autor, porém, acrescenta que a persuasão retórica consiste em levar a crer, sem redundar necessariamente no levar a

\footnotetext{
${ }^{2}$ Estudos que envolvem metáforas e emoções são de extrema importância, citando-se Kövecses (2003), que aborda o papel da linguagem metafórica na transmissão das emoções; entretanto, essa não é a proposta central desta pesquisa.
} 
fazer; o contrário, ou seja, levar alguém a fazer algo sem crer nisso, está mais para o campo da ameaça, não da argumentação.

Outro olhar sobre o discurso político em que se aborda a oposição entre convicção e persuasão é o de Osakabe (1999) que, ao proceder à analise de amostras desse domínio do discurso, faz uma diferenciação entre o que ele chama de discurso político teórico e discurso político militante. Esse estudioso afirma que tal distinção não resulta de uma classificação arbitrária, mas é decorrente das próprias condições de produção de cada um deles, que podem ser determinadas por três critérios complementares, a saber:

... em primeiro lugar, o critério das imagens pressupostas, que o locutor faz do ouvinte e vice-versa; em segundo lugar, o critério da imagem que o locutor faz do referente e da imagem que pressupõe que o ouvinte faz desse mesmo referente; em terceiro lugar, o critério da intenção do ato que o locutor visa praticar sobre o ouvinte e do ato que pratica para a obtenção daquele resultado. (p. 106)

Osakabe também relaciona tal classificação à diferenciação semântica que faz dos termos convencer e persuadir, propondo que o discurso político teórico fica no plano da convicção, da adesão a uma posição; enquanto o discurso político militante está no campo da persuasão, pois visa não só à adesão do interlocutor a uma ideia, mas sua participação ativa para a afirmação dessa proposta.

Em exame inicial das manifestações discursivas de Fernando Collor que correspondem ao período da campanha e posse como presidente (ANEXOS A e B), verificouse a dificuldade em classificar tais amostras segundo essa proposta de Osakabe, visto que, apesar de elaboradas com o objetivo de firmar uma posição teórica, é impossível não notar a sutil sugestão de levar o interlocutor a agir a partir da adesão às ideias propostas; afinal, a propaganda eleitoral e o discurso de posse são convites à ação colaborativa, primeiro do eleitor, e depois do povo brasileiro.

Essa dificuldade decorre ainda do fato de que esta pesquisa se desenvolve em concordância com as teorias críticas de análise do discurso, que objetivam revelar os elos entre linguagem e prática social e que consideram a linguagem, em geral, como prática social, forma de ação sobre o mundo (FAIRCLOUGH, 1997); portanto, desconsidera a possibilidade de um discurso político elaborado sem a intenção de levar a uma ação, ainda que esta seja apenas uma disposição para a ação. De qualquer maneira, é indiscutível a importância da visão de Osakabe (op. cit.), principalmente no que diz respeito ao critério das imagens pressupostas e sua influência na argumentatividade do discurso político. 
Assim, por ter como objeto de análise as metáforas e a linguagem metafórica no discurso de Fernando Collor de Mello, esta pesquisa contempla, principalmente, a persuasão no sentido que lhe conferiu Charaudeau (2005), de ação a ser exercida com base nos deslocamentos emocionais e na possível identificação do auditório com a pessoa do locutor, já que a produção e a interpretação da metáfora pouco dependem da razão. A identidade da metáfora é imprecisa, tendo em vista o fato de que ela ativa os sistemas cognitivos individuais de crenças e valores do interlocutor, num convite à sua participação em um sutil processo de co-construção de significados.

A respeito dessa ativação dos sistemas de crenças e valores de determinado auditório, para que haja a construção de significados comuns entre locutor e interlocutores que conduz à persuasão, expõe-se a seguir a teoria dos modelos mentais, proposta por van Dijk (2008).

\subsection{Modelo mental como base da cognição política: elo entre ideologias e discurso}

Segundo van Dijk (2008), estudar as bases da cognição política implica estudar as representações ou modelos mentais que as pessoas compartilham enquanto atores políticos, sendo tais modelos mentais por ele definidos como interpretação pessoal de um acontecimento ou fato externo que leva em conta crenças, valores, normas, tradições e conhecimentos individuais ou coletivos. $\mathrm{O}$ autor propõe que o elo entre ideologias e discurso seja fornecido pela teoria do modelo mental, conforme se observa:

Um elemento crucial do meu enquadre que falta às outras pesquisas sobre a cognição política é o dos modelos mentais, que servem como a interface necessária entre as cognições políticas socialmente partilhadas, de um lado, e as crenças pessoais, do outro. Esses modelos também servem como as bases cognitivas do discurso político e da ação política, e também relacionam as macroestruturas políticas das representações partilhadas de grupos e instituições com as microestruturas políticas das atividades dos atores políticos. (VAN DIJK, 2008, p. 202)

O autor já definira, em trabalhos anteriores (1997, p. 105), ideologias como "sistemas básicos de cognições sociais fundamentais e como princípios organizadores das atitudes e das representações sociais comuns a membros de grupos particulares", e dizia que, para que elas possam ser associadas a produções discursivas escritas e orais, é necessária uma interface cognitiva que transforme o geral/social no específico/pessoal; as atitudes sociais em opiniões pessoais. Os modelos, como representações mentais de experiências pessoais relativas a 
ações, acontecimentos ou situações particulares, formam a base mental do discurso oral e escrito localizado.

Esses modelos mentais são construídos e modificados por várias manifestações de fala e de escrita a que somos expostos durante nossa socialização, o que implica dizer que o processamento de informações políticas, dentre tantas outras, é frequentemente discursivo, pois a ação e a participação políticas, em grande medida, são realizadas pelo discurso e pela comunicação, conforme indica van Dijk (2008).

Se a formação dos modelos mentais resulta não apenas de cognições sociais, mas também de atividades discursivas, é possível acrescentar que certos grupos como a escola e a mídia, que influenciam a formação de conhecimentos e crenças, também são capazes de controlar, ainda que indiretamente, a formação desses modelos mentais. (AQUINO, 1997) Neste sentido, então, pode-se entender que a produção discursiva de Fernando Collor, veiculada pela mídia, afetasse e transformasse o modelo mental dos eleitores brasileiros, que interpretaram tais manifestações de forma favorável ou desfavorável, aderindo ou não a elas.

De fato, ao se considerarem o contexto e as amostras do corpus relativas à época da eleição de Fernando Collor para a presidência (ANEXOS A e B), pode-se dizer que o referido político, de certa forma, afetou o modelo mental de boa parte de seus interlocutores, pois conseguiu ser eleito presidente. Para isso, contribuiu a construção de sua imagem como “caçador de marajás”, denominação que já o acompanhava desde a década de 80, quando ocupou o cargo de governador de Alagoas e entrou em conflito com funcionários públicos alagoanos que recebiam altos salários. Assumir tal denominação durante a campanha presidencial também teve papel decisivo na eleição, por esta imagem se ajustar às expectativas de moralização e desenvolvimento do país que havia por parte de grande parcela da população brasileira.

Voltando aqui ao critério das imagens pressupostas de Osakabe (1999) citado anteriormente, seria possível dizer que houve, nessa ocasião um bom ajuste entre a imagem que o locutor pressupõe que seu interlocutor faz do referente e a intenção do ato que este locutor visa praticar sobre seu interlocutor. Ou seja, Collor conseguiu captar as expectativas do eleitorado no que se referia à moralização e ao desenvolvimento do país e, a partir dessa constatação, ajustou seu discurso para obter o resultado de persuasão esperado.

Quando, porém, analisam-se as amostras do corpus que correspondem à época que sucedeu ao Impeachment, como a entrevista televisiva concedida ao Programa Livre, de 
agosto de 1998 (ANEXO D), e a entrevista publicada na página eletrônica da revista Istoé Gente concedida em dezembro de 2000 à repórter Neuza Sanches (ANEXO E), ocorre o oposto, uma falta de sintonia entre a intenção discursiva e expectativa do interlocutor, pois, apesar de se candidatar a vários cargos, o então ex-presidente não conseguiu se reeleger, o que sinaliza que não conseguiu o efeito persuasivo pretendido.

Certamente, outras circunstâncias também tiveram influência para que Collor não alcançasse os fins eleitorais propostos, tanto nas eleições de 2000, quando tentou se candidatar prefeito de São Paulo, quanto em 2002, quando se candidatou a governador de Alagoas, principalmente porque seus direitos políticos, cassados por ocasião do Impeachment, só lhe seriam restabelecidos ao final de 2000. Porém, em termos discursivos, numa primeira análise de algumas expressões metafóricas presentes nas amostras do corpus referentes a tais períodos, observa-se que há uma substancial mudança no domínio metafórico fonte escolhido para a construção da identidade de Fernando Collor, que se apresentava então como sofredor (linha 64) e vítima de violência (linhas 93 e 107) no ANEXO D, e “cobra sem veneno”(linha 54), no ANEXO E.

Possivelmente, o emprego de tais termos consistia numa estratégia de persuasão tal que, ao construir uma identidade de sofrimento e fragilidade em relação à violência de seus oponentes, sensibilizasse seu auditório e reconquistasse a credibilidade perdida. Entretanto, não foi isso o que aconteceu. Collor não conseguiu recuperar a confiabilidade, pelo menos não a ponto de se eleger aos cargos aos quais se candidatou nesse período. Ao se estudarem amostras do corpus correspondentes a essa época, sempre observando como fato linguístico as metáforas utilizadas, é razoável referir que a estratégia de criar uma imagem caracterizada pela perda de força não entrou em sintonia com os modelos mentais do eleitorado de Collor, que não aderiu às suas propostas políticas nessa ocasião.

Além de observar a cognição política a partir da teoria dos modelos mentais de van Dijk (2008), relacionar o discurso aos processos sociais, aqui respectivamente representados pelas manifestações discursivas de Fernando Collor e os altos e baixos de sua carreira política, também parece possível se for considerada a proposta de Fairclough (1997), para quem a Análise Crítica do Discurso (ACD) revela os elos entre a linguagem e a prática social. Para este autor, a ACD deve ser utilizada na investigação da mudança, seja ela social ou cultural, pois ela examina as conexões entre as propriedades dos textos linguísticos e a natureza dos processos e relações sociais (ideologias, relações de poder), evidenciando e criticando estas 
conexões, cuja eficiência reside em grande parte no fato de serem opacas ou, pelo menos, pouco transparentes.

Reafirmando esses objetivos, Wodak (2004, p. 225) observa que a ACD tem um interesse particular na relação entre linguagem e poder, tomando como objetos de investigação discursos institucionais, políticos e de gênero social e midiático, com o interesse de "analisar relações estruturais, transparentes ou veladas, de descriminação (sic), poder e controle manifestas na linguagem", pois ela também é um meio de dominação e força social, conceito com o qual concorda a maioria dos analistas críticos do discurso.

Para examinar mais intimamente a conexão entre o discurso de Fernando Collor e o processo social em que ele se insere, com o propósito de torná-la mais transparente, optou-se nesta pesquisa por adotar o Modelo tridimensional de análise de Fairclough, que propõe a descrição linguística, a interpretação das relações entre processos discursivos e texto e a explicação da relação entre os processos discursivos e os sociais, conforme exposto a seguir.

\subsection{Modelo tridimensional de análise de Fairclough}

Fairclough (2001, p.91) afirma que “o discurso é uma prática, não apenas de representação do mundo, mas de significação do mundo, constituindo e construindo o mundo em significado." Este autor propõe um método tridimensional de Análise do Discurso, de que fazem parte a descrição linguística, a interpretação das relações entre os processos discursivos (produtivos e interpretativos) e o texto e, por fim, a explicação da relação entre os processos discursivos e os processos sociais. A principal característica desta abordagem é que a ligação entre o texto e a prática sociocultural é mediada pela prática discursiva. (FAIRCLOUGH, 1997, p. 83)

Esse modelo tridimensional de análise apresenta pontos de contato com os estudos de Halliday que, no início dos anos 1970, já mostrava a importância da relação entre o sistema gramatical e as necessidades sociais e pessoais que a linguagem precisa atender (WODAK, 2004). A abordagem funcional de Halliday (1985) registra três macrofunções linguísticas que atuam nos textos ao mesmo tempo: a ideacional, de representar a experiência, os eventos, as ações, os estados, enfim todos os processos, de maneira simbólica; a interpessoal, da perspectiva de língua como ação, processo de interação social e seus usos para expressar relações sociais e pessoais; e a textual, que se refere aos aspectos semânticos, gramaticais e 
estruturais, constituindo a coerência e a coesão dos textos, cuja seleção significativa está ligada a contextos sociais de interação. (RESENDE e RAMALHO, 2006).

Numa recontextualização desta abordagem, Fairclough (2001) propõe que o discurso contribui para a construção de identidades e de sujeitos sociais, para construir as relações sociais entre as pessoas e para a construção de sistemas de conhecimento e crença, acrescentando que estes efeitos correspondem, respectivamente, a três funções da linguagem: 'identitária', 'relacional' e 'ideacional'. Segundo ele:

A função identitária relaciona-se aos modos pelos quais as identidades sociais são estabelecidas no discurso, a função relacional a como as relações sociais entre os participantes do discurso são representadas e negociadas, a função ideacional aos modos pelos quais os textos significam o mundo e seus processos, entidades e relações. (op. cit., p.92)

Em trabalhos posteriores, Fairclough (2004) articulou essas funções aos conceitos de estilo, gênero e discurso, sugerindo, em lugar das funções, três principais tipos de significados: o significado identificacional, o significado acional e o significado representacional, que atuariam simultaneamente em todo enunciado. $\mathrm{O}$ significado identificacional, ligado a estilos, que se refere à construção e à negociação de identidades no discurso, relaciona-se à função identitária; o significado acional, ligado aos gêneros, que focaliza o texto como modo de (inter)ação em eventos sociais, aproxima-se da função relacional, pois a ação legitima/questiona relações sociais; e o significado representacional, ligado ao discurso, que enfatiza a representação de aspectos do mundo - físico, mental, social - em textos, relaciona-se à função ideacional.

A partir do que propõe Fairclough (2004), e entendendo que essa correspondência pudesse ser mais bem visualizada, propõe-se o quadro a seguir: 


\begin{tabular}{|l|l|l|l|}
\hline Contribuições do discurso & Funções & Conceitos & Significados \\
\hline $\begin{array}{l}\text { Construção de identidades e } \\
\text { sujeitos sociais }\end{array}$ & $\begin{array}{l}\text { Função } \\
\text { Identitária }\end{array}$ & ESTILOS & Significado Identificacional \\
\hline $\begin{array}{l}\text { Construção de relações } \\
\text { sociais entre as pessoas }\end{array}$ & $\begin{array}{l}\text { Função } \\
\text { Relacional }\end{array}$ & GÊNEROS & Significado Acional \\
\hline $\begin{array}{l}\text { Construção de sistemas de } \\
\text { conhecimento e crença }\end{array}$ & $\begin{array}{l}\text { Função } \\
\text { Ideacional }\end{array}$ & DISCURSO & $\begin{array}{l}\text { Significado } \\
\text { Representacional }\end{array}$ \\
\hline
\end{tabular}

Quadro 1. Correspondência entre as Contribuições do discurso, as Funções e os Significados.

No presente trabalho, quando se considera a construção das identidades do locutor, Collor, amigo de quem trabalha, de seu auditório, entre eles os servidores que efetivamente trabalham, e dos adversários, por meio dos termos marajá, corrupto e turistas, na publicidade de campanha (ANEXO A), coloca-se em evidência a função identitária da linguagem e o significado identificacional, conforme se observa no segmento:

(1) ... você POde estar certo ... meu amigo servidor... que eu não vou demitir ninguém que trabalha... agora... marajá ... corrupto e boa vida... esses vão pra rua... mas estes... não são funcionários públicos... estes são turistas... (linhas 17 a 21)

Por outro lado, destacam-se a função relacional e o significado acional da linguagem, quando se considera de que maneira a propaganda de campanha promove a interação entre o locutor e os telespectadores, agindo para legitimar a relação de cumplicidade e aproximação entre o candidato e seus eleitores, e como o discurso de posse (ANEXO B) é planejado para dar continuidade à ideia de que a ação política de Collor é sagrada, portanto, deve ser apoiada. Observe-se, no exemplo seguinte, retirado do ANEXO B, como o uso do verbo jurar e seu complemento a vocês, evidencia o vínculo de dependência que o locutor quer estabelecer com seu auditório e como a expressão altar de minhas convicções recupera a ideia de sacralização das ações do locutor:

(2) Quero, neste instante, jurar a vocês, diante do altar de minhas conviç̧ões, ... (linha 19)

E, por fim, observam-se a função ideacional da linguagem e o seu significado representacional quando, através da análise da linguagem metafórica, procura-se obter 
pistas da visão de mundo de Fernando Collor e de como ele pretende impor esta visão a seus interlocutores, apresentando-se como líder que os conduzirá e solucionará os problemas da nação. As escolhas linguístico-metafóricas presentes nos seguintes exemplos do discurso de posse (ANEXO B) ilustram a tentativa de concretização, própria da metáfora, da ideia de GOVERNAR como CONDUZIR POR UMA ESTRADA, um conceito metafórico que estrutura, no discurso de Collor, a atividade de GOVERNAR, em termos de um diferente domínio de experiência, o de CONDUZIR POR UMA ESTRADA.

A transição democrática se completa neste instante...(linha 2)

(4) Temos compromissos com a justiça social, temos compromissos com o desenvolvimento, com a liberdade e com o progresso que haverá de nortear os rumos deste País, a partir deste 15 de março. (linhas 4 a 6)

... para que nós encontremos, definitivamente, a trilha do crescimento econômico e da justiça social! (linhas 32 e 33)

Nesses exemplos (3), (4) e (5), os termos transição, passagem de um ponto ou estado a outro, rumos, caminho, itinerário, e trilha, pista, rastro, vereda, são desdobramentos do conceito metafórico estruturador GOVERNAR É CONDUZIR POR UMA ESTRADA, denominado metáfora conceptual por Lakoff e Johnson (2002[1980]), em que a conceptualização da complexa ação de GOVERNAR, o domínio alvo, é feita por meio da ação mais concreta de CONDUZIR POR UMA ESTRADA, o domínio fonte. Nos exemplos (4) e (5), a aproximação do locutor em relação a seu auditório é confirmada pelo uso de primeira pessoal do plural em "temos" e "nós", o que reforça a ideia de partilha que o locutor quer propor a seus interlocutores, quanto ao percurso desta ESTRADA até o "crescimento" e a "justiça".

Segundo Fairclough (2001), a metáfora constitui instrumental adequado para a Análise Crítica do Discurso, pois a forma como um domínio particular da experiência é metaforizado representa um dos marcos definidores das práticas discursivas. Como estudioso preocupado em observar a mudança social provocada pela mudança discursiva, ele afirma que mudar a metaforização da realidade constitui aspecto relevante da mudança discursiva com implicações culturais e sociais. Ele cita o exemplo dos trabalhadores de educação que se opõem a utilizar metáforas de bens de consumo ao tratar de educação, evitando caracterizá-la como produto comercializável. O autor observa que algumas metáforas estão tão naturalizadas em uma cultura que as pessoas não conseguem, nem desejam, escapar delas em seu discurso e resistem fortemente a substituí-las, pois, caso isso ocorresse, significaria uma transformação não apenas discursiva, mas no pensamento e na prática dessas esferas. 
O fato de ter estruturado sua manifestação linguística em torno do conceito de que GOVERNAR É CONDUZIR POR UMA ESTRADA pode fornecer pistas sobre a maneira de perceber, pensar e agir do locutor, que se coloca em posição de dominação ao insinuar-se como líder condutor do povo brasileiro. Essa afirmação tem como base as teorias cognitivas sobre a metáfora, segundo as quais o ser humano utiliza o processo metafórico para construir seu conhecimento de mundo, seus pensamentos, emoções e, por consequência, estrutura sua maneira de manifestar-se, comunicar-se, linguisticamente ou não. São teorias relativamente novas, desenvolvidas por estudiosos dos processos cognitivos que descobriram ter a metáfora papel significativo neles. A seguir, apresenta-se um breve percurso desses estudos, ao menos daqueles que mais interessam a esta pesquisa, que deseja observar a linguagem metafórica em suas perspectivas cognitiva, ideológico-cultural e argumentativa, dentro do discurso político.

\subsection{Teorias da metáfora: Aristóteles, Lakoff e Johnson, e Charteris-Black}

Etimologicamente, o termo metáfora deriva da palavra grega metaphorá: junção de dois elementos - meta ("sobre") e pherein ("transporte"). Trata-se de uma palavra tomada em outro sentido; consiste na transposição, que pode ocorrer de modos variados, como se pode observar a partir do que afirma Aristóteles, ao tratar desse fenômeno em sua Arte Poética, por volta de 336 a.C.:

A metáfora é a transposição do nome de uma coisa para outra, transposição
do gênero para a espécie, ou da espécie para o gênero ou de uma espécie
para outra por via de analogia. (...) O que a velhice é para a vida, a tarde o é
para o dia. Diremos, pois, que a tarde é a velhice do dia, e a velhice é a tarde
da vida ou, como Empédocles, o ocaso da vida. (p.274)

Aristóteles também define a metáfora como a capacidade de perceber semelhanças e trata do valor argumentativo dessa figura em sua Arte Retórica, afirmando que sua utilização constitui sempre um processo de enriquecimento, seja por sua função estética ou argumentativa. Em ambos os casos, entretanto, ela irá trazer uma visão de mundo, pelo estereótipo ou pelo contrassenso, confirmando saberes partilhados ou estabelecendo relações inéditas, exercendo evidente persuasão (MOSCA, 1997).

Para Ricoeur (2000), que se preocupou com a maneira como a realidade de uma pessoa é configurada por sua percepção de eventos no mundo, a metáfora é observada não mais em uma visão substitutiva (clássica), mas interativa: o significado literal e o metafórico 
interagem, ou melhor, a metáfora é o produto da interação específica de significados heterogêneos, mas comuns. Não se trata apenas de confrontar objetos diferentes para estabelecer se alguma característica de um pode ser atribuída ao outro, mas da utilização de todo sistema de lugares-comuns, para filtrar ou dispor um outro sistema, gerando, assim, uma nova organização conceitual; emerge, desse modo, a insubstituibilidade cognitiva da metáfora.

Cameron (1999) observa que os inúmeros teóricos e pesquisadores desse tema concordam apenas com um tipo geral de descrição da metáfora como forma de ver uma coisa em termos de alguma outra coisa. Reconhecendo a importância da metáfora como forma de pensamento e de uso da linguagem, essa autora propõe estudos que envolvam a metáfora discursiva, aquela encontrada em situações de vida real, um método empírico de exploração de um uso linguístico imbricado com o social e o cognitivo, proposta adotada na presente pesquisa.

Segundo a teoria cognitivista da metáfora, desenvolvida por Lakoff e Johnson (2002[1980], p.45), “A essência da metáfora é compreender e experienciar uma coisa em termos de outra.” Estes autores afirmam que "nosso sistema conceptual ordinário, em termos do qual não só pensamos, mas também agimos, é fundamentalmente metafórico por natureza." Para eles, a metáfora estrutura ações que realizamos, assim como a maneira pela qual compreendemos o que fazemos; sua presença não se verifica apenas na seleção lexical a que procedemos - está em nosso próprio conceito, em nossos processos de pensamento, compondo um sistema cognitivo que, por sua vez, é baseado em nossas experiências de mundo. Eles afirmam que:

(...) a metáfora é, para a maioria das pessoas, um recurso da imaginação poética e um ornamento retórico - é mais uma questão de linguagem extraordinária do que de linguagem ordinária. (...) usualmente vista como uma característica restrita à linguagem, uma questão mais de palavras do que de pensamento ou ação. (...) Nós descobrimos, ao contrário, que a metáfora está infiltrada na vida cotidiana, não somente na linguagem, mas também no pensamento e na ação. Nosso sistema conceptual ordinário, em termos do qual não só pensamos, mas também agimos, é fundamentalmente metafórico por natureza. (p.45)

Para esses estudiosos, a metáfora implica uma transposição de domínios, ou seja, escolhe-se alguma coisa em um domínio de origem e transpõe-se para outro domínio. Lakoff e Johnson chamam metáfora conceptual o conceito metafórico estruturador de uma atividade cotidiana, que, a princípio, pode ser definido por meio da análise de expressões metafóricas 
utilizadas em determinada atividade discursiva e envolve a compreensão de um domínio da experiência em termos de um domínio diferente de experiência.

O exemplo já clássico utilizado pelos autores é a metáfora conceptual DISCUSSÃO É GUERRA, convencionalmente representado por letras maiúsculas, que não só apresenta desdobramentos em nossa atividade cotidiana em variadas expressões como: "Seus argumentos são indefensáveis.", mas também define o que fazemos quando participamos de uma discussão, planejando estratégias, atacando as posições de nossos adversários e defendendo as nossas e, finalmente, ganhando ou perdendo tal discussão.

Para Lakoff (1987), a metáfora é um importante aspecto imaginativo do raciocínio no que diz respeito à categorização, isto é, tem um papel muito relevante na maneira como construímos significado a partir de nossas experiências e os separamos em categorias, diferenciando-os uns dos outros. Este autor afirma que os modelos metafóricos, mapeamentos de um modelo de imagens em um domínio para uma estrutura correspondente em outro domínio, podem ser um dos tipos de modelo cognitivo que auxilia a categorização, explicando de que forma essa atividade acontece.

Em estudos posteriores, Lakoff e Johnson (1999) propuseram uma teoria cognitiva integrada sobre o raciocínio metafórico na tentativa de explicar melhor como o ser humano conceptualiza juízos subjetivos, tais como importância e similaridade, e experiências subjetivas, tais como desejo e afeição, em termos de outros domínios mais concretos de experiências sensório-motoras, como proximidade e calor. Essa teoria, chamada Teoria Integrada da Metáfora Primária, propõe que metáforas primárias, as metáforas conceptuais em seu estado mais primitivo, são parte do inconsciente cognitivo humano, adquiridas automática e inconscientemente, via processos naturais de aprendizagem neural, principalmente durante nossos primeiros anos de vida.

Neste período, a experiência é indiferenciada, e uma criança aprende a relacionar, por exemplo, a experiência subjetiva da afeição com a experiência sensório-motora do calor quando elas duas acontecem ao mesmo tempo, e a criança sente o calor ao ser abraçada. Mais tarde, essa criança conseguirá diferenciar experiências e será capaz de separar os domínios da 'afeição' dos domínios do 'calor', porém associações do cruzamento desses domínios persistirão em realizações linguísticas como 'um sorriso caloroso', utilizadas por ela no futuro. 
Em outro estudo de interesse para a presente pesquisa, Lakoff (1990) propõe a 'Hipótese da Invariância', segundo a qual afirma que, quando um esquema conceitual básico é utilizado como fonte de uma metáfora, todos os componentes estruturais desse esquema são transferidos para o domínio alvo. Tais componentes podem ou não estar explícitos no discurso, mas o sistema conceitual torna-os potencialmente disponíveis. Tomando-se do discurso político, por exemplo, uma manifestação em que a POLÍTICA fosse metaforizada pelo domínio fonte da GUERRA, um esquema conceitual básico, a ação política descrita poderia ser entendida de forma mais abrangente como se apresentasse combates metafóricos, inimigos metafóricos, vitórias e derrotas metafóricas, mesmo que esses conceitos não estivessem explícitos no discurso.

Caracterizar a POLÍTICA como GUERRA através de metáforas facilita compreender o conceito abstrato da POLÍTICA em termos do conceito mais concreto da GUERRA, por ser este um conceito baseado nas imagens que já temos. Lakoff afirma que boa parte do raciocínio abstrato, senão todo ele, é uma versão metafórica do raciocínio baseado em imagens. A 'Hipótese da Invariância' proposta pelo autor sugere que o raciocínio que envolve conceitos metafóricos como POLÍTICA É GUERRA é fundamentalmente baseado em imagens, porque o domínio fonte desses conceitos, a GUERRA, é estruturado por esquemas de imagens.

São inúmeros os exemplos do corpus, em praticamente todas as amostras, em que se podem identificar declarações de Fernando Collor em que há desdobramentos, correspondências, ou, como preferem os estudiosos de metáforas, os mapeamentos desta metáfora conceptual POLÍTICA É GUERRA, como os seguintes:

(6) ... que lutei tanto em Alagoas... e iniciei uma cruzada... (ANEXO A, linhas 10-11)

(7) ... brasileiros (sic) quem eu devo essa conquista democrática:... (ANEXO B, linha 9)

(8) "Vou finalmente descansar um pouco, retemperar as forças e partir para a luta", confortei-me,... (ANEXO C, linha 81)

(9) (referindo-se a Ulisses Guimarães) O seu comportamento mudaria quando se iniciaram as articulações para garantir a tomada do poder, através de um golpe de mão. (ANEXO C, linhas 339-340)

(10) ... a campanha eleitoral em 1986 a o::governo de Alagoas foi uma campanha de uma violência brutal... que a gente só vê talvez em filme e mesmo assim não acredita... por quê? Porque eu me insurgi exatamente contra esses currais eleitorais... eram currais inexpugnáveis... daqueles coronéis né?... que dominavam aqueles votos... (ANEXO D, linhas 560 a 564) ... em política não existem amigos. Existem aliados. (ANEXO E, linha 67) 
(12) Encerrada a apuração, era preciso ensarilhar as armas do embate eleitoral e buscar a cooperação dos adversários, que sempre respeitei... (ANEXO F, linhas 210-211)

(13) Devo-a (gratidão), também, a todos que, nas diferentes fases do processo naquela Casa, reagiram contra a sucessão de ilegalidades cometidas. Protestaram contra os abusos de que eu estava sendo vítima e lutaram, com as armas do direito e do bom senso, contra o ardiloso massacre que se armou com o uso dos mais condenáveis subterfúgios. (ANEXO F, linhas 1137 a 1141)

Os termos metafóricos em destaque: lutei, cruzada, conquista, luta, tomada do poder, golpe, campanha de uma violência brutal, insurgi, inexpugnáveis, dominavam, aliados, armas do embate, adversários, lutaram, armas, ardiloso massacre e armou, foram tomados do domínio fonte da GUERRA pelo locutor para expressar mais concreta e vivamente sua visão sobre a POLÍTICA, em suas variadas articulações. Essas escolhas linguísticas que Fernando Collor fez indicam que o seu pensamento a respeito da POLÍTICA está estruturado em termos do conceito de GUERRA, mas, principalmente, que sua ação em relação à POLÍTICA também é estruturada dessa forma.

Charteris-Black (2004), estudioso que também se interessa em compreender de que maneira escolhas metafóricas, como as relacionadas ao esquema conceitual básico POLÍTICA É GUERRA, influenciam nosso pensamento, persuadindo-nos de certas maneiras de enxergar o mundo, faz uma adequação contemporânea dos estudos da metáfora às teorias críticas e propõe um modelo de Análise Crítica da Metáfora para justificar escolhas metafóricas particulares em diferentes tipos de discurso, levando a um modelo discursivo de metáfora. Ele argumenta que examinar a influência social da ideologia, da cultura e da história pode proporcionar uma justificativa mais convincente para escolhas metafóricas em contextos discursivos específicos. Este autor acredita que esta abordagem "social" pode ser complementar à visão semântico-cognitiva, que se ocupa de estudar como as metáforas são interpretadas pelos indivíduos.

Esse autor postula que, apesar de muitos estudiosos classificarem as metáforas usando nomenclaturas diferentes, grande parte deles concorda que essa classificação não pode ser feita com um critério linguístico superficial, porque a linguagem metafórica é resultado de processos cognitivos subjacentes que também precisam ser representados. Charteris-Black propõe uma classificação hierárquica em que as metáforas seriam descritas de acordo com seu nível de abstração, partindo do concreto discursivo até atingir um grau máximo de abstração, em metáforas, metáforas conceptuais e chaves conceptuais, o que ajudaria na compreensão da base ideológica da metáfora. Ele diz: 
The analysis I have undertaken supports Lakoff's notion of an inheritance hierarchy in that metaphors can be described by their position in a hierarchy according to the level of abstractness at which they are classified. I have claimed that by analyzing metaphors in a corpus it is possible to understand better the conceptual level of metaphor and how this relaters to underlying ideology. I have claimed that the conceptual level is hierarchically organized into conceptual keys, conceptual metaphors and metaphors. The extent to which an individual will be aware that a particular metaphor is related to a conceptual metaphor, or that a conceptual metaphor is related to a conceptual key, will vary according to individual awareness of metaphor. An awareness of their motivation in socially influent domains of language use improves our understanding of the ideological basis for metaphor choice. (CHARTERIS-BLACK, 2004, p. 244) ${ }^{3}$

Uma aplicação de metáforas encontradas na propaganda de campanha de Fernando Collor (ANEXO A) a partir do modelo hierárquico-cognitivo de metáfora proposto por Charteris-Black, resulta no quadro a seguir:

CHAVE CONCEPTUAL
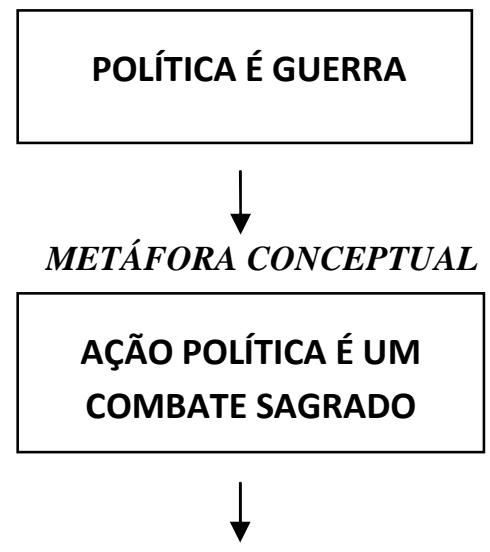

METÁFORA

$$
\begin{aligned}
& \text { que lutei TANto em } \\
& \text { Alagoas... } \\
& \text {...e iniciei uma cruzada... }
\end{aligned}
$$

Quadro 2. Modelo hierárquico-cognitivo de metáfora

\footnotetext{
${ }^{3}$ Tradução livre: A análise que eu empreendi sustenta a noção de Lakoff de herança hierárquica segundo a qual metáforas podem ser descritas por sua posição numa hierarquia de acordo com o nível de abstração em que elas estão classificadas. Tenho afirmado que, ao analisar metáforas num corpus, é possível entender melhor o nível conceptual da metáfora e como isto se relaciona com a ideologia subjacente. Tenho afirmado que o nível conceptual é hierarquicamente organizado em chaves conceptuais, metáforas conceptuais e metáforas. Até que ponto um indivíduo terá consciência de que uma metáfora particular está relacionada a uma metáfora conceptual, ou que uma metáfora conceptual está relacionada a uma chave conceptual vai variar de acordo com a consciência metafórica individual. Uma consciência da sua motivação em domínios do uso de linguagem socialmente influente melhora nosso entendimento da base ideológica para a escolha metafórica.
} 
O autor justifica a utilidade do modelo explicando que as metáforas conceptuais e as chaves conceptuais são níveis de abstração da metáfora discursiva, efetivamente empregada pelo locutor, que permitem identificar modelos de inter-relações que dão conta do significado e da coerência da linguagem metafórica utilizada em discursos particulares. A identificação e a descrição desses níveis propiciam ao analista o acesso a pensamentos que são a base da linguagem, contribuindo para que se compreenda melhor a carga ideológica veiculada pelas metáforas. Mais precisamente, Charteris-Black (2004, p. 244) diz que:

Similarly, conceptual metaphors and conceptual keys are abstract inferences from the linguistic evidence provided by particular metaphors. There is no reality to them other than as working models that further analysis confirms or rejects. The purpose of inferring conceptual metaphors from surface ones is to enable us to identify patterns of interrelationship between metaphors that account for their meaning. Similarly, interrelating conceptual metaphors trough the identification of conceptual keys can assist in accounting for coherence in particular discourses. Identification and description of these conceptual levels enhances our understanding of their role in ideology and contributes to theory building because it provides a point of access into the thoughts that underlie language use. ${ }^{4}$

Charteris-Black afirma que esse modelo descritivo de Análise Crítica da Metáfora de uma estrutura conceptual subjacente implica uma motivação cognitiva para a metáfora. As escolhas metafóricas de um determinado locutor provêm de domínios-fonte geralmente relacionados à sua experiência corporal, mas também à sua experiência social. Ele cita como exemplo a experiência de conflito, coincidentemente também presente no discurso de Fernando Collor, como sendo inerente tanto à experiência física como social. $\mathrm{O}$ autor sugere que a noção de força unifica a experiência de luta - individualmente como no momento do parto, quando lutamos para nascer - com a dimensão social da força - como na competição existente no ambiente de trabalho, quando lutamos por uma posição de destaque profissional.

Chegar aos modelos metafóricos abstratos AÇÃO POLÍTICA É UM COMBATE SAGRADO e POLÍTICA É GUERRA - como conceitos estruturais subjacentes às escolhas

\footnotetext{
${ }^{4}$ Tradução livre: Igualmente, metáforas conceptuais e chaves conceptuais são inferências abstratas da evidência linguística proporcionada por metáforas particulares. Não há realidade para elas senão como modelos funcionais que uma análise adicional confirma ou rejeita. O propósito de inferir metáforas conceptuais daquelas de superfície é permitir-nos identificar modelos de inter-relações entre metáforas que dão conta de seu significado. Igualmente, inter-relacionar metáforas conceptuais através da identificação de chaves conceptuais pode ajudar a dar conta da coerência em discursos particulares. A identificação e a descrição destes níveis conceptuais aumentam nossa compreensão de seu papel na ideologia e contribuem para a construção teórica porque proporcionam um ponto de acesso a pensamentos que são a base do uso da linguagem.
} 
metafóricas discursivas presentes nas manifestações de Fernando Collor quando ele conceptualiza linguisticamente sua ação política - indica que, para ele, a POLÍTICA está estruturada em termos de COMBATE SAGRADO, GUERRA. Para Collor, fazer POLÍTICA é como participar de uma GUERRA que envolve armas, adversários, golpes, lutas, violência, conquistas, massacre, numa experiência unificada pela noção de força, que alternadamente é exercida ou sofrida por ele, dependendo da posição que o locutor ocupa em relação ao poder. Se Collor detém o poder, ele exerce a força. Se lhe falta o poder, é porque o adversário o arrancou à força.

Relembrando a proposta de Fairclough (1997), essa análise parte da identificação e descrição da linguagem metafórica, seguida da interpretação do processo de produção discursiva e da posterior explicação de como a prática discursiva pode ter afetado um processo social, pois entende-se que tal procedimento relaciona o uso de linguagem metafórica como instrumento colaborador significativo na produção de um discurso que, em algumas ocasiões, como a eleição de Fernando Collor de Mello a presidente, permite evidenciar que o auditório foi persuadido a aderir às ideias que o locutor veiculou, o que afetou diretamente o cenário político brasileiro.

Em contrapartida, houve oportunidades em que o discurso de Collor não se mostrou efetivo e não persuadiu o auditório, como ocorre em relação às amostras do corpus que coincidem cronologicamente com a época em que Collor ficou afastado do poder, das quais se destacam os segmentos:

(14) ... invadiu-me um certo sentimento de alívio, como se me encaminhasse para a última batalha, a derradeira volta de uma corrida, o tempo final de uma partida. (linhas 78 a 80)

(8) "Vou finalmente descansar um pouco, retemperar as forças e partir para a luta", confortei-me... (linhas $81,82)$

(15) Percebi ali que o poder escapara mesmo de minhas mãos. (linha 417)

Desse período, são exemplos muito significativos os termos última batalha, derradeira volta de uma corrida, tempo final de uma partida (exemplo 14); retemperar as forças (exemplo 8, recuperado da p. 37); e em particular o segmento Percebi ali que o poder escapara mesmo de minhas mãos (exemplo 15), todos retirados do ANEXO C, constituído pelo relato denominado "Crônica de um golpe", e referentes aos últimos momentos de Fernando Collor no Palácio do Planalto, ao receber o resultado da votação do pedido de Impeachment no Congresso Nacional. Todas essas expressões metafóricas remetem à perda 
de força que Collor experimenta na ocasião e à figurativização do poder que ele vê escaparlhe.

O exemplo 15 traz a frase final do relato "Crônica de um golpe" (ANEXO C): Percebi ali que o poder escapara mesmo de minhas mãos, em que a escolha metafórica que conceptualiza o poder como objeto pertencente a Fernando Collor, mas que agora 'escapa' de suas mãos, retrata a força concretizadora e simplificadora da metáfora, pois torna imagética e simples a situação tão complexa e passível de inúmeras interpretações pela qual o presidente, então impedido, estava passando.

Kövecses (2010) comenta o emprego de metáforas relacionadas a 'controle' que remetem ao ato de segurar algo nas mãos, sugerindo a metáfora conceptual CONTROLAR É SEGURAR (ALGO NAS MÃOS). A possibilidade de manipular diretamente um objeto que se tenha em mãos, fazendo o que se deseja com ele, é a base para essas metáforas. No caso específico do segmento empregado por Collor, é feita a menção à perda de controle, porque a percepção expressa é de que o poder lhe escapa das mãos.

Um outro aspecto de interesse para esta pesquisa, seguindo ainda a proposta de Fairclough, é analisar o emprego de metáforas e linguagem metafórica no processo produtivo do discurso de Fernando Collor quanto à questão da construção da imagem de si que ele apresenta a seus interlocutores em diversas ocasiões. Essa construção não acontece somente pelo que o locutor escolhe dizer, mas também pela maneira como ele o diz, orientando tais escolhas pela avaliação que faz de seu auditório. (AMOSSY, 2005)

Sendo assim, passa-se a examinar mais detidamente no corpus a questão da constituição da identidade de Fernando Collor, pesquisando seus aspectos cognitivos e suas motivações culturais e ideológicas, para melhor compreender de que modo se efetua a interação entre esse locutor e seu auditório, um processo que, segundo Amossy (op. cit.), ocorre por meio da representação, ou imagem, que fazem um do outro. No caso do presente estudo, procura-se compreender de que modo a construção dessa representação produziu no auditório do referido político o efeito apropriado (ou não) para que ele atingisse seus propósitos argumentativos, visto que ele conseguiu se eleger presidente da República e senador, mas não foi eleito para outros cargos a que pleiteou.

Contudo, para que se aprofunde a questão da constituição de identidade de Fernando Collor por meio do exame de suas motivações culturais e ideológicas, por entender-se que tais motivações possam auxiliar a compreender as bases do processo produtivo do discurso desse 
locutor, acredita-se ser necessário melhor definir e diferenciar, na medida do possível, os conceitos de cultura e ideologia, sobre os quais se pode dizer serem separados por uma tênue fronteira semântica, o que se fará a seguir. 


\title{
CAPÍTULO II
}

\section{A METÁFORA E SUAS}

\section{INTER-RELAÇÕES: CULTURA,}

\section{IDEOLOGIA}

\author{
E \\ IDENTIDADES
}




\subsection{Cultura, Ideologia e o "esquema da FORÇA"}

Retomando a proposta de Fairclough (2001) de discurso como construtor de identidades, relações sociais e sistemas de crenças, crê-se que analisar determinados aspectos linguístico-discursivos em manifestações discursivas, especificamente em relação às metáforas e à linguagem metafórica, concorre para desvendar como se constitui, em tais manifestações, a identidade cultural e ideológica do locutor, além de possibilitar que se compreenda como este consegue a adesão de seus interlocutores às ideias que propõe.

Faz-se necessário, primeiramente, abordar os conceitos de cultura e ideologia, em que cabem várias acepções. Segundo Silveira (2004), quando se trata do uso efetivo da língua, exige-se dos estudiosos uma visão multidisciplinar que aborde aspectos cognitivos, discursivos e sociais, a fim de se dar conta de noções difusas como ideologia e cultura. Entre várias possibilidades, a autora define cultura como a memória social, o imaginário simbólico, e o conjunto de normas e valores de um povo, e ainda acrescenta que tratar de cultura implica tratar de identidade e ideologia.

Conforme afirma Kövecses (2006), um estudioso que tem como um de seus objetivos pesquisar a variação metafórica tanto intra como interculturalmente, a cultura pode ser pensada como "um grande conjunto de significados partilhados por um grupo de pessoas" (p. 335), ou ainda como sendo o "entendimento partilhado que as pessoas têm de seu mundo". (p. 93) Ele acresce que esses entendimentos são representações mentais de uma categoria conceptual estruturadas por modelos culturais/cognitivos, ou frames, organizações coerentes da experiência humana.

Ainda de acordo com Kövecses, culturas podem ser diferenciadas pelos diferentes frames que utilizam, pois estes constituem formas divergentes de entendimento sobre a mesma área de experiência. Os frames são ao mesmo tempo de natureza cognitiva e cultural e constituem um enorme e complexo sistema de conhecimento sobre o mundo. Esse autor afirma que, para uma ciência cognitivo-experiencialista, o sentido é definido por frames.

A concepção de frame de Kövecses está bem próxima à teoria do 'modelo mental' de van Dijk (2008), já citada anteriormente, quanto aos aspectos cognitivos, pois as definições referem-se, respectivamente, ao 'entendimento sobre uma área de experiência' ou à 'interface entre cognições políticas e crenças pessoais'. O que difere os conceitos é que van Dijk situa o modelo mental mais no campo pessoal, como sendo a ligação entre ideologia e discurso, 
enquanto que, em Kövecses, o conceito de frames é apresentado de forma indiferenciada, não necessariamente individual, mas com destaque para seu aspecto cultural, pois através dos frames é que se diferenciaria uma cultura de outra.

Em obra anterior, Kövecses (2005) já propunha que, ao pensar a cultura como conjunto de frames partilhados, surge uma relação entre metáfora e cultura dentro da estrutura linguístico-cognitiva, pois, como haviam sugerido Lakoff e Johnson (2002 [1980]), nós não apenas falamos usando metáforas, mas entendemos o mundo por meio delas. Portanto, segundo Kövecses, nosso entendimento partilhado pode ser metafórico, principalmente quando se refere a conceitos abstratos como tempo, emoções, valores morais e instituições sociais e políticas, e as metáforas utilizadas para o entendimento de certos aspectos intangíveis de uma cultura podem se tornar tão importantes e inerentes a ela a ponto de influenciar a maneira pela qual os experimentamos.

De forma mais específica, Kövecses cita que, no discurso político, são frequentes as reformulações de conceitos por meio da utilização de diferentes metáforas por parte dos formadores de opinião, ao participarem de debates sobre assuntos polêmicos como impostos e guerra. (2006, p. 151) Neste sentido, a se considerar o fato de existirem diversas metáforas baseadas em frames para cada questão cultural, quando um locutor escolhe uma metáfora particular para atingir seus objetivos discursivos, acaba por representar a própria ideologia. A esse respeito, Kövecses diz (2006, p.152):

\begin{abstract}
A escolha de um frame metafórico particular pode dividir membros de uma sociedade em subculturas, campos políticos, e assim por diante. Frames metafóricos são escolhidos com base nos objetivos ou ideologia de alguém. Eles também podem ser escolhidos por causa das diferentes consequências que diferentes frames têm. Uma forma significativa de perceber como o papel da metáfora é crucial na cultura é constatar que as metáforas podem se transformar em realidade social. (...) As culturas diferem e podem ser caracterizadas pelas metáforas conceptuais que elas tornam reais em larga escala. 5
\end{abstract}

Para o autor, ser membro de uma cultura significa ter habilidade de produzir e compartilhar significados com outros membros dessa cultura, aliás, ele afirma que uma

\footnotetext{
${ }^{5}$ Tradução livre de: The choice of a particular metaphorical frame may divide members of a society into subcultures, political camps, and so on. Metaphorical frames are chosen on the basis of one's goals and/or ideology. They can also be chosen because of the different consequences that different frames have. A major way in which metaphor's role is crucial in culture is that metaphors can turn into social reality. (...) Cultures differ in and can be characterized by the conceptual metaphors that they make real on a large scale.
} 
grande parte da socialização envolve o aprendizado de como produzir significado em uma cultura, e que o discurso é uma fonte de produção de sentido. Quando, conforme seus objetivos, os membros de uma cultura produzem discursos particulares, com conteúdos que reúnem sentidos particulares e que proporcionam uma perspectiva particularmente significativa para uma cultura, tais discursos podem funcionar como formas de conduta latentes e terem impacto em outros discursos dentro dessa cultura, sendo então considerados como ideologias. (KÖVECSES, 2006)

Essas considerações estão em concordância com o pensamento de Charteris-Black (2004, p. 28), autor que propõe a análise das metáforas como componente central de uma Análise Crítica do Discurso (ACD), porque elas "são usadas persuasivamente para transmitir avaliações e, portanto, constituem parte da ideologia dos textos." Ele também afirma que o potencial pragmático que a metáfora tem de evocar respostas emocionais implica que ela é uma forma de ação verbal através da qual a ideologia é comunicada e existe como fenômeno social.

Tendo em vista os estudos de Kress e Hodge (1993, p. 15), segundo os quais "Ideologia envolve uma apresentação sistematicamente organizada da realidade", CharterisBlack afirma que a metáfora é vital para criar tal apresentação, pois preocupa-se em formar uma visão coerente da realidade. Ele afirma que:

Uma análise crítica dos contextos da metáfora em grandes corpora pode revelar as intenções subjacentes do produtor do texto e, portanto, serve para identificar a natureza de ideologias particulares. $(2004 \text {, p. } 28)^{6}$

Há que se acrescentar ainda que, para esta pesquisa, ao se considerar conjuntamente o significado atribuído por Kösecses (2006, p. 335) de cultura como "conjunto de entendimentos de mundo partilhados", e a anteriormente citada definição proposta por van Dijk de ideologia como "sistema de cognições sociais e princípios organizadores de atitudes" (1997, p. 105), seria possível encontrar uma convergência harmônica entre tais conceitos ao dizer que determinada ideologia pode ser identificada por meio de uma análise das escolhas, entre elas as linguísticas, feitas por um grupo e seus membros, dentro da cultura, para representar uma particular organização da realidade segundo seus objetivos.

\footnotetext{
${ }^{6}$ Tradução livre de : Critical analysis of the contexts of metaphor in large corpora may reveal the underlying intentions of the text producer and therefore serves to identify the nature of particular ideologies.
} 
Retomando Kövecses (2006), ao conceituar discurso como fonte de produção de sentido e do processo de socialização, já que ser membro de uma cultura significa ter habilidade de produzir e compartilhar significados com outros de seus membros, pode-se entender por que Fernando Collor muitas vezes faz escolhas metafóricas com base na cultura nordestina brasileira. Mesmo que, a princípio, considere-se a presença frequente do falar nordestino no discurso de Collor por consequência de seu nascimento em uma família tradicional do nordeste, não se pode desprezar a hipótese de que o objetivo do locutor, ao escolher expressões de apelo mais popular de dada região, seja entrar em sintonia linguística com o povo nordestino, principalmente o de Alagoas, seu reduto eleitoral, partilhando significados com propósitos persuasivos.

Encontram-se abaixo reproduzidos segmentos que atestam essa sintonia entre Collor e a população nordestina. No ANEXO B, Discurso de Posse no Parlatório, encontra-se o exemplo 16, em que o recém-eleito presidente faz questão de ressaltar sua estima e sua ligação com o estado de Alagoas e o nordeste brasileiro em geral, ao referir-se a eles utilizando os possessivos minha e meu e o qualificativo querida. No ANEXO C, o relato "Crônica de um Golpe", encontra-se o exemplo 17, em que ele comenta com orgulho a calma e a valentia da então esposa Rosane Collor durante a saída do Palácio do Planalto, atribuindoas como qualidades próprias dos nordestinos. Ressalte-se, ainda no exemplo 17, o uso do possessivo minha, com o qual o locutor se aproxima da gente do Nordeste.

(16) Volto, também neste momento, o meu pensamento para a minha querida Alagoas, para o meu Nordeste, para todos os recantos deste País, de Norte a Sul,... (linhas 24 e 25)

(17) Permanecia calma. Acho que nela se alevantara a tal valentia sertaneja, própria da minha gente do Nordeste. Rosane carregava uma dignidade da qual me orgulharei sempre. (linhas 69 a 71)

Vilela (2002), outro estudioso dos processos cognitivos metafóricos, afirma que, segundo o paradigma cognitivista experiencial, nossas capacidades simbólicas baseiamse em nossa experiência corporal de movimento, percepção e manipulação, para estruturar e conceptualizar experiências abstratas, sendo a metáfora, em grande medida, responsável por essa operação, pois é "um processo mental em que se estrutura um conceito a partir de outro." (p. 108) Este autor ainda salienta que, além da experiência corporal, as realidades cultural e social também servem de base para o processo de conceptualização. São suas palavras:

O paradigma cognitivo cultural (ou, melhor dito, a antropologia cognitivocultural) considera que os símbolos e as caracterizações através das quais representamos nossa experiência e a realidade não provêm apenas da nossa estrutura corporal ou mental, mas constituem convenções e adaptações a 
uma realidade cultural e social. Uma cultura consiste numa rede de sistemas de significado, concepções e esquemas interpretativos que se geram, aprendem, activam, constroem e se mobilizam em práticas sociais, normas impostas por instituições, incluindo as linguísticas. São jogos culturais que tácita ou explicitamente se instalam em nós, criando disposições habituais, valorizações ou desvalorizações. (op. cit., p. 110)

Levando em consideração essas ideias, é lícito supor que as escolhas linguísticometafóricas que Fernando Collor faz para representar conceptualmente sua realidade reflitam suas experiências culturais e sociais, uma representação que contém indícios do que este locutor valoriza e desvaloriza. Nesse sentido, observa-se que grande parte de suas escolhas metafóricas remete ao que se convencionou chamar de 'esquema de FORÇA', que a maioria dos estudiosos concorda em considerar como um dos esquemas imagéticos básicos na estruturação do sistema conceptual, conforme afirma Kövecses (2003).

Nesse 'esquema de FORÇA', é possível isolar alguns fatores como as entidades que exercem ou sofrem forças, em direção à ação ou inação; e o resultado da interação dessas forças: o fortalecimento, o enfraquecimento ou o equilíbrio entre as entidades, distinções marcadas pela linguagem. (2003, p. 62) O fato de Collor conceptualizar metaforicamente abstrações como o exercício do poder ou a perda dele por meio de conceitos que remetem a FORÇAS pode ser explicado porque tal esquema desenvolve-se em todos os seres humanos conforme eles vão experimentando vários tipos de forças que neles operam e que os afetam.

As forças externas do vento, da tempestade, ou a força que o ser humano imprime ou sente num contato físico, mais leve ou mais brusco, são exemplos dessas FORÇAS concretas, a chamada base experiencial da metáfora, adquirida corporal ou culturalmente, e que servirá para conceptualizar domínios mais abstratos. Essa conceptualização ocorre porque, de alguma forma, um locutor percebe uma conectividade entre dois domínios de experiência, justificando que ele ligue conceptualmente esses domínios. Kövecses exemplifica dizendo que "se nós frequentemente experienciamos raiva como sendo ligada a calor corporal, nós vamos nos sentir justificados em criar e usar a metáfora conceptual RAIVA É UM FLUIDO QUENTE NUM RECIPIENTE.”' (2010, p. 325)

Entretanto, o domínio fonte da FORÇA não é o único a que Collor poderia recorrer para metaforizar suas ideias; portanto, quando Collor opta por esse domínio fonte, entende-se que ele o prioriza entre tantos que poderia escolher, revelando a ideologia que o move. Em exemplos listados a seguir, pode-se observar que Collor considera a sociedade brasileira o foco de onde emanam FORÇAS que asseguraram o processo democrático que o elegeu 
(exemplo 18); ou como o próprio locutor aplicou ou aplicará a FORÇA, ao narrar passagens mais agressivas de sua juventude (exemplo 19), ou prometer 'caçar' (e não apenas 'procurar') os corruptos se eleito (exemplo 20); e como ele sofre a FORÇA, geralmente aplicada de forma violenta por seus adversários, quando, estando afastado do poder, tenta construir uma identidade de vítima injustiçada (exemplo 21).

(18) ... o processo democrático assegurado pelas forças vivas da sociedade brasileira. (linhas 13 e 14 , ANEXO B)

(19) Enfrentei sem hesitar, no braço e inutilmente (porque acabamos todos detidos), nos anos 60, os policiais que...(linhas 112 e 113, ANEXO C) ... a CAça aos maraJÁS... (linha 13, ANEXO A)

(21) vocês todos se lembram que quem comandou... esse processo contra mim... foi o então presidente da câmara dos deputados... chamado Ibsen Pinheiro... que três ou quatro meses após aH é:: eles terem me arrancado da presidência... eles mostraram a sua verdadeira face... ( linhas 90 a 94, ANEXO D)

Interessa, para este estudo, observar o emprego diferenciado que se pode fazer a partir da seleção de linguagem, principalmente a metafórica, referente ao domínio fonte da FORÇA. Enquanto, nas amostras do corpus correspondentes aos tempos de campanha e posse (ANEXOS A e B), Fernando Collor se apresenta no comando da situação, como condutor, lutador, caçador, no ANEXO C, na "Crônica de um golpe", é possível localizar uma seleção metafórica que indica a perda de FORÇA. Apesar de mesclar várias passagens da vida do político em alguns trechos até bastante confusos para o leitor menos inteirado do assunto, grande parte dessa narrativa refere-se ao último dia que o Presidente passou no Palácio do Planalto, 29 de setembro de 1992, aguardando aflito a votação do pedido de Impeachment pelo Congresso Nacional, que terminaria por destituí-lo do cargo de presidente da República. Numa sugestão de que lhe falta FORÇA para prosseguir, o relator cita a prece que fez na saída de seu gabinete antes de se encontrar com os jornalistas que o aguardavam:

... parei um momento para uma breve oração, concluindo quase com um sussurro: "dai-nos forças, meu Deus, para que superemos tudo isso com dignidade e fé.” (linhas 64 a 66, ANEXO C)

Mais adiante, ainda no ANEXO C, no exemplo 14, recuperado da p. 41, o locutor admite sentir certo alívio com a notícia da aprovação do pedido de Impeachment, pois pelo menos ela seria o fim daquela angústia, e indica sua percepção sobre o fim daquela caminhada conceptualizando sua saída do poder, respectivamente, como GUERRA, CORRIDA DE AUTOMÓVEL e PARTIDA DE FUTEBOL, uma seleção metafórica bem ao gosto de quem sempre cultivou uma imagem de esportista saudável. 
(14) ... invadiu-me um certo sentimento de alívio, como se me encaminhasse para a última batalha, a derradeira volta de uma corrida, o tempo final de uma partida. (linhas 78 a 80)

Também do ANEXO C, no exemplo 8, recuperado da p. 37, é possível identificar a ideia de que a parada, o Impeachment, está sendo considerada por ele apenas como um intervalo, para que as FORÇAS perdidas sejam recuperadas com o objetivo de partir novamente para a luta, forma simbólica de definir a retomada do poder.

"Vou finalmente descansar um pouco, retemperar as forças e partir para a luta", confortei-me... (linhas 81, 82)

A valorização da FORÇA, seja ela positiva e indicativa de entusiasmo, energia, potência, vigor, vitalidade, quando se refere à sua identidade, à sua maneira enérgica de enfrentar dificuldades; seja ela negativa, aludindo a coação, violência e truculência, quando exercida por seus adversários ou quando ele perde o poder, é uma constante nas escolhas metafórico-discursivas de Collor. Ele expressa o exercício de poder como empenho físico, e conceptualiza a oposição dos adversários, e a consequente perda de poder, como se lhe estivessem aplicando intenso sofrimento físico.

Fica claro, no exemplo 23, segmento do ANEXO F, o discurso de posse como senador da República quando Collor retoma sua carreira política, que ele quer dar por encerrada essa sofrida fase de ostracismo. Essa manifestação discursiva marca seu retorno ao poder e nela o político retoma termos metafóricos que o apresentam como vítima de violência, mas para citar que o sofrimento serviu-lhe como aprendizagem e o fortaleceu. Essa recuperação da FORÇA, por meio da volta ao poder, ocorre como consequência de sofrimentos impostos metaforizados como mossas, marcas deixadas por pancadas, e cicatrizes, mas que trouxeram proveitosas lições:

\footnotetext{
... os episódios que aqui vou rememorar obrigaram-me a padecer calado e causaram mossas na minha alma e cicatrizes no meu coração. Se o sofrimento e as injustiças provocam dor e amargura, podem também nos trazer proveitosas lições. (linhas 3 a 6 )
}

Tal constância do uso da simbologia da FORÇA, principalmente na construção de sua identidade e na expressão de seu modo de governar e enfrentar adversidades, revela uma visão de mundo que privilegia o exercício dinâmico e enérgico da FORÇA, o que o coloca mais como quem exerce autoridade com firmeza próxima da força física, mais impetuosa do que racionalmente, mais próximo da emoção e da paixão do que da razão.

No decorrer da entrevista ao Programa Livre, transcrita no ANEXO D, Collor afirma: 
(24) ... o que eu sei que tenho é o seguinte... é o que muitos de vocês têm... eu não sei fazer nada na minha vida que não seja com paixão... com ardor e ((risos e gritos do auditório)) com vontade ((risos e gritos do auditório)) não não a paixão piegas ((risos)) não... não cês estão entendendo... não é essa paixão não é essa paixão piegas paixão piegas é uma paixão no sentido de me dedicar inTEgralmente àquilo que eu tô fazendo... (linhas 333 a 339)

Essa disposição mais emocional admitida por Fernando Collor pode ser uma das razões de ele frequentemente utilizar-se de linguagem metafórica, pois, como afirma Kövecses (2003), a linguagem emocional é amplamente metafórica em diversos idiomas, a fim de captar a variedade e intangibilidade das experiências emocionais, únicas para cada ser humano. Ele acrescenta ainda que, metodologicamente, essa linguagem é importante para desvendar essas experiências, não apenas por refleti-las, mas também por criá-las.

Nessa mesma direção, Vilela (2002, p. 111), ao teorizar sobre as influências culturais e sociais da expressão de emoções, diz que “o indivíduo é o 'locus' do emocional, mas é o envolvimento social que determina que emoções se exprimem ou se silenciam”. (p.111). Ele também crê que as emoções criam disposições para comportamentos e atuações, como afirma no segmento:

As emoções não são apenas sentimento, mas também disposições episódicas para comportamentos, atuações, respostas ou reações relativamente a uma norma social. Há emoções hipervalorizadas, hipercognitivizadas. É o modelo cultural e o modelo cognitivo a interpenetrarem-se. A intercompreensão só é possível porque partilhamos, numa comunidade, os mesmos esquemas. (op. cit., p. 11)

Em outra perspectiva, ao produzir um discurso em que é vital a aquiescência do interlocutor, como é o político, em que tudo o que é dito é pensado com o objetivo da persuasão, Collor intui que suas escolhas serão bem entendidas e aceitas por seus interlocutores, principalmente pelo eleitorado nordestino, que valoriza a FORÇA como qualidade positiva de um governante, provavelmente uma herança do coronelismo na região. Neste sistema de poder paralelo, definido como uma complexa rede de relações que permeia todos os níveis de atuação política e que não ocorreu exclusivamente no nordeste, os "coronéis", ou chefes políticos, exerciam domínio econômico e social por meio de práticas que remetiam a autoritarismo e impunidade. (CARVALHO, 1997)

Acrescente-se a isso o fato de o nordestino ser comumente caracterizado como homem 'forte' por enfrentar condições climáticas adversas como a seca e suas consequências na agricultura e pecuária e, ainda assim, resistir, para que se possa justificar mais completamente a valorização da FORÇA como qualidade positiva do povo do nordeste. Consciente dessa 
valorização, um locutor que pretenda influenciar os julgamentos de seus interlocutores dará preferência a escolhas linguísticas por estes valorizadas. Ao estudar mais detalhadamente a ocorrência da metáfora no discurso, principalmente a metáfora nova ou pouco convencional, Kövecses (2010) observa:

(...) em geral, o destinatário exerce um papel em nosso modo de selecionar itens linguísticos para nossos propósitos particulares no discurso. Mais geralmente, uma parte do que nós sabemos sobre o destinatário com toda probabilidade tem papel importante na seleção da metáfora. (p. 295) ${ }^{7}$

A seleção metafórica no discurso de Collor certamente tem uma base cultural e ideológica, mas sem dúvida leva em conta seu interlocutor, aqui representado pelo povo nordestino, seu eleitorado mais fiel. Como locutor consciente, o político seleciona itens linguísticos que sejam valorizados culturalmente por seus interlocutores, pois essa sintonia linguística pode fazê-lo alcançar mais facilmente seu objetivo retórico de exercer o poder político como representante da população.

Essa relação entre locutor e interlocutor, ou entre o orador e seu auditório como os denomina Amossy (2005, p. 125), será examinada mais detidamente a seguir, principalmente por conta de sua importância na construção da imagem ou identidade do locutor, sempre orientada no sentido de causar 'boa impressão' e efetiva persuasão ao auditório a que se dirige. Cabe ressaltar que, para esta pesquisa, foram considerados coincidentes os termos identidade, adotado por Fairclough (2001) ao dizer que o discurso contribui para a construção de 'identidades sociais' e 'posições de sujeito', e imagem de si, construída e reconstruída discursivamente pelo locutor, proposta de Amossy (2005).

\subsection{O papel da metáfora na construção de identidades e na transmissão de ideologias}

A relação entre o locutor e seu auditório, além das circunstâncias em que tal relação ocorre, é objeto de observação de diferentes estudos discursivos, em especial aqueles que se ocupam da argumentação. A esse respeito, Amossy (2005) afirma que "a interação entre o orador e seu auditório se efetua necessariamente por meio da imagem que fazem um do

\footnotetext{
${ }^{7}$ Tradução livre de: (...) in general, the addressee plays a role in how we select linguistic items for our particular purposes in the discourse. (...) More generally, a part of what we know about the addressee in all probability plays a role in the selection of the metaphor. (p. 295)
} 
outro”. E 'imagem' aqui significa a representação, as ideias e as reações que ambos apresentam naquela situação única. A avaliação que um locutor faz de seus interlocutores o orienta a escolher suas estratégias discursivas e a moldar sua imagem, para produzir em seu auditório a impressão apropriada às circunstâncias. Essa autora acrescenta ainda que a eficácia de um discurso depende da autoridade de que goza o locutor entre seus interlocutores. (p. 124)

Em concordância com esses conceitos, acredita-se que Fernando Collor tenha levado em consideração as características de seu auditório todas as vezes em que se dirigiu a ele, seja por meio de propaganda eleitoral, relato, discursos de posse ou entrevista, na tentativa de construir uma imagem que produzisse impressão positiva junto a seus interlocutores, contribuindo para o êxito em seu propósito retórico. Ainda sobre este tema, Amossy diz:

O orador constrói sua própria imagem em função da imagem que ele faz de seu auditório, isto é, das representações do orador confiável e competente que ele crê ser as do público.(...) No momento em que toma a palavra, o orador faz uma ideia de seu auditório e da maneira pela qual será percebido; avalia o impacto sobre seu discurso atual e trabalha para confirmar sua imagem, para reelaborá-la ou transformá-la e produzir uma impressão conforme às exigências de seu projeto argumentativo. (op.cit., p. 125)

Em se tratando de discurso argumentativo, condição própria do discurso político e comum a todas as amostras do corpus estudado, Perelman e Tyteca (2005 [1958], p. 20) afirmam que, "para que uma argumentação se desenvolva, é preciso que aqueles a quem ela se destina lhe prestem alguma atenção", portanto o locutor precisa apresentar-se de forma a causar uma impressão positiva em seu auditório e, consequentemente, a cativá-lo. Como auditório e circunstâncias variam constantemente, o locutor (assim chamado em oposição ao termo orador porque aqui estão sendo consideradas tanto manifestações faladas quanto escritas) precisa desenvolver a habilidade de interpretar, a cada manifestação, que imagem de si apresentar para conseguir a adesão de seu público.

É preciso acrescentar que a construção da imagem do locutor não acontece somente pelo que ele diz a seu respeito, mas também pela forma como ele diz. Amossy (2005, p. 127) aponta que "É o conjunto das características que se relacionam à pessoa do orador e a situação na qual esses traços se manifestam que permitem construir sua imagem." Além disso, a construção e reconstrução da imagem acontecem com a ajuda de modelos culturais, esquemas pré-existentes a que os novos dados se integram.

Para este estudo, é significativo observar como Fernando Collor constrói e reconstrói sua imagem por meio da seleção metafórica que utiliza em seu discurso, conforme seus 
objetivos argumentativos, pois o corpus analisado é constituído de amostras representativas de diversas fases da carreira desse político. O conjunto dessas manifestações discursivas reflete a alternância de sua posição em relação ao poder, ora exercendo-o, ora tentando recuperá-lo, portanto apresenta a construção de diversas identidades, cuja análise permite inferir as diferentes avaliações que o locutor fez de seu auditório e do contexto discursivo, além de ajudar a elucidar o sucesso ou fracasso de seu projeto argumentativo.

Para compreender melhor o processo de construção de identidade que Collor desenvolveu por meio da análise das metáforas que ele empregou em seu discurso, será preciso, além de examinar o contexto em que esse discurso foi produzido, estabelecer a relação entre a metáfora discursiva e a metáfora conceptual (Cf. p. 35). Em razão de, em geral, a metáfora discursiva ser o desdobramento de uma metáfora primária, resultado de processos cognitivos inconscientes que dão estrutura a nosso pensamento (LAKOFF e JOHNSON, 1999), é possível relacionar termos metafóricos encontrados nas amostras do corpus a um determinado conceito estruturador, ou metáfora conceptual, e, através deste, vislumbrar a ideologia subjacente.

Cabe ainda uma vez relembrar que o conceito de ideologia aqui adotado é o proposto por van Dijk (1997, p. 105), para quem:

As ideologias são definidas como sistemas básicos de cognições sociais fundamentais e como princípios organizadores das atitudes e das representações sociais comuns a membros de grupos particulares. Desta forma, controlam indiretamente as representações mentais (modelos) que formam a base interpretativa e a "inserção" contextual do discurso e respectivas estruturas.

O estudo da construção da identidade ou imagem de si no discurso de Fernando Collor, como de qualquer outro locutor, exige que se conheça o contexto cultural da sua produção discursiva. A importância deste conhecimento é reconhecida por Goodwin e Duranti (1992) ao dizerem que um evento não pode ser adequadamente entendido, interpretado ou descrito, a menos que se considerem, para além dele, outros fenômenos em que este evento está inserido, tais como cenário cultural, situações de fala, suposições contextuais partilhadas.

Delineando de forma geral o contexto em que Fernando Collor pode ser situado como locutor, é relevante levar em consideração a ideologia que estrutura os modelos mentais desse político: trata-se de um sistema socialmente adquirido de princípios organizadores de atitudes que ele procura transmitir e que se constituiu em sua vivência como indivíduo que já nasceu membro de uma tradicional e poderosa família de empresários da comunicação e políticos de 
atuação nacional. Seu avô materno, Lindolfo Collor, e o pai, Arnon Afonso de Farias Mello, destacaram-se por exercer cargos políticos de realce inclusive no âmbito federal. A carreira política do pai, Arnon de Mello, que se desenvolveu entre as cidades de Maceió, Rio de Janeiro e Brasília, teve influência até na vida acadêmica de Fernando Collor que, nascido no Rio de Janeiro, obteve seu diploma universitário em Brasília.

Antes de se tornar presidente, Fernando Collor de Mello foi prefeito nomeado de Maceió, deputado federal e governador de Alagoas, época em que se tornou conhecido como "Caçador de Marajás", denominação metafórica que o acompanhou mais tarde na campanha à Presidência da República, por ter empreendido um combate a alguns funcionários públicos que ganhavam altos salários. A consecução de vitórias políticas, como a eleição para Presidência da República em 1990, é indicativa de que, nessas ocasiões, ele obteve sucesso em persuadir seu auditório ao articular ideologia, base de um sistema de crenças compartilhadas pelo grupo social acostumado a situações de poder ao qual pertence, com a produção e a partilha de sentido em seu discurso.

Ao examinar a transcrição da propaganda de campanha (ANEXO A), pode-se observar a construção de três identidades distintas: a do locutor, o político Fernando Collor de Mello, a do grupo de adversários corruptos que ele pretende enfrentar e a do auditório - este último caracterizado como "amigo" e "trabalhador", em oposição aos funcionários públicos corruptos. As duas primeiras identidades, de Collor e dos corruptos, são as mais vivamente caracterizadas com linguagem metafórica, como se pode verificar nos exemplos a seguir:

(25) ... foi para acabar com esta pouca vergonha... minha gente... que lutei TANto em Alagoas... e iniciei uma cruzada que chegou ao Brasil inTEIro... a CAça aos maraJÁS...(linhas 10 a 13)

(1) ... você POde estar certo ... meu amigo servidor... que eu não vou demitir ninguém que trabalha... agora... marajá ... corrupto e boa vida... esses vão pra rua... mas estes... não são funcionários públicos... estes são turistas... (linhas 17 a 21)

No exemplo 25, o termo cruzada, que tem por definição no Novo Dicionário Aurélio (FERREIRA, 1975): "Expedição militar de caráter religioso que se fazia na Idade Média contra hereges ou infiéis.", define metaforicamente a trajetória política de Collor até aquele momento, evocando o domínio da GUERRA. Entretanto, não se trata de uma guerra qualquer, mas um COMBATE SAGRADO, interpretação que o componente semântico religioso do termo cruzada autoriza. Assim sendo, poder-se-ia definir como POLÍTICA É UM COMBATE SAGRADO um possível conceito metafórico estruturador, ou metáfora conceptual, que se refere à identidade desse político. 
Enfatizando a sugestão de FORÇA e belicosidade do termo cruzada, localiza-se, no mesmo exemplo 25, outro desdobramento de POLÍTICA É UM COMBATE SAGRADO. Trata-se do verbo lutei, também metafórico, visto que, certamente, não houve enfrentamento físico entre Collor e seus oponentes. Esta luta a que o candidato se refere aconteceu à época em que foi eleito governador do estado de Alagoas, em 1986, durante a qual implantou um estilo polêmico de governo que pretendia sanear e moralizar a administração pública. Vem desse período a denominação "caçador de marajás" que, no corpus estudado, vem representada pela expressão caça aos marajás, presente neste mesmo exemplo.

A expressão metafórica caça aos marajás remete tanto ao locutor (caça/caçador) quanto a seus oponentes (os marajás). O termo caça acrescenta à ideia de COMBATE o sentido da busca, da perseguição a criminosos ou animais, além de constituir uma metáfora gramatical, ou seja, o uso de um recurso gramatical para expressar uma função que não lhe é própria. A função primordial, de designar ações, do verbo caçar aqui foi desempenhada por caça, que não seria literalmente um substantivo, cuja função principal seria nomear, mas uma metáfora do verbo caçar. $^{8}$

Na mesma expressão, o termo marajás é usado para caracterizar os adversários de Fernando Collor, funcionários públicos corruptos que ocupam cargos com altos salários, o alvo da cruzada moralizadora do orador. No exemplo 1, retomado da página 32, observa-se a caracterização dos 'corruptos', daqueles que devem ser combatidos, por termos como marajá, boa vida e turistas, evocando, no imaginário dos interlocutores, as facilidades e privilégios de quem tem uma posição de destaque, já que marajá significa 'grande rei' e é o título dos príncipes ou potentados da Índia (FERREIRA, 1975), que, imagina-se, só passeiam e não precisam trabalhar, diferentemente daqueles cidadãos comuns, "professores" e "médicos", que compõem o auditório a quem Collor se dirige, como ocorre no segmento:

(26) (...) com você professora professor médica médico que educa os nossos filhos que toma conta da sa-úde dos nossos filhos e não é reconhecido com um salário DIGno...(linhas 1 a 3)

Dessa forma, são construídas três identidades distintas: a primeira é a do locutor, um guerreiro combativo, que já lutou e promete travar um combate sagrado enfrentando os

\footnotetext{
${ }^{8}$ A respeito do conceito de metáfora gramatical, Sardinha (2007, p. 45) afirma que este é "um termo usado na linguística sistêmico-funcional em referência ao uso de um recurso gramatical para exprimir uma função que não lhe é intrínseca." O exemplo que o autor dá é o uso de um substantivo em lugar de um verbo, como em 'sua mudança' em vez de 'ele mudou', no qual a função original de designar ações do verbo 'mudar' passou a ser exercida por um substantivo, cuja função original seria nomear coisas, o termo 'mudança'. Essa passagem, chamada nominalização, é um processo metafórico, pois o substantivo 'mudança' não é literalmente um substantivo, mas uma metáfora do verbo 'mudar'.
} 
privilegiados corruptos, os denominados marajás (aqui representando a segunda identidade), em defesa dos injustiçados servidores públicos, que fazem parte do auditório, a terceira identidade. Destaca-se ainda a inclusão do possessivo nossos referindo-se tanto aos filhos dos interlocutores quanto aos filhos do próprio Fernando Collor, como forma de aproximação e partilha de significado entre locutor e auditório. Além dessas três identidades, ainda é possível vislumbrar a construção de uma quarta identidade, que também será combatida, os poderosos, numa tentativa quase imperceptível do locutor de se fazer desvincular dos políticos mais tradicionais e colocar-se mais ao lado do brasileiro trabalhador:

... será que é justo um apadrinhado dos poderosos ganhar até cinQUENta salários para ficar sentado no seu TROno de maraJÁ... (linhas 6 a 8)

Utilizando-se da expressão apadrinhado dos poderosos, o locutor vincula os funcionários corruptos a supostos padrinhos poderosos que protegeriam seus privilégios. $\mathrm{O}$ termo trono, cujo significado literal é "sólido elevado em que os soberanos se assentam nas ocasiões solenes" (FERREIRA, 1975), é uma metáfora do lugar privilegiado e seguro que estes corruptos ocupam, evocando sua situação de poder. Identificando estes apadrinhados como adversários, que devem ser caçados e combatidos, o locutor constrói para si uma imagem positiva, contrária à corrupção, de alguém que vai combatê-la fortemente, como se exercesse um dever sagrado.

O vídeo da referida propaganda, que também faz parte do corpus analisado, possibilita observar a tentativa de confirmar esta identidade de força e combatividade por parte de Collor, pois sua postura é altiva, séria e enérgica, sua dicção é relativamente acelerada, mas com pronúncia bem articulada, sem hesitações, o que poderia ser caracterizado como um 'falar forte', denominação utilizada por Charaudeau (2008, p.171). Este autor afirma que, embora os julgamentos sobre a vocalidade sejam culturais, o "falar forte" é percebido em todos os lugares como o oposto de "falar frouxo", construindo um ethos, ou, como diz Amossy (2005), uma imagem de si, de líder político poderoso e combativo.

No discurso de posse no Parlatório, reproduzido no ANEXO B e do qual só foi obtida uma transcrição disponível na página eletrônica pessoal de Fernando Collor que pode ser acessada pelo link http://www.collor.com/discursos1990_002.asp, pode-se dizer que o tom é mais brando, mesmo porque, a ocasião da posse como presidente eleito é uma celebração em que este prefere caracterizar seus interlocutores como "amigos" e, mais figurativamente, como “descamisados" e "pés descalços", numa alusão à precariedade das condições sociais do povo brasileiro a quem dirige sua fala, como se pode observar nos exemplos: 
Minha gente amiga do Brasil, ...(linha 1)

(29) ...voltar o melhor do meu pensamento e a maior das minhas preocupações para a imensa maioria de brasileiros ( sic) quem eu devo esta conquista democrática: aos descamisados, aos pés descalços, àqueles que querem justiça social no País, para poder viver condignamente.(linhas 8 a 11)

Cabe ainda observar que Collor recuperou o termo metafórico 'descamisados' do peronismo, movimento político de caráter popular, porém autoritário ao reprimir manifestações contrárias, ocorrido na Argentina entre os anos de 1945 a 1955. Eram figuras centrais desse movimento o general Juan Domingo Perón e sua esposa Eva Perón, respectivamente representados como 'pai' e 'mãe' dos 'descamisados', numa referência simbólica a sua total dedicação à causa dos mais humildes. O termo, que genericamente significava povo ou massa, no imaginário peronista era característico do amigo do líder, aquele que arregaçava as mangas e realizava o trabalho necessário ao desenvolvimento do país. (SANTOS, 2001, p. 166)

Parece que muito desse significado é recuperado no 'descamisados' de Collor, ao referir-se à imensa maioria dos brasileiros a quem ele credita a conquista democrática de sua eleição à presidência, um exemplo de como a metáfora pode exercer a função de proporcionar coerência intertextual a uma variedade de discursos em diferentes períodos históricos. Segundo Kovecses (2010), essa coerência é alcançada quando se herda e se usa uma metáfora particular em discursos de épocas diferentes, numa espécie de reciclagem linguística.

Tentativas de aproximação em relação ao auditório, numa sugestão de igualdade e companheirismo, ainda podem ser verificadas em outros segmentos da mesma amostra do corpus (ANEXO B), em que se localiza a primeira pessoal do plural, o pronome inclusivo “nós”, ou quando o recém-eleito presidente coloca-se 'espacialmente' próximo ao povo:

Todos nós temos compromissos...(linha 4)

... ao lado do povo brasileiro, da sociaedade ( $s i c$ ) civil organizada, ...(linhas 21 e 22)

É preciso ressaltar que este discurso de posse não é o proferido no Congresso Nacional diante de senadores e deputados depois da assinatura do termo de posse, mas um similar, só que mais curto e mais informal, feito já no Palácio do Planalto, após a subida da rampa e a colocação da faixa presidencial, no Parlatório, uma espécie de construção externa ao palácio, em que os políticos se colocam numa posição de destaque perante o público a que se dirigem durante as solenidades oficiais. Neste discurso de posse, não há, como na propaganda de campanha, a caracterização dos "antagonistas" corruptos que devem ser enfrentados. Mas 
ainda permanece a ideia de POLÍTICA É UM COMBATE SAGRADO, portanto, autorizado por Deus, e da "sacralização" da ação política em termos metafóricos como: ... uma luta que incandesceu este País, ...(linha 12)

(33) ... e o processo democrático assegurado pelas forças vivas da sociedade brasileira.(linhas 13 e 14)

(34) ... democracia tão duramente conquistada.(linha 4)

(35) ... juro a vocês, diante do altar de minhas convicções, ...(linha 21)

Os termos luta, na caracterização da campanha, forças, que alude à dificuldade suplantada para assegurar o processo democrático, e conquistada, sugestivo de que a democracia foi conseguida com grande esforço, são desdobramentos da ideia de COMBATE, enquanto o termo altar, repetido mais uma vez logo em seguida, indica que as convicções de Fernando Collor ocupam um lugar SAGRADO.

Todas essas considerações levam a inferir que essas manifestações discursivas de Fernando Collor veicularam uma ideologia que valoriza a FORÇA e a combatividade, além da sacralização das ações, o que equivale dizer que suas causas são nobres, portanto, são justificados quaisquer meios que ele utilizará para atingir seus objetivos. Tais conceitos são expressos, principalmente, pelas metáforas contidas nos termos lutei/luta, cruzada, caça aos marajás, forças, conquistada e altar destas amostras. Entende-se que a ideologia veiculada por meio deles persuadiu o eleitorado, tendo em vista o resultado positivo alcançado pelo candidato às eleições presidenciais e sua grande popularidade no início de mandato.

Já nas manifestações que correspondem a seu exílio político, ANEXOS C, D e E, e até mesmo no seu discurso de posse como senador em março de 2007 (ANEXO F), Fernando Collor se apresenta como injustiçado e violentado por seus adversários, construindo uma identidade que, a se considerar seu afastamento do poder, não foi bem acolhida por seus interlocutores. São vários os exemplos em que se pode destacar a linguagem metafórica empregada na caracterização de mártir e sofredor indefeso, a quem os adversários políticos truculentos sempre infligem golpes e agressões, deflagrando uma verdadeira guerra política. Destacam-se, entre eles:

(36) Fiquei só. Enquanto no Congresso a traição se manifestava e o golpe se consolidava, no meu gabinete nada se ouvia. (ANEXO C, linhas 23 a 25)

(37) Nem deixaria de enfrentar aqueles tolos que tentavam dar legitimidade a um ato de força. (ANEXO C, linhas 120-121) 
...e se agora posso relembrar aqueles momentos com o distanciamento do tempo, é porque a vitória, no final, seria minha. Uma vitória contra todas as manobras engendradas e deflagradas em praticamente todo o território nacional pelas mesmas forças retrógradas que mantêm o Brasil neste anacronismo cruel,... (ANEXO C, linhas 122 a 126)

Nos exemplos 36 e 37, fica patente a conceptualização do Impeachment, ato legítimo democraticamente decidido pelo Congresso Nacional por meio do voto dos parlamentares, como ato violento sofrido pelo locutor por conta dos termos golpe e ato de força. No exemplo 38, a linguagem metafórica remete ao domínio da GUERRA, constituindo um desdobramento da metáfora conceptual POLÍTICA É GUERRA, como fica claro pelo emprego de termos como vitória, com sentido positivo referindo-se ao próprio Collor, manobras engendradas $e$ deflagradas e forças retrógradas, estes últimos com sentido pejorativo, referindo-se às supostas atitudes desleais dos adversários.

É apropriado observar que quando a FORÇA é exercida pelos adversários sobre o locutor ela tem uma conotação negativa. No exemplo seguinte, do mesmo ANEXO C, o termo metafórico marionetes é usado para caracterizar os manifestantes que o aguardavam fora do Palácio, agindo, segundo a imagem simbólica que Collor lhes atribui, por consequência da FORÇA negativa de outros. Essa caracterização é reforçada pelo termo seguinte massa de manobra, conhecida qualificação metafórica de grupo que age sem consciência, guiado por ideologia alheia, um cuidado do locutor que impossibilita culpar o povo, seus eleitores, pelas próprias atitudes.

observei, através da vidraça, as figuras tristes de manifestantes que agiam como marionetes sem vontade própria, massa de manobra fiéis (sic) à velha máxima de mudar algo, qualquer coisa, para não mudar coisa alguma. (linhas 128 a 130)

No ANEXO D, uma entrevista concedida em 1997 a um programa em que o auditório era composto basicamente por adolescentes, Fernando Collor também se apresenta como vítima de adversários violentos e desonestos, na tentativa de reconstruir sua imagem política perante o público jovem. A considerar-se que na transcrição da entrevista existem várias manifestações de desagrado por parte da platéia, e que Collor se reelegeria a um cargo público apenas em 2006, a tentativa foi frustrada. São exemplos dessa amostra do corpus:

(40) veja que... eu me apresento hoje diante...diante de todos vocês... tendo sido... o homem público... mais investigado desse país... o mais humilhado o mais xingado o mais achincalhado o mais execrado... e seguramente o mais investigado... o último homem público que sofreu alguma coisa parecida... em termos de:: de::... investigação... foi o doutor Getúlio Vargas... em 1950... e que lamentavelmente não suporTOU... aquela pressão e deu fim a sua própria vida...(linhas 61 a 67)

(41) e não que... meia dúzia de gatos pingados... lá no Congresso Nacional... se arvorem no direito de em nome de 35 milhões de eleitores... de fazerem o que fizeram...(linhas 85 a 87) 
(42) Eles... os anões do orçamento... eles sim... estavam assaltando o tesouro nacional... eles sim... estavam fazendo as ...é as diabruras e travessuras que todos nós conhecemos... e se eles me arrancaram da presidência... é porque minha gente... seguramente eu não era um deles... e não estava fazendo o jogo deles (linhas 91 a 95)

(43) ... foi uma violência atrás de outra porque não me foi dado direito de defesa em nenhum instante não me foi dado ah: oportunidade de poder falar... dentro ((risada)) dentro do processo... de modo que as coisas foram acontecendo assim de uma forma ah:... violenta... e ah: ah ah inclusive...(linhas 106 a 110)

(44) ... importante é que seja dado oportunidade...(sic) ao povo brasileiro de fazer o seu juízo dentro de um ambiente de razoável tranqüilidade... (sic) sem que haja um clima de emoção... transbordando pelas ruas... de modo a dizer... esse fulano aqui é é culpado... temos que crucificá-lo ele é o causador de tudo e tal... (linhas 144 a 148)

Os termos sofreu (exemplo 40), violência e violenta (exemplo 43) e crucificá-lo (exemplo 44) retratam a imagem de sofrimento físico a que o locutor diz ter sido submetido pelos adversários. No exemplo 40, Collor inclusive se compara a Getúlio Vargas, também pressionado por seus oponentes, deixando subentendida a ideia de ser mais forte que o presidente suicida, visto que escolheu reagir de maneira diferente à pressão exercida. A caracterização dos adversários como meia dúzia de gatos pingados (exemplo 40), anões do orçamento que assaltam o tesouro, fazem diabruras e travessuras, arrancam-no da presidência (exemplo 42) e querem crucificá-lo (exemplo 44) revelam a tentativa de construir uma imagem negativa de seus antagonistas, atribuindo-lhes desonestidade e uso da violência contra o locutor.

Em dezembro de 2000, na entrevista que Fernando Collor concede à repórter Neusa Sanches da revista eletrônica Istoé Gente, à época do final de seu exílio político, transcrita no ANEXO E, o político anuncia que dará uma festa para comemorar sua volta à vida política e divulga seus planos de candidatar-se novamente a algum cargo, se não a presidente, pelo menos a senador por Alagoas, plano que acabará por se realizar apenas na eleição de 2006. No exemplo 45, ao ser indagado sobre como era estar fora da política, ele se refere metaforicamente a essa situação como inferno. Mais adiante, no exemplo 46, ele abranda a caracterização do exílio conceptualizando-o como interrupção de seu caminho, que agora ele pretende retomar com a candidatura ao Senado.

(45) Os dois anos depois que saí do governo, foram os piores de minha vida. Eu não acredito em inferno, na concepção comum que as pessoas crêem. Acho que o inferno é o que a gente vive aqui mesmo. Mas essa concepção de inferno, eu vivi nesses dois anos. (linhas 69 a 73)

(46) Nas democracias ocidentais o caminho natural de ex-presidentes é o Senado. A única exceção é nos Estados Unidos, onde o ex-presidente é mumificado em vida. Ganha uma biblioteca e cinco seguranças e não pode ser mais nada e vai fazer palestras. Se eu tivesse cumprido o meu mandato, teria tentado o Senado, em 1998. Houve uma interrupção política, que agora estou retomando. (linhas 104 a 108) 
Comparando-se essas verbalizações de Collor às feitas na fase em que estava no poder, anteriormente representada pelas transcrições de uma propaganda de campanha (ANEXO A) e do seu discurso de posse como presidente (ANEXO B), quando foi estabelecida a metáfora conceptual GOVERNAR É CONDUZIR POR UMA ESTRADA e Collor se colocava como condutor do povo brasileiro, pode-se perceber por meio dos termos caminho e interrupção e da ideia de retomada da vida política e do poder que algumas de suas declarações ainda são desdobramentos dessa metáfora.

Em outro segmento da mesma entrevista (exemplo 47), nota-se ainda a referência a FORÇA, quando Collor declara que veio candidatar-se em São Paulo, segundo ele, o estado que detém as forças econômica e política, para pôr à prova sua capacidade de eleger-se a um cargo público. Ele caracteriza metaforicamente seu alívio e sua tranquilidade com a expressão alma lavada, mas não abre mão de também evidenciar que em sua retomada há FORÇA e o faz com a utilização do substantivo ímpeto. A jornalista pergunta se ele não será mais candidato por São Paulo e ele responde:

(47) A minha vinda para São Paulo prova que eu não estava atrás de um mandato. Se assim fosse, eu tentaria ser eleito em Alagoas. São Paulo detém as forças econômica e política. Antigamente, o peso político estava dividido entre Minas Gerais, Rio, Rio Grande do Sul e São Paulo. E hoje os grandes partidos, os maiores políticos e os principais debates estão em São Paulo. Assim, vim para cá para mostrar que estou com a alma lavada, tranqüila (sic) e com o mesmo ímpeto. Embora com muito mais ponderação, experiência e amadurecimento. (linhas 96 a 102)

Entretanto, a realização metafórica que merece uma análise mais profunda, realizada a seguir, por consistir numa metáfora nova, isto é, original ou pouco usual, é a do exemplo 48, também do ANEXO E, e que ocorre quando Collor responde à pergunta sobre qual teria sido o pior momento do seu período de afastamento da política:

(48) Passei dois anos, logo depois da minha saída do governo, em que eu não conseguia dormir antes das sete da manhã. Foi na época em que ainda morava na Casa da Dinda, em Brasília. Assistia a todos os noticiários, lia compulsivamente os jornais. Eu chorava. Tinha abatimento profundo. Um político sem mandato é como uma cobra sem veneno. (linhas 53 a 57)

\subsubsection{A seleção de uma metáfora em particular}

Acredita-se que a análise da metáfora da cobra sem veneno seja bastante significativa, pois ela representa a conceptualização que o locutor faz do político que não tem mandato, condição que ele experimentava à época em que foi entrevistado. Se tomado fora do contexto em que se encontra, o segmento Um político sem mandato é como uma cobra sem veneno faz 
referência a um político indefinido, contudo, tal segmento finaliza uma resposta em que Collor usa a primeira pessoa, nos termos minha e $e u$, para falar da própria rotina depois da saída do governo, portanto, pode-se afirmar que o locutor também fala de si mesmo. O fato de tal expressão ser antecedida de uma narrativa que relata o comportamento abatido do locutor no início do exílio político permite observar uma relação causal que se enuncia na caracterização metafórica e que remete a ele como político sem mandato.

A preocupação em verificar a autenticidade das declarações de Fernando Collor durante a entrevista revista eletrônica Istoé Gente (ANEXO E) incluiu contatos por meio de correio eletrônico com a entrevistadora, repórter Neusa Sanches, confirmando que a reprodução das respostas do ex-presidente Fernando Collor, em especial da metáfora complexa Um político sem mandato é como uma cobra sem veneno corresponde ao que ele efetivamente disse, não tendo sido objeto de edição. A denominação 'metáfora complexa', atribuída ao segmento em análise, segue orientação de Lakoff e Johnson (1999), que dizem haver metáforas complexas 'moleculares' compostas de átomos, as metáforas primárias, que se agrupam para formá-las, a partir de conhecimentos e crenças aceitos em determinada cultura.

No caso de se fazer uma descrição da anatomia da metáfora complexa Um político sem mandato é como uma cobra sem veneno, conforme propõem os autores citados (op. cit.), poderíamos dizer que a crença cultural de nossa sociedade que a originou é a de que 'Políticos que exercem cargos públicos para os quais foram eleitos são pessoas poderosas', e que as metáforas primárias que a compõem seriam PESSOAS SÃO ANIMAIS e PODER É FORÇA. Numa composição desses conceitos metafóricos primários, pode-se encontrar metáforas conceptuais como POLÍTICOS SÃO COBRAS, animais cuja força vem do veneno, TER UM MANDATO É TER FORÇA, PODER POLÍTICO É FORÇA ANIMAL, e até mesmo o seu correspondente negativo PERDA DE PODER POLÍTICO É PERDA DE FORÇA, do qual o segmento metafórico-discursivo em questão é um mapeamento possível, pela situação de perda de poder em que o locutor se encontra. ${ }^{9}$

No segmento Um político sem mandato é como uma cobra sem veneno, a metáfora é expressa discursivamente na estrutura clássica 'A é como B', por meio da qual se permite compreender o aspecto de um conceito A, neste caso o 'político sem mandato', em termos do

\footnotetext{
${ }^{9}$ É necessário acrescentar que a seleção de tal elemento do léxico (cobra) pode remeter a diversos significados, como poderosa, perigosa, traiçoeira, não confiável, e que, no contexto em que se encontra tal realização, a primeira possibilidade (poderosa) parece ser a que se põe em evidência.
} 
conceito B, a 'cobra sem veneno', conforme propõe a teoria cognitivista de Lakoff e Johnson, 2002 [1980], p. 47), em que esses autores afirmam que "A essência da metáfora é compreender e experienciar uma coisa em termos de outra.". Neste caso, o conceito de ‘político sem mandato', aqui constituindo o domínio alvo, ou seja, o conceito mais abstrato a ser definido, é transposto a outro domínio de experiência, mais concreto, a 'cobra sem veneno', o chamado domínio fonte, numa operação que facilitará a conceptualização.

Em suma, Collor, ao explicar o estado emocional que subjetivamente experimentava, em decorrência de seu afastamento compulsório da política, recorre a uma expressão que remete ao comportamento de um animal sem forças, uma cobra que perde seu veneno. Vale também destacar que o segmento em que ele utiliza a metáfora vem em seguida ao termo abatimento, que já contém o significado de diminuição de forças, de esgotamento e prostração em que o locutor se encontra.

Pesquisando-se a vasta simbologia da cobra, ou serpente, em Chevalier e Gheerbrant (2009, p. 814) encontra-se uma contraposição desse animal ao homem, caracterizados como rivais, mas opostos complementares. Esses autores afirmam que "há algo da serpente no homem e, singularmente, na parte de que o seu entendimento tem o menor controle.", o que autoriza dizer que a cobra representa no homem o que ele tem de mais instintivo, incontrolável.

Por outro lado, embora para uma parcela significativa da cultura ocidental dos dias de hoje a serpente seja considerada uma força hostil e desencadeie aversão e temor, nas culturas ditas primitivas, incluindo-se aí a tupi-guarani, ela se mantém como arquétipo completo e fundamental ligado às fontes da vida, da fecundidade, do rejuvenescimento - por causa da troca de pele - e da imaginação. Tais valências simbólicas, aparentemente contraditórias, são, porém, complementares e indispensáveis à realização da harmonia. A poesia, as artes, as ciências médicas, principalmente estas últimas, por incluírem a serpente em seus símbolos profissionais, encarregam-se de reabilitar sua simbologia mais positiva. (op. cit.)

Chama a atenção para a análise o fato de que, entre tantas formas de definir sua experiência como político sem mandato, Fernando Collor teria escolhido a imagem da cobra sem veneno para fazê-lo, numa associação que pode ser considerada pouco usual. A esse respeito, Kövecses (2010, p. 289) afirma que, em discursos reais, frequentemente nos deparamos com metáforas novas ou não convencionais, o que ele chama de 'criatividade metafórica'. Essa criatividade, segundo o autor, pode ocorrer devido à influência de aspectos 
contextuais do discurso, como o contexto linguístico imediato, o que se sabe sobre as entidades participantes do discurso, os cenários físico e social, além do contexto cultural.

Neste caso em particular, parece adequado dizer que a conceptualização metafórica do político sem mandato por meio da imagem da cobra sem veneno pode ter sido influenciada culturalmente, dada a criação e a educação de Fernando Collor, nascido no Rio de Janeiro, mas descendente de tradicional família de Alagoas, região nordeste do país. $\mathrm{Na}$ cultura nordestina, o hábito de conceptualizar o SER HUMANO por meio do domínio fonte dos ANIMAIS é bastante comum, haja vista as denominações "cabra" e "cabra macho", utilizadas com frequência para identificar a força e a resistência do homem do povo no nordeste brasileiro.

Ao estudar a influência cultural na variação metafórica, Kovecses (2005) sugere que as metáforas baseadas em experiências cognitivas universais, em geral as denominadas 'primárias', como CAUSAS SÃO FORÇAS, pouco variam e podem, portanto, ser consideradas universais. Entretanto, a variação metafórica também é importante, e a tendência é que as metáforas complexas - como o exemplo aqui estudado Um político sem mandato é como uma cobra sem veneno - sejam manifestações de como um conceito abstrato primário nesse caso PODER É FORÇA - pode ser entendido em uma variedade de diferentes formas interculturais Este pesquisador acredita que as culturas influenciam enormemente quais metáforas conceptuais complexas emergem das metáforas primárias, portanto as considerações culturais são mais importantes na análise das metáforas complexas.

Num posterior estudo sobre metáforas que contempla os domínios fonte mais comuns, Kövecses (2010) afirma que o domínio fonte dos ANIMAIS é extremamente produtivo, principalmente como forma de conceptualizar seres humanos, isto é, frequentemente pessoas são caracterizadas em termos de propriedades de animais. Este estudioso também afirma que, aparentemente, a grande maioria das metáforas relacionadas a animais referem-se a características negativas dos seres humanos, apresentando o foco significativo das metáforas conceptuais COMPORTAMENTO HUMANO É COMPORTAMENTO ANIMAL e PESSOAS SÃO ANIMAIS como de objeção ou de ‘indesejabilidade’. (op. cit., p. 153)

Sobre essa colocação, parece que a escolha do termo cobra, principalmente ao ser empregado por um político que procura construir uma imagem positiva de si mesmo como é Fernando Collor, não contemple os aspectos negativos de sua personalidade, como uma primeira interpretação pode fazer supor, mas refira-se à inutilidade de ser um político sem 
mandato, comparativamente à inutilidade de ser uma cobra sem veneno. Vale lembrar também que as cobras só atacam, inoculando seu veneno no suposto inimigo, quando se sentem ameaçadas, numa espécie de legítima defesa, uma característica desse animal que, transposta para conceptualizar o político, pode desculpá-lo de qualquer atitude mais agressiva, já que ele só 'atacaria' ao se sentir ameaçado.

Certamente as considerações anteriores referem-se preferencialmente ao processo discursivo produtivo, pois não foi possível verificar com profundidade o processo interpretativo de tais manifestações. Porém, expressões metafóricas como 'cobra sem veneno', usadas com o propósito retórico de “defender uma ideia enfaticamente”, podem ser objeto de potenciais 'usurpações' contra as intenções do locutor e ser usadas contra ele. (KÖVECSES, 2010, p. 287)

A metáfora, já referida na presente pesquisa como figura de identidade frágil (MEYER, 2007), carrega em si muitos significados possíveis, característica que pode se mostrar de grande utilidade na produção do discurso político, mas que também pode provocar uma interpretação indesejada por parte do locutor. Talvez Fernando Collor não tenha avaliado a probabilidade da sua opção em comparar-se metaforicamente a uma cobra ser mal interpretada por seus interlocutores, mas esse detalhe não pode passar despercebido ao analista do discurso. O termo cobra pode sim emprestar um significado negativo à caracterização da identidade de Collor, como a maioria das caracterizações metafóricas com domínio fonte em cobra - como animal venenoso, traiçoeiro - o fazem.

A metáfora discursiva constituiu um importante instrumento utilizado por Fernando Collor na construção de uma identidade em que o conceito de FORÇA é a base, afirmação observável por meio das metáforas conceptuais estabelecidas para as amostras pesquisadas. Na propaganda de 1989 (ANEXO A) e no discurso de posse em 1990 (ANEXO B), ao pleitear ou exercer cargos públicos, estabeleceram-se as metáforas conceptuais: POLÍTICA É UM COMBATE SAGRADO e GOVERNAR É CONDUZIR POR UMA ESTRADA, em que é possível identificar o Collor lutador e condutor, exercendo a FORÇA.

Quando Collor é afastado do poder, período representado nas amostras: "Crônica de um Golpe" (ANEXO C) e a entrevista ao Programa Livre (ANEXO D), o político caracterizase metaforicamente enfraquecido como vítima de algozes violentos, seus adversários. Ao final desse período de exílio político, na entrevista à Istoé Gente (ANEXO E), pode-se ainda 
estabelecer a metáfora conceptual PERDA DE PODER POLÍTICO É PERDA DE FORÇA, um indício de que o poder é a FORÇA perdida.

Do discurso de posse como Senador (ANEXO F), em 2007, em que Collor relembra detalhadamente episódios do exílio, foram retirados os exemplos seguintes, cuja análise permite apontar as metáforas conceptuais POLÍTICA É GUERRA, sobre o exercício da ação política, e SOFRIMENTO É FERIMENTO FÍSICO, sobre a FORÇA que seus adversários exercem sobre ele, como estruturas subjacentes que remetem ao esquema da FORÇA.

Observa-se que os termos combate e trégua, do exemplo 49, perseguição e cavalo de batalha, do exemplo 50, e ataques, do exemplo 51, são expressões metafóricas que conceptualizam o exercício da AÇÃO POLÍTICA por meio do domínio da GUERRA. Já os termos marcas e martírio, do exemplo 49, mossas e cicatrizes, do exemplo 52, violência, do exemplo 53, e imputações, mutilação e imposto, do exemplo 54, são seleções metafóricas que definem SOFRIMENTO como FERIMENTO FÍSICO.

(49) Durante a semana destinada à votação e apuração das eleições de 3 de outubro, cessou temporariamente o combate encetado pelas marcas deixadas pelos pleitos de 15 de novembro e 17 de dezembro de 1989. Foi a única trégua em todo aquele martírio. (linhas 1337 a 1340)

(50) Isso aqui é uma perseguição, é uma ação deletéria, o Governo não vai fornecer qualquer tipo de informação para que essa CPI se transforme em um cavalo-de-batalha contra o Governo. (linhas 858 a 860)

(51) Mais uma vez convocou-se o Congresso Nacional para reunir-se em caráter extraordinário, no período de 25 a 31 do mesmo mês. $O$ ato legítimo custou-me novos e virulentos ataques, incompatíveis com a dignidade e a seriedade do ambiente em que foram proferidos,... (ANEXO F, linhas 1461 a 1464)

(52) (...) os episódios que aqui vou rememorar obrigaram-me a padecer calado e causaram mossas na minha alma e cicatrizes no meu coração. (linhas 3-4)

(53) A violência cometida com a suspensão de meus direitos políticos... (linha 1756)

(54) ... de todas as imputações que suportei, restaram a mutilação de meu mandato e o ostracismo político que me foi imposto. (linhas 1746 a 1748)

Nesse discurso, reproduzido no (ANEXO F), o locutor propõe passar a limpo toda a sua trajetória até aquele momento para assumir seu mandato e recompor-se 'fisicamente', retomando sua carreira política. Os segmentos metafóricos 'uma pessoa inteira' (exemplo 55) e 'virar definitivamente aquelas páginas doídas da minha vida pública' (exemplo 56) dos exemplos que seguem, anunciam a condição de mudança na construção da identidade, num início de retomada de poder. 
(55) Obrigado, enfim, a todos aqueles que se pronunciaram dando-me as boas-vindas e fazendo-me sentir, finalmente, uma pessoa inteira,...(linhas 1805-6)

(56) Hoje, dia 15 de março de 2007, conforme V. Exas. Afirmaram, posso virar definitivamente aquelas páginas doídas da minha vida pública... (linhas 2064-2065)

Todavia, construir identidades não é a única função metafórica a ser examinada neste estudo. Considerou-se necessário conhecer ainda outras razões de se utilizarem metáforas em nossa comunicação, principalmente no discurso político, em que, como afirmam Chilton e Ilyin (1993) a metáfora desempenha um papel heurístico, ou cognitivo, de instrumento conceitual que auxilia as pessoas a pensarem sobre situações novas, utilizando conceitos já conhecidos e/ou mais concretos. Outra questão de interesse é relacionar a escolha metafórica do locutor, carregada da ideologia que ele valoriza, a seu propósito argumentativo, ou seja, compreender como acontece sua opção por determinada metáfora como objeto persuasivo, o que demanda um estudo mais apurado a respeito da metáfora inserido na Teoria da Argumentação. 


\section{CAPÍTULO III}

ARGUMENTAÇÃO

E

METÁFORA:

A TRÍPLICE PERSPECTIVA 


\subsection{Por que as pessoas falam metaforicamente?}

Gibbs (1994, p.124) indica três hipóteses para explicar por que as pessoas falam metaforicamente: as hipóteses de expressabilidade, compactividade e vivacidade. A hipótese da expressabilidade propõe que a metáfora permite veicular ideias que não poderiam ser facilmente expressas por meio da linguagem literal. A hipótese da compactividade sugere que as metáforas possibilitam a comunicação de complexas configurações de informação de maneira econômica. E, por fim, a hipótese da vivacidade veicula a ideia de que, utilizando linguagem metafórica, os falantes podem expressar imagens mais ricas, detalhadas e vívidas de sua experiência fenomenológica e subjetiva, do que se usassem linguagem literal.

Retome-se do exemplo 25, (página 56), a metáfora da "Caça aos marajás" (ANEXO A), muito significativa na campanha de Collor, visto que foi até empregada como slogan de campanha e, na variação "caçador de marajás", identificava o perfil do candidato: ... foi para acabar com esta pouca vergonha... minha gente... que lutei TANto em Alagoas... e iniciei
uma cruzada que chegou ao Brasil inTEIro... a CAça aos maraJÁS...(linhas 10 a 13)

Com base na hipótese de expressabilidade de Gibbs, é possível dizer que a referida metáfora consegue exprimir a variedade de pensamentos e características contidas no termo 'caça', que engloba perseguição e submissão, numa clara alusão à posição de superioridade em que se coloca o locutor, já que ele será o 'caçador' a dar cabo dos 'marajás'. Este último termo, 'marajás', é tomado mais pelo sentido negativo que acrescenta aos funcionários públicos e, depois, durante a campanha, a todos os 'corruptos' a serem combatidos, pois pretende realçar o fato de que eles trabalham pouco, principalmente em comparação ao modelo de trabalhador empenhado que Collor constrói em sua fala, representado pelo auditório a quem se dirige.

Pode-se ainda dizer que tamanha quantidade de informação foi transmitida de maneira bastante compacta (hipótese da compactividade) e de forma muito mais rica (hipótese da vivacidade), pois as imagens da figura do 'caçador' que persegue e subjuga o 'marajá', além de remeterem a movimento e atitude, de certa forma embelezam o que é comunicado ao auditório. O uso desta e de outras metáforas na prática discursiva de Fernando Collor configura uma clara preferência do locutor, principalmente quando o objetivo é persuadir, por usos de linguagem que privilegiam aspectos subjetivos e emocionais, em detrimento de outros com apelo mais racional. 
Num desdobramento da definição aristotélica de que a metáfora é uma forma de dar a uma coisa um nome que pertence a outra, Chilton e Ilyin (1993, p.9) afirmam que as metáforas são usadas para comunicar e fazer compreender situações problemáticas em termos de situações mais familiares, 'lubrificando' um possível atrito nas interações entre os indivíduos. O emprego da metáfora ajudaria a evitar referências diretas a assuntos mais delicados, minimizando a responsabilidade do orador em relação a atos de fala mais ameaçadores, uma característica de grande utilidade no discurso político, cujos temas são frequentemente polêmicos.

Remetendo ainda ao uso da metáfora no discurso político, Chilton e Ilyin (op. cit.) acrescentam que, do ponto de vista cognitivo, a metáfora pode ser um instrumento heurístico para a exploração de novos conceitos políticos. Uma nova metáfora, como no caso da denominação “caçador de marajás”, assumida por Fernando Collor durante sua campanha para presidente, pode introduzir novas opções à imaginação e ao pensamento político, sobrepondo-se a conceitos já existentes.

Esses autores estudaram expressões metafóricas extraídas do discurso político europeu, tais como 'cortina de ferro', e explicam que, quando uma nova metáfora veiculada pela mídia é tão significativa a ponto de atrair a atenção pública, os políticos tentam controlála e interpretá-la, pois uma hábil manipulação desta metáfora pode levar à implantação da nova ideia política que ela representa. Além disso, uma nova proposta política é expressa por meios verbais e resulta em ações correspondentes a essas formulações e declarações, e é provável que a metáfora presente nessas manifestações discursivas, além do heurístico, também desempenhe um papel interacional. Segundo Chilton e Ilyin:

The first point is that at the stage at which a coherent policy discourse is developed, it is likely that metaphor plays both a heuristic and an interactional role. By 'heuristic' here is meant the cognitive function of metaphor: metaphor as a conceptual instrument that enables people to think about situations that are new, complex or remote. By 'interactional' here is meant the function metaphor has as a means of, for instance, avoiding direct reference, of creating common ground, or of maintaining contextual continuity and cohesion. $(1993, \text { p. } 10)^{10}$

\footnotetext{
${ }^{10}$ Tradução livre: O primeiro ponto é que, na fase em que é desenvolvido um discurso coerente sobre uma política, é provável que a metáfora desempenhe um papel heurístico e interacional. Por 'heurística' aqui se entende a função cognitiva da metáfora: metáfora como um instrumento conceitual que permite que as pessoas pensem sobre situações que são novas, complexas ou remotas. 'Interacional' aqui significa a função que a metáfora tem como meio de, por exemplo, evitar referência direta, criar terreno comum, ou manter a continuidade e a coesão contextuais.
} 
O fato de Fernando Collor ter se apropriado da metáfora "caçador de marajás", denominação que surgiu na mídia no início de seu mandato como governador em Alagoas, em 1987, por motivo de se recusar a pagar salários que considerava exagerados a funcionários públicos de Maceió, pode ser um bom exemplo das funções heurística e interacional que uma metáfora desempenha na promoção de um novo conceito político. Como ela atraiu a atenção pública, durante a campanha à presidência em 1989, Fernando Collor tratou de reforçar a ideia de combate à corrupção que a denominação metafórica continha, combinando-a com a imagem de um candidato jovem e ousado. Além disso, por meio da manipulação dessa metáfora, implantou a ideia que ela representava, certamente com o objetivo retórico de persuadir seus interlocutores.

Completando a metodologia sugerida por Fairclough (1997, p. 83) de descrição linguística, que apontou utilizações metafóricas relevantes no corpus selecionado, de interpretação da função cognitiva da metáfora e das relações ideológico-culturais dos processos produtivos do discurso de Fernando Collor, para sugerir uma explicação de como esse discurso afetou práticas sociais, o presente capítulo acresce às duas perspectivas abordadas nos capítulos anteriores, a saber: a cognitiva e a ideológico-cultural, a observação da argumentatividade contida na metáfora, ou seja, da ocorrência da metáfora discursiva com o propósito retórico da persuasão. Compor essa tríplice perspectiva de observação, acreditase, ajudará a conhecer melhor as razões das escolhas metafóricas desse interlocutor, contribuindo para uma melhor compreensão de seu discurso.

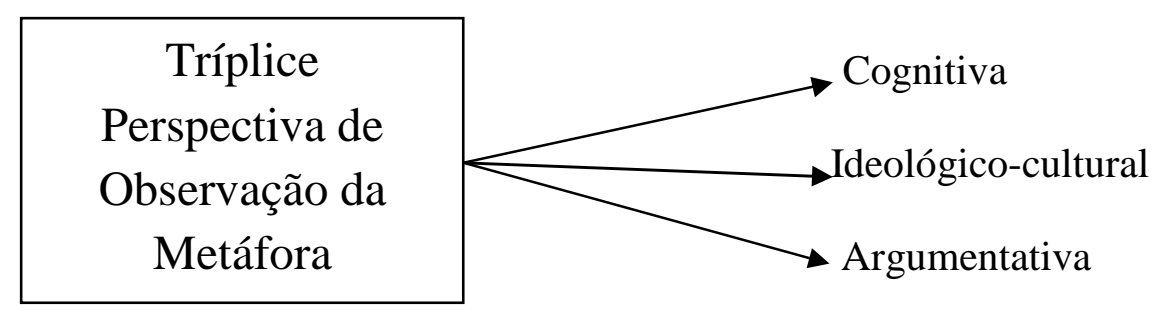

Quadro 3. Esquema da Tríplice perspectiva de observação da metáfora ${ }^{11}$

Como sugere Guimarães (1997, p. 151), a linguagem figurada, e por consequência a linguagem metafórica, pode também ser observada em estudos sobre argumentação, pois constitui forma de expressão que atrai a atenção do leitor ou ouvinte, devido ao efeito de concretude que provoca neles, concorrendo para conquistar sua adesão. Esta estudiosa, ao

\footnotetext{
${ }^{11}$ Sugestão de Palma, a partir da proposta deste trabalho.
} 
considerar a ocorrência de figuras de retórica e argumentação, afirma que é possível relacionar os efeitos delas a fatores gerais de persuasão, e que sua análise está, por isso mesmo, subordinada a uma análise prévia da argumentação, o que será feito a seguir.

\subsection{A Teoria da Argumentação: Metáfora como estratégia argumentativa}

Guimarães (1997) afirma que, atualmente, consideram-se os termos argumentação e retórica como quase sinônimos, concepção também adotada para o presente estudo. No passado, a retórica aristotélica consistia na arte de falar em público de forma persuasiva para conquistar a adesão dos ouvintes, um objetivo que é o mesmo de qualquer processo argumentativo, seja ele oral ou escrito. Houve, porém, um período em que a retórica foi desacreditada, por se limitar ao estudo das figuras de estilo, processo que foi revertido com o surgimento da pragmática, quando o discurso e a argumentação tornaram-se objetos de destaque nos estudos linguísticos.

São os estudos precursores de Perelman e Olbrechts-Tyteca (2005 [1958]), entre outros mais recentes como os de Plantin (2008 [2005]) e Reboul (1998 [1991]), referidos a seguir, que promovem a aproximação entre a retórica aristotélica e a teoria da argumentação, considerando-a ato linguístico de persuasão e buscando caracterizar as diversas estruturas argumentativas.

A respeito desse renascimento, dessa refundação dos estudos sobre a argumentação como uma "Nova Retórica", o subtítulo da obra de Perelman e Olbrechts-Tyteca (2005 [1958]), e tema também de uma publicação contemporânea a essa - de Toulmin (1958) sobre a utilização dos argumentos - Plantin (2008 [2005], p. 8) afirma que a construção de um pensamento autônomo da argumentação dessa época foi, sem dúvida, estimulada pela vontade de encontrar uma noção de "discurso sensato", no sentido de democrático, racional, em oposição aos discursos fanáticos dos totalitarismos. Esse autor também diz que toda utilização estratégica de um sistema significante pode ser legitimamente considerada uma retórica, portanto, existem uma retórica do verbal, do não-verbal, do consciente e do inconsciente. Porém, a argumentação retórica é especificamente definida por ser referencial, isto é, formular o problema dos objetos, dos fatos; probatória, isto é, oferecer, ao menos, a melhor prova; polifônica e ter como objeto a intervenção institucional planejada. 
Quanto às questões da argumentação por meio de estratégias que privilegiam as emoções e a afetividade, o autor reconhece que, em oposição ao campo da argumentação pura, segundo a qual o discurso argumentativo deveria ser impassível e impessoal, rejeitando os afetos e o comprometimento da pessoa com o próprio discurso, estudos contemporâneos sobre emoções tendem a mostrar que há uma relação complexa e não tão facilmente dissociável entre razão e emoção. Para esse estudioso, a análise argumentativa ainda tem que encontrar meios de abordar de modo integral a questão da afetividade, num modelo de construção discursiva de conteúdo tanto lógico quanto patêmico.

Um outro autor que estuda o discurso persuasivo, Reboul (1998 [1991], p. 227), afirma que "retórica é a união íntima entre estilo e argumentação", combinando as definições de Perelman e Tyteca (2005 [1958]), que veem a retórica como arte de argumentar, convencer; e a de Morier (1981), Genette (1969) e Cohen (1966), que consideram a retórica um estudo do estilo, das figuras, daquilo que torna literário um texto. Reboul ressalta a importância desse elemento comum a estas duas posições, a articulação dos argumentos e do estilo numa mesma função, definindo retórica como "arte de persuadir pelo discurso".

Quando Reboul investiga de que maneira um discurso se torna persuasivo, distingue meios de ordem mais racional e outros de ordem mais afetiva, alegando que, em retórica, razão e sentimentos são inseparáveis. Ele cita os argumentos que se integram no raciocínio silogístico e os que se fundamentam em exemplos como meios de competência da razão, além de relacionar à afetividade o ethos, caráter que o orador deve assumir para chamar a atenção e conquistar a confiança do auditório, e o pathos, os desejos e as emoções do auditório, de que o orador poderá tirar partido para impressionar seus interlocutores. (1998 [1991], p. XVII)

Reboul (op. cit.) afirma que a função persuasiva do discurso comporta dois aspectos, o argumentativo e o oratório, neste último, incluindo os gestos, o tom e as inflexões de voz do orador. Indica que figuras de estilo como a metáfora e a hipérbole podem ser tanto consideradas oratórias, por agradarem ou comoverem, como argumentativas, por expressarem com mais contundência um argumento ao condensá-lo. (p.XVIII) Para este autor, a figura seria uma licença estilística que o orador usa para facilitar a aceitação do argumento, para falar distintamente e com vivacidade.

Esse mesmo autor ainda relaciona as funções hermenêutica, heurística e pedagógica da retórica, enfatizando sua importância na arte de compreender o sentido das palavras, de descobrir o verossímil e de aprender a bem dizer. Reboul (op. cit.) admite ser a arte necessária 
à expressão, pois, sem ela, seria difícil inspirar confiança ou ser compreendido; entretanto, aconselha a não confundir arte com artifício, pois um discurso que parece artificial é ineficaz, não consegue persuadir. Talvez resida aqui a ineficiência do discurso de Fernando Collor nos períodos em que se afastou do poder, pois a criação de uma identidade de injustiçado e vítima da violência de seus adversários soou artificial a seus interlocutores, não propiciando que atingisse seu propósito argumentativo.

A inserção dos estudos sobre a metáfora na construção do discurso persuasivo também pode ocorrer quando se observa a definição, já tão conhecida, proposta por Perelman e Olbrechts-Tyteca sobre a Teoria da Argumentação, que "estuda as técnicas discursivas que permitem provocar ou aumentar a adesão das mentes às teses que se apresentam ao seu assentimento" (2005 [1958], p.4). Tais autores consideram central, na arte de persuadir, o papel do gênero epidítico, denominação proposta por Aristóteles aos discursos de louvor ou censura, persuasivo por criar consenso e comunhão em torno de alguns valores e desencadear emoções que levem à adesão a esses valores e, consequentemente, à ação, num claro processo de interação social. Para Perelman e Olbrechts-Tyteca, a razão nem sempre é suficiente para persuadir. Eles afirmam que:

(...) quem visa a uma ação precisa, que se desencadeará no momento oportuno, deverá, ao contrário, excitar as paixões, emocionar seus ouvintes, de modo que se determine uma adesão suficientemente intensa, capaz de vencer ao mesmo tempo a inevitável inércia e as forças que atuam num sentido diferente do desejado pelo orador. (op. cit. p.52)

Ao analisarem-se as amostras do corpus, pode-se observar que Fernando Collor utiliza-se tanto de estratégias argumentativas que apelam à razão, como daquelas que pretendem convencer pela emoção. Entretanto, a esta pesquisa interessa estudar a utilização que Collor faz de linguagem metafórica enquanto estratégia argumentativa que pretende persuadir mais por emocionar do que por raciocinar junto a seu auditório.

Ao caracterizar, como nos exemplos retomados das páginas 56 e 33 que seguem, sua ação política como luta, cruzada e caça aos marajás (exemplo 25), e colocar-se como parceiro/condutor do povo brasileiro no caminho do desenvolvimento com os termos metafóricos transição, rumos e trilha (exemplos 3, 4 e 5), o político envolve seu auditório num clima emocional pela utilização imagens ricas e detalhadas de experiências concretas.

(25) ... foi para acabar com esta pouca vergonha... minha gente... que lutei TANto em Alagoas... e iniciei uma cruzada que chegou ao Brasil inTEIro... a CAça aos maraJÁS...(linhas 10 a 13) 
(4) Temos compromissos com a justiça social, temos compromissos com o desenvolvimento, com a liberdade e com o progresso que haverá de nortear os rumos deste País, a partir deste 15 de março. (linhas 4 a 6)

... para que nós encontremos, definitivamente, a trilha do crescimento econômico e da justiça social! (linhas 32 e 33)

Perelman e Olbrechts-Tyteca (op. cit.) apontam para a importância argumentativa da metáfora pelo fato de a considerarem uma analogia condensada, sendo que esta desempenha o papel de estruturar e situar um tema num âmbito conceitual. Estes estudiosos salientam que o valor argumentativo da metáfora vem-lhe da analogia que lhe subjaz e ela esconde. O poder persuasivo da metáfora estaria no envolvimento que ela suscita entre locutor e auditório por acionar, em sua produção e recepção, modelos mentais aparentemente comuns entre ambos, o que os aproxima por meio da emoção. O segmento seguinte ilustra bem estas afirmações:

...com o dinheiro que se desperdiça HOje com os marajás nós vamos ISSO SIM... pagar melhores salários ao funcionário público que REalmente trabalha...(linhas 21 a 23)

O fato de caracterizar metaforicamente seus oponentes como marajás, ou seja, príncipes que não trabalham, justifica o fato de combatê-los, pois seu salário é um desperdício que poderia servir para pagar melhor quem realmente trabalha. Neste caso, a escolha metafórica constitui uma estratégia sutil de argumentação, que envolve o interlocutor mais pelo que oculta do que pelo que revela. Em períodos mais recentes, entretanto, depois da retomada do poder ao assumir o cargo de senador, Fernando Collor prioriza uma seleção linguística menos sutil, como acontece com o exemplo abaixo, segmento extraído do ANEXO G:

...(e) a minha mão peSAda vai cair em cima deles:... ((aplausos)) e eles vão deixar:.... e eles vão deixar::... vão deixar:: a sociedade alagoana em paz...

O segmento faz parte do discurso de lançamento da candidatura de Fernando Collor ao governo de Alagoas, ocorrido em 30 de junho de 2010, em Maceió. Sentindo-se fortalecido por quase quatro anos como senador, Fernando Collor pronuncia, nesta ocasião, um discurso em que recupera elementos metafóricos relativos ao exercício da FORÇA. Versões dessa manifestação foram divulgadas nos mais variados meios de comunicação, entre eles a revista Veja, edição 2172 - ano 43 - nº 27 de 7 de julho de 2010, que a publicou, na seção Panorama - Veja Essa, p. 60. Embora a análise efetuada a seguir refira-se à transcrição do audiovisual, conforme o exemplo 58, a reprodução da imagem publicada em Veja vem a seguir, a título de ilustração: 
650u um recado aos bandidecos de $m$...: que saiam de Alagoas, ou vão sentir a minha mão mais pesada, que vai cair sobre eles.

FERNANDO COLLOR DE MELLO, candidato ao governo de Alagoas, no seu velho estilo bandidão

(ANEXO G)

Como é costume nos discursos de campanha, como esse, há no segmento uma promessa vinculada à recuperação de poder que remete à metáfora conceptual CONTROLAR É SEGURAR (ALGO NAS MÃOS), que também já foi determinada como subjacente ao relato "Crônica de um golpe", ANEXO C. Naquela ocasião, o poder estava 'escapando das mãos' do locutor, enquanto, no exemplo 58, a situação se inverte, pois há a afirmação de que a 'mão de Collor', expressão metafórica com base metonímica que toma parte do corpo de Collor, a mão, para significar a totalidade de sua pessoa, vai cair sobre seus adversários, caso ele se eleja governador.

A expressão a minha mão pesada, em que um 'peso' é atribuído à mão, antecipa ainda que essa mão controladora, ao recuperar o poder, imprimirá FORÇA ao atingir os perseguidos, o que parece ser, como também anuncia a revista Veja, uma retomada do estilo que valoriza o exercício da FORÇA nas manifestações discursivas de Fernando Collor. Na verdade, a considerar os estudos efetuados nesta pesquisa, é possível constatar que Fernando Collor nunca abandona o esquema da FORÇA em seu discurso, ele apenas muda a direção dessa força, que ele aplica ao exercer o poder, e com a qual é atingido, quando o poder lhe escapa das mãos. Para ele, PODER É FORÇA.

A metáfora PODER É FORÇA pode ser considerada uma chave conceptual, conforme nomenclatura proposta por Charteris-Black (2004, p.244) e já descrita anteriormente na página 38 desta pesquisa, por seu grau maior de abstração, que estaria subjacente a metáforas conceptuais como POLÍTICA É UM COMBATE SAGRADO, GOVERNAR É CONDUZIR POR UMA ESTRADA, CONTROLAR É SEGURAR (ALGO NAS MÃOS), PERDA DE PODER POLÍTICO É PERDA DE FORÇA, POLÍTICA É GUERRA, já estabelecidas para as diversas amostras do corpus estudadas. Segue uma possível representação esquemática dessa afirmação: 
CHAVE CONCEPTUAL

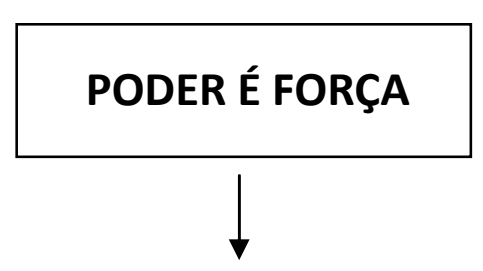

METÁFORAS CONCEPTUAIS

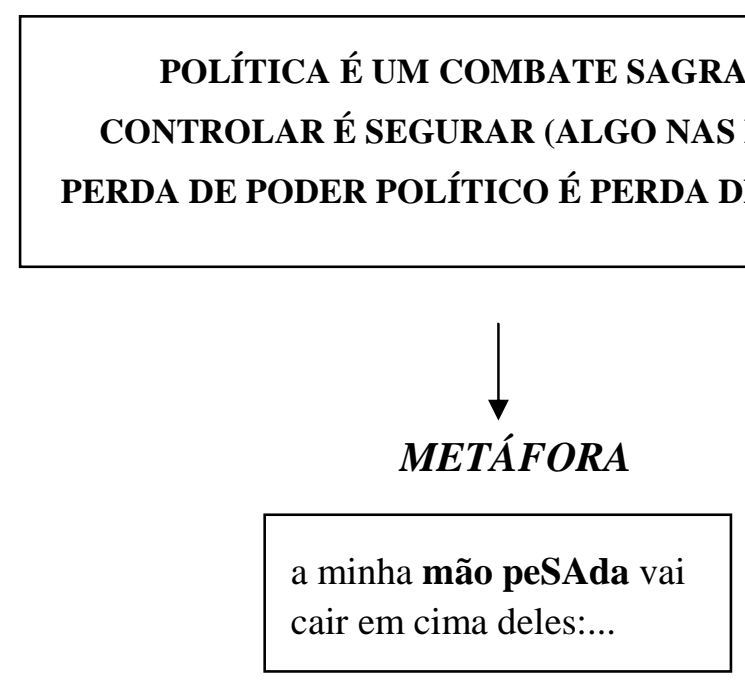

Quadro 4 . Modelo hierárquico-cognitivo de metáforas presentes no discurso de Fernando Collor

As escolhas metafóricas de Fernando Collor permitiram chegar à chave conceptual PODER É FORÇA porque foram observadas em relação a seus aspectos cognitivos, culturais e argumentativos. Considera-se que tais escolhas revelam seu processo cognitivo, suas influências culturais e ideológicas, e indicam que, para Collor, o exercício da ação política envolve FORÇA, seja ela favorável ou contrária a ele. Além disso, porque ele crê que essa escolha seja também valorizada por seus interlocutores, utiliza-a como elemento persuasivo.

Autores como Lakoff e Johnson (2002[1980], p. 238-239) também confirmam o poder argumentativo da metáfora ao dizer que ela é capaz de provocar uma resposta imediata, "guiando nossas futuras ações, de acordo com ela." Ainda para estes autores, as metáforas podem funcionar como eficientes estratégias argumentativas, porque elas "sancionam ações, justificam inferências e ajudam a estabelecer metas."

Charteris-Black (2004) diz que a metáfora, como transmissora de significados expressivos, não pode ser ignorada em seu papel de formadora de opiniões, constituindo, fundamentalmente, um ato discursivo de persuasão, porque convida a uma percepção partilhada que transcende o sistema semântico. Este autor comenta que, com o surgimento das 
abordagens semântico-cognitivas da metáfora e o crescimento da Análise Crítica do Discurso, estudiosos como Chew (2000), Musolf (1998) e Chilton e Ilyin (1993), entre outros, realizaram inúmeros estudos sobre o uso de metáforas em diferentes tipos de discurso político, relacionando, cada um na medida de seus interesses, as características linguísticas da metáfora com temas como racismo, nacionalismo ou ética. O que essas pesquisas têm em comum é que as metáforas são vistas como importantes meios de conceptualizar temas políticos e construir visões de mundo.

Preocupado também com a questão da escolha metafórica, Charteris-Black (2004) afirma que o objetivo retórico da persuasão é fator importante para que o locutor opte por esta ou aquela realização discursiva e que, portanto, em muitos casos, a escolha metafórica é motivada pela ideologia, uma dimensão da metáfora revelada pela Análise Crítica do Discurso.

Esse autor diz que um mesmo tema poderia ser comunicado por meio de diferentes metáforas, conforme a ideologia subjacente a ele, além do que, de acordo com a perspectiva ideológica, também é possível empregar as mesmas metáforas de modo diferente. CharterisBlack (op. cit.) cita o exemplo do discurso político, em que não é obrigatório usar metáforas de conflito e, se isso ocorre, tais metáforas tanto podem ser usadas para atacar o ponto de vista do oponente, como para representá-lo como agressor. Por essas razões, o autor afirma que o emprego de diferentes aspectos do domínio fonte corresponde a diferentes perspectivas ideológicas.

Este estudioso reivindica que uma teoria completa da metáfora deve incorporar às abordagens linguísticas e semânticas já tradicionais, uma perspectiva pragmática, que interprete a escolha metafórica com referência aos propósitos de uso dentro de contextos discursivos específicos, apontando que escolhas metafóricas podem ser orientadas por considerações cognitivas, semânticas e pragmáticas, além de ideológicas, culturais e históricas. Ele acrescenta que:

There is nothing, then, deterministic about metaphor use - as cognitive linguistics implies. The communicative purpose (or speaker intention) within a particular context of use will activate the affective potential of metaphor by exploiting different aspects of its individual and/or social motivation. (...) Once metaphor choice is seen as a conscious selection of one linguistic form to make a discourse persuasive, we can explain this choice with reference to both social and individual considerations. A certain combination of these is 
likely to be effective in persuading by arousing particular emotions. (p. $249)^{12}$

Pode-se dizer, então, que, ao se considerar este aspecto da produção do discurso metafórico orientada por considerações individuais e sociais, existe a possibilidade de estabelecer uma relação particular entre discurso e ideologia ao analisar as manifestações discursivas de Fernando Collor. Neste sentido, reconhece-se que suas escolhas metafóricas discursivas não são aleatórias, têm objetivo argumentativo, e as metáforas conceptuais subjacentes a elas refletem seu sistema cognitivo e suas raízes culturais, possibilitanto que, num nível maior de abstração, a 'chave conceptual' PODER É FORÇA, resuma a ideologia que as governa.

\footnotetext{
${ }^{12}$ Tradução livre: Não há nada, então, determinista sobre o uso da metáfora - como dá a entender a linguística cognitiva. O propósito comunicativo (ou intenção do locutor) dentro de um contexto particular de uso ativará o potencial afetivo da metáfora explorando diferentes aspectos de sua motivação individual e/ou social. (...) Uma vez que a escolha metafórica é vista como uma escolha consciente de uma forma linguística para tornar um discurso persuasivo, podemos explicar esta escolha com referência tanto a considerações sociais como individuais. Uma combinação destas duas é provavelmente efetiva ao persuadir por despertar emoções particulares.
} 
CONCLUSÃO 
Este trabalho teve por proposta estudar as metáforas presentes no discurso de Fernando Collor de Mello com o intuito de compreender a organização de seu processo cognitivo, conhecer suas motivações culturais e ideológicas e detectar a natureza da relação de poder estabelecida entre esse locutor e seu auditório, tendo em vista o caráter persuasivo das manifestações tomadas do discurso político. Para atingir tais objetivos, efetuou-se uma análise que se nomeia crítica, por descrever as metáforas discursivas utilizadas por tal locutor, interpretá-las ao encontrar as metáforas conceptuais subjacentes a elas e explicar de que maneira esse processo discursivo refletiu e produziu uma realidade.

Para contemplar de forma integrada essa multiplicidade de aspectos da linguagem metafórica empregada por Collor, foi proposta uma Tríplice Perspectiva de Observação da Metáfora (cognitiva, ideológico-cultural e argumentativa), a partir da qual pôde-se constatar que, de maneira simbólica e apaixonada, esse locutor tem apelado ao imaginário e à emoção de seus interlocutores, por meio de seu discurso permeado de linguagem metafórica.

As escolhas linguístico-metafóricas que Fernando Collor faz para representar conceptualmente sua realidade, construindo sua identidade e expressando suas ideias em relação à política, refletem suas experiências cognitivas, culturais e sociais e representam conceitos que ele valoriza e que acredita serem valorizados por seus interlocutores. No conjunto das manifestações discursivas que compõem o corpus, amostras que representam a alternância de sua posição em relação ao poder, ora exercendo-o, ora tentando recuperá-lo, as metáforas discursivas analisadas foram tomadas como desdobramentos de conceitos estruturadores - as metáforas conceptuais - indicadores de como funciona o processo cognitivo de Fernando Collor e de quais são suas influências culturais e ideológicas.

Assim, os conceitos estruturadores a que se chegou pela análise da metáfora discursiva no discurso desse político e que estão representados pelas metáforas conceptuais POLÍTICA É UM COMBATE SAGRADO, GOVERNAR É CONDUZIR POR UMA ESTRADA, CONTROLAR É SEGURAR (ALGO NAS MÃOS), PERDA DE PODER POLÍTICO É PERDA DE FORÇA, POLÍTICA É GUERRA, SOFRIMENTO É FERIMENTO FÍSICO remetem ao chamado 'esquema de FORÇA', apontado por muitos estudiosos, entre eles Kövecses (2003), como um dos esquemas imagéticos básicos que estruturam o sistema conceptual humano.

A retomada da definição de metáfora como modelo cognitivo em que um domínio fonte mais concreto é utilizado para conceptualizar um domínio fonte mais abstrato permitiu 
constatar que Fernando Collor, ao escolher realizações linguístico-metafóricas às quais subjazem conceitos como COMBATE, SEGURAR (ALGO NAS MÃOS), PERDA DE FORÇA, GUERRA e FERIMENTO FÍSICO, todos envolvendo o exercício ou a perda de FORÇA, para metaforizar POLÍTICA e PODER, priorizou o domínio da FORÇA, entre tantos outros que poderia escolher, e revelou sua ideologia. A observação, num grau mais elevado de abstração em relação à metáfora discursiva, permitiu ainda chegar à chave conceptual PODER É FORÇA, um conceito que permeia todo o discurso de Fernando Collor, que aplica FORÇA ao exercer o PODER e é atingido por ela quando the arrancam o PODER à FORÇA.

O esquema imagético da FORÇA, fundamental na estruturação do sistema conceptual e na transmissão de ideologia, mostrou-se também significativo nas análises realizadas tendo em vista a questão cultural. De fato, na região nordeste, local de origem e atuação política da família Collor de Mello, tradicionalmente valoriza-se a FORÇA como qualidade humana positiva, especialmente quando se trata de um homem público, um político. Assim, é de se esperar que seu eleitorado se identificasse com esse valor, indiscutível para o povo dessa região.

Quanto à perspectiva argumentativa, é também possível afirmar, conforme propõe Charteris-Black (2004), que a seleção metafórica utilizada pelo interlocutor foi ainda motivada pelo propósito retórico da persuasão e, portanto, pela ideologia, neste caso de que PODER É FORÇA, pois convida a uma percepção partilhada dessa concepção, construindo uma visão de mundo em que o interlocutor é co-participante. No discurso político, planejado e produzido com objetivo persuasivo, é vital a aquiescência do interlocutor; portanto, é preciso utilizar-se de elementos linguísticos que se creia serem também valorizados pelo auditório, para que ocorra a persuasão, a adesão às ideias propostas.

Ao analisar a relação que Fernando Collor de Mello tem com a política e o poder, dadas as amostras, tanto de discurso falado como escrito do corpus que se investiga, foi possível observar o quanto o estudo sobre as metáforas discursivas pode contribuir para o aprofundamento de questões sobre cognição, influência cultural, transmissão de ideologia e habilidade argumentativa. Destaque-se ainda que proceder à análise a partir da interface entre estes campos revelou-se prática significativa para a compreensão do discurso político. 


\section{REFERÊNCIAS}

\section{BIBLIOGRÁFICAS}


AMOSSY, R. Da noção retórica de ethos à análise do discurso. In: AMOSSY, R. (org.), Imagens de si no discurso: a construção do ethos. Trad. Dilson Ferreira da Cruz, Fabiana Komesu e Sírio Possenti. São Paulo: Contexto, 2005.

AQUINO, Z. G. O. Conversação e Conflito - um estudo das estratégias discursivas em interações polêmicas. 1997. 367 f. Tese (Doutorado em Linguística) Faculdade de Filosofia, Letras e Ciências Humanas da Universidade de São Paulo, São Paulo.

Diálogos da mídia - o debate televisivo. In: Dino Preti. (Org.). Diálogos na fala e na escrita. São Paulo: Associação Editorial Humanitas, 2005, v. 7, p. 171-194.

ARISTÓTELES. Arte Retórica e Arte Poética. Trad. Antonio Pinto de Carvalho. Rio: Ediouro. S/d.

BORGES, J. L., FERRARI, O. Sobre a Amizade e Outros Diálogos. Trad. e Org. John O’Kuinghttons. São Paulo: Hedra, 2009.

CAMERON, L. Operationalising metaphor for applied linguistic research. In: L. Cameron \& G. Low (orgs.) Researching and Applying Metaphor. Cambridge: Cambridge University Press, 1999. p. 3-28.

CARVAlHO, J. M. Mandonismo, Coronelismo, Clientelismo: Uma Discussão Conceitual. Dados, Rio de Janeiro, v. 40, n.2, p. 229-250, 1997. (disponível em http://www.scielo.br/scielo.php?pid=S0011-52581997000200003\&script=sci_arttext, acesso em 09/08/2010)

CHARAUdEAU, P. Discurso Político. Trad. Fabiana Komesu e Dílson Ferreira da Cruz. São Paulo: Contexto, 2008. (Original: CHARAUDEAU, P. Le discours politique: les masques du pouvoir. Paris: Vuibert, 2005)

CHARTERIS-BLACK, J. Corpus Approaches to Critical Metaphor Analysis. London \& New York: Palgrave MacMillan, 2004.

Politicians and Rhetoric. The persuasive Power of Metaphor. Basingstoke \& New York: Palgrave-MacMillan, 2005.

CHEVAliER, J., GHEERBRANT, A. Dicionário de Símbolos: mitos, sonhos, costumes, gestos, formas, figuras, cores, números. Trad. Vera da Costa e Silva [et al.]. Rio de Janeiro: José Olympio, 2009. 996 p. (Original: CHEVALIER, J., GHEERBRANT, A. Dictionnaire des Symboles. Paris: R. Laffont S.A, Jupiter, 1982.)

CHILTON, P., ILYIN, M. Metaphor in political discourse: the case of 'the common European house'. Discourse and Society, London, v.4, n⿳⺈ 1, p.7-31, 1993.

CORREIA, M., LEMOS, L. S. P. Inovação lexical em português. (Cadernos de Língua Portuguesa 4). Lisboa: Colibri e Associação de Professores de Português, 2005.

DUCROT, O. O Dizer e o Dito. Trad. Eduardo Guimarães. Campinas: Pontes, 1987. 
FAIRCLOUGH, N. Discurso, mudança e hegemonia. In PEDRO, E. R. (Org.), Análise Crítica do Discurso - uma perspectiva sociopolítica e funcional. Lisboa: Caminho, 1997, p. 77-103. de Brasília, 2001.

Discurso e mudança social. Trad. Izabel Magalhães. Brasília: Editora Universidade Analysing Discourse: Textual analysis for social research. London and New York: Routledge, 2004 [2003].

FERREIRA, A. B. de H. Novo dicionário da Língua Portuguesa. Rio de Janeiro: Nova Fronteira, 1975. 1516 p.

GIBBS, R. W. The poetics of Mind - Figurative thought, language and understanding. Cambridge: Cambridge University Press, 1994.

GOODWIN, C., DURANTI, A. Rethinking context: an introduction. In: DURANTI, A., GOODWIN, C. (eds.) Rethinking context. Language as an interactive phenomenon. Studies in the social and cultural foundations of language n. 11. Cambridge: Cambridge University Press, 1992, p. 1-42.

GUIMARÃES, E. Figuras de Retórica e Argumentação. In: Retóricas de Ontem e Hoje. São Paulo: Humanitas Publicações/FFLCH-USP, 1997, p. 145-60

HOUAISS, A., VILLAR, M. de S. Minidicionário Houaiss da Língua Portuguesa. Rio de Janeiro: Objetiva, 2001. 481 p.

KERBRAT-ORECCHIONI, C. Análise da Conversação: princípios e métodos. Trad. Carlos Piovezani Filho. São Paulo: Parábola, 2006. (Original: KERBRAT-ORECCHIONI, C. La conversation. Éditions Du Seuil, juin 1996)

KÖVECSES, Z. Metaphor and Emotion: Language, Culture, and Body in Human Feeling. Cambridge: Cambridge University Press, 2003.

Press, 2005

Metaphor in Culture: Universality and Variation. Cambridge: Cambridge University Language, Mind and Culture: a Practical Introduction. New York: Oxford University Press, 2006.

Metaphor: A Practical Introduction. New York: Oxford University Press, 2010.

KRESS, G., HODGE, R. Language as Ideology. London: Routledge, 1993.

LAKOFF, G. Woman, Fire, and Dangerous Things: What Categories Reveal about the mind. Chicago: University of Chicago Press, 1987.

LAKOFF, G. The Invariance Hypothesis: is abstract reason based on image-schemas? In: Cognitive Linguistics. V. 1, Issue 1, 1990, p. 39-74. 
LAKOFF, G., JOHNSON, M. Metáforas da Vida Cotidiana. Trad. Mara Sophia Zanotto. Campinas, SP: Mercado de Letras; São Paulo: EDUC, 2002. (Original: LAKOFF, G. \& JOHNSON, M. Metaphors we live by. Chicago/London: The University of Chicago Press, 1980.)

Philosophy in the Flesh: The Embodied Mind and its Challenge to Western Thought. New York: Basic Books, 1999.

MELLO, F.C.M., Veja, São Paulo, ed. 2172, ano 43, n. 27 de 07 de julho de 2010. Panorama, Veja Essa, p. 60. Reprodução de declaração.

MEYER, M. A retórica. Trad. Marly N. Peres. São Paulo: Ática, 2007.

MOSCA, L. do L. S. Velhas e Novas Retóricas: convergências e desdobramentos. In: Retóricas de Ontem e Hoje. São Paulo: Humanitas Publicações/FFLCH-USP, 1997, p. 17-54.

OSAKABE, H., Argumentação e Discurso político. São Paulo: Martins Fontes, 1999.

PALMA, D.V. A Leitura do Poético e as Figuras de Pensamento de Oposição: Caminhos e Descaminhos de Paradigmas na Modernidade. 1998. Tese (Doutorado em Linguística Aplicada ao Ensino de Línguas) Pontifícia Universidade Católica de São Paulo.

PERELMAN, C., OLBRECHTS-TYTECA, L. Tratado da Argumentação: a Nova Retórica. $2^{a}$ ed. Trad. Maria Ermantina Galvão. São Paulo: Martins Fontes, 2005. (Original: PERELMAN, C. \& OLBRECHTS-TYTECA, L. Traité de l'Argumentation. La nouvelle rhetórique. Bruxelles: Éditions de l' Université de Bruxelles, (1958). 1983.)

PLANTIN, C. A Argumentação: História, teorias, perspectivas. Trad. Marcos Marcionilo. São Paulo: Parábola, 2008. (Original: PLANTIN, C. L'Argumentation. Paris: Presses Universitaires de France, 2005)

PRETI, D. e URBANO, H. (Org). A linguagem falada culta na cidade de São Paulo. São Paulo: T. A. Queiro, Fapesp, 1990. v. 4.

REBOUL, O. Introdução à Retórica. Trad. Ivone Castilho Benedetti. São Paulo: Martins Fontes, (1998 [1991]). (Original: REBOUL, O. Introduction à la Rhéthorique: Théorie et Pratique. Paris: Presses Universitaires de France, 1991)

RESENDE, V. M., RAMALHO, V. V. S. Análise de Discurso Crítica. São Paulo: Contexto, 2006.

RICOUER, P. A metáfora viva. Trad. Dion Macedo. São Paulo: Loyola, 2000.

SANTOS, R. P. dos. A construção da memória como elemento da repressão e poder na Argentina peronista. Dimensões - Revista de História da Ufes, Vitória, vol. II, n.13, jul/dez 2001, p. 163-173. 1 (disponível em http://www.ufes.br/ppghis/dimensoes/artigos/Dimensoes13_RaquelPazdosSantos.pdf, acesso em 17/08/2010)

SARDINHA, T.B. Metáfora. São Paulo: Parábola, 2007. 
SILVEIRA, R. C. P. da. Implícitos Culturais: ideologia e cultura em expressões linguísticas do português brasileiro. In: BASTOS, N. B. (Org.) Língua Portuguesa em Caleidoscópio. São Paulo: EDUC, 2004, p. 143-158.

TOULMIN, S. E. The uses of Argument. Cambridge: Cambridge University Press, 1958.

ULLMANN, Stephen. Semântica: uma introdução à ciência do significado. Lisboa: Fundação Calouste Gulbekian, 1964.

van DIJK, T. A. Semântica do discurso e ideologia. In PEDRO, E. R. (Org.), Análise Crítica do Discurso - uma perspectiva sociopolítica e funcional. Lisboa: Caminho, 1997, p. 105-168.

T. A. Discurso e Poder. São Paulo: Contexto, 2008.

VILELA, M. Metáforas do Nosso Tempo. Coimbra: Almedina, 2002.

WODAK, R. Do que trata a ACD - Um resumo de sua história, conceitos importantes e seus desenvolvimentos. Revista Linguagem em (Dis)curso, Tubarão, v.4, n.especial, 2004, p. 223243. Disponível em:

<http://www3.unisul.br/paginas/ensino/pos/linguagem/0403/10.htm> Acesso em 22 nov. 2008.

WYSOCKI, B. Interação face a face: um estudo das estratégias discursivas na reconstrução da imagem. 2007. 166 f. (Mestrado em Filologia e Língua Portuguesa) Faculdade de Filosofia, Letras e Ciências Humanas da Universidade de São Paulo, São Paulo. Também disponível em: http://www.teses.usp.br/teses/disponiveis/8/8142/tde-05052008-153601/, acesso em 08/09/2010. 
ANEXOS 


\section{ANEXO A}

Transcrição de uma propaganda eleitoral da campanha a presidente da República em 1989 e a sua reprodução em mídia digital, com a duração de $1 \mathrm{~m} 38 \mathrm{~s}$, tal como foi veiculada pelas emissoras de televisão durante o horário eleitoral gratuito. A transcrição, necessária em razão de se tratar de texto falado, foi feita segundo as normas instituídas pelo projeto NURC/SP, também relacionadas entre os anexos (ANEXO 8). O vídeo da referida propaganda foi recuperado por meio eletrônico através do arquivo de imagens acessado em 02 de março de 2010 pelo link: http://www.youtube.com/watch?v=tVAPdnNOVxU

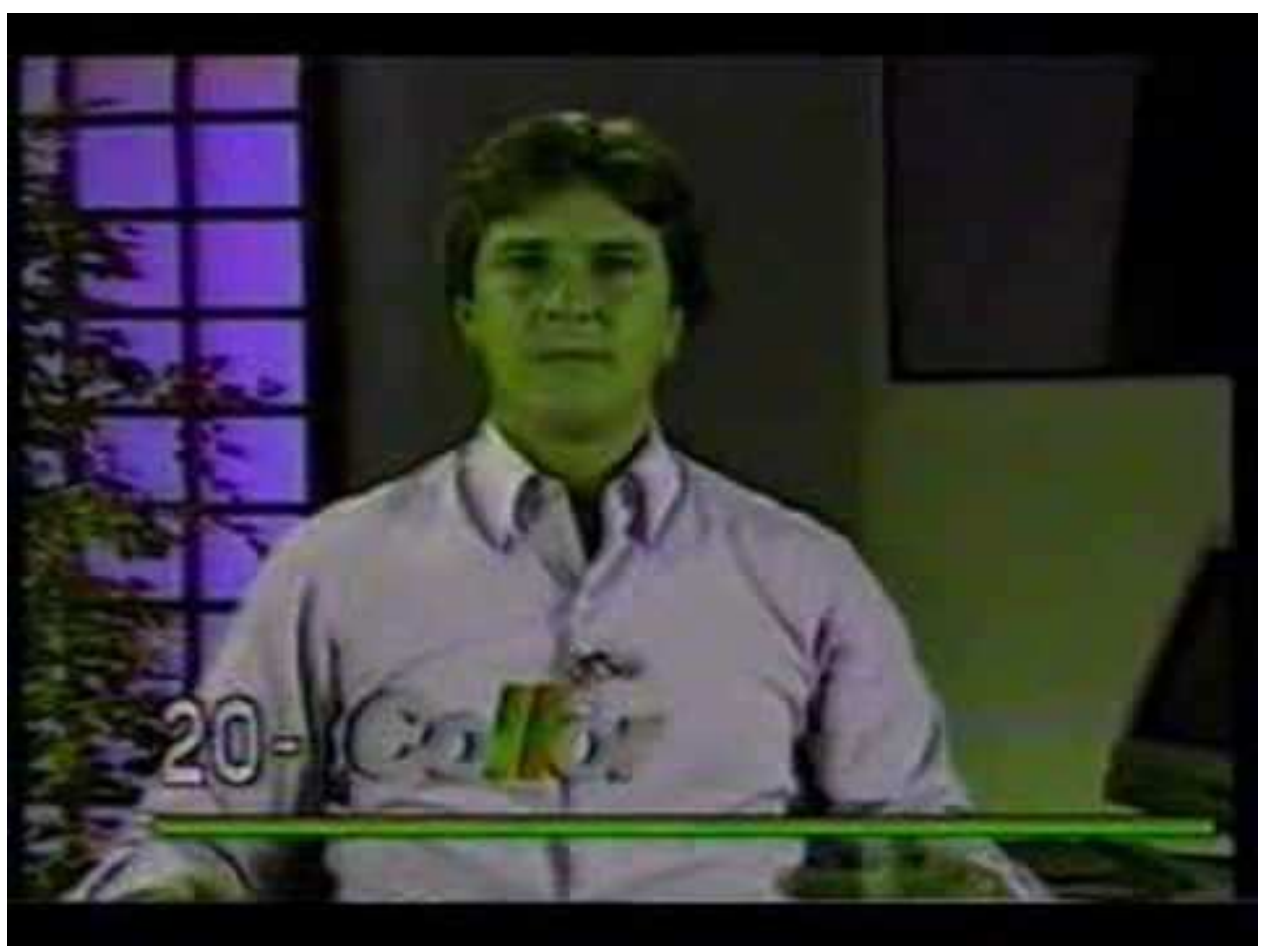


(...) com você professora professor médica médico que educa os nossos filhos que toma conta da sa-ú-de dos nossos filhos e não é reconhecido com um salário DIGno... com voCE militar das forças armadas e das polícias... que cuidam da nossa segurança... com você

5 servidor federal que cumpre com a sua obrigação... e é tão mal remunerado... será que é justo... você ganhar tão pouco?... será que é justo um apadrinhado dos poderosos ganhar até cinQUENta salários para ficar sentado no seu TROno de maraJÁ... sem fazer NAda... e voCÊ que dá duro OIto horas por dia ... ganhar um salário que não dá

10 sequer para pagar a mensalidade escolar dos seus filhos? ... foi para acabar com esta pouca vergonha... minha gente... que lutei TANto em Alagoas... e iniciei uma cruzada que chegou ao Brasil inTEIro... a CAça aos maraJÁS... você sabe ... meu amigo... que o serviço público não é para marajás ... é para gente como você que está me ouvindo ... com a consciência tranquila de quem cumpre co/a sua obrigação... é esta injustiça... uns ganhando TANto e outros TÃO pouco ... que nós vamos corrigir quando eu chegar à Presidência da República... você POde estar certo ... meu amigo servidor... que eu não vou demitir ninguém que trabalha... agora... marajá ... corrupto e boa vida... esses vão pra rua...mas estes... não são funcionários públicos...estes são turistas... com o dinheiro que se desperdiça HOje com os marajás nós vamos ISSO SIM... pagar melhores salários ao funcionário público que REalmente trabalha...aGOra minha gente... cheGOU a nossa vez 


\section{ANEXO B}

Reprodução do discurso de posse no Parlatório, um equivalente resumido do discurso de posse como Presidente no Congresso Nacional, proferido no local denominado Parlatório do Palácio do Planalto, um anexo externo do Palácio, em Brasília, em 15 de março de 1990, cuja transcrição foi recuperada no site pessoal de Fernando Collor de Mello, em 27/02/2010, pelo link http://www.collor.com/discursos1990_002.asp . O referido discurso foi reproduzido tal como se encontra no site citado, inclusive as incorreções.

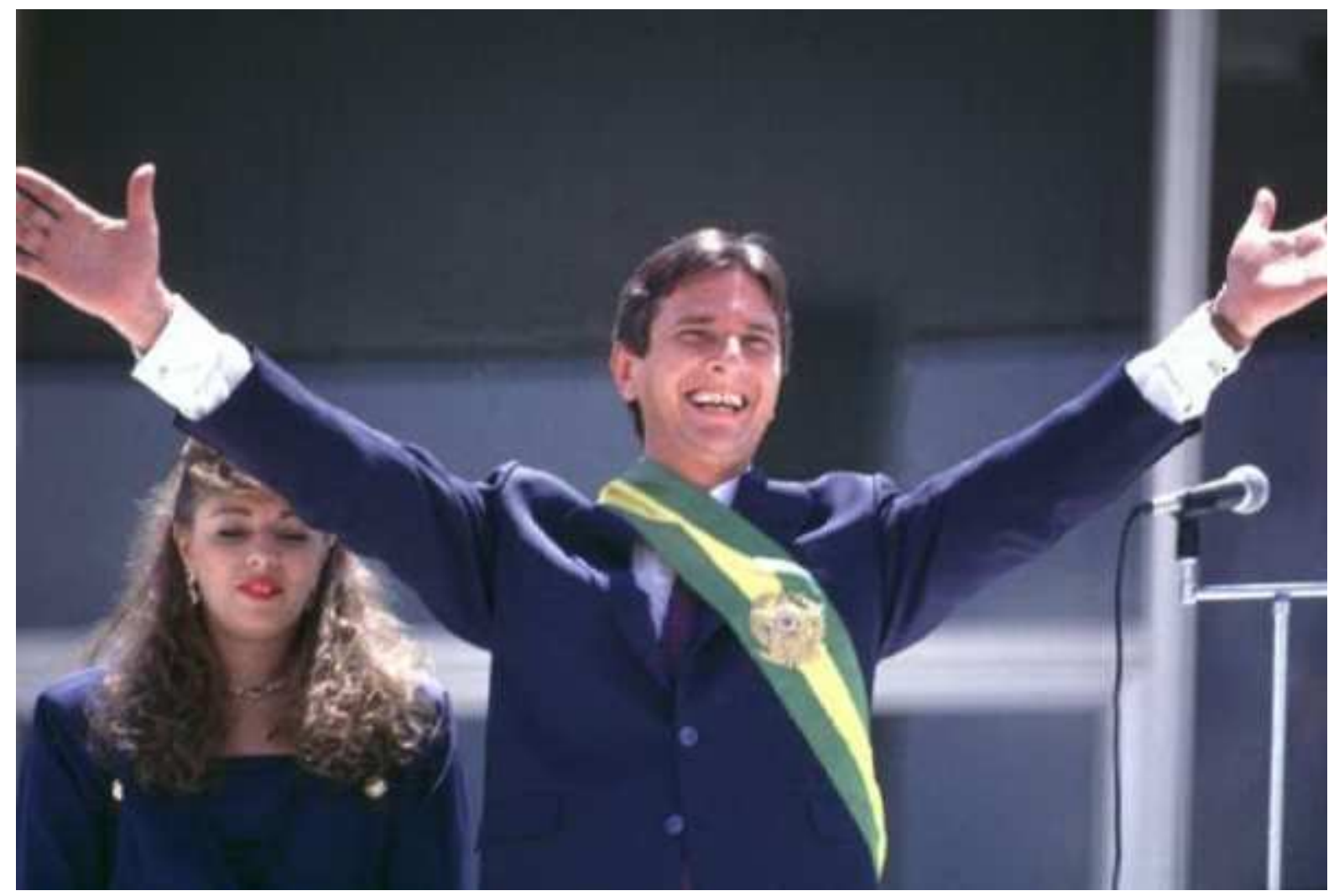

Posse de Fernando Collor de Mello 


\section{Gollor}

\section{DISCURSOS DURANTE A PRESIDÊNCIA}

Discurso pronunciado por sua Excelência o Senhor Fernando Collor, Presidente da República Federativa do Brasil, no Parlatório do Palácio do Planalto.

Brasília, em 15 de março de 1990. Minha gente amiga do Brasil,

A transição democrática se completa neste instante com a posse de um Presidente da República eleito pelo voto direto da maioria do povo brasileiro.

Todos nós temos compromissos com a democracia tão duramente conquistada. Temos compromissos com a justiça social, temos compromissos com o desenvolvimento, com a liberdade e com o progresso que haverá de nortear os rumos deste País, a partir deste 15 de março.

Quero, neste instante em que recebo a faixa presidencial,símbolo da chefia do Estado e do Governo da República Federativa do Brasil, voltar o melhor do meu pensamento e a maior das minhas preocupações para a imensa maioria de brasileiros quem eu devo esta conquista democrática: aos descamisados, aos pés descalços, àqueles que querem justiça social no País, para poder viver condignamente.

Chegamos neste dia, depois de uma luta que incandesceu este País,quando as paixões estavam livres, o discurso garantido por uma Constituição e o processo democrático assegurado pelas forças vivas da sociedade brasileira. E chegamos para cumprir uma missão, para cumprir um mandato que não pertence a uma pessoa, na figura do Presidente da República, que não pertence somente a um partido, mas pertence a todo o Brasil,que deseja estar unido neste momento, para que possamos retirar a Nação brasileira desta angústia e do trágico cotidiano em que se debatem milhões e milhões de brasileiros.

Quero, neste instante, jurar a vocês, diante do altar de minhas conviç̧ões, de que haverei, conjuntamente com o Congresso Nacional, com o Poder Judiciário, respeitando a independência e a harmonia dos Poderes, juro a vocês, diante do altar das minhas convicções, que, ao lado do povo brasileiro, da sociaedade civil organizada, nós haveremos sim, minha gente, de reconstruir o nosso País, para recuperarmos a confiança no seu verdadeiro destino.

Volto, também neste momento, o meu pensamento para a minha querida Alagoas, para o meu Nordeste, para todos os recantos deste País, de Norte a Sul, para aqueles que sofrem hoje com o salário baixo, com a falta de ensino, de saúde, com a falta até de esperança. Volto os meus olhos e as minhas preocupações para vocês e me comprometo mais uma vez a dar o melhor de mim, a dar a minha saúde e a minha própria vida, se necessário for, para cumprir rigorosamente o nosso programa de governo.

Que Deus ajude o Presidente da República ! Que Deus ajude os seus Ministros!

Que Deus ajude o nosso Povo, para que nós encontremos, definitivamente, a trilha do crescimento econômico e da justiça social!

Obrigado minha gente, até um outro dia. 


\section{ANEXO C}

Reprodução do relato denominado "Crônica de um golpe", referente à saída do governo, na ocasião do processo de Impeachment, retirado do site pessoal de Fernando Collor de Mello, em 27/02/2010, pelo link http://www.collor.com/livro.asp. Também há uma versão praticamente igual a esse texto publicada na Revista Veja, exemplar número 1515 , de $1^{\circ}$. de outubro de 1997, em reportagem que teve o título de "A voz do vencido", em que ele apresenta o segmento como sendo o primeiro capítulo do livro Crônica de um Golpe - A Versão de Quem Viveu o Fato, que ele supostamente estaria escrevendo sobre sua passagem pela Presidência e memórias sua infância, família e carreira. Preferiu-se a versão do site pessoal. As fotos abaixo fazem parte da referida reportagem.

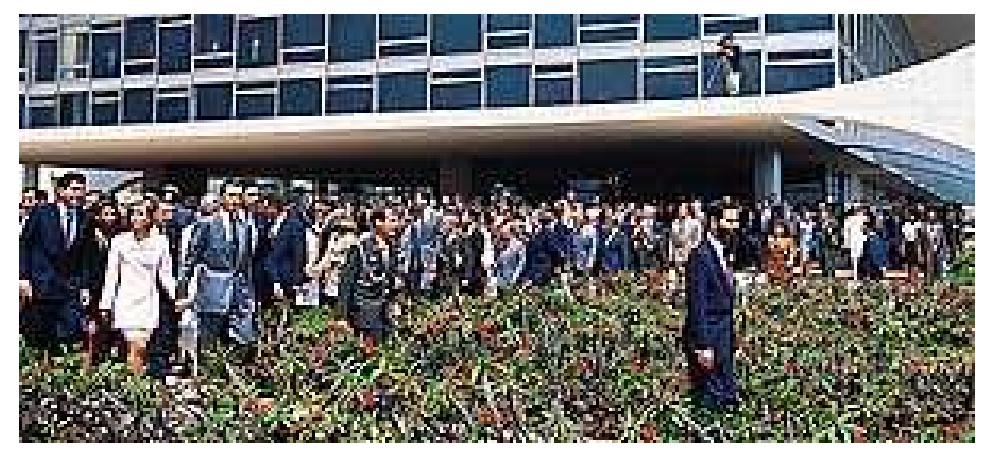

A saída de Collor e Rosane do Palácio

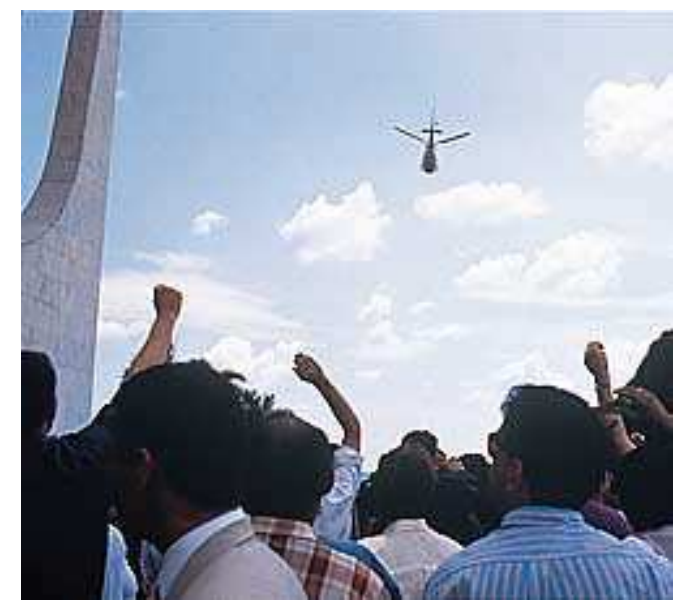

Voo final de helicóptero 


\section{CRÔNICA DE UM GOLPE \\ A versão de quem viveu o fato \\ Primeiro capítulo}

Os meus funcionários do Palácio do Planalto foram protagonistas e testemunhas de todo o processo. Alguns - mais experientes - certamente puderam prever que logo a traição bateria à porta do meu gabinete, sobretudo depois que fiz alterações necessárias no ministério e acolhi, na ante-sala, a colaboração de figuras que se aproximam dos governantes, sejam quais forem, porque não sabem sobreviver senão à sombra do poder. Esses anônimos funcionários acompanharam apreensivos o dia angustiante de 29 de setembro de 1992, a data de votação do pedido de impeachment no Congresso Nacional. Foi um dia tomado por articulações, dúvidas e certezas. Votos certos a meu favor, até mesmo de parlamentares amigos, foram de súbito revertidos depois de conversas reservadas, certamente gratificantes, com os articuladores golpistas. O incessante entra-e-sai do meu gabinete foi diminuindo à medida em que caía a tarde e avançava a sessão do Congresso, acompanhada por manifestantes concentrados inclusive no lado de fora daquela Casa, a que servimos meu avô Lindolfo Collor, meu pai Arnon de Mello e eu.

\section{Fez-se escuro.}

Com a ajuda de um pequeno controle remoto, acendi apenas as lâmpadas de halogênio direcionadas sobre a minha mesa. Completamente sob penumbra, foi invadido pela quietude o amplo gabinete que me acolheu por quase mil dias, desde 1990, e de onde governara com a certeza de que fazia as melhores escolhas para o meu País e a minha gente. Pedi para não ser incomodado. Fiquei só. Enquanto no Congresso a traição se manifestava e o golpe se consolidava, no meu gabinete nada se ouvia.

\section{0 silêncio era total.}

Nenhum aparelho de rádio ou televisão ligados, o telefone emudecido. Sequer murmúrios das duas saletas ao lado, onde estavam ajudantes de ordem e assessores mais íntimos. Durante alguns minutos, talvez trinta, quarenta, rendi-me às recordações de minha infância, da adolescência no Colégio São José, no Rio de Janeiro, dos conselhos de meu pai ( "no exercício da política, meu filho, é fundamental três coisas - paciência, paciência, muita paciência", dizia-me), das lutas em Alagoas, do processo arrebatador que me levou ao Planalto, da agonia de minha mãe no leito do hospital, da expressão assustada dos meus filhos, das decisões que tomei naquele gabinete finalmente deserto, escuro, silencioso.

Inerte, à janela, contemplando o nada, tentava ouvir o silêncio. Mas o que ouvi, de repente, foi um ruído surdo, um rumor de multidão, que saía do plenário da Câmara dos Deputados, chegava aos manifestantes e logo se espalhava, misturando-se a buzinas de automóveis. Percebi naquele momento que o impeachment havia sido aprovado. Continuei só, em pé, imóvel.

\section{Era o fim.}


Dali a instantes, o secretário-geral da Presidência da República entrou no gabinete e, às minhas costas, disse com voz clara, triste e respeitosa:

-Senhor Presidente, a votação acabou.

Voltei-me para ele e o dispensei da necessidade de fazer a comunicação do resultado da votação:

-Já sei Marcos. Não temos mais o que fazer. Vamos para casa.

Parecia um dia qualquer, mas era o último. Senti as mãos de Rosane entrelaçarem a minha, apertando-a vigorosa e carinhosamente. Sem mesmo olhar em seus olhos, imaginei-a assustada. As mãos firmes estavam frias, mais do que impõe o clima de Brasília nos outubros secos de manhãs geladas. Ela havia chegado minutos antes, perto das 10h, depois de o Chefe do Gabinete Militar (General Agenor Homem de Carvalho) ordenar ao hesitante piloto que o helicóptero fosse buscá-la em casa. Estava especialmente bonita naquela manhã, no tailleur rosa, simples mas elegante, e mantinha os cabelos curtos, emoldurando os olhos claros, naturalmente abertos e desafiadores. Havia outras pessoas no gabinete, mas por um momento senti-me absolutamente a sós com ela. Não me passava pela cabeça que ficaríamos assim, sozinhos, dali em diante, por um longo período. Convencerame de que logo estaríamos de volta, após o triunfo da verdade.

60 De mãos dadas, deixamos o gabinete para entrarmos no pequeno reservado, onde muitas vezes refleti sobre as decisões necessariamente solitárias, para dali chegarmos ao salão do lado, onde aguardava um numeroso grupo de jornalistas, parlamentares, funcionários e até mesmo alguns curiosos. Diante da porta que nos separava daquelas pessoas, parei um momento para uma breve oração, concluindo quase com um sussurro: "dai-nos forças, meu Deus, para que superemos tudo isso com dignidade e fé". Ao abrir os olhos, encontrei os de Rosane a refletir uma serenidade espantosa. Afagou-me a mão mais uma vez. Em significativo silêncio, ela parecia dizer: "tudo bem, vamos enfrentar isso juntos". De modo algum parecia assustada, como imaginei antes. Ao contrário. Permanecia calma. Acho que nela se alevantara a tal valentia sertaneja, própria da minha gente do Nordeste. Rosane carregava uma dignidade da qual me orgulharei sempre.

À chegada do helicóptero na Casa da Dinda, horas antes, dera-me conta da rotina que se estabelecera no início do governo, 133 semanas antes, exatos 932 dias. Despedi-me com um beijo, lembrando que a aguardaria no Palácio do Planalto às dez horas da manhã daquele 2 de outubro, e acenei, como sempre fazia, para algumas pessoas que comigo trabalhavam na Casa da Dinda. À medida em que me aproximava do Planalto, sobrevoando a quietude da paisagem de Brasília e as águas do Paranoá, invadiu-me um certo sentimento de alívio, como se me encaminhasse para a última bataIha, a derradeira volta de uma corrida, o tempo final de uma partida.

"Vou finalmente descansar um pouco, retemperar as forças e partir para a luta", confortei-me, contemplando do alto da Praça dos Três Poderes, enquanto se realizava o procedimento de pouso. 0 percurso fora vencido em pouco mais de dois minutos. No terceiro andar do Planalto, encontrei o gabinete já com as gavetas 
vazias e sem as condecorações, mantidas antes em pequenos mostradores de madeira e vidro.

- Está tudo encaixotado, Senhor Presidente, disse-me alguém.

Símbolo de uma atitude moderna frente à administração pública, o computador que me servia estava finalmente emburrecido, sem memória nem saber. As fotografias de minha mulher e dos meus filhos desapareceram da mesa, assim como as imagens de Nossa Senhora da Conceição e de S. Francisco de Assis, esta um presente de Frei Damião de Bozanno. 0 gabinete voltara a ser frio e impessoal.

Os funcionários da Secretaria Geral da Presidência da República quiseram apresentar as suas despedidas. Estavam emocionados, com expressões carregadas, cabisbaixos.

Recebi-os no gabinete com um bom humor que os surpreendeu:

- Por que vocês estão aqui ?

Ficaram desconcertados, alguns sorriram, outros se abraçaram a mim, chorando.

\section{A saída}

100 O chefe do serviço de segurança ( coronel Darke Figueiredo) ponderou ao seu superior imediato - o chefe do Gabinete Militar - e logo o general Agenor trouxe a apreensão dos militares:

- Senhor Presidente, acho que seria mais seguro sair do Palácio pela garagem, no subsolo. Continuam chegando ônibus com manifestantes, que parecem muito agressivos, vão fazer barulho.

Compreendi a preocupação, mas recusei:

- Eles não metem medo em ninguém, general, eu os conheço. Vou sair pela porta da frente.

Não me seria possível, nem se o desejasse, deixar o Palácio pela garagem. $\mathrm{Na}$

110 realidade, desde cedo, ainda na adolescência vivida alí mesmo em Brasília, havia aprendido lições inestimáveis de coragem e destemor, que balizam o meu comportamento diante de ameaças assim. Enfrentei sem hesitar, no braço e inutilmente ( porque acabamos todos detidos), nos anos 60 , os policiais que invadiram a biblioteca da Universidade de Brasília ocupada por nós, estudantes do

115 Ciem ( o histórico Centro Integrado de Ensino Médio) e da própria UnB, que protestavam contra o acordo MEC-Usaid, assim como, mais tarde, desafiei os assassinos de aluguel que quiseram intimidar minha candidatura ao Governo de Alagoas e os intolerantes que tentaram barrar a nossa caminhada, na campanha presidencial. Como Presidente do meu País, eu não negaria à Nação as cenas da 120 despedida, ainda que carregada de emoção e melancolia. Nem deixaria de enfrentar aqueles tolos que tentavam dar legitimidade a um ato de força. 
A história dos homens se escreve com palavras vitoriosas, e se agora posso relembrar aqueles momentos com o distanciamento do tempo, é porque a vitória, no final, seria minha. Uma vitória contra todas as manobras engendradas e deflagradas em praticamente todo o território nacional pelas mesmas forças retrógradas que mantêm o Brasil neste anacronismo cruel, cuja expressão mais perfeita é certamente a perversa distribuição da renda. Foi com este estado de espírito que observei, através da vidraça, as figuras tristes de manifestantes que agiam como marionetes sem vontade própria, massa de manobra fiéis à velha máxima de mudar algo, qualquer coisa, para não mudar coisa alguma.

Dei instruções severas para evitar repressão policial, à minha saída do Palácio:

-A intolerância é o desespero dos fracos.

Conhecia-os mesmo, como dissera quase sem perceber ao general Agenor. Os que se aproximavam do Planalto, naquele momento, tinham a mesma consistência

135 invertebrada dos que enfrentamos - e vencemos - na célebre campanha presidencial de 1989. Recordei até com certa saudade daqueles tempos aquecidos da campanha, quando adversários tentavam intimidar a minha candidatura com violência física.

\section{A campanha}

140 Em Niterói, bela cidade do Rio de Janeiro, nos bravos dias de campanha, manifestantes ofegantes e suados, "em nome da democracia", deram os braços para impedir a passagem de uma centena de caminhantes que me seguiam os passos, em direção ao clube Canto do Rio, para falar ao povo. Imaginavam que recuaríamos, amedrontados. Continuamos caminhando no mesmo sentido, sem

145 hesitar. 0 encontro - talvez o confronto - seria inevitável. Enquanto caminhávamos, as agressões se sucediam. Como os gritos eram inúteis, porque não nos faziam parar; iniciaram-se as agressões físicas contra crianças e mulheres que nos acompanhavam vestindo camisetas e portando bandeiras de campanha. Um senhor de seus setenta e poucos anos foi obrigado a ajoelhar-se com violência, para que

150 Ihe arrancassem a camisa collorida. Como numa batalha, defendíamos os nossos como podíamos, enquanto a caravana seguia imparável, a pé, para o confronto com aqueles que fechavam a rua adiante, de braços dados. Segui à frente, disposto a enfrentá-los. Logo atrás, soube depois, vinham apenas três assessores, Luíz Amorim, Dário César, Claúdio Humberto, este último atingido por uma pedrada que

155 Ihe valeu sete pontos no rosto. A menos de dois metros do choque, os valentões romperam o "cordão", acorvadados, e passamos. Eles perceberam que já não havia mais crianças, mulheres e velhos a enfrentar.

\section{E correram.}

Gente que só vê o que quer publicou uma fotografia minha, nesse episódio, com punho cerrado e braço erguido sustentando que se tratava de um gesto menos cordial, a popular "banana". Ainda que fosse, teria sido uma reação natural, mas o importonte é que a expressão no rosto revelava a intenção de não me deixar intimidar. A boca aberta indicava que eu gritava algo de que nem me lembro, mas na certa teria sido um grito de guerra; do contrário, estou certo de que não teríamos chegado ao clube. 
Militantes do atraso e de um fracasso muito próprio, manifestantes que atiram pedras e tentam impedir a livre manifestação não passam de gente que não pode mudar de idéia e por isso não quer mudar de assunto. E gritam, xingam, ofendem, como fanáticos que professam ódio irracional de quem não possui opinião e recusa a novo, o nascimento do futuro. Não sabem que a violência política é cúmplice da incompetência e criatura do poder absoluto.

Às 9h35 concluí a mensagem que decidira divulgar agradecendo à Nação, aos amigos e colaboradores, às classes trabalhadoras e produtoras e a todos os setores políticos - mesmo àqueles instalados entre os conspiradores, na oposição e fora 175 dela, estes últimos funcionalmente próximos, bem próximos de mim - pela constante presença no processo político. Devia esse gesto aos brasileiros.

Escrevi sem qualquer sentimento de mágoa, com intenção de falar ao coração do povo, assegurando-Ihe a convicção - ingênua, hoje reconheço - de que logo emergiria a verdade e todos os equívocos seriam desfeitos. Subestimei, naquele momento, a ação dos que não pretendiam provar coisa alguma, mas apenas tomar o poder, numa conspirata sem voto ou vergonha, afastando quem se colocara contra os seus interesses.

Com clareza e perseguindo um tom elegante, propriedades tão escassas naqueles dias, procurei assegurar na mensagem que, em nenhum momento, deslustrei a dignidade das funções que exercera, nem me afastei, milímetro sequer, da missão de transformar o País no exemplo de esforço para a conquista da modernidade com compromisso social, a que me propunha desde o início de tudo.

Considerei útil recordar, no texto, que foram por mim determinadas as averiguações, em todas as instâncias subordinadas ao Presidente da República, que resultaram na aceitação do pedido de impeachment, a começar pelo ofício que encaminhei ao Ministério Público, chefiado pelo procurador Aristides Junqueira, que havia sido por mim reconduzido ao posto. Com esta nomeação, quis dar uma demonstração de que nada tinha a temer, porque o chefe do Ministério Público, por suas ações, já havia deixado bem claro a sua má vontade em relação ao governo.

195 De posse do ofício através do qual eu determinava rigorosas investigações, o procurador geral cometeu inúmeras violências, talvez do tamanho e da intensidade cometidas por ele quando colaborava com a tortura de presos políticos durante o regime militar.

Pouca gente sabe que Aristides Junqueira foi listado entre os torturadores dos 200 tempos da ditadura, nas páginas 192 e 193 do livro Brasil: Nunca Mais, prefaciado pelo arcebispo de São Paulo (Dom Evaristo Arns), que denuncia: "A aceitação, como elemento de prova, de depoimentos colhidos em delegacias ou ambiente militar [observação: pela tortura], que colidia com a tradição jurídica brasileira, foi avalizada na época por um ativo procurador da Justiça Militar, chamado Aristides

205 Junqueira, atual procurador-geral do Republica". Ali evidencia-se um viés desconhecido do caráter do sestroso procurador Cuja aparência soturna e reservada escondia, no fundo, a alma mutilada pela angústia e a consciência pesada pelo suplício que infligiu às suas vitímas. Suas ações contra mim pareciam querer apagar da lembrança coletiva o sangue derramado e a dor infinita gerada pela sua atitude no seio da família brasileira. 
Certamente, do costume que carregou consigo desde aquela época, resultou a tentativa de incriminar-me, movido muito mais pelo seu desejo insaciável de apagar seu triste passado do que pelo eventual apego à verdade e à Justiça.

\section{O Golpe}

215 Antes de sinalizar para que a porta de acesso ao salão ao lado fosse finalmente aberta, chequei o último detalhe:

- Major, o senador já chegou ? - perguntei ao eficiente Chefe da Ajudância de Ordens ( Fernando Azevedo e Silva ), que se fez amigo. Referia-me ao primeiro secretário do Senado Federal (Dirceu Carneiro) que chefiava a comissão de

220 senadores designada para entregar-me o comunicado oficial da abertura do processo de impeachment.

- Está no corredor, Senhor Presidente, à espera de ser chamado para a solenidade. "Solenidade". De fato a expresão era adequada. Quis que fosse assim, um momento solene. Reafirmação de civilidade. Recusei assinar em particular o "recibo" da citação, como sugeriu o secretário-geral da Presidência da República.

- A Nação tem o direito e até o dever de testemunhar esse ato de força, Marcos.

Os brasileiros teriam a oportunidade de presenciar a culminância de um golpe parlamentar inédito na nossa História. Esse testemunho certamente seria valioso na compreensão futura do episódio. Foram necessários dias de intensa negociação,

230 entre a votação de 29 de setembro e aquele 2 de outubro, véspera das eleições municipais de 1992, para que eu pudesse convencer a todos -especialmente os meus- da necessidade de realizar uma transição adu1ta. O Brasil merecia. Embora vítima de um movimento golpista, quem chega à Presidência da República pela força do voto, não tem o direito de sair do Palácio senão pela porta da frente, com a cabeça erguida, e era exatamente isso o que eu pretendia fazer.

\section{O Clima de tristeza}

Jamais repetiria o gesto de outros presidentes inconformados com o destino, deixando o Palácio do Planalto pelas portas dos fundos. 0 último presidente militar por exemplo, o general João Figueiredo, para não assistir ao júbilo do próprio

240 sucessor ( José Sarney), por quem não tinha o menor respeito, cometeu o equívoco de abandonar o Palácio pelos fundos. Senti-me obrigado a concordar que, no exercício do poder, Figueiredo aprendera a avaliar bem as pessoas. 0 " traidor oportunista ", que tanto indignara Figueiredo, cinco anos, uma abafada CPI da Corrupção, dezenas de escândalos e quase $100 \%$ de inflação mensal depois, temia sofrer constrangimentos ao sair do Planalto. Devia ter lá suas razões, mas em nome da concórdia optei por visitar o último presidente sem voto da República, para ajudá-lo a sair de um pesadelo que o atormentava havia meses. Autorizei providências para uma visita minha ao Pericumã, onde se refugiara para o carnaval daquele ano. Deixamos o "Bolo de Noiva"- prédio que ocupamos entre janeiro e helicóptero da FAB. 
A visita foi cordial e oproveitei a oportunidade para solicitar- Ihe a nomeação do presidente do Banco Central no meu governo e decretar feriado bancário necessário à adoção do nosso plano econômico - no que fui prontamente atendido.

255 O cuidadoso chefe do cerimonial (Embaixador Osmar Chohfi), à minha frente, abriu a porta que separava o gabinete do salão ao lado e anunciou:

- 0 Senhor Presidente da República.

0 ambiente, ali, estava carregado, denso, consternado, com a presença de alguns poucos amigos, entre os quais o senador Ney Maranhão, sempre presente nos

260 momentos mais difíceis, o senador Odacir Soares, nem todos os ministros ( Estiveram ausentes ao último ato os ministros Reinhold Stephanes, Antonio Cabrera, Pratini de Morais, Adib Jatene e Affonso Camargo ), outros parlamentares, funcionários dos quais me despedi antecipadamente e jornalistas, que saboreavam o momento grave. Tudo parecia organizado segundo as minhas determinações.

265 Orientara ao Secretário de Imprensa a tomar providências para permitir o acesso dos jornalistas e a transmissão direta pelas emissoras de rádio e televisão. Decidi que a contra-fé solene à citação do Senado Federal deveria ser realizada no salão contíguo ao gabinete presidencial, antes utilizado para reuniões ministeriais e depois restrito a atos solenes, depois da construção do conhecido "salão oval", no segundo andar do Palácio. Com isso, pretendi registrar para a História que o Presidente da República acatava com serenidade a decisão do Parlamento e que, civilizadamente, recusou todas as tentações para evitar aquele ato ou mesmo, antes, de fechar o Congresso Nacional, como queriam alguns e como fizera um país vizinho com surpreendente apoio popular.

275 Alegavam os defensores desse ato de força que o Congresso era um enorme balcão de negócios e que o povo apoiaria qualquer iniciativa nesse sentido. "A Câmara dos Deputados é presidida por um corrupto, é preciso denunciar isso ao País", exemplificavam.

Um ano depois, receberia a visita do cineasta Luiz Carlos Barreto. Depois de 280 conversarmos longamente sobre as circunstâncias de minha saída do governo, o premiado produtor de O Quatrilho, bem humorado, exclamou:

- 0 que este País precisa é de um ditador!

Inicialmente não entendi aquela posição de alguém a quem sempre considerei um combatente da Democracia. Mostrei o meu espanto e logo ele se apressou em corrigir:

- Mas eu sou um democrata!

- Então o que quis dizer com "ditador"?

- Um ditador eleito pelo voto popular. Alguém que fizesse a sua campanha avisando na televisão: Se eleito Presidente da República, vou fechar o Congresso.

Diante da minha perplexidade, Luis Carlos Barreto, sempre divertido, concluiu:

- Se o senhor fizesse uma campanha assim, seria eleito com uma votação extraordinária! 
Sempre reagi à idéia com severidade. Aos mais impacientes lembrei que a banda podre do Congresso seria desmascarada mais cedo ou mais tarde. De fato, não demoraria muito. 0 escândalo do Orçamento, que logo se seguiu, revelaria alguns dos "anões " que efetivamente saquearam a Nação e, entre os acusados, encontravam-se os mesmos "virtuosos" que me ofendiam em público, pediam benesses em particular e, frustrados, atacavam o governo. Autoproclamado o "muso do impeachment ", responsável fundamental pela votação viciada que resultou com a minha renúncia à Presidência da República e pela violência cometida contra a Constituição, o presidente da Câmara dos Deputados (Ibsen Pinheiro) estava entre os corruptos mais notáveis, pilhados pela CPI do Orçamento. Suas contas bancárias confirmariam as denúncias que levaram à cassação do seu mandato.

305 Como uma Nação adulta, uma das mais desenvolvidas do mundo, o Brasil não merecia regressar aos tempos em que o voto valia menos que uma bala, por isso insisti numa transição segundo as regras do jogo democrático. Nesse sentido, designei uma comissão de transição sob a coordenação do Ministro da Justiça ( Célio Borja ), a mais antiga de todas as pastas. Alguns assessores e amigos,

310 revoltados com aquela conspiração, consideravam que o meu gesto apenas facilitaria o trabalho dos traidores, que loteavam o futuro governo e compravam votos com os recursos públicos, para vencer a batalha. Fiz-lhes ver que compartilhava aquele sentimento, mas o meu gesto era de zelo pela administração do país:

- 0 Brasil não é uma republiqueta. Quer uma transição decente.

A minha certeza era a de que o povo brasileiro compreenderia mais tarde que o meu governo caiu, porque não transigi nem permiti a negociação de votos no Congresso. Jamais tive qualquer sombra de dúvida do quanto contrariava as elites com atos de governo, e foram elas - e não o povo - os responsáveis maiores pela

320 pantomima, cuja cena derradeira se desenrolava diante das câmeras de todo o mundo, naquela manhã de outubro.

Notei, curioso, o primeiro secretário do Senado Federal um tanto trêmulo. Parecia muito compenetrado no papel a que se prestava. 0 governo seguinte o gratificaria regiamente, aliás, como à maior parte dos senadores que me julgariam, com

325 suspeita pressa e evidente falta de isenção, dali a exatos 89 dias ( a renúncia e o julgamento ocorreram a 29 de dezembro de 1992), embora o prazo fixado pela Constituição fosse de 180 dias.

0 vice-presidente (Itamar Franco), que retirei do ostracismo na política mineira, organizou um governo a que chamou cinicamente de " republica dos senadores" -

330 recompensando com cargos e sinecuras exatamente aquele que me julgariam mais tarde.

Causou-me especial emoção a solidariedade que recebi do deputado Ulysses Guimarães, naquele período duro de expectativa. Dr. Ulysses me visitou e me privilegiou com conselhos muito utéis, para enfrentar os dissabores que já não eram poucos e que se agravariam dali em diante. Todo o tempo assegurou-me o seu apoio - e o daqueles que o seguiram - afirmando que votaria contra o impeachment. 
Como demonstração de seu afeto, presenteou-me com um dos seus livros, no qual apôs solidária dedicatória. 0 seu comportamento mudaria quando se iniciaram as articulações para garantir a tomada do poder, através de um golpe de mão. Prometeram-lhe que o vice-presidente renunciaria logo após a minha condenação pelo Senado e, assim, ocorrendo a vacância do cargo, ele,Dr. Ulysses, finalmente cumpriria o sonho de exercer a Presidência da República eleito pelo Congresso, para cumprir o restante do meu mandato. Seu trágico desaparecimento jogou uma pá-de-cal na operação.

A sentença fora acertada fisiologicamente, enquanto a minha defesa era baseada em fatos concretos, argumentos jurídicos, provas que prevaleceriam no histórico julgamento do Supremo Tribunal Federal - que me absolveria em 1994, dois anos depois do impeachment. A decisão do Senado, "política", não poderia ser outra.

350 Percebi isso quando já era demasiado tarde. Renunciei ao mandato, como última tentativa de impedir aquele grotesco espetáculo, mas ainda assim realizaram o "julgamento". 0 objetivo era consumar o golpe e afastar-me da vida pública como uma maneira de protegerem os seus escusos interesses, finalmente vitoriosos.

Suspenderam os meus direitos politicos por oito anos, exatamente como a ditadura militar procedia com aqueles cuja ação política temia. 0 governo que me substituiu e seus cúmplices mal escondiam o temor pelo meu retorno, que sabiam inevitável, e por isso - ilegalmente - "julgaram-me". Não poderiam fazê-lo, porque apresentei a renúncia antes de a sessão ser iniciada. A Constituição autoriza o Senado a proceder o julgamento de Presidente da República e, com a renúncia, eu já não ocupava o cargo e o substituto já estava empossado. Adotou-se um rito previsto na lei 1079, de 1950, que regulamentava artigo da Constituição de 1946 e que evidentemente ja não vigoravam.

\section{Cabeça erguida e peito aberto}

Os bigodes de sopa do trêmulo senador ( Dirceu Carneiro), que Ihe cobriam inteiramente a boca, mexeram de forma engraçada, evidenciando que balbuciava. Muito tenso, ele falou baixo, tão baixo que ninguém entendeu nada. A cerca de um metro de distância confesso que me esforçei um pouco, mas só consegui perceber os bigodes movimentados nervosamente. Considerei apropriado, nas circunstâncias, responder qualquer coisa.

-Certamente que sim - disse em tom educado.

No dia seguinte, os jornais atribuíram ao senador uma frase de efeito, que, a rigor, se a pronunciou não se fez entender. "Desejo que este ato seja uma contribuição da nossa geração para o aperfeiçoamento da democracia no Brasil", teria dito. Olhei para o relógio, certificando-me da hora exata. Sobre o documento que recebi do

375 Senado, acrescentei a hora, a data e assinei: "Eu, Fernando Affonso Collor de Mello, recebi, nesta data, às $10 \mathrm{~h} 20 \mathrm{~m}$, a citação assinada pelo Presidente do Supremo Tribunal Federal e pela Mesa do Senado Federal, instruída com documentos de fls. 1 a 927, que me foi apresentada pelo Senador Dirceu Carneiro, na qualidade de primeiro secretário, para responder pela prática de crimes de responsabilidade, conforme acusação admitida pela Câmara dos Deputados, anexa. Palácio do Planalto, 2/10/92". 
Concluída a solenidade, pretendia deixar a sede do governo o quanto antes.

Despedi-me de todos os presentes, um a um, num clima de grande emoção. Fomos levados ao andar térreo, na saída reservada às autoridades, de onde seguiríamos ao heliponto. Atendendo minha determinação, a polícia não reprimiu os manifestantes que invadiram a área lateral do saguão do Palácio e ficaram a poucos metros de nós. Deixamos o Palácio com as cabeças erguidas, caminhando normalmente.

Com a omissão - quase a discreta ajuda - do serviço de segurança, os vociferantes militantes ficaram próximos. Pude vê-los de muito perto. Carregavam a mesma expressão, rostos crispados de ódio sem razão e da ira dos "valentões" de tantas outras batalhas. Imaginavam que eu os temia. Durante o percurso, encarei-os fixamente. Se os de Niterói desmancharam o cordão e se acovardaram por trás de pedras e insultos, os de Brasília emudeciam quando se surpreendiam com o meu olhar direto, sem temor.

Em meio àquela multidão havia também os que me aplaudiam, como um cidadão humilde que me fitava emocionado. Interrompi a caminhada, fui até ele, cumprimentei-o com um forte aperto de mão, agradeci a sua coragem. Naquele precioso instante, só por um instante, fez-se silêncio. Próximos ao helicóptero encontramos os integrantes do Gabinete Militar da Presidência da República em serviço - sempre corretos e eficientes - em formação, prestando continência. Aquela demonstração de lealdade me emocionou especialmente.

Eu e Rosane ainda nos voltamos para um derradeiro aceno àqueles que estiveram conosco até o último momento. Lembro bem que esse grupo ( formado pelos senadores Áureo Mello, Ney Maranhão, Odacir Soares, os deputados Humberto Souto, Ivan Buriti, José Burnett, José Lourenço e Paulo Octávio; Álvaro Mendonça, Lafaiete Coutinho, Luiz Carlos Chavez e Luiz Estevão) levantou os braços, formando a letra $\mathrm{V}$ com os dedos, gesto que repeti tantas vezes. Como eu, eles ainda acreditavam no retorno depois de estabelecida a verdade. Já a bordo, observando a manifestação do alto, não sentia raiva ou frustração, mas sim um profundo desapontamento. Pedi para sobrevoar os Ciac em construção em Santa Maria e Samambaia, cidades satélites de gente boa e simples, próximas a Brasília, e o do Paranoá, onde inaugurei o programa de escola em tempo integral. Seria um vôo de menos de dez minutos.

415 O comandante recusou:

- Não temos combustível.

Percebi ali que o poder escapara mesmo de minhas mãos. 


\begin{abstract}
ANEXO D
Reprodução da transcrição da entrevista televisiva concedida em agosto de 1998 ao Programa Livre, transmitido ao vivo pelo Sistema Brasileiro de Televisão (SBT), com duração de uma hora, dividido em 2 blocos separados por intervalo comercial, em que o ex-presidente é entrevistado por jovens estudantes mediados pelo apresentador Sérgio Groisman. Os locutores são identificados, na transcrição, como L enumerados de acordo com a ordem de apresentação do programa. Assim, para identificar os locutores, foram nomeados como locutor 1 (L1) os enunciados do mediador Sérgio Groisman e como locutor 2 (L2) os enunciados de Fernando Collor. Ao todo, são dezessete os jovens entrevistadores identificados como locutores L3, L4, L5, L6, L7, L8, L9, L10, L11, L12, L13, L14, L15, L16 e L17.

A referida transcrição, cuja reprodução gráfica é a original, foi retirada, com a autorização da autora, da dissertação de Mestrado pela FFLCH-USP de Bruna Wysocki, Interação face a face: um estudo das estratégias discursivas na reconstrução da imagem, de 2007, que foi acessada em 27 de fevereiro de 2010 por meio do link:

http://www.teses.usp.br/teses/disponiveis/8/8142/tde-05052008-153601/
\end{abstract}


L1 MAIS SOM ... ((aplausos)) mais mais mais mais mais mais mais... ((aplausos)) e boa tarde garoto boa tarde garota agora mais UM::.... PROGRAMA LIVRE... Programa Livre hoje especialíssimo... vai receber o ex-presidente Fernando Collor de Melo ao VIVO... com a gente aqui... colégios Equipe... Bandeirantes... Logus... Arquidiocesano... pessoal de Americana... Argos de Santo André... Anglo Vestibulares...portanto...no próximo bloco... ao vivo...o presidente expresidente Fernando Collor de:: Melo... Programa Livre dá um tempo e volta JÁ

10 L1 muito bem... voltando ao vivo aqui...SBT... Programa Livre...o expresidente Fernando Collor de Melo já está se dirigindo aqui... para os nossos estúdios... onde... em três minutos... sentará aqui... ((aponta para o assento destinado ao entrevistado)) pra conversar com a gente aqui... a respeito das perguntas que serão feitas pelos adolescentes...representando...a juventude brasileira aqui...hoje...no Programa Livre...pra gente ganhar tempo e ter 2 blocos bem grandes... sem intervalo... a gente vai pra mais um... em::: três minutos... a gente voltaVOLTA 


\section{BLOCO 1}

L1 muito bem...voltando ao vivo aqui pelo SBT Programa Livre... que recebe agora... o ex-presidente Fernando Collor de Melo ((entrada de Collor e vaias do auditório)) boa tarde... muito obrigado pela vinda... ao:: Programa Livre

L2 eu é que agradeço o convite que você me fez e é com muita alegria que estou aqui em seu programa

25 L1 muito obrigado e a partir de agora... vamos começar as perguntas... ao ex-presidente Fernando Collor de Melo... que está no Brasil efetivamente há quanto tempo? sei que tem uma ponte aérea aí mas...éh éh essa última vez tá quanto tempo aqui direto?

L2: não...já estou de volta ao Brasil des::de... fevereiro/final de fevereiro começo de março...

L1 agora vai ficar?

L2 e vou ficar aqui já estou de volta ao Brasil

L1: ta ok vamos começar as perguntas ah:: primeira garoto fala

L3: Rodrigo do Colégio Arbes... o senhor acredita que foi julgado e condenado por que estava num partido de menor poder político? assim... se o Sr. estivesse num PMDB ou num PFL se não... não seria condenado... no impeachment?

L2: não sem dúvida se eu tivesse maioria no Congresso Nacional... jamais... teria acontecido o chamado impeachment... e isso não foi dito por mim quer dizer isso foi dito pelos líderes inclusive da oposição... ah::: no fundo o que nós percebemos é que na eleição de $1989 .$. ela foi uma eleição solteira... ou seja foi eleito apenas o Presidente da República não houve eleição para deputado e para senador... de modo que quando eu tomei posse em março de $90 \ldots$ o Congresso... com o qual eu comecei a governar era o Congresso eleito em 1986... portanto... eleito esse Congresso num moMENto diferente da minha eleição seis meses depois da minha posse... houve a renovação desse congresso... que também foi eleito num moMENto diferente... daquele que elegeu o presidente em 89 essa eleição de 98 é uma eleição diferente porque é uma eleição casada... ou seja... quando a gente vai votar no presidente que a gente quiser... a gente é levado a votar... nos candidatos a deputados e senador... que estejam identificados com esse presidente... e isso constitui-se então a chamada base parlamentar... eu não tinha base parlamentar... o meu partido era pequeno... e continua sendo pequeno... se eu tivesse maioria no congresso nacional... nada disso teria acontecido.

L1: ok quem mais? ...tá com o microfone aí? não... então pergunte depois ce passa pra ele

L4: é::... diante de uma possível candidatura nessas eleições... como o senhor pretende i/éh:: se apresentar diante do povo que uma vez te elegeu e depois te depôs... e quais são as suas propostas?

L2: veja que... eu me apresento hoje diante...diante de todos vocês... tendo sido... o homem público... mais investigado desse país... o mais 


\section{BLOCO 1}

humilhado o mais xingado o mais achincalhado o mais execrado... $\mathrm{e}$ seguramente o mais investigado... o último homem público que sofreu alguma 65 coisa parecida... em termos de:: de::... investigação... foi o doutor Getúlio Vargas... em $1950 \ldots$ e que lamentavelmente não suporTOU... aquela pressão e deu fim a sua própria vida... então hoje eu me apresento... tendo sido... como disse... investigado de cima a baixo... quer dizer foram 2 anos de/e meio de investigação... em que investigaram... TOda a minha vida... e todo o resultado dessa investigação

70 foi levado a consideração da mais alta corte de justiça do país... que me considerou inocente daquelas acusações... e eu me pergunto se hoje... há um homem... bom se nós se nós estamos vivendo num estado democrático de direito... e se nós acreditamos... que à justiça cabe julgar as denúncias que são feitas... e não ao... ao nosso interesse partidário... então nós temos que reconhecer que

75 esse é o canal legítimo... que nós podemos recorrer dentro de uma democracia... para sabermos quem está com a razão... e a mais alta corte de justiça do país... me declarou inoCENte dessas acusações eu não sei se houve um homem público brasileiro... hoje... submetido às mesmas investigações a que eu fui submetido... se eles poderiam apresentar ao final dessas investigações... esse atestado... que me

80 foi dado pela mais alta corte de jusTIça do país... de inoCENte daquelas acusações... fui julgado pelos políticos... fui e fui condenado... fui julgado pela justiça e fui absolvido... e o que eu desejo agora... é nada mais nada menos... que seja dado o diREIto ao eleitor de fazer esse julgamento... sem intermediários... que votem contra mim ou a favor de mim... mas o eleitor... representando a sua

85 consciência representando o seu desejo representando as suas expectativas... e não que... meia dúzia de gatos pingados... lá no Congresso Nacional... se arvorem no direito de em nome de 35 milhões de eleitores... de fazerem o que fizeram... vocês todos se lembram que quem comandou... esse processo contra mim... foi o então presidente da câmara dos deputados... chamado Ibsen Pinheiro... que três ou 90 quatro meses após aH é:: eles terem me arrancado da presidência... eles mostraram a sua verdadeira face... Eles... os anões do orçamento... eles sim... estavam assaltando o tesouro nacional... eles sim... estavam fazendo as ...é as diabruras e travessuras que todos nós conhecemos... e se eles me arrancaram da presidência... é porque minha gente... seguramente eu não era um deles... e não 95 estava fazendo o jogo deles

L1: $\quad$ agora....é ...quando quando ((aplausos)) quando o senhor fala ((pausa prolongada)) quando o senhor fala quatro ou cinco gatos pingados... o senhor tá se referindo a maioria do Congresso naquele momento... TAMBÉM eleito pelo povo assim como o senhor

100

L2: $\quad$ sem dúvida sem dúvida/me refiro/quer dizer é uma força de expressão... eu me refiro ah:: ao Congresso Nacional comandado... por este que eu já falei o nome... e que em nome de 35 milhões... né?... tomaram aquela atitude sem terem autoridade moral para isso porque ele que comandou tudo ele que atropelou todo o processo... porque minha gente vocês talvez não tenham... parado um pouco pra acompanhar todo esse processo foi uma... foi uma... do ponto de vista jurídico né?... foi uma violência atrás de outra porque não me foi dado direito de defesa em nenhum instante não me foi dado ah: oportunidade de poder falar... dentro ((risada)) dentro do processo... de modo que as coisas foram acontecendo assim de uma forma ah:... violenta... e ah: ah ah inclusive... 


\section{BLOCO 1}

afetando a própria constituição né?... de modo que:: o que eu desejo nesse momento é de colocar o meu nome ao julgamento popular é só isso

L1: quem? quem? quem? quem? quem? quem?

L(?) (incompreensível)

L5: é::: o senhor acredita no dito popular que o brasileiro não tem memória... por isso o senhor está ree/candidatando... a propósito o senhor tem memória? ((gritos e aplausos))

L2: $\quad$ não o povo o povo o povo brasileiro o povo brasileiro tem memória $o$ povo brasileiro tem memória... o que... o que o povo brasileiro está fazendo né? deste período para cá... é fazendo o seu verdadeiro juízo... porque eu digo pra vocês minha gente eu já tive a idade de vocês... não é eu já estive em colégios secundários eu era líder estudantil era líder é::... na universidade... na época do golpe militar né? eu levei muita pancada... fui preso duas vezes... de modo que eu se tivesse na posição de vocês naquela oportunidade com aquela campanha da mídia eu seguradamente estaria também na ruas pedindo a deposição do presidente que fosse... então eu eu entendo perfeitamente tudo que se passou e entendo... a mobilização que foi feita com os jovens porque eu também já fui mobilizado... então ah: de modo que eu acredito que o povo brasileiro sim tenha memória... eu tenho memória por exemplo memória... exata de tudo o que aconteceu... desde que eu comecei di a::: na::: minha faixa dos quatorze quinze dezesseis anos... a participar de alguma forma da vida política do meu país... e eu tenho a memória muito grande de tudo o que aconteceu... agora acontece que ao longo do tempo a gente vai fazendo o nosso juízo... porque muitas coisas que dizem... quantas vezes a gente não /uma pessoa não chega pra gente e diz assim... é ó não fala com esse camarada não porque ele não presta porque ele é um chato... e daqui a pouco a gente vai falar com a pessoa e descobre que é completamente diferente daquilo que nos disseram... o que é importante o que é importante é que seja dado oportunidade... ao povo brasileiro de fazer o seu juízo dentro de um ambiente de razoável tranqüilidade... sem que haja um clima de emoção... transbordando pelas ruas... de modo a dizer... esse fulano aqui é é culpado... temos que crucificá-lo ele é o causador de tudo e tal... nós temos que ter uma ponto de razão... e pra isso é preciso que tenhamos memória... e o povo brasileiro TEM memória

150 L1: ok...em cima garoto... garoto fala

L6: é...eu queria saber ...depois de... depois de tudo que o senhor foi acusado... o que você acha da miséria assim que está no Brasil... na:: em questão à seca... do nordeste assim... e o que o senhor acha do plano do Fernando Henrique?

155 L2: bom nós tamos viven::do... um momento... de extrema gravidade no país não é... todos nós sentimos nas nossas casa vocês sentem nas suas as dificuldades por que passa o país... nós temos hoje alguma coisa que a sociedade conquistou que é positiva... que é chamada a estabilidade monetária... mas acontece que essa estabilidade monetária... está 160 sen::do... mantida a custa de um enorme sacrifício... nós temos hoje desemprego recorde no país... a saúde nunca esteve numa situação de calamidade como hoje se encontra... e nós nos lembramos que nos foi 


\section{BLOCO 1}

pedido o imposto do cheque... o chamado CPMF dizendo me dêem o CPMF que eu salvarei a saúde... o CPMF recolhe de seis a sete bilhões por ano... e desses recursos quase NAda vai para a saúde vocês aí alguns alguns são universitário né?... e sabem que hoje a universidade está relegada... a um plano secundário... quando a universidade num num mundo globalizado como está... tem que se a fonte de cérebros e de mãode-obra extremamente qualificada... para ajudar o país a competir nesse mundo globalizado... nós temos aí os aposentados sendo tratados com adjetivos e:: de forma pejorativa... nós temos aí o/ah:: os funcionários públicos que estão há quatro anos sem reajuste... nós temos aí os comerciantes... os empresários os industriais que estão quebrando estão falindo... por culpa desses juros extorsivamente altos que estão impedindo o país de progredir... enfim... e nós vemos aí esses efeitos todos causados pe/pe/pela po:lítica econômica e ficamos todos muito preocupados a crise que se abate sobre o país é séria o organismo econômico brasileiro está debilitado... e... portanto qualquer vírus que venha lá de fora seja da Ásia se/seja da Rússia vai pegara esse organismo debilitado... e pode sub/submeter a esse organismo a um processo duríssimo... de uma doença de difícil recuperação... por isso é que eu acredito que é necessário nós fazermos mudanças profundas... mantendo a estabilidade mas com desenvolvimento

L1: agora...é...na hipótese... do senhor (poder) se candidatar poder se candidatar através do TSE e numa hipótese... de um segundo turno ah::é::exsistir o que existe hoje uma::... uma::... uma briga bem forte entre Lula e Fernando Henrique... no segundo turno... em quem o senhor votaria?

L2: $\quad$ eu votaria no Lula

190 L1: no Lula... por que... por que essa mudança tão grande?

L2: $\quad$ porque... o Lula e outro dia num programa de rádio... outro dia num programa de rádio... outro dia emBOra eu ache que num segundo turno estaremos novamente eu e Lula... mas num ((gritos da platéia)) num programa ((gritos da platéia)) me permitam dizer isso ((gritos da platéia)) bom ((silêncio)) mas deixa eu dizer... deixa/deixa eu dizer... então eu estava num...num programa... num programa de rádio num debate... e me perguntaram alguma coisa sobre o::... eleição e sobre:: o Lula ...e tal e eu me referi ao Lula como o companheiro Lula... e havia dentre os jornalistas dois que eram do PT... e eles intrigados com aquilo de 200 companheiro companheiro aí ele me pergunta... mas pera aí... como chamá-lo de companheiro... ele não é seu companheiro... aí eu disse engano seu... nós fomos companheiros no:: na campanha das diretas... nós fomos companheiros na disputa pela presidência em $89 \ldots$ e hoje somos companheiros na mesma visão crítica que TEmos... do governo FHC... então não posso /posso dei/ é:: é:: deixar de dizer que eu me considero HOje... e nessas circunstâncias um companheiro... e falo...e falo que num segundo turno embora eu acredite... segura $\mathrm{e}$ sinceramente... que num segundo turno estaremos Lula e eu novamente reedidanto... a final de $89 . .$. se houver... se houver se...não der isso... e se der Fernando Henrique e Lula... eu votarei em Lula para presidente

L1: $\quad$ aqui ah 


\section{BLOCO 1}

L7: é:: o senhor acha que o que aconteceu com PC Farias foi queima de arquivo?

L2: não sei se foi queima de arquivo ou se... o que houve exatamente... eu devo me valer... do relatório da polícia... que foi muito investigado né? vários investigadores substituíram vários investigadores até chegarem a conclusão... de que foi um clima um crime passional né? ...então eu tenho que me valer pelo laudo que a polícia divulgou e tornou oficial.

L8: alô... senhor presidente eu queria saber ah... porque o senhor se declara totalmente inocente né? e... que foi na verdade posto num esquema

L2: não ninguém ninguém é santo... eu não sou santo eu cometi erros

L8:

o senhor expôs mas da maneira

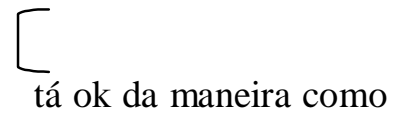<smiles>[CH]CC[CH2-]</smiles>

L2: $\quad$ claro... claro que eu cometi erros agora... não só um minutinho... agora... agora... agora nenhum nenhum... nenhuma dessas... acusações graves que me fizeram elas foram verdadeiras... porque se fossem verdadeiras eles teriam vocês não acham que eles teriam me condenado claro que teriam... na/nada disso tanto que não foi porque foram dois anos e e meio de investigações ta certo... desculpe a interrupção

230 L8: com certeza o senhor fala que... foi investigado sua inva/éh:: sua privacidade foi invadida e tal... só que a maioria dos brasileiros não...o consideram inocente eu queria saber como o senhor lidá com isso de... legalmente sendo inocente mas... é... moralmente eu acho que não é por aí ...entendeu ((aplausos e gritos))

235 L2: veja...((gritos do auditório)) veja... ((gritos do auditório)) veja... ((gritos do auditório)) é pra isso é pra isso que existe uma eleição... entende é pra isso que existe uma eleição ah:: e é pra isso que eu desejo ouvir... a resposta popular nas urnas... quer dizer você fala e com toda... e com toda a propriedade que o :: que o seu entendimento... ah:: merece... de que esse não é seu entendimento... mas vamos vamos ouvir... o conjunto da população... e é exatamente essa resposta que eu estou buscando... eu estou buscando... nas URNAS a resposta da população brasileira... a essa dúvida que alguns segmentos ainda têm... e eu desejo democraticamente submetendo o meu nome a julgamento popular... ter esse julgamento popular... nas eleições de 98

L9: $\quad$ senhor senhor ex-presidente eu queria saber do senhor... sem muita auto propaganda... se:: o senhor dorme tranqüilo sabendo mesmo sabendo que:: cento e cinqüenta milhões de pessoas te odeiam? ((gritos e aplausos da platéia))

250 L2: não não exagera ((gritos da platéia)) ((risadas)) não exagera não exagera cento e cinquienta milhões não até porque... no/ nós temos que... ((barulho e risada de L2)) veja bem... não é... e é por isso é ser isso que eu desejo... eu:: eu repito né? é por isso que eu desejo submeter o meu nome a julgamento popular porque eu desejo saber... realmente... qual é 


\section{BLOCO 1}

o julgamento popular... sobre o meu período como Presidente da República e sobre as expectativas que eu posso despertar ainda no seio da população em relação ao nosso futuro... é essa a resposta que eu busco

L1: $\quad$ cadê....aqui aqui aqui

L10: gostaria de saber a sua opinião... sobre a grave cri::se:: social que o país está enfrentando no governo Fernando Henrique... inclusive o desemprego que é assustador um milhão e seiscentos mil de desempregados só na grande São Paulo?

L2: éh o desemprego o desemprego o desemprego minha gente realmente é... é... enorme... é gritante nunca um país ah é::ah:: encarou enfrentou um problema social como este... e na / no o desemprego é causado... basicamente por uma política econômica que está em curso... há um desemprego inicial... nesse mundo chamado globalizado... que é causado pela globalização... os países ricos e desenvolvidos por exemplo... ele tem desempregados... e quem são esses desempregados? os desempregados dos países ricos e desenvolvidos são aqueles trabalhadores que... extremamente qualificados... recebem um salário... compatível com essa qualificação... por exemplo... um programador de software na Alemanha que ganhava dez mil dólares por mês... foi... está sendo despedido no início do processo de globalização... substituído o seu trabalho por alguém que na índia Bangladesh por exemplo faz aquele mesmo tipo de serviço por mil dólares... então o desemprego no início do processo da globalização... num mundo desenvolvido e rico... afetou mão-de-obra extremamente qualificada... e com remuneração compatível com essa qualificação da sua mão-de-obra... nos países chamados emergentes nas economias emergentes como o Brasil... o desemprego pegou inicialmente quem?... exatamente o trabalhador com sinal oposto... o trabalhador desqualificado que nem...nem com um processo de reciclagem conseguiu estar apto para enfrentar essa competitividade no/no mercado... e que recebia um baixo salário... então vocês vejam que lá os órfãos os órgãos da chamada globalização... lá no mundo desenvolvido são funcionários qualificados no mundo em desenvolvimento são funcionários... sub-qualificados então esse é um desemprego que a gente entendo que tem sido causado pela globalização o excesso de desemprego... quer dizer esse/essa margem é ah...ah enorme a mais de desemprego no Brasil... vem sendo causada pela política econômica... pela política monetária e política cambial o que significa isso taxa de juros extremamente elevada... e uma moeda supervalorizada que retira... lá... dos nossos produtos... da competição externa pela supervalorização ou sobrevalorização... do chamado real... então o que nós precisamos é de aprofundar as reformas andar com as reformas por exemplo tributária fiscal para evitar que essas duas âncoras ah:: a monetária e a cambial proporcionem isso que nós estamos assistindo hoje... que não é somente o desemprego... mas é uma crise social sem precedentes aqui em São Paulo a cada vez que volto a São Paulo... eu encontro mais relatos e mais pessoas é dizendo sobre a insegurança que vivem aqui na capital... dos assaltos que são feito enfim desse/desse clima quase de estado de sítio em que:: está vivendo as grandes metrópoles das quais São Paulo sem dúvida é a mais importante

L11: oi eu queria saber como você responde hoje as acusações que foram feitas sobre o uso de drogas 


\section{BLOCO 1}

L2: $\quad$ sobre o uso de drogas? ((aplausos e gritos do auditório)) olha ((risada)) isso aí ((risada)) isso aí já...já foi tão...tão dito e tão... e tão repetido não é? eu quero dizer a vocês que... eu quero dizer a vocês que... ah:: todas essas acusações... também são acusações falsas... vocês sabem... vocês sabem... vocês sabem... conhecem a minha vida... não é... conhecem a minha vida que foi muito bem é:: explorada pela imprensa e muito bem dita... eu sempre fui uma pessoa dedicada a uma vida exTREmamente saudável... sempre fui... sempre fui... desportista... não é?... sempre pratiquei os meus esportes a vida ao ar livre e... nas vezes que eu posso falar com pessoas como vocês eu sei que vocês gostam também muito de esportes eu digo olha minha gente... vão pro esporte vão pra fazer uma atividade física deixa essa coisa de droga de lado porque não leva... ninguém a nenhum lado... então eu quero é exaltar é exaltar a saúde... a condição e o condicionamento físico... como uma maneira que nós temos de administrar BEM... aquilo que Deus nos deu que foi o nosso corpo... se nós não administrarmos BEM... o nosso corpo cuidando da nossa saúde... nós não saber/ saberemos administrar nada na nossa vida.

L12: é:: eu quero saber se::::assim/se:: quer se submeter a um julgamento popular agora né?... então eu quero saber se você não acha... que:: o seu poder de persuasão é maior que a capacidade de discernimento do povo... que não tem cultura... e não tem e...ducação necessária pra/e é facilmente manipulado? ((gritos e aplausos do auditório))

L2: veja que:: ((gritos do auditório)) você me atribui um poder de persuasão que eu não sei se tenho... o que eu sei que tenho

$330 \mathrm{~L}(?):$

L2:

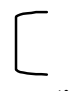

$$
\text { (incompreensível) }
$$<smiles>C1CCCC1</smiles>

bom então se tenho

obrigado ((risada do locutor e aplausos do auditório)) agora... agora... agora pessoal... o que eu sei que tenho é o seguinte... é o que muitos de vocês têm... eu não sei fazer nada na minha vida que não seja com paixão... com ardor e ((risos e gritos do auditório)) com vontade ((risos e gritos do auditório)) não não a paixão piegas ((risos)) não... não... cês estão entendendo... não é essa paixão não é essa paixão piegas paixão piegas é uma paixão no sentido de me dedicar inTEgralmente àquilo que eu tô fazendo... então... então... às vezes... às vezes... vocês é como ela entende a persuasão... ah:: talvez seja a vontade que eu tenho de transmitir a Minha verdade cada um tem a sua verdade... e eu GOSto de transmitir a minha verdade com a absoluta sinceridade... e com e com absoluta convicção daquilo que estou dizendo... e não sou somente eu... eu acredito que todos aqueles que... estejam numa posição de:: homem público... colocando seu nome ao julgamento popular... eles têm não somente o direito mas o deVER de passar a sua verdade... e deixe que população... o povo eu sempre digo... o povo pode ser inculto... mas não é burro... o povo é muito mais sábio do que nós podemos imaginar... e o povo é o que nós temos sempre que ver minha gente... as grandes transformações sociais... as grandes transformações sociais as grandes mudanças históricas ocorridas no mundo em qualquer época que se considere... teve a decisiva participação popular... então o povo

L(?): (incompreensível) 


\section{BLOCO 1}

L2:

bom mas se você disser que foi manipulada você também pode ah:::ah::dizer que ah::ah:: aqueles que saíram às ruas de cara pintada contra mim foram manipulados e::

$\mathrm{L}(?)$ :

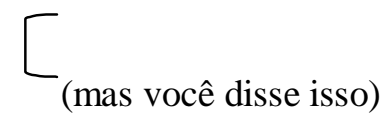

L2: eu não acredito que dizer ((gritos do auditório)) não ((gritos do auditório)) a manipulação... minha gente a manipulação ela a manipulação ela pode existir existir mas em determinado momento em relação a um a um determinado segmento... a manipulação não é geral... é impossível haver uma ma-ni-pu-la-ção global minha gente

L1: ok no próximo bloco a gente continua... programa livre dá um tempo volTA JÁ 


\section{BLOCO 2}

365 L1: beLEza voltando ao vivo... aqui... no SBT Programa Livre com o expresidente Fernando Collor de Melo... garoto fala

L13: já que tava falando de manipulação... eu queria saber se... você não acha que se não tivesse sido tão ajudado pela Rede Globo... principalmente no seu último debate com o Lula que foi editado para ser passado no Jornal Nacional se o senhor teria ganhado as eleições? ((gritos e aplausos do auditório))

L2: olhe... é preciso a gente... voltar um pouco atrás não é e:: para ver como foi:: como se realizou a eleição em $1989 .$. em $1989 . .$. eu era... um candidato... considerado azarão... por quê? porque eram as primeiras eleições democráticas depois de quase trinta anos de jejum de abstinência eleitoral não é... depois do golpe de 64 nós ficamos quase trinta anos sem eleição para presidente... e então em $89 . .$. qual era ah:: o que se discutia né?... com tantos nomes... pesos pesados da política nacional... havia aí já falamos do do Lula... do Ulisses Guimarães o Mario Covas o Paulo Maluf o Guilherme Hadib Domingues o... Leonel Brizola enfim... e havia um um candidato a presidente... que::: tinha saído do governo de Alagoas com um partido inexpressivo... do ponto de vista do:: de conhecimento:: da população e de capilaridade ou seja de representação dos municípios brasileiros... então naturalmente não é nem porque a imprensa não quisesse... é a:: à minha candidatura não há não era dada nenhuma importância porque achavam que era uma brincadeira... então no primeiro turno da eleição o que nós assistimos... foi exatamente isso... a grande mídia dando um cobertura ah::: aos::: candidatos... e naturalmente àqueles que eram conhecidos até porque eu acho que a população queria saber mais... dos candidatos que elas que ela população conhecia melhor não é?... no segundo turno foi diferente... porque no segundo turno como vocês sabem... é plebiscito... é::: azul e vermelho é branco e preto não é? não tem não tem meio termo o segundo turno turno é::: foge inteiramente à racionalidade da eleição...muita gente chegou e disse assim não eu votei eu votei no Collor porque:::eu não queria o Lula... não eu votei... no Collor porque::: eu achei que:: o Lula ia fazer alguma coisa de comunismo no país... essas coisas bobas... não é:.: esses raciocínios bobos não é::: mas que naturalmente não significam que se votou naquele candidato escolhido porque gostaria de votar nele... então ah::ah:: no segundo turno.. ah o que houve foi um posicionamento... dos diversos órgãos de comunicação em relação a uma candidatura ou a outra eu não eu-não concordo na questão da manipulação o que dizem que a Rede Globo fez em relação ao debate porque o debate foi transmitido ao vivo para todo o Brasil... em cadeia nacional de rádio e televisão... então foi um dos programas... foi esse horário um dos mais ouvidos não é... um dos maiores ibopes havido naquele tempo foi exatamente o debate final... entre Lula... e eu na disputa pelo segundo turno... então é difícil haver manipulação quando a transmissão é ao vivo... que manipulação pode haver?... nenhuma manipulação eu acredito que o o::: o fundamentalmente o que::: o que houve... o que houve... o que houve do mesmo modo que no primeiro debate eu não fui bem... no segundo debate eu acho que fui melhor que o Lula... então o que ficou foi a impressão do último debate

L13: mas a edição que eu estou falando é::um resumo que foi feito pra ser passado no Jornal Nacional... eles fizeram um resumo de seis minutos... 


\section{BLOCO 2}

que passou::: praticamente :: um minuto a mais do senhor falando que o Collor/que o Lula

L2: $\quad$ bom isso aí eu não não imaginei não peguei não sei ((vais do auditório)) mas fundamentalmente o que houve foi isso quer dizer o debate passou 420 ao vivo... o debate passou ao vivo

L14: $\quad$ primeiro eu queria dizer que eu tenho esperança de que você não vá para o segundo turno... e depois eu queria saber que:: você gostando tanto da natureza por que o senhor não fez nada pelo meio ambiente e:::

L2:

pera aí não ((risos))

nossa senhora<smiles>CCC</smiles>

L14:: e não e que você pode fazer mesmo sem ser presidente da república você não precisa disso<smiles>CCC</smiles>

L2: $\quad$ sei mas pera aí pera aí pessoal assim também não ((risos e aplausos)) nossa senhora em relação a

(incompreensível)

L2: em relação a questão ambiental a questão ambiental o que o avanço que o Brasil deu na minha administração olha... não é não é não sou eu que tou dizendo... não sou eu minha gente que tou dizendo... isso aí são os próprios organismo internacionais não é::... no que diz respeito respeito à política indígena... no que diz respeito respeito à política indígena... à política ambiental o Brasil deu um passo giGANtesco nós realizamos aqui em 1992... a maior conferência que é/ah:: tomando-se em consideração para dizer se é a maior... o números de chefes de estado e chefes de governo presentes nessa reunião... foram $158 \ldots$ chefes de governo e chefes de estado e estivemos reunidos durante quinze dias... lá... no Rio de Janeiro tratando exatamente de avanços com propostas ambientais para salvar o nosso planeta... nós assinamos tratados da maior importância essa conferência do Rio sobre meio ambiente e desenvolvimento é considerado um marco... um marco histórico pela/na luta ambiental... na questão indígena... não sei se vocês se lembram... mas nós conseguimos salvar os ianomani... os iannomani estavam sendo dizimados pela ação... dos homens brancos... e por ação de uma poLÍtica indigienista que o/os levaria certamente à extinção... e nós fizemos uma reserva de oito:: milhões de hectares na Amazônia... exatamente para preservar uma das culturas mais antigas de que se tem notícia nas nossas Américas... ah:: na questão do... na questão da do nosso dia-a-dia eu fiz incluir no currículo escolar ah:: uma disciplina de educação ambiental para que desde a mais a/a a criança né? a mais tenra idade pudesse tomar conhecimento da importância que tem a nossa natureza... não enfim... eu acho que:: em relação à questão ambiental nós demos um passo MUIto grande e/eu quero até lembrar a vocês um episódio... ah:: eu gostava muito e continuo gostando hoje talvez um pouco menos mas eu gosto de velocidade eu gosto de esportes perigosos... e eu fazia... eu fazia jet ski... e uma vez o Jacques Costeau o Jacques Costeau é:: o comandante 


\section{BLOCO 2}

460

465

470

475

L1: fala fala garoto

L15: senhor presidente... eu queria::: bem/ você pelo jeito que tá... criticando o Fernan/Fernando Henrique você deve... querer algumas mudanças né?... e eu gostaria de saber como você pretende fazer isso... partindo de uma família oligárquica do nordeste... e com apoio de:: grandes interesses lá que:: é mais do que sabido... que eles mantém a miséria daquela população... para que elas não tenham educação... entendeu... e pra dar o voto... os chamados currais eleitoreiros né?... pra como... currais eleitorais... entendeu? que usam esse voto entendeu dessa população miserável que não tem educação... entende?... e aí pode... pode... de repente eu não sei se é o caso do senhor... mas é o que me parece apoiar um certo candidato e esse candidato acaba vencendo... eu quero saber... e qual é a bancada ruralista né?... que é uma bancada ruralista né? que:: vende votos né?... que é um absurdo... o Fernando Henrique tá tendo que ah::ah:: aprovar algumas coisas ta tendo que::... gastar não sei quanto em cada votação... eu quero saber VOCÊ entende? partindo dessa base eleitoral que é o nordeste... como é que você pensando em fazer algumas mudanças e:: com esses interesses... só pra complementar ((entrega o microfone a L16))

L16: ó... você falou aqui... que::.... ó... algumas é... incoerências aqui no seu discurso tá... você falou da equipe econômica do Fernando Henrique mas muitos membros da equipe econômica do Fernando Henrique foram... membros da sua e/equipe econômica como o Candir tá... o:: o... Renan Calheiros que é o ministro da:: da:: justiça que... cê acabou de citar como... que você... não foi é::: culpado pela justiça não sei o que foi é :: teu colega de Alagoas é ministro da:: da justiça lá... você também falou do congresso nacional... só que no segundo turno da eleição... é::: a grande maioria do congresso... foi a favor seu... principalmente o PFL ou na época o PDS né? toda a bancada deles eram a seu favor... e você tinha maioria do congresso no começo do governo... e outra coisa... você falou que... por falta talvez de memória nossa aqui... você era um considerado um azarão na campanha de $89 . .$. mas desde da convenção do PMDB por exemplo:: você já... já estava em primeiro lugar na... na eleição na pesquisa com que... pra/ explicar que a convenção do PMDB foi feita na mesma época que/que tamos hoje aqui pra eleição mais ou menos... você 


\section{BLOCO 2}

já era já era o primeiro lugar empatando com o Quércia né? na::: época na época daí elegeram o Ulisses Guimarães na convenção então você não era você não foi um azarão você falou que no no segundo turno as pessoas não votaram em você... porque::você tava ah:: é ...não:: ia:: é:: votar votavam em você porque não iam votar no Lula... só que desde o primeiro turno você já tinha quarenta porcento dos votos... tá e agora eu vou fazer uma pergunta pra você ((risos de Collor e aplausos do auditório)) ó tendo em vista a guerra civil colombiana que podemos presenciar neste momento ((gritos do auditório)) eu quero dizer que... a guerra civil foi provocada na:: Colômbia... porque em 1958 pela aliança do::: partido conservador e o partido liberal que são... o equivalente no Brasil aos partidos conservadores da elite... burguesa... que governam o nosso país... eles chegaram a um acordo... e:: começaram a governar o país... pó/por democracia democraticamente e:::: esse acordo fez surgir a sombra... a sombra desse governo... o as guerrilhas colombianas tipo FARCS e:: Exército de Libertação e etc e essas guerrilhas hoje comandam... é:: quarenta porcento do país junto com os grupos paramilitares lançados pelo... pela aristocracia rural e pelo governo norteamericano... aí eu que/queria fa/falar eu queria que você ((gritos do auditório)) respondesse pra mim... eu queria se você não tem medo que /com a elite contínua no governo Brasil democrática com essa falsa democracia que governa hoje... o:::: movimento sem terra se armar por exemplo... como se armaram os exércitos... de libertação da Colômbia se armarem... e provocar uma guerra civil no Brasil ((aplausos e gritos))

L2: eu continuo... eu continuo acreditando eu vou tentar... eu vou ver se me... me lembrarei lembrarei... das das perguntas que foram feitas ((gritos)) e se faltar alguma por favor vocês me lembrem bom vamos começar pela última aí que me parece... a mais... a mais importante... e ah::

L?:

L2:

L?:

L2: conjunturalmente mais ((pausa prolongada)) qual foi mesmo? ((gritos)) ah das oligarquias então vamos começar pela dele... ah:: a minha família... não é uma família que é:: a gente pode chamar de oligárquica

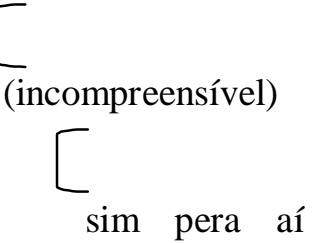

mas lá existem... veja bem... no/nós somos nós somos a nossa família... é uma família basicamente de jornalistas... era jornalista meu bisavô meu avô meu pai e nós nós<smiles>CCC</smiles>

(incompreensível)

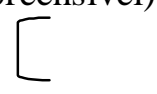

não não diga isso... não diga isso... isso é uma agressão desnecessária... bom e... e eu também entende... então também... então nós sempre nos dedicamos ao jornalismo sempre nos dedicamos ao jornalismo ah:: e temos lá empresas de comunicação... há muitos e muitos e muitos anos... e não temos... não somos proprietários rurais nunca criamos ou plantamos nada... nos dedicamos única $\mathrm{e}$ exclusivamente à família ao nosso negócio ao nosso ao nosso trabalho que é a de comunicação... com televisão com rádio com jornal e com gráfica e editora... bom... então é isso então não pertencemos à 


\section{BLOCO 2}

oligarquia... na questão de da candidatura minha ao governo do estado... foi uma candidatura... em que se rompeu pela primeira vez os chamados currais eleitorais... a campanha eleitoral em 1986 a o:: governo de Alagoas foi uma campanha de uma violência brutal... que a gente só vê talvez em filme e mesmo assim não acredita... por quê? porque eu me insurgi exatamente contra esses currais eleitorais... eram currais inexpugnáveis... daqueles coronéis né?... que dominavam aqueles votos... e que com a MINHA candidatura esses currais acabaram sendo colocados abaixo... ah foi uma... uma eleição... em que da minha coligação fazia parte o PC do B PC do B estava na coligação comigo para governador do estado... e eu conheço bem e alguns de vocês conhecem... eu admiro... o trabalho do PC do B e tenho lá pessoas com as quais eu me relaciono... e eles não iriam entrar em nenhum projeto... que fosse um defender oligarquias ou muito menos é:: a manutenção de currais eleitorais... de modo que :: e/ no no que diz respeito à campanha presidencial... é claro... eu não era conhecido... tanto que eu tinha manifestei a minha intenção de:: sair candidato... eu tinha um porcento eu alcancei... ah:: emparelhei com o Brizola e com o Lula... ah::: em::..... maio ((pausa prolongada)) maio... junho... de 89... foi aí que nós emparelhamos numa pesquisa do GALUP... a partir daí... houve um crescimento grande da candidatura... houve um crescimento grande... eu tive/cheguei a quarenta e cinco porcento das intenções de voto... e depois... caí... de julho... até:: outubro... quando foi a eleição... eu caí para vinte e quatro ou vinte e cinco porcento das intenções de voto no primeiro turno... eu tive vinte e um milhões de votos... o Lula teve onze milhões e o Brizola teve dez milhões e quinhentos os dois disputaram até o último momento qual deles... estariam no/no segundo turno bom... agora então em relação a sua e a questão conjuntural... a democracia ah::: uns dizem não porque democracia porque a democracia tá é::: falha a democracia está doente a democracia é isto ou aquilo... nós temos que entender para facilitar o raciocínio... vivemos numa democracia ou não?... então a primeira pergunta é a seguinte há eleições livres? há... os poderes funcionam independe e livremente o congresso nacional justiça e o executivo? funcionam... a imprensa é livre?... a imprensa é livre?... é... então esses são os três fatores que convencionamos utilizar para saber... rapidamente... se vivemos numa democracia ou não é claro que a democracia significa isso... é o embate de/ de idéias é a troca de opiniões... quer dizer é::: ninguém é:: partidário somente de uma coisa... todos nós temos as nossas opiniões e o importante é que nós possamos expressar a nossa opinião... e só podemos expressar a nossa opinião num regime democrático como hoje estamos fazendo aqui... o que acontece no campo... é:: o que verificamos é... uma absoluta falta de controle... do governo... em relação a esta situação... porque quando começa é::: irmãos ou brasileiros a trocarem tiros... no:: no campo... e em busca da terra ou pela posse da terra... nós começamos a verificar o seguinte vem cá e onde está o governo nisso tudo... por quê que o governo não intervém de uma forma nesse conflito e diz pera aí mi/é gente vamos parar com isso... venham pra cá vamos nos sentar... então senta o aqui o movimento dos sem terra senta o :: representante da bancada o... o dos ruralistas... sentase ministro da agricultura da reforma agrária ministro da justiça vem cá... o que que você quer... anota... o que que agente pode dar... anota... vamos chegar aqui então a um consenso isso a gente pode não pode e é assim que se faz... essa coisa de buscar na bala... e com vítimas... disputa pela terra isso é coisa da idade média... hoje em dia não se pode mais entender que numa numa num estágio da civilização em que nós esteja/ e 


\section{BLOCO 2}

615

620

625

630

635 L2:

L1:

L2:

L1: $\quad$ uma verdade né?

640 L2: é uma verdade agora veja um:: veja que paradoxo veja que paradoxo o o::: governo FHC... foi aquele que mais assentou... sem dúvidas... foi o que mais assentamentos fez... bom e se é o governo que mais assentamentos fez... por que... hoje estamos assistindo a essa enorme revolta dos sem terras? não há aí um paradoxo?... porque se é o governo que mais assentamentos fez... então se deveria dar a ele um certo crédito... e deveria o movimento estar de alguma forma satisfeito porque está vendo a proposta da reforma agrária avançar... e porque nunca o clima... no:: na região na zona rural o clima no interior nunca esteve... TÃO tão grave nunca esteve TÃO aceso nunca as paixões ficaram desen/ desencadeados de uma maneira TÃO forte... por quê? porque o programa de reforma agrária não está sendo feito da forma que deveria ser feito... não adianta a gente a gente chegar numa fazenda retaliar e dizer você então fica com este pedaço de terra você fica com este e você com aquele... o que... o que tem que se fazer é ao mesmo tempo em que se dá a terra tem que se dá a semente... tem que se dar o apoio técnico para plantar... tem que se ter uma política de preços mínimos para garantir... a remuneração do:: de que ele vai produzir... tem que haver as vias de escoamento para poder retirar a safra de onde está para os locais de outras e sem que o governo tome uma iniciativa para resolver essa situação... então ah ah:: situação do Brasil é é diferente da Colômbia Colômbia e de outros países nós não temos uma tradição é::de:: ah::: é:::: ou aquilo outro porque hoje... o combate se faz pelos partidos políticos e pela eleição que se processa regularmente a cada dois anos dois anos pra::: de dois em dois anos nós temos eleições porque intercaladas prefeito e vereador e depois governador e senador e presidente da oportunidade da população se manifestar livre e abertamente pelo voto a sua satisfação ou a sua insatisfação... é o caminho que nós temos naturalmente para resolver os nossos conflitos desde que tenhamos um governo... com pulso... um governo com iniciativa e com sensibilidade... campo... sobre pena de entrarmos num clima... de muito perigo que não interessa a nenhum de nós

comparativamente esse governo tem feito MUIto... em relação ao governo ::: que o senhor teve em relação à reforma agrária

famílias foram assentadas isso isso é ah ah

muito mais

que nós estamos... que nós assistamos pela televisão diariamente... essas 


\section{BLOCO 2}

distribuição... tem que haver também uma mínima infra-estrutura... para que ele possa manter o assentado possa manter a sua família... tem que ter um posto de saúde tem que ter uma escola porque senão o que ele vai fazer naquele meio de mundo... com a mulher com os filhos e ele sem/se tiver uma doença não tem onde levar se o filho... o filho quer estudar e não pode... então o que falta é exatamente isso é uma consciência... global... do problema da reforma agrária... e esse governo embora tenha feito/ foi o que mais distribui foi o que mais assentou... foi e::e:: não está dando resultado por quê? porque não está dando a infra-estrutura mínima necessária... para que esses assentamentos possam funcionar a contento

L17: durante as eleições em 89... você falou que o Lula ia confi/ confiscar as poupanças e quem acabou fazendo isso um dia depois de ser eleito foi você... cê acha que um:: candidato POde mentir para ser eleito ou omitir?

L2: veja que eu ((gritos e aplausos)) o termo o termo confisco não é não é o termo que a gente possa... que a gente possa utilizar nesse caso... confisco é um termo... que a gente que a gente usa né?... para dizer éh::::de um ato de um gesto de se tomar alguma coisa e não se devolver... então na questão dos ativos no bloqueio dos ativos não houve confisco porque todos esse recursos foram devolvidos até o último centavo... né? ((gritos)) remunerando isso com juros e correção monetária acima da::da inflação (gritos)... bom... bom como eu já disse como eu já disse a vocês é preciso também que a gente veja o momento em que isso foi foi feito não é... quer dizer... naquele momento em que eu assumi... havia... havia uma inflação de noventa porcento ao mês... havia portanto uma inflação de três porcento ao dia... havia um excesso de moedas em circulação... e nós para iniciarmos o governo e implantarmos o nosso programa econômico... nós tínhamos que criar estabelecer um um espaço um momento para de tranqüilidade no que diz respeito à inflação para aplicarmos o nosso programa... a inflação para o mês de abril estava prevista para chegar a quase duzentos porcentos e aí isso seria uma loucura... bom... então o que... que nós e::: fizemos na::ah::ah:: no:: no nosso projeto passava por um congelamento temporário de preços ou seja... para combater a inflação... nós temos que dar um congelamento temporário de preços... para exatamente os preços parassem de crescer e para que nós pudéssemos aplicar as medidas... no entanto... com aquela inflação alta e de repente os preços param de subir... o que que 695 aconteceria com todos aqueles que tivessem com o seu dinheiro... a primeira idéia o primeiro gesto o primeiro impulso era de ir para o consumo... ou seja aquela geladeira que deixou de ser comprada o liquidificador que não foi comprado o sofá ou isso ou aquilo... ia tudo isso para o consumo porque de repente... a população ver/verificaria que poxa os preços pararam de crescer... vamos consumir... e esse consumo seria um consumo violento... o que quebraria todo o sistema financeiro e também o sistema produtivo é ah: a questão do bloqueio foi uma medida de urgência e de emergência é:: de urgência urgentíssima e de emergência que foi tomada exatamente para evitar que isso não acontecesse ah:: naturalmente se vocês me perguntam é... faria isso de novo NÂO eu não faria isso de novo e contraria qualquer outra medida... ((gritos)) porque causou porque causou isso que vocês estão dizendo causou desassossego causou angustia e::: causou sem dúvida nenhuma um trauma na sociedade brasileira 
710 L1: é:: o tempo acabou::: infelizmente... tem muitas perguntas... a serem feitas eu sei... o tempo acabou... olha o:::s troncos aqui... dos telefones congestionaram todos... teria algum telefone para que as pessoas pudessem... a gente... vai dar as perguntas... ao senhor e talvez o senhor possa responder... mas de qualquer maneira... eu queria agradece a

715 vinda... ao Programa Livre e reiterar... se... outra vez for possível que voltasse porque:: muita gente... ficou com (vontade)

L2: olha quantas vezes quantas vezes Sérgio havendo oportunidade é com muito prazer que eu voltarei aqui para continuar ah... esse debate

L1: $\quad$ bom... obrigado vocês por terem vindo... muito obrigado pelas... perguntas... até amanhã com mais um Programa Livre tchau 


\section{ANEXO E}

Reprodução da entrevista concedida à repórter Neuza Sanches e publicada na página eletrônica da revista Istoé Gente, na edição de número setenta e quatro do final de 2000, quando se encerrava o período de oito anos de afastamento político a que foi condenado por consequência do Impeachment, acessada em 27/02/2010 pelo link http://www.terra.com.br/istoegente/74/entrevista/index.htm.

13

\footnotetext{
${ }^{13}$ Houve contato com a jornalista Neuza Sanches por meio de correio eletrônico, para questionamento em relação a uma possível edição da entrevista com a substituição de algum termo, especificamente os metafóricos como "cobra sem veneno", e a resposta literal da jornalista foi "Se está na matéria assinada por mim, é porque ele falou."
} 


\section{Fernando Collor}

\section{"Não posso errar"}

Para comemorar o fim da imposição legal que o manteve longe da política por oito anos, o ex-presidente faz festa para 500 convidados e anuncia candidatura ao Senado por Alagoas, enquanto aguarda o nascimento de seu quarto filho

\section{Neuza Sanches}

Chegaram ao fim os oito anos de abstinência política a que Fernando Collor foi condenado durante o processo de impeachment. A resolução número 101 do Senado Federal o privou de exercer qualquer função pública desde a manhã de 29 de dezembro de 1992. "Eram longos oito anos", lembrou Collor na tarde da quarta-feira 20, em entrevista a Gente. "E agora vejo que eles passaram rápido."

Aos 51 anos, o ex-presidente planeja minuciosamente seus próximos passos. Quer voltar um dia ao Palácio do Planalto. Antes disso, porém, pensa em conseguir assento no plenário azul-turquesa do Senado. "Se não der para ser candidato à Presidência, vou tentar ser senador por Alagoas", revelou à Gente.

Depois de tentar disputar a prefeitura de São Paulo, onde foi derrotado nas pesquisas de opinião e numa batalha jurídica que visava antecipar seu retorno, Collor vai ser pai novamente. Com três rapazes na família - Arnon Affonso, 24 anos,

Joaquim Pedro, 21 anos, Fernando James, 20 anos -, ele torce na surdina para que nasça Maria Fernanda. Rosane Collor, 36 anos, sua mulher, está grávida há dez semanas e em duas saberá o sexo do bebê.

Nos primeiros anos de ostracismo, Collor se exilou na Casa da Dinda, em Brasília, onde encerrou a depressão iniciada no processo de impeachment e que o fez

definhar 15 quilos. Depois, foi para Miami, onde ainda mantém residência, e voltou à musculação e à corrida três vezes por semana, recuperando os 87 quilos para 1,87 metro de altura.

Sempre acompanhou as manchetes dos principais diários. Sobre a cabeceira de sua cama, estão A Festa do Bode, de Vargas Llosa, e O Reino e o Poder, de Gay Talese. Um trata de um presidente autoritário, o outro de futricas da imprensa. A sesta de 20 minutos diários após o almoço é marco para que o ex-presidente inicie suas atividades diárias como palestras, encontros com correligionários e conversas, por telefone, com executivos do Grupo Arnon de Melo. "Estou pronto para voltar."

\section{Os oitos anos em que o senhor teve de ficar fora da vida pública}

É a retomada da minha vida política. Vou dar uma festa para 500 pessoas no dia 29. Farei um discurso para marcar a minha volta. 


\section{A sua antiga equipe de governo será convidada?}

Não convidei ninguém. Até porque não sou eu quem está fazendo a organização da festa. É um amigo de Maceió o responsável por tudo.

\section{Nesses oito anos fora da política, houve momentos de depressão?}

Eu não imaginava ultrapassar esses oito anos. Quando recebi a sanção, eu pensei: "Eu não vou suportar ficar oito anos sem poder exercer a função pública e sem poder continuar a minha carreira política". Eram longos oito anos. Hoje eu digo: "Tenho um projeto político para o novo milênio". E hoje vejo que eles passaram rápido.

\section{Qual foi o pior momento?}

Passei dois anos, logo depois da minha saída do governo, em que eu não conseguia dormir antes das sete da manhã. Foi na época em que ainda morava na Casa da Dinda, em Brasília. Assistia a todos os noticiários, lia compulsivamente os jornais. Eu chorava. Tinha abatimento profundo. Um político sem mandato é como uma cobra sem veneno.

\section{Como era seu dia-a-dia?}

Emagreci 15 quilos na fase do impeachment. Parei com tudo o que eu fazia. Acabei engordando. Não fazia exercício algum. Não tinha ânimo pra nada. Quando saí da Presidência tinha 75 quilos. O meu peso normal é de 87 quilos.

\section{senhor sente mágoa de quem não ficou ao seu lado?}

Perdoei a todos. Não presto essa homenagem aos meus adversários de então, guardando deles sentimentos como mágoa. Em política nunca podemos dizer que temos amigos para o resto da vida e inimigos irreconciliáveis. Ser político é uma atividade extremamente solitária. O que deve ser levado em conta é Piti Reali que em política não existem amigos. Existem aliados.

\section{E estar fora da política?}

É mais solitário. Os dois anos depois que saí do governo, foram os piores de minha vida. Eu não acredito em inferno, na concepção comum que as pessoas crêem. Acho que o inferno é o que a gente vive aqui mesmo. Mas essa concepção de inferno, eu vivi nesses dois anos.

\section{Rosane Collor está grávida de dez semanas. Escolheram o nome do bebê?}

Se for menina, será Maria Fernanda. Não pensamos no nome, se for homem. Isso mostra a torcida pelo sexo.

\section{Já realiza todos os desejos dela?}

Não tão exacerbado assim. A mulher grávida fica mais sensível. Então

eu tomo muito cuidado nas coisas que falo. Desejos, ela ainda não entrou nessa fase. Mas eu pego no pé para ficar mais em repouso. E

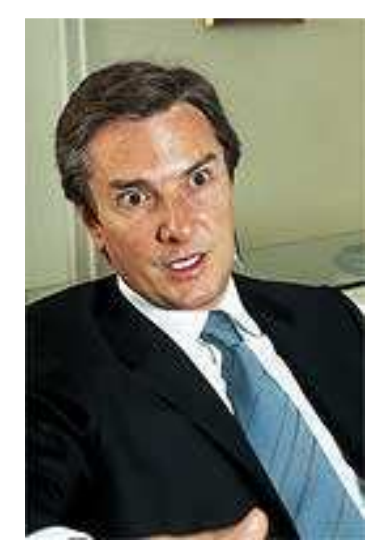

"Itamar é carente. Tem temperamento de uma prima-dona de ópera. Se ofende por qualquer coisa" vou a todas as visitas médicas. Acompanho tudo.

\section{O senhor vai continuar morando em São Paulo?}

Em meados de janeiro, nós vamos retomar a busca por uma casa em São Paulo.

\section{Vai novamente ser candidato?}

Acalento o sonho e o desejo de voltar à Presidência da República. Mas não sofro 
nem da ansiedade

e nem da angústia, própria daqueles que almejam a residência e que por lá ainda não passaram. Tenho tempo para amadurecer essa idéia. Não posso errar. Se não for candidato em 2002, posso ser em 2006, 2010, 2014 ou 2018, quando terei a idade do atual presidente Fernando Henrique Cardoso.

\section{Se não for candidato à Presidência, vai concorrer a outro cargo?}

Tentarei o Senado por Alagoas, onde eu comecei a minha história política.

\section{O senhor não será mais candidato por São Paulo?}

A minha vinda para São Paulo prova que eu não estava atrás de um mandato. Se assim fosse, eu tentaria ser eleito em Alagoas. São Paulo detém as forças econômica e política. Antigamente, o peso político estava dividido entre Minas Gerais, Rio, Rio Grande do Sul e São Paulo. E hoje os grandes partidos, os maiores políticos e os principais debates estão em São Paulo. Assim, vim para cá para mostrar que estou com a alma lavada, tranqüila e com o mesmo ímpeto. Embora com muito mais ponderação, experiência e amadurecimento.

\section{E por que o Senado?}

Nas democracias ocidentais o caminho natural de ex-presidentes é o Senado. A única exceção é nos Estados Unidos, onde o ex-presidente é mumificado em vida. Ganha uma biblioteca e cinco seguranças e não pode ser mais nada e vai fazer palestras. Se eu tivesse cumprido o meu mandato, teria tentado o Senado, em 1998. Houve uma interrupção política, que agora estou retomando.

\section{Qual a sua avaliação sobre o governo Fernando Henrique?}

110 Até 1998, ele foi correto, bem intencionado. Teve uma relação boa com o Congresso e fez o dever de casa. A partir daí, ele priorizou projetos de interesse pessoal como a emenda constitucional que permitiria a reeleição em detrimento de projetos de interesse nacional, das grandes reformas, como a tributária e a previdenciária. Nesse momento ele se vulgarizou e estabeleceu uma relação subalterna com o Congresso Nacional.

\section{O senhor escreveu um livro de memórias. Ele está pronto?}

Terminei e irei publicar em algum momento. Mas agora não vou lançá-lo.

\section{Por quê?}

Eu segui o conselho do ministro Tales Ramalho (ex-ministro do Tribunal de Contas da União). Ele disse que um livro de memórias escreve quem está pela hora da morte. Mas, apresentei a ele os primeiros capítulos e ele me disse: "O senhor não pode publicar isso". Disse ainda que isso iria desmascarar muita gente e que causaria problemas para as famílias dos personagens. Para ele está na hora de eu aglutinar apoios e não dividi-los.

\section{O que há de bombástico?}

Nas 680 páginas há a saga da minha família e a parte mais quente, quando eu conto histórias sobre a minha relação com os 40 personagens com quem convivi

nos dois anos em que estive no Planalto. Traz as minhas impressões, o que eu acho que eles fizeram de bem e o que fizeram de errado. 
130 Quem são esses personagens?

Oitenta por cento são políticos e outros 20 por cento empresários. Alguns já morreram. Mas não quero falar de nomes.

\section{Há banqueiros?}

Não.

135 O senhor poderia citar pelo menos os que morreram?

Há histórias com Ulysses Guimarães, Márcia Kubitschek e o presidente João Figueiredo. Sobre ele, por exemplo, falo da minha boa experiência do ponto de vista pessoal.

E o que o senhor acha do governador de Minas Gerais, Itamar Franco, seu antigo vice-presidente da República?

É uma pessoa absolutamente carente de afeto. A pessoa quando é carente se ofende muito por qualquer coisa. Ele tem temperamento de uma prima-dona de ópera. Eu confesso que não acompanho o desempenho do governo dele.

Acompanhei só quando ele colocou uns brucutus da Polícia Militar no Palácio e eu

145 não entendi o porquê daquilo. Depois foi o caso também das manobras militares. São coisas que para mim soam esquisitas.

O governador Itamar Franco é um dos seus personagens?

É, sim. Pronto, você conseguiu um nome. 


\section{ANEXO F}

Reprodução do discurso de posse no Congresso Nacional, em Brasília, como senador pelo estado de Alagoas, em 15 de março de 2007, assim como publicada na página eletrônica do Senado Federal e que foi acessada em 27/02/2010 pelo link http://www.senado.gov.br/sf/atividade/pronunciamento/detTexto.asp?t=367005.

14

Tal reprodução inclui os apartes de outros locutores presentes no plenário na ocasião do discurso, grifados para diferenciá-los da fala de Fernando Collor e destacados os nomes dos locutores para melhor visualização.

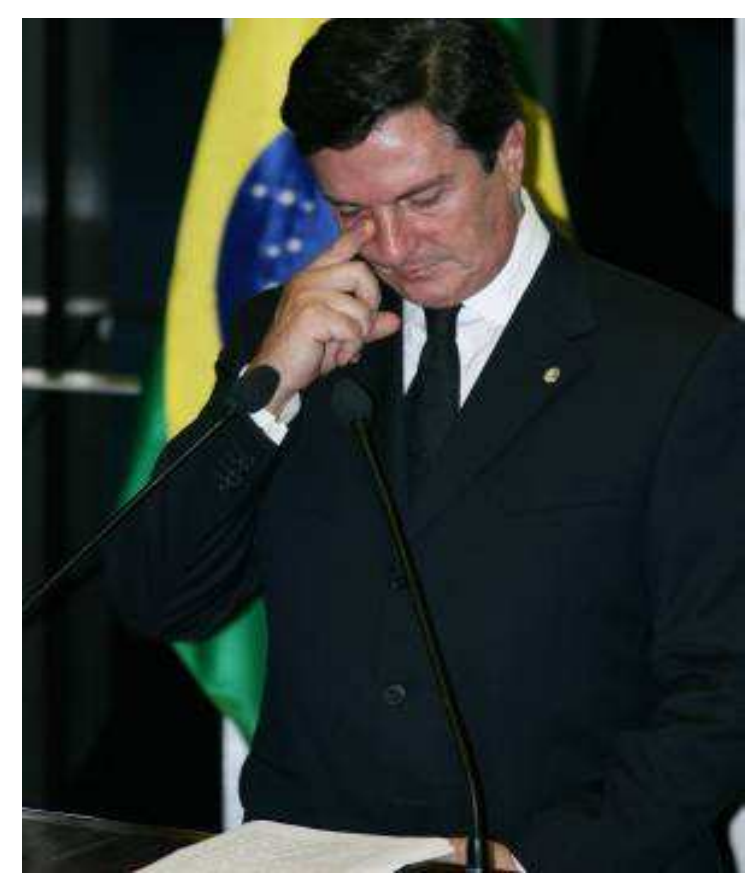

Collor chora após o discurso de posse como senador em 15/03/2007

\footnotetext{
${ }^{14}$ Há outras versões deste discurso, uma delas na página pessoal de Fernando Collor, porém foi tomada a decisão de analisar-se a versão publicada na página do Senado, pois, sendo esta de responsabilidade do próprio senado, em tese, seria mais próxima da que foi efetivamente pronunciada por Fernando Collor no dia de sua posse como senador.
} 
Atividade Legislativa

31 de agosto de 2009

Pronunciamentos

Texto integral

1 1 voltar

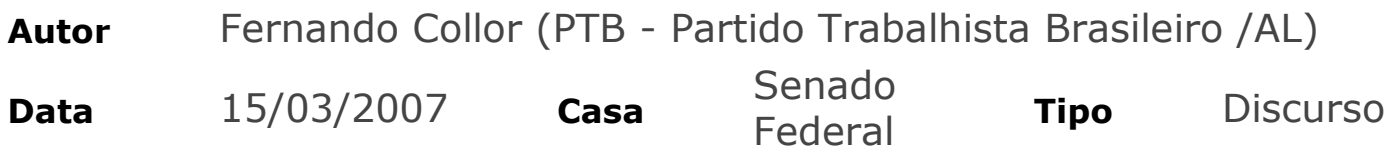

O SR. FERNANDO COLLOR (Bloco/PTB ¿ AL. Pronuncia o seguinte discurso. Sem revisão do orador.) ¿ Sr. Presidente do Senado Federal, Senador Renan Calheiros, $\mathrm{Sr}^{\mathrm{a}} \mathrm{s}$ e Srs. Senadores, os episódios que aqui vou rememorar obrigaram-me a padecer calado e causaram mossas na minha alma e cicatrizes no meu coração. Se o sofrimento e as injustiças provocam dor e amargura, podem também nos trazer úteis e até proveitosas lições. Ambos nos ensinam a valorizar a grandeza dos justos e a justiça dos íntegros. As agruras terminam retemperadas pela lealdade dos amigos e pela solidez das verdadeiras amizades. Graças a essas qualidades que aprendi admirar, posso hoje, Sr. Presidente, Sras e Srs. Senadores, sem sentimentos subalternos de qualquer natureza, abrir minha alma e meu coração, esperando de $\mathrm{V}$. Exas a compreensão e a paciência que espero não me faltem. Não é fácil volver os olhos ao passado e reviver, em toda sua extensão, a tortura, a angústia e o sofrimento de quem, agredido moralmente, acusado sem provas e insultado e humilhado durante meses a fio, teve que suportar as agruras de acusações infundadas e a condenação antes mesmo de qualquer julgamento. As provações que o destino nos reserva são amenizadas na vida privada pelo calor do conforto, do carinho e do consolo dos que nos cercam ante as adversidades de nossa existência; mas as da vida pública, essas têm que ser suportadas com resignação e silêncio, especialmente quando insufladas pelas paixões e alimentadas pelo fragor das ruas, insufladas pela cegueira das emoções.

Nos momentos mais dramáticos desse processo, pude ponderar sobre os fastos de nossa história política, recordando a abdicação imposta a D. Pedro I, a deposição e o exílio de seu filho e sucessor, D. Pedro II, e o desencanto que levou Deodoro a renunciar à Presidência da República que ele proclamou. Por minha mente perpassaram a deposição e a extradição de Washington Luís, o suicídio do Presidente Vargas, o impedimento declarado sem processo pela Câmara de seu sucessor, Café Filho, e do substituto Carlos Luz. Recordei-me da renúncia de Jânio Quadros e da ação que depôs João Goulart e Ihe impôs o exílio em que faleceu. Com isso, Sr. Presidente, pude concluir como os atos de força tornaram-se quase uma rotina periódica de nossa história política.

Exatamente por tudo quanto passei, devo trazer a verdade dos atos que redundaram no meu afastamento da Presidência da República. Espero virar esta página de minha carreira política no momento em que a retomo com o propósito de contribuir, na medida de minhas possibilidades, para o progresso e o bem-estar do País e o aprimoramento de seu sistema político.

Hoje, passados 17 anos de minha posse na Presidência da República, volto à atividade política, integrando esta augusta Casa, a mesma que a interrompeu por decisão dos ilustres membros que a compunham na 49a Legislatura.

Ao fazer este depoimento, cumpro menos um dever pessoal do que um imperativo de consciência. Não foram poucas as versões, mais variadas ainda as interpretações e não menos generalizadas as explicações. Eu o farei mais sobre os atos do que sobre os fatos que levaram, primeiro, ao meu afastamento do Governo e, depois, à minha renúncia em decorrência do primeiro processo de impeachment de um Chefe de Governo, que teve curso e conseqüência em nossa mais que 
centenária República.

Confrangido algumas vezes, contrafeito outras, mas calado sempre, assisti, ouvi, suportei acusações, doestos e incriminações dos que, movidos pelo rancor, aceitaram o papel que Ihes foi destinado na grande farsa que Ihes coube protagonizar.

50 Nesses 15 anos de minha paciente espera, o País tomou conhecimento de diversas versões de alguns dos figurantes daqueles dramáticos e amargos momentos.

Ficaram faltando, Sr. Presidente, o testemunho e o depoimento de quem, com certo estoicismo e muita resignação, mas sem nunca perder a fé, enfrentou aqueles lamentáveis episódios de nossa história política.

55 Hoje, desta tribuna $\dot{c}$ a quinta, a mim proporcionada pelo voto e pela generosidade do povo alagoano $\dot{c}$, é chegado o momento de falar à Nação, para mostrar, com serena tranqüilidade, os descaminhos de um processo que, seguramente, não honra nem dignifica a história parlamentar de nosso País.

Tratando, em sua obra única e pioneira, sobre o instituto jurídico contra mim acionado em 1992, o gaúcho Paulo Brossard, constitucionalista, ex-Senador e exMinistro do Supremo Tribunal Federal, já prevenia, há mais de quarenta anos, contra os abusos que o impeachment pode propiciar: ¿Tendo-se em conta que incontrastáveis, absolutas e definitivas são as decisões do Senado, dir-se-á que pode sobrevir a prática de muitos e irreparáveis abusos, assim pela Câmara, que acusa, como e notadamente pelo Senado, que julga, de modo irrecorrível e irreversíveli.

A crônica do processo contra mim intentado foi, como provarei, uma litania de abusos e preconceitos, uma sucessão de ultrajes e um acúmulo de violações das mais comezinhas normas legais, uma sucessão, enfim, de afrontas ao Estado de

70 Direito democrático, como demonstrarei.

A advertência de Paulo Brossard jamais chegou aos ouvidos dos responsáveis pela série de arbítrios que toldaram a aplicação de um dos mais importantes institutos jurídicos no âmbito do Direito Público, em especial de nosso Direito Constitucional legislado.

75 Esses abusos, que se multiplicaram a partir do procedimento intentado contra mim no exercício do cargo de Presidente da República, acentuaram-se de tal maneira que, no livro recentemente publicado Criação de Comissões Parlamentares de Inquérito ¿ tensão entre o Direito Constitucional de minorias e os interesses políticos da maioria, o consultor legislativo deste Senado, Marcos Evandro Cardoso

80 Santi julgou relevante assinalar que: ¿A grande concentração de poderes das CPIs não só originou o sucesso de muitas delas, como facilitou abusos por parte de seus integrantesi.

Vamos aos fatos, Sr. Presidente, Sras e Srs. Senadores.

Na quarta-feira, 27 de maio de 1992, subscrito por eminentes Deputados e

Senadores de diferentes Partidos, foi lido o requerimento preconizando a criação de uma comissão parlamentar mista de inquérito destinada a, no prazo de até 45 dias, apurar fatos contidos nas denúncias do Sr. Pedro Collor de Mello, referentes às atividades do Sr. Paulo César Cavalcante Farias, capazes de configurar ilicitude penal. Instalada na segunda feira, 10 de junho, devia encerrar seus trabalhos na quarta-feira, 28 de agosto. Composta de 11 Senadores, 11 Deputados e igual número de suplentes, a CPMI foi presidida pelo Deputado Benito Gama, e teve como Vice-Presidente e Relator, respectivamente, os então Senadores Maurício Corrêa e Amir Lando. Foram realizadas 35 reuniões, as últimas das quais, na terçafeira, 11 de agosto, data em que foram discutidas, votadas e aprovadas as respectivas atas. Ouviram-se 23 testemunhas, e foram autuados 130 documentos. Em nenhum dos depoimentos, nem em qualquer dos documentos arrolados, há qualquer acusação contra mim, pessoalmente, nem contra qualquer ato que eu tivesse praticado como Presidente da República.

No dia 23 de agosto, cinco dias, portanto, antes do término do prazo que lhe foi 100 assinado, o ilustre Relator submeteu à Comissão seu parecer, imputando ao Presidente da República: 
Ilícitos penais comuns, em relação aos quais a iniciativa processual é prerrogativa intransferível do Ministério Público. Por outro lado [são ainda palavras do Relator], podem configurar crime de responsabilidade em relação aos quais a iniciativa processual é prerrogativa da cidadania perante a Câmara dos Deputados, já que as omissões do dever presidencial de zelar pela moralidade pública e os bons costumes são especialmente tratados por esta Constituição Federal.

Os abusos que podem ser praticados pelas comissões parlamentares de inquérito, Sr. Presidente, Sras Senadoras e Srs. Senadores, e aos quais aludem Paulo

110 Brossard e Marcos Evandro Cardoso Santi, nos livros já citados, podem ser evidenciados, não direi na leviandade, mas pelo menos na incoerência do eminente Relator, imputando-me ilícitos penais que, em suas próprias palavras, ¿podem configurar crimes de responsabilidade $\dot{c}$, quando, na síntese dos depoimentos $\dot{c}$ página 92 do relatório $\dot{c}$, ele transcreve o teor das afirmações de meu irmão Pedro, 115 assim por ele resumidas:

Em conversa com José Barbosa de Oliveira, os ex-Governadores Moacir Andrade e Carlos Mendonça, em diferentes ocasiões, Paulo César Cavalcante Farias teria dito que mantinha uma sociedade informal com o Presidente da República, a quem transferia $70 \%$ dos lucros. Esse detalhe [ainda são palavras do Relator] é

120 relevante. Primeiro, porque, se a sociedade existe, investigar as atividades de Paulo César implica em investigar a do seu sócio, para cujo efeito esta CPI não dispõe de poderes.(sic)

Se a Comissão de que S. Exa foi Relator não dispunha de poderes para investigar o Presidente da República, como poderia imputar-me delitos que não cometi, crimes

125 que não pratiquei, e que S. Exa não indicou, não especificou nem sequer tipificou. Tal como ocorreria depois, na sucessão de atos exorbitantes, a CPMI começou por violar o art. 86, §40, da Constituição, segundo qual, o Presidente da República, na vigência de seu mandato, não pode ser responsabilizado por atos estranhos ao exercício de suas funções.

130 Ora, Sr. Presidente, Sras e Srs. Senadores, se não fui investigado, se não fui notificado, se não fui indiciado, como poderiam a Comissão e seu Relator acusar quem não foi sequer objeto de investigação? Se havia atos por mim praticados que, mesmo em tese, pudessem caracterizar crimes de responsabilidade ou crimes funcionais, por que não apontá-los, por que não indicá-los e por que não levá-los

135 ao Ministério Público, titular da ação penal?

Essa demonstração patente de imprudência, contudo, foi apenas o começo da série interminável de excessos cometidos ao arrepio da lei, à margem do direito e contra a letra e o espírito da Constituição.

O pressuposto em que se apoiou o Relator era o de que Paulo César Farias ¿teria

140 ditoc a três honrados e ilibados cidadãos que manteria comigo uma sociedade informal, pela qual me transferia $70 \%$ dos cंlucrosi.

Por que nem sequer se animou $\mathrm{S}$. Exa a ouvir dessas pessoas se efetivamente isso Ihes foi dito? Por que Paulo César Farias não foi indagado a respeito em seu depoimento? Pela simples razão, Sr. Presidente, Sras e Srs. Senadores, de que a

145 CPMI não cuidava de investigar-me, o que não era seu objeto, mas de incriminarme, mesmo sem provas, indícios ou evidências. O resultado é que, a partir de uma suposição, criou-se uma infâmia, e sobre essa infâmia, acolhida por S. Exa, o Relator, construiu-se um arrazoado de suposições igualmente caluniosas e, depois, como ficou comprovado, sabidamente falsas.

150 A falsidade, Sr. Presidente, sempre foi um recurso condenável e deletério, lamentavelmente utilizado na política brasileira, com maior ou menor freqüência, segundo os interesses nela envolvidos. Dela foi vítima o ex-Presidente e homem público Arthur Bernardes, objeto das cartas falsificadas por conhecido delinqüente para tentar intrigá-lo com as Forças Armadas, quando ainda candidato à

155 Presidência da República. Por meio dela, materializada no famoso Plano Cohen, justificou-se o golpe o Estado Novo e por ela se tentou imputar ao ex-Presidente João Goulart crimes que não praticou, falsidade em que foi utilizado outro meliante, 
autor da deprimente Carta Brandi. Pedidos de impeachment contra os Presidentes da República transformaram-se em uma atividade rotineira em nosso

160 presidencialismo.

Todos os Chefes de Governo sob a Constituição de 1946, à exceção do Marechal Dutra e do Presidente Jânio Quadros, e todos os demais depois do fim do regime militar foram objeto desse procedimento. Alguns subscritos por parlamentares, outros, por anônimos em busca de notoriedade. Tanto o Presidente Vargas quanto alguns de seus Ministros foram alvo de numerosas tentativas, mas tiveram os pedidos que Ihes diziam respeito, invariavelmente, rejeitados. O mesmo ocorreu com o Presidente Juscelino Kubitscheck. Depois do regime militar, o Presidente José Sarney foi a primeira vítima desse expediente. Meu substituto, que por esse processo tornou-se meu sucessor, teve duas tentativas rejeitadas pelo Presidente 170 da Câmara. Contra o Presidente Fernando Henrique Cardoso, foram apresentados nada menos que vinte e seis pedidos de impeachment, sendo cinco subscritos por deputados. Contra o Presidente Lula, em seu primeiro mandato, intentaram-se vinte e oito representações, sendo apenas uma de parlamentar, as demais de cidadãos, além de uma outra representação no mandato atual.

175 Em nenhum desses casos as iniciativas prosperaram. A indagação cabível em face desses precedentes é, necessariamente, apenas uma: por que até hoje, mais de sessenta anos depois da Constituição de 46, apenas contra meu governo se deu curso a essa espúria representação?

Trata-se de um patético documento aceito sem qualquer discussão, sem qualquer 180 ponderação, sem qualquer cautela, sem qualquer isenção e com total ausência de equilíbrio e serenidade. Enfim, uma ¿denúncią articulada por dois cidadãos cujas provas se resumiram a dois de meus pronunciamentos no rádio e na televisão e a duas cartas firmadas por meu Chefe de Gabinete e por uma de minhas secretárias, todos documentos públicos utilizados em minha própria defesa.

185 A resposta pode não ser óbvia, mas os fatos e as circunstâncias que determinaram sua aceitação deixam claros os interesses e os propósitos que contra mim se moveram.

A primeira eleição direta para a Presidência da República depois do regime militar foi, como era natural, a mais concorrida, a mais disputada e a que maior número

190 de postulantes teve no País até hoje. Foram nada menos de vinte e um candidatos, muitos de longa, brilhante e tradicional atuação na vida pública, apoiados, esses vinte e um candidatos, por vinte e sete diferentes legendas.

Concorri por uma coligação de três pequenos partidos que, nas eleições de 86 , não tinham obtido uma só cadeira na Câmara, composta então de 487 integrantes e na

195 qual os dois maiores partidos coligados, PMDB e PFL, dispunham de 77,6\% da representação nacional.

Nas eleições de 90, no primeiro ano de meu governo, numa Câmara já então com 503 Deputados, o PRN, legenda pela qual concorri à Presidência da República, logrou conquistar quarenta cadeiras e o PST, que integrou minha coligação no

200 pleito presidencial, apenas duas. Juntos, somavam $8,4 \%$ do total. Ante esses números, sempre tive consciência da fragilidade do apoio político, parlamentar e partidário de que poderia dispor quando me elegi.

Por isso, vencido ¿o prélio pacifico das urnaṧ, na feliz expressão de João Neves da Fontoura, acreditei superadas as diferenças e ressentimentos que toda vitória

205 desperta nos derrotados e que todas as derrotas provocam nos vencidos. É do conhecimento de todo o País o esforço que empreendi e o empenho que empreguei para compor meu governo de apenas doze ministérios, com correligionários e integrantes de alguns dos 24 partidos com os quais competi pela Presidência.

210 Encerrada a apuração, era preciso ensarilhar as armas do embate eleitoral e buscar a cooperação dos adversários, que sempre respeitei e que sempre encarei apenas como concorrentes, jamais como inimigos. Propus um entendimento com o PSDB por intermédio de seu presidente, Senador Franco Montoro, convidando para as 
duas áreas vitais de qualquer governo, a da Fazenda, o então Deputado José Serra e, para a área das Relações Exteriores, o então Senador Fernando Henrique Cardoso. A da Fazenda, pela situação de moratória em que se encontrava o País em face de nossa situação econômica, como de resto outros países também; e a das Relações Exteriores, para o desafio de reinserir o Brasil no novo contexto internacional depois da queda do Muro de Berlim.

220 Que demonstração mais cabal, Sr. Presidente, Sras e Srs. Senadores, poderia ter dado de minhas intenções de fazer um governo transparente, de reta intenção, sem preconceitos, sem mágoas e sem ressentimentos, com os olhos postos apenas no futuro?

A despeito de meus esforços, o entendimento que busquei não se concretizou. Não

225 por falta de iniciativa e de empenho de minha parte, mas pelo fato de o acordo, depois de fechado e sacramentado, ter sido rompido de forma abrupta por exigência de um de seus próceres.

Tomei posse em 15 de março de 1990, com uma Câmara eleita em 1986 e na qual o partido com maior representação, o PMDB, contava com $53,4 \%$ das cadeiras. Os

230 Deputados distribuíam-se em oito legendas, uma dispersão partidária superada em 1954, o ano do suicídio do Presidente Vargas, e, em 1962, nas últimas eleições antes de 1964, quando 13 partidos estiveram representados naquela Casa do Congresso.

Foram, como se sabe, dois períodos de crise política e institucional. Além do mais, 235 iniciei meu governo faltando menos de sete meses para o pleito que deveria renovar a legislatura a ser encerrada em 31 de janeiro seguinte. As urnas mostraram o maior índice de fracionalização já verificado com a representação na Câmara, dividida em 19 partidos, índice então e até hoje não superado. Em um ambiente partidário tão fragmentado, a formação de um governo de 240 coalizão tornou-se ainda mais difícil. Ante tantos interesses em conflito, minhas dificuldades se acentuaram logo no início da nova legislatura, em fevereiro de 1991. Encontrar equilíbrio, serenidade, moderação e prudência em um ambiente dessa natureza era tarefa quase impossível. O radicalismo e a intolerância tornaram-se moeda de curso fácil.

245 Em reportagem publicada na edição de 27 de janeiro deste ano de 2007, no jornal O Globo, os jornalistas João Domingos e Luciana Nunes Leal, referindo-se à importância do cargo de Presidência da Câmara, escreveram:

Em fevereiro de 1991, o Deputado Ibsen Pinheiro assumiu a Presidência da Câmara. Não se dava, então, com o Presidente Collor, que [está literalmente]

250 sempre fazia ameaças. A Câmara iniciou os seus trabalhos no dia 15, uma sextafeira, sem votação. Na terça-feira, dia 19 [continua a matéria desses jornalistas], Ibsen sacou um projeto do então Deputado Nelson Jobim que tirava poderes de edição de medidas provisórias do Presidente da República e o votou.

Continuam os repórteres: ¿Collor tomou um susto. Conseguiu brecá-lo no Senado,

255 onde tinha maioria. Um ano e meio depois, foi ele quem autorizou a abertura do processo de impeachmenti.

Embora eu fosse à época e tenha sido até hoje o titular da Presidência que proporcionalmente menos medidas provisórias editou, sei que estava sendo testado. Não eu, Sr. Presidente, não eu, Sras e Srs. Senadores, não eu, mas

260 terceiros foram os que constataram o que na época já era público: a animosidade gratuita que aquele representante votava contra mim. Sua atuação terminou por transformar o instituto do impeachment, que é um remédio jurídico e político contra graves crises institucionais, num instrumento de vingança política, de afirmação pessoal e de desforra particular. Triste fim, Sr. Presidente, para um 265 instituto destinado, em sua origem, à proteção das nobres causas da defesa da normalidade democrática e da preservação do Estado de Direito.

$O$ requerimento de instauração de processo contra mim foi subscrito, à semelhança de dezenas de outros que chegaram aos sucessivos presidentes da Câmara, por dois zelosos cidadãos movidos por impulsos que não me cabe julgar. Acusaram-me 
270 de falta de decoro no exercício da Presidência e invocaram a lição de Cícero, segundo a qual, ¿ao trazer aos fatos da vida uma certa ordem e medida, conservamos a vida e o decoro $\dot{c}$, acrescentando que essa ordem e medida na vida pessoal traduzem-se pelo recato, a temperança, a modéstia, o domínio das paixões e a ponderação em todas as coisas, para concluírem que não há decoro separado 275 da honestidade, pois o que é decente é honesto e vice-versa.

A invocação do grande orador e senador romano pode até ter sido adequada, mas, sem dúvida, foi também absolutamente equivocada. Aludindo a Marco Túlio Cícero deviam estar pensando na conspiração de Catilina, mas o conspirador, Sras e Srs. Senadores, não era o Presidente da República, que cumpriu até o fim o seu papel 280 constitucional nos estritos limites da lei e da ordem jurídica democrática vigentes no país.

Conspiradores eram os que não mediam esforços para afastá-lo do poder, quaisquer que fossem os recursos empregados. O documento que os autores da representação produziram não era uma catilinária, mas uma verrina, definida pelo

285 Aurélio como cada um dos discursos de Cícero contra Caio Verres. Trata-se de uma palavra que, em nosso vernáculo, adquiriu o significado daquilo que efetivamente é um documento elaborado por um e subscrito pelos dois signatários. Significa crítica apaixonada e violenta.

Talvez tivessem sido mais fiéis à História e à realidade se invocassem não Cícero, o

290 Senador, mas Catão, o Censor, que, temendo a prosperidade de Cartago, tornou-se conhecido pela invectiva Delenda Carthago ¿ Cartago deve ser destruída. A Cartago contra quem remetiam, porém, era a cidadela da legalidade, de que nunca me afastei e a que me submeti, até mesmo na adversidade, quando a injustiça, o arbítrio e a prepotência dos inconformados se voltaram contra mim.

295 Aquele não era o primeiro, mas o segundo ato de uma farsa em que, lamentavelmente, a arrogância se tornou um instrumento da política no País, que Sérgio Buarque de Holanda classificou como ¿A pátria do homem cordiali. Nas 20 páginas da representação que os autores denominaram de denúncia, a infração legal de que me acusaram foi a que se encontra tipificada no $\mathrm{n}^{0} 7 \mathrm{do}$ art.

$3008^{\circ}$ da Lei $n^{\circ} 1.079$, de 10 de abril de 1950, que define os crimes de responsabilidade e regula o respectivo processo de julgamento. Dispõe aquele dispositivo que são crimes contra a segurança interna do País: ¿permitir de forma expressa ou tácita a infração de lei federal de ordem públicaci.

Das 61 condutas delituosas que a lei tipifica como crime de responsabilidade

305 escolheram uma para acusar-me. O dispositivo alude a permitir ¿de forma expressa ou tácita, infração de lei federal de ordem públicac, ou seja, permitir por ação ou omissão a infração da lei federal, que os autores da representação, por sinal, não apontam qual seja.

Também, lamentavelmente, esqueceram de ressalvar que a única ação que

310 pratiquei em relação às denúncias de meu irmão não foi a de negar, ignorar ou me omitir ante os fatos apontados; ao contrário, foi a de determinar a sua imediata apuração pela Polícia Federal. Não esperei suas repercussões, não aguardei que me cobrassem providências. A afirmação sequer é minha; nem a invoquei em minha defesa. Pode ser lida no testemunho prestado sob juramento pelo hoje nosso

315 colega Senador Romeu Tuma, na Sessão do Senado, como órgão judiciário, do dia 29 de dezembro de 1992, publicada no Diário do Congresso Nacional, Seção 2, do dia 30 do mesmo mês e ano, às fls. 2.809 e seguintes.

S. Exa exerceu, em meu Governo, os cargos de Secretário da Receita Federal e Secretário da Polícia Federal, que, num curto período, acumulou também com o de

320 Diretor-Geral daquele órgão. Indagado pelo Presidente do Supremo Tribunal Federal, que presidia a sessão, se ¿recebeu ordens ou foi por iniciativa próprią que iniciou as investigações sobre as denúncias feitas por meu irmão, respondeu: Gostaria de explicar a pergunta. Com a denúncia do Sr. Pedro Collor, através da Revista Veja, que chegou às minhas mãos no sábado, no dia anterior à circulação normal de assinantes, ao lê-la, vislumbrei que havia notícias de crime no 
depoimento de Pedro Collor. Comuniquei imediatamente o fato ao Ministro Célio Borja e passei por fax a matéria, através da Superintendência do Rio de Janeiro. E ele me pediu, então, que aguardasse até segunda-feira, quando conversaria com o Presidente a respeito do assunto.

330 Continua o depoimento do Senador Romeu Tuma, à época Diretor-Geral da Polícia Federal.

Veio, depois, uma ordem determinando que se apurassem as denúncias configuradas na Revista Veja. Então, foi aberto o inquérito. E, paralelamente, chegou uma requisição de informações no mesmo sentido do Dr. Aristides

335 Junqueira pela Procuradoria. Encaminhei o assunto à Coordenação Judiciária e designamos o Dr. Paulo Lacerda para dar início às investigações através do inquérito policial.

Ante a pergunta do Dr. Inocêncio Mártires Coelho, feita em nome da defesa, de quem o então Diretor-Geral do Departamento de Polícia Federal tinha recebido a 340 ordem, em face da afirmação do Ministro Sidney Sanches de haver dito que foi do Ministro da Justiça, S. Exa respondeu mais uma vez: ¿Sim, do Ministro Célio Borja, que veio com ordem do Presidente da Repúblicac. A ordem de apurar os fatos denunciados e de cooperar sem restrições nas investigações não dei apenas ao Ministro da Justiça e ao Secretário da Polícia Federal, mas também ao Ministro da

345 Fazenda e, por seu intermédio à Receita Federal, e igualmente ao Presidente do Banco Central, cujos testemunhos encontram-se igualmente nos Anais do Senado. Depondo na Comissão desta Casa que processou o impeachment disse o exMinistro Marques Moreira em resposta ao Relator:

Nobre Senador, depois das revelações aparecidas, sobretudo numa revista, o

350 Senhor Presidente da República em um despacho matinal ¿ eu tinha quatro despachos semanais com Sua Excelência, dois despachos comuns com o Ministro da Justiça, às 9 da manhã, e dois à tarde $\dot{~ d e t e r m i n o u ~ a ~ m i m ~ e ~ a o ~ M i n i s t r o ~ d a ~ J u s t i c ̧ a, ~}$ o ex-Ministro Célio Borja, que imediatamente abríssemos as investigações no seio da Receita e colocássemos também o Banco Central à disposição da Receita, para

355 que toda a verdade seja revelada. Assisti ao Presidente determinando providências paralelas ao Sr. Ministro Célio Borja. Nós, inclusive, achamos que, sob a orientação do juiz, deveríamos promover um entrosamento entre a Polícia Federal, a Receita Federal e, quando necessário, o próprio Banco Central para que, cumprindo aquelas instruções do Presidente da República, toda a verdade pudesse ser revelada.

360 Permitam-me ler o expediente enviado, no dia 25 de maio de 1992, por mim ao Ministro da Justiça:

Sr. Ministro da Justiça, as denúncias veiculadas pela imprensa, no último fim de semana, envolvendo a minha pessoa na condução da administração pública federal são graves. Determino que seja instaurado competente inquérito policial, para que

365 se apurem os fatos em toda a sua extensão.

No mesmo dia, S. Exa o Ministro da Justiça exarou o seguinte despacho: ¿Ao Departamento de Polícia Federal para cumpriri. E seu diretor, o Delegado Amaury Aparecido Galdino, determinou: ¿Designo o DPF Paulo Fernando da Costa Lacerda para presidir o inquérito policiali.

370 A conclusão lógica, inevitável e irretorquível é a de que, ao contrário do que me acusaram, não permiti nem de forma tácita nem de forma expressa a violação de nenhuma lei federal de ordem pública.

Tomei imediatamente a iniciativa de determinar incontinente a apuração, sem ressalvas, de todos os fatos denunciados. Mais do que isso, ainda respondendo a

375 outras indagações, o então Diretor-Geral do DPF, em mais duas afirmações, assegurou: ¿Sei que, à medida que os fatos surgiam, o Ministro Célio Borja comentava que o Presidente pedia o aprofundamento das investigaçõesi. Essas foram expressões constantemente usadas pelo Ministro. E em seguida: ¿O Ministro Célio Borja repetia sempre que era para aprofundar, para apurar, e que o

380 Presidente pedia sempre velocidade no andamento dos processosi. Mais contundente impossível, Sr. Presidente! Agi não só de acordo e em 
consonância com a lei, mas segundo impunham minha consciência e minha formação, como, aliás, sempre atuei desde o primeiro dia do meu mandato. A representação com pedido de impeachment, firmada com data de terça-feira, $1^{\circ}$ de setembro de 1992, foi entregue no mesmo dia nas mãos dos Presidentes da Câmara dos Deputados e do Senado Federal, no Salão Negro, no edifício do Congresso Nacional, depois que procissão de abnegados cidadãos, cívica e idealisticamente convencidos da culpabilidade do Presidente da República, percorreu parte da Esplanada dos Ministérios, para, sob o olhar das câmaras de televisão, manifestar a sua indignação contra o Chefe do Governo.

O Presidente da Câmara dos Deputados antecipou que o pedido seria atendido, usando o conveniente e oportuno slogan de que ¿o que o povo quer, esta Casa acaba querendoi.

O Diário da Câmara dos Deputados, da mesma data, registra a informação

395 subscrita pelo Secretário-Geral da Mesa de não haver obstáculos regimentais ao curso do pedido e ao deferimento do Presidente da Câmara dos Deputados, para que a representação tramitasse sem mais exigências, afirmando textualmente: ¿A Mesa entende que, atendendo ao interesse da Nação e das nossas instituições, deve-se imprimir um rito tão célere quanto possível à tramitação da matéria, 400 respeitadas, é claro, todas as formalidades essenciaisc.

Assim foi dito, assim foi feito. O rito foi célere, como prometera S. Exa, mas as formalidades essenciais a que aludiu jamais foram respeitadas. Ao contrário, elas foram sabidamente atropeladas e notoriamente ignoradas em várias oportunidades. O Deputado Humberto Souto, Líder do Governo, levantou questão de ordem sobre 405 os procedimentos regimentais a serem observados, citando como fundamentos de suas dúvidas a manifestação de alguns dos mais eminentes juristas do País, entre os quais o Professor emérito Raul Machado Horta, o Professor Manoel Gonçalves Ferreira Filho, o Constitucionalista e ex-Ministro do STF Paulo Brossard, o inesquecível Mestre Seabra Fagundes, o ex-Ministro e Professor Célio Borja.

410 Com base nas opiniões desses preclaros doutrinadores, o Líder do Governo concluía que o processo: $1^{0}$ - só poderá ser iniciado após a prévia autorização da Câmara dos Deputados, por 2/3 de seus membros, conforme art. 51 , inciso I, da Constituição Federal; 20 - a referida autorização deve ser objeto de votação por escrutínio secreto, nos termos do art. 188, inciso II, do Regimento Interno da

415 Câmara; 30 - as normas procedimentais a observar para a referida autorização são as previstas no art. 217 do Regimento.

No mesmo sentido, manifestaram-se ainda os Deputados Roberto Jefferson e Gastoni Righi também em questões de ordem. A opinião dos juristas invocados era, portanto, incontroversa.

420 Mas de que valiam as opiniões desses mestres do Direito ante a decisão dos que de antemão me julgavam culpado? As questões de ordem foram contraditadas pelos Deputados José Genoíno e Nelson Jobim. Embora tenha o Presidente daquela Casa reconhecido que os argumentos levantados eram de grande relevância, ficou patente que, acima do bom senso, da isenção e da serenidade exigidos na direção

425 dos trabalhos, pairavam no ar a animosidade notória e a pressa inaudita de que estava tomada a maioria.

Depois de incluir na pauta da sessão do dia seguinte a constituição da Comissão Especial, o Presidente da Câmara advertiu desde logo que, se isso não se cumprisse, convocaria sessão extraordinária com esse fim, para a noite do dia 430 seguinte.

Sem que a ata registre qualquer manifestação do Plenário, anunciou S. Exa que, havendo apelo dos Líderes $\dot{c}$ sem constar nada em ata $\dot{c}$ a reunião seria antecipada para as dez horas da manhã, adiantando que, se a eleição não pudesse ser cumprida nesse horário, seria feita na sessão ordinária das 14 horas e, na hipótese de ainda assim não se consumar, seria convocada reunião noturna com esse propósito.

Não houve necessidade de se aguardar qualquer das sessões anunciadas para 
constituir a Comissão Especial, destinada a apreciar o pedido de impeachment entregue no dia $1^{\circ}$ de setembro. No dia imediato, o Diário da Câmara publicou a ata da reunião do Presidente com os Líderes Partidários, realizada nesse dia, às 18 horas e 10 minutos.

O Sr. Arthur Virgílio (PSDB ¿ AM) ¿ Permite-me um aparte, Senador Fernando Collor?

445 Ouço V. Exa.

O SR. FERNANDO COLLOR (Bloco/PTB ¿ AL) ¿ Pois não, Senador Arthur Virgílio.

O Sr. Arthur Virgílio (PSDB ¿ AM) ¿ Senador Fernando Collor, percebo que V. Exa, polêmico como é e tendo ressurgido na cena política como ressurgiu, talvez tenha colocado muitos Colegas nossos em dúvida: aparteio? Não aparteio? É bom para mim? Não é bom para mim? Eu, por outro lado, não saberia impor nenhum limite à 450 liberdade do meu mandato que não os limites da lei, da Constituição, do Regimento Interno da Casa, do decoro parlamentar. Gostaria, portanto, de dar meu depoimento de Líder do PSDB e de brasileiro que viveu os momentos descritos por V. Exa. E digo-Ihe que não vou entrar no mérito das acusações feitas ao Governo de $\mathrm{V}$. Exa . Reconheço que $\mathrm{V}$. Exa pagou um preço muito alto em um País onde 455 ninguém paga preço algum quase nunca, ou nunca! Eu poderia $\dot{c}$ e faço isso ¿ dizer que seu governo teve o mérito e o condão de revelar, pela vez primeira, preocupação com a inflação, uma tentativa que não deu certo, como outras não deram, mas o desejo de ver a economia estabilizada; abertura econômica; o projeto básico de reformas estruturais, depois intentado e levado parcialmente a

460 cabo por governos que sucederam V. Exa. Ouvi o discurso de V. Exa com bastante tranqüilidade, porque o meu Partido $\dot{c}$ e aqui faço justiça também àquele grande brasileiro chamado Ulysses Guimarães, do PMDB ¿ relutou ao ponto máximo diante da perspectiva do impeachment. Nem um historiador poderia dizer que o PSDB acolheu o impeachment, o PSDB quis lucrar com o impeachment. E Dr. Ulysses

465 Guimarães, V. Exa sabe disso, fez o impossível, do alto da sua sabedoria, para que soluções fossem encontradas fora do impeachment tão traumático, conforme sobre ele pontifica Paulo Brossard, no que muito bem relembrou aqui V. Exa. E não foi diferente o comportamento do PSDB nos episódios recentes envolvendo o Governo do Presidente Lula. Há pessoas que dizem que perdemos a eleição por isso. Eleição,

470 perde-se ou ganha-se; não existe a figura do empate. O PSDB tinha consciência clara de que não deveria mergulhar o Brasil na dúvida contra as instituições, no choque de ruas, até porque havia uma disposição muito clara de resistência por parte do Governo do Presidente Lula, quando acusado de fatos graves, gravíssimos, que são da memória de todos nós. O meu querido amigo e brasileiro admirável

475 Ministro Jarbas Passarinho ¿ Ministro da Justiça do seu Governo ¿́, relatou-me, e devo dar esse depoimento, que quando disse a V. Exa dos indícios das irregularidades na Legião Brasileira de Assistência (LBA), V. Exa teria dito a ele: ¿Ministro, mande investigari. E ele advertiu V. Exa da delicadeza do quadro até pessoal que envolvia pessoas próximas a V. Exa à época. E V. Exa disse: ¿Ministro,

480 eu já disse, mande investigari. Então o testemunho que eu queria dar é que $\mathrm{V}$. $E x^{a}$, primeiramente, não ofereceu a resistência que podia ter oferecido. Volto a dizer, não entro no mérito das acusações, jamais acusaria $V$. Exa, mas algumas delas me pareciam graves, em função dos fatos que chegaram ao meu conhecimento. $V$. Exa apenas $\dot{~ e ~ i s s o ~ e ́ ~ u m ~ m e ́ r i t o ~ s i m ~ ¿ ~ n a ̃ o ~ r e s i s t i u, ~ c o m o ~ p o d e r i a ~}$

485 ter resistido, dentro dos poderes que este nosso presidencialismo torto propicia aos Presidentes da República. Nós vimos depois. Se V. Exa tivesse tido, por exemplo, uma relação mais ¿abertac com certos setores do Congresso, talvez tivesse concluído o seu mandato. Se V. Exa tivesse, na verdade $\dot{c}$ e vou usar uma expressão que foi, corriqueiramente, banalizada $\dot{\iota}$, relações menos republicanas 490 com certo segmento do Congresso, V. Exa teria, certamente, ido até o fim do seu mandato. Vou aqui secundar o Presidente Lula ¿ não sou eu que estou inovando, não estou inventando nada; aliás, tenho uma frustração na minha vida de não ser capaz de inventar nada; tudo que eu digo alguém já disse, tudo que eu faço 
alguém já fez $\dot{c}$, que disse que $V$. Exa estava anistiado, seja pela justiça ¿ e aí leiase também o preço pessoal, familiar, psicológico que $V$. Exa pagou $\dot{c}$, seja pela manifestação do povo das Alagoas Essa foi a expressão do Presidente Lula. Eu, então, vejo V. Ex ${ }^{a}$ como um Senador, como os demais. Daí eu querer, neste momento, ter tido a honra de ter sido o primeiro a aparteá-lo num discurso que, na Câmara, chamaríamos de Grande Expediente. Aparteá-lo para dizer que aqui teremos momentos de

500 concordâncias, de discordância. Vou concordar com V. Ex a ou discordar de V. Ex sem nenhum preconceito; vou concordar ou discordar de V. Ex ${ }^{a}$ com mais ou menos intensidade, a depender do fato em si, sem ter qualquer sensação de que V. Exa deveria ser alguém estigmatizado. Em outras palavras, de maneira muito limpa e muito clara, eu olho para aqueles episódios com muita curiosidade. A pergunta que eu me faço hoje é,

505 se V. Ex a tivesse dado tudo o que pudesse para se manter no poder, se não se teria mantido no poder; se tivesse retalhado o seu governo... Eu vi V. Ex ${ }^{\mathrm{a}}$ praticar, do ponto de vista econômico, um suicídio, praticar uma política econômica que julgava equivocada, inflação de $26 \%$ ao mês, e V. Ex a persistindo na política econômica quando era muito fácil ter aberto as comportas do populismo econômico, deixava pura e

510 simplesmente a inflação galopar, daria à sociedade aquela sensação de alívio imediato que a irresponsabilidade fiscal e monetária dá. A outra fórmula mágica, velha, superada, que é detestável, teria sido retalhar o governo, dividi-lo pelos partidos. Eu sempre entendo que coalizão é necessária e que é bom se ter maioria. Quando Allende morreu, não me lembro de quase nada do que falaram sobre ele, eram sempre aquelas coisas do

515 tipo ¿grande homem $\underset{\iota}{ }$, grande isso, grande aquilo. Essas coisas que ficam, que todo mundo diz de todo mundo quando alguém ilustre morre.

Mas Enrico Berlinguer, Secretário do Partido Comunista Italiano ¿ hoje Partito

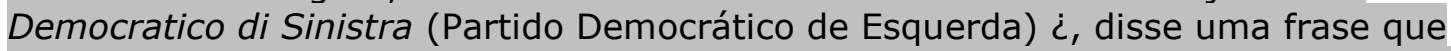
foi a única que guardei de todas as que li sobre Allende. Ele disse: ¿Maioria escassa

520 não valeć. Então, qual é a razão que me leva a redobrar a vigilância em relação ao Governo que aqui está? Sou Líder de um Partido de oposição ao Governo que aqui está. É que vejo uma movimentação terrível: são quatrocentos Deputados, trezentos e cinqüenta Deputados, em torno de quê? Qual é o projeto? Qual é a emenda constitucional que está em voga? Impedir a CPI não impede, até porque há

525 uma que acabou de ser aprovada pela Minoria, por mais de um terço dos Deputados da Câmara. Se não existe um projeto, trazem-se para o redil do Governo Deputados, e Deputados a granel, e é de se imaginar que, mais hora menos hora, possamos ver a repetição daqueles fatos lamentáveis de pouco tempo atrás. Mas, se existe um projeto, qual é o projeto? Tocar para frente as reformas

530 estruturais que V. Exa propôs no seu Governo e não conseguiu executar? Depois o Governo do Presidente Itamar Franco fez outra parte, o Presidente Fernando Henrique fez outra parte, e o Presidente Lula fez outra parte em seu primeiro mandato. Se existe um projeto, uma proposta, aí, então, justifica-se a preocupação com um número tão avassalador de Deputados. Aqui, no Senado, o Governo

535 passou a Legislatura passada toda em minoria, e não deixou de ser aprovada nenhuma matéria que fosse de interesse público. Andamos na vanguarda do Congresso o tempo inteiro. Talvez, sejamos, hoje, uma Minoria apertada. Fomos uma Maioria apertada. É essencial para o funcionamento do Congresso que haja concordância ¿ isso também recebe a colaboração do espírito democrático do

540 Presidente Renan Calheiros $\dot{~}$, mas é essencial para o funcionamento do Congresso que a Oposição aqui se ponha de acordo com as votações, porque há número bastante para praticamente paralisar o Congresso Nacional! A Oposição não usou e não usa desse instrumento, porque não quer paralisar o País, pois sabe que paralisar o Congresso, paralisar o Senado significa paralisar o País. Então, não há 545 necessidade nenhuma disso. Sempre digo que é tão mais fácil lidar conosco e dizer: ¿O projeto é este, vamos votari. O voto é gratuito, não há o que discutir. Não tem 
de ficar inventando moda, enfim! Então, Senador Fernando Collor, eu não poderia dar-Ihe um aparte de reprovação, nem estou aqui para dar-Ihe um aparte de apoio. Estou aqui para dizer que recebo V. Exa, em nome do PSDB ¿ V. Exa é bem-vindo à

550 Casa $\dot{c}$, para ser um Senador como nós, e para revelar de público minha inquietação. Minha pergunta é: e se $\mathrm{V}$. Exa tivesse tido com o Congresso outra relação, uma relação mais aberta? Há pessoas que usam eufemismos. A bajulação é uma instituição nacional. V. Exa deve ter sido muito bajulado. Há bajuladores de vários tipos. Então, todo homem que chega à Presidência da República fica sedutor

555 de uma hora para outra. Sou amigo do Presidente Fernando Henrique há muitos anos e nunca ouvi dizer que ele era sedutor, mas ele ficou sedutor quando chegou ao poder. O Presidente Itamar ficou sedutor. O Presidente Lula é o mais sedutor de todos, até o final do mandato dele. $V$. Exa deve ter sido muito sedutor até aquela altura. Assim era também Artur Bernardes; Washington Luiz, sem dúvida alguma; e 560 Getúlio Vargas ¿ deste, nem se fala, até porque este o era mesmo. Eu gostaria de dizer a V. Exa que, assim como há a instituição da bajulação, temos um certo poder que as pessoas dizem que se trata do calor: ¿O Governo tem de ser mais caloroso, o Governo tem de ser mais carinhosoc. Custo a entender como se traduz em carinho uma ação de governo. O que é carinho? É o Presidente da República, tenha

565 ele o nome que tiver, fazer cafuné no Deputado e no Senador? Não julgo que isso seja próprio, nem republicano, nem adequado. Fazer cafuné, não! Isso é coisa de namorado. Não é para se fazer cafuné! O que é carinho? Carinho é o que se deu nos escândalos recentes? O que é carinho, enfim? Portanto, creio que V. Exa, hoje, deu importante contribuição. Dizia o Senador Antero Paes de Barros a um

570 estudante de Direito: ¿Não precisa ser não-formado, mas alguém que estude e cultue o estudo do Direitoc. Esse não é meu caso, embora eu seja bacharel em Direito. É uma grande contribuição! Esse é um discurso que foi recebido com muita ansiedade, que não decepcionou e que marca seu ingresso, no seu estilo, como Senador pleno, com assento nesta Casa, representando seu Estado, Estado muito

575 afortunado, que, pela segunda vez, elege um Presidente do Congresso e que teve a honra de ter tido, apesar da sua escassa representatividade eleitoral, três Presidentes da República: Deodoro, Floriano e V. Exa. Portanto, seja bem-vindo à Casa! Vamos, pura e simplesmente, sem mais prolegômenos, colocar-nos sempre à disposição do debate e da conversa não-preconceituosa. E volto a dizer: V. Exa é

580 um Senador pleno com assento nesta Casa, representando o bravo povo das Alagoas. Muito obrigado, Senador.

O Sr. Epitácio Cafeteira (Bloco/PTB ¿ MA) ¿ Senador Fernando Collor, V. Exa me permite um aparte?

O SR. FERNANDO COLLOR (Bloco/PTB $\dot{A} \mathrm{AL}$ ) ¿ Muito obrigado.

585 Concedo um aparte ao Senador Romeu Tuma e, em seguida, ao Líder do PTB, Senador Epitácio Cafeteira, não sem antes dizer algumas palavras a respeito do que afirmou aqui o Senador Arthur Virgílio.

Um dos grandes equívocos que, sem dúvida, cometi como Presidente da República $¿$ e isso está dito em algum momento em meu pronunciamento ¿ foi o de ter tido

590 com o Congresso Nacional uma relação não adequada. Digo que tive uma relação não adequada, porque dediquei $80 \%$ do meu tempo à administração. $E$, nesse regime presidencialista, que entendo ser caduco, obsoleto e anacrônico, o Presidente da República é o Líder político da Nação e tem de fazer política, sobretudo. Em relação ao Congresso, acredito que o que queremos, o que desejamos é consideração.

Há uma passagem ocorrida nos anos 50 quando o então Senador Juracy Magalhães ¿ não sei se ele estava no exercício do mandato ¿ era candidato ao Governo da Bahia. Era o último comício, com a praça cheia. Ele termina seu discurso e desce do palanque. É aquela cena que todos conhecemos, quando descemos a escada: a

600 população acorre, e todo mundo quer apertar a mão do candidato, abraçá-lo. Todos já experimentamos isso ¿ nós o experimentamos cotidianamente. Nesse momento, o Senador Juracy sentiu o braço direito dele preso por alguém que o segurava 
fortemente. Ele queria levantar o braço para cumprimentar as pessoas, para acenar e não conseguia. Nisso, ele viu que quem o segurava era um senhor. Pegou, então, um trocado e colocou-o na mão do senhor, pensando: ¿Bom, com isso, ele vai me deixar com o braço libertoi. Mas o senhor continuou agarrado no braço dele. Ele se vira para o senhor e diz: ¿Mas, meu amigo, eu já não lhe dei um dinheirinho? 0 que você quer mais? ¿. Ele respondeu: ¿Ah, Dr. Juracy, eu quero consideração¿. $\mathrm{Na}$ realidade, o que ele queria era que o Juracy olhasse para ele, perguntasse algo,

610 manifestasse alguma atenção.

É exatamente isto o que penso: dentro desse sistema presidencialista que aí está, inteiramente obsoleto ¿ data venia opinião em contrário $\dot{c}$, é preciso que o Presidente da República esteja absolutamente afinado com o Congresso.

615 bastar.

O SR. FERNANDO COLLOR (Bloco/PTB ¿ AL) ¿ Bom, esse é outro ponto, mas acredito $\dot{i}$ e o tiro por mim, por $V$. Exa e por todos os outros, posso assim dizer $\dot{ }$ que o que desejamos do Presidente da República é a consideração de um telefonema, mesmo para alguém da Oposição: ¿Ouvi seu pronunciamento, ouvi sua

620 crítica. Obrigado por ter me alertado para issoc. É preciso que ligue para alguém da sua base e diga: ¿Obrigado pela defesa que fez do meu Governo. Eu gostaria de reunir vocês para explicar qual é meu programa de Governo, qual é a idéia que tenho a respeito desse ou daquele projetoc. Isso é consideração. Creio que é isso o que cativa. Quando se procede de maneira diferente, é porque não está havendo

625 paciência suficiente para se ter essa consideração.

Concedo um aparte, por favor, ao Senador Romeu Tuma. Em seguida, eu o concederei ao Senador Epitácio Cafeteira.

O Sr. Tasso Jereissati (PSDB ¿ CE) ¿ Senador Fernando Collor, apenas quero alertá-lo de que eu também gostaria de fazer um aparte.

630 O SR. FERNANDO COLLOR (Bloco/PTB ¿ AL) ¿ Pois não, Senador Tasso. O Sr. Tasso Jereissati (PSDB ¿ CE) ¿ Obrigado.

O Sr. Aloizio Mercadante (Bloco/PT ¿ SP) ¿ Peço-lhe que também me conceda um aparte depois.

O Sr. Romeu Tuma (PFL ¿ SP) ¿ Senador Collor, eu pediria desculpas por

635 interromper seu pronunciamento, porque $\mathrm{V}$. Exa está fazendo um discurso histórico que revela as páginas contemporâneas de um período difícil e amargo pelo qual V. Exa passou, assim como a Nação e todos aqueles que, por sua deferência, puderam trabalhar ao seu lado. Recebi, agora, um telefonema da minha esposa, Zilda, que me disse: ¿Você tem de falar alguma coisa. O Presidente Collor foi tão elegante ao

640 descrever seu comportamento ético e moral na direção da Polícia Federal naquele período, que você não pode ficar em silêncioc. Realmente, quando me convidou, V. Exa o fez baseado no princípio, Senador Collor, de que eu tinha um comportamento ético, correto e respeitoso a todo o ordenamento jurídico da Nação. Aceitei o convite, o que foi uma honra para mim. V. Exa tomou uma iniciativa audaz, ao me

645 fazer acumular dois cargos. Assumi a Secretaria da Receita Federal, surpreendendo a Nação. Tornei-me uma pessoa com um poder que poderia ser inigualável, mas soube, seguindo o direcionamento e as ordens de V. Exa, comportar-me com ética e com respeito ao cidadão, sem nunca abusar da força que $V$. Exa tinha me proporcionado ao assumir os dois cargos. V. Exa foi correto na exposição que fez,

650 quando se referiu à atuação isenta da Polícia. O Senador Arthur apresentou uma questão ¿ que, acredito, não caberia no discurso de V. Exa ¿ sobre a LBA. Recebi um telefonema do então General Agenor, Chefe da Casa Militar, dizendo que V. Exa queria que o juiz decretasse a prisão preventiva dos acusados. E eu disse: ¿É difícil, porque ainda não temos os dados concretos; o processo está sob investigaçãoc.

655 Procurei o juiz, que tentava, de alguma forma, uma solução com o Superintendente da Polícia Federal de São Paulo. Mas não alcançávamos o objetivo, porque faltavam dados que a investigação poderia oferecer no futuro. Também depus na Justiça, Senador $\dot{c}$ não foi só aqui $\dot{c}$, como testemunha de que, em nenhum momento, $V$. 

contrário aos interesses de V. Exa. Não. V. Exa queria que a apuração fosse feita com isenção, com clareza e com objetividade, para que se chegasse à conclusão correta dentro da lei vigente. Há outro fato que trago guardado no coração há 15 anos. Nem sei se eu teria coragem de mencioná-lo hoje, mas temos obrigação com a Nação, e V. Exa está cumprindo com sua obrigação, relatando os fatos. Durante o período do processo de impeachment, entrando no Palácio, encontrei um Ministro das Forças Armadas. Um deles ¿ havia três; não havia o Ministério da Defesa $\dot{\text {, }}$ meu amigo, respeitoso, um homem amante da democracia e do País, achava que estava havendo muita injustiça. Não estou entrando no mérito, apenas relatando 670 um fato, Sr. Presidente. Ele, então, propôs a V. Exa medidas radicais, para que se evitassem certas injustiças que, de acordo com o conhecimento dele, eram praticadas contra V. Exa. E disse-me ele: ¿Não consegui convencer o Presidente. Ele se recusou a issoc. Esse é um fato. Não sei se se é democrata quando se diz ser ou se o reconhecimento dessa característica é dado àquele que toma atitudes

675 democratas. Não tenho razão para duvidar do que me falou o então militar, mas não sei se essa revelação pode ter trazido alguma amargura a V. Exa. Mas esse fato é algo que está dentro do meu coração, da minha alma. Eu poderia perguntar-lhe isso particularmente, mas preferi falar à Nação. Muito obrigado.

O SR. FERNANDO COLLOR (Bloco/PTB ¿ AL) ¿ Muito obrigado, Senador Romeu

680 Tuma. V. Exa sabe da admiração e do respeito que por $V$. Exa nutrimos, não somente eu, mas todos os seus Pares nesta Casa, bem como o Estado de São Paulo e a população brasileira. V. Exa foi um dos mais corretos, leais e abnegados servidores públicos que a Polícia Federal conheceu e com quem tive o privilégio de conviver quando fui Presidente da República. Muito obrigado, mais uma vez, pela

685 correção com que V. Exa sempre se houve no exercício das suas atribuições, Senador Romeu Tuma. Agora, sinto-me particularmente homenageado de poder fazer parte de um Colegiado em que V. Exa tem assento, representando, com brilhantismo, o Estado de São Paulo. Muito obrigado.

Ouço o aparte do Senador Epitácio Cafeteira, Líder do PTB nesta Casa.

690 O Sr. Epitácio Cafeteira (Bloco/PTB ¿ MA) ¿ Nobre Senador e ex-Presidente da República Fernando Collor, vivi muito durante todo o meu trajeto, mas há coisas de que não nos esquecemos. Lembro-me de que, em uma das camisetas que $V$. Exa usava para fazer cooper, estava escrito que ¿̇o tempo é o senhor da razãoc. Isso é absolutamente certo. V. Exa esperou. Primeiramente, foi julgado e inocentado pelo

695 Supremo. Continuou sua luta. Agora, o povo das Alagoas Ihe dá o mais alto cargo do Legislativo brasileiro: Senador pelas Alagoas. Congratulo-me com V. Exa, exatamente, pela obstinação, no sentido de usar a tribuna do Senado, nesta Casa, em que o mandato de $V$. Exa foi cassado, para, também daqui, ter a oportunidade de levar ao Brasil toda a história da cassação de seu mandato. Repito: congratulo-

700 me, portanto, com V. Exa. Sou um homem feliz, porque tenho a oportunidade de ser o Líder de um ex-Presidente que nunca se esqueceu de dar ao povo a demonstração do que foi seu Governo e da injustiça que sofreu.

O SR. FERNANDO COLLOR (Bloco/PTB ¿ AL) ¿ Muito obrigado, Senador Epitácio Cafeteira, Líder do nosso Partido Trabalhista Brasileiro. Fomos companheiros,

705 Governadores de Estado, e, desde aquela época, sempre nutri grande simpatia por $\checkmark$. Exa, pelo seu espírito aberto e democrata e, sobretudo, pela seriedade com que sempre soube conduzir os negócios do Estado e com que tão bem soube exercer os mandatos legislativos que Ihe foram conferidos.

Hoje, como decano desta Casa $\dot{c}$ eleito pelo seu Estado com um percentual de votos

710 extraordinário, praticamente sem fazer campanha $\dot{c}, \mathrm{~V}$. Exa é também muito homenageado, não somente pelo seu povo, que Ihe quer e que o admira, mas também por todos nós, Senadores, que temos por $V$. Exa muito respeito e afeição. Obrigado pelas suas palavras.

Concedo um aparte ao Senador Tasso Jereissati. 
715 O Sr. Tasso Jereissati (PSDB ¿ CE) ¿ Senador Fernando Collor, permita, ao comentar o discurso que $\mathrm{V}$. Exa aqui fez, que eu me manifeste com toda a sinceridade. Primeiramente, quero dizer que, à época do seu impeachment ¿ hoje V. Exa trouxe à tona a sua visão de como o processo aconteceu $\dot{c}$, eu era presidente do PSDB, como hoje ainda o sou. Não era Parlamentar, mas era, àquela

720 altura, presidente do PSDB. Por essa razão, acompanhei todo o processo que se desenvolvia $\dot{i}$ vendo-o de fora $¿$ no Congresso Nacional e perante a opinião pública. Inclusive tive a oportunidade de conversar com V. Exa sobre a crise que envolvia o Brasil em alguns momentos. Hoje, quero fazer uma constatação $\dot{c}$ acho até que não é o momento adequado para colocar em julgamento o mérito das questões, até

725 porque $V$. Exa vive um novo momento ¿ por haver vivido os dois momentos como presidente do PSDB. Repito: sem fazer qualquer julgamento de mérito, nem em nenhum momento apresentar qualquer sentimento de arrependimento pela forma como o PSDB se conduziu naquele momento $\dot{i}$ isso pode até ser revisto um dia. Quero fazer uma constatação inevitável: sem dúvida alguma, o comportamento da

730 classe política brasileira, da sociedade brasileira como um todo, principalmente das chamadas elites brasileiras, mudou radicalmente em relação a denúncias quando feitas no seu Governo e quando feitas recentemente. Novamente, repito: não estou fazendo qualquer julgamento de mérito nem daquela época, nem da de agora. Apenas faço uma constatação de quem viveu esses dois momentos como

735 presidente de Partido. Denúncias que me pareceram graves à época foram vistas com absoluto rigor, e, como V. Exa disse aqui, em determinados momentos, com tamanho rigor que, inclusive, atropelaram formalidades legais. Vivi, agora, momentos em que denúncias também foram feitas ¿ novamente, não estou julgando se com fundamento ou não $\dot{c}$, e com absoluta tolerância por parte da 740 chamada elite brasileira, a elite intelectual. Lembro-me de que alguns artistas, algumas pessoas públicas que, em determinados momentos, ousaram ter posições favoráveis a V. Exa quando Presidente da República foram praticamente queimadas diante da opinião pública. Hoje, não; hoje, vejo declarações de grandes artistas dizendo que ¿iisso faz parte da políticać, ¿isso é assim mesmo ¿, ou seja, dando um

745 enfoque completamente diferente do daquela época. Não sei se o Brasil mudou, para melhor ou para pior ¿ também não é o momento de discutirmos isso ¿̇, não sei se o Brasil evoluiu ou involuiu; não sei se era preconceito, pelo fato de V. Exa, apesar de ser um homem nascido de família abastada, ter vindo de fora do establishment de poder tradicional do País; não sei se por causa da região, ou se

750 foi, realmente, uma grande evolução que houve neste País, mas foi diferente. Creio que um dia a História vai estudar isso melhor. O importante é que $\dot{c}$ a meu ver $\dot{ }$ não vale discutir o mérito neste momento, porque $V$. Exa pagou um preço muito alto diante de todas essas circunstâncias. Talvez V. Exa tenha sido o homem público da História recente do País que pagou o mais alto preço por eventuais erros

755 cometidos $\dot{c}$ se é que os cometeu. E, já havendo pago muito caro por isso, foi $\dot{~ n a ̃ o ~}$ sei se a palavra é canistiadoc, porque não cabe ¿trazido de volta à vida pública pelo voto do povo de Alagoas. De nossa parte, como democratas que somos, julgamos isso mais do que suficiente para o considerarmos um homem de grande experiência política, perfeitamente reintegrado à vida política brasileira. A experiência, vivência

760 e até os sofrimentos pelos quais V. Exa passou serão muito importantes para que esta Casa possa atingir um alto nível, adequado àquilo que o Brasil espera de todos nós. Mais do que a experiência e a vivência, talvez o próprio sofrimento seja o que V. Exa vai trazer de mais importante para todos nós, Senadores, dentro deste seu novo momento político. E eu gostaria de, também em nome do PSDB, dar-lhe as

765 boas-vindas não só a esta Casa, mas à vida política brasileira.

O SR. FERNANDO COLLOR (Bloco/PTB ¿ AL) ¿ Muito obrigado, Senador Tasso Jereissati, pelas palavras tão generosas. V. Exa, além de companheiro de geração, participou de momentos cruciais da vida política deste País em relação ao meu período como Presidente. Em duas oportunidades, estivemos muito próximos de ter um entendimento que viabilizasse a governabilidade do meu período como 
Presidente e que, infelizmente, por motivos que não nos cabe agora discutir, não foi possível. Mas eu teria tido muito prazer e muita honra se todos aqueles entendimentos entabulados com o então Presidente Franco Montoro tivessem dado certo. Talvez a história fosse outra. Talvez os rumos da minha administração

775 fossem tomados de uma forma mais adequada ao momento, de forma, sobretudo, a me precaver contra os equívocos que cometi quando Presidente da República, sobretudo na minha relação com a classe política.

Muito obrigado a V. Exa pelas palavras.

Continuando, Sr. Presidente...

780 O Sr. Aloizio Mercadante (Bloco/PT ¿ SP) ¿ Presidente Collor, V. Exa me concede um aparte?

O SR. FERNANDO COLLOR (Bloco/PTB ¿ AL) ¿ Pois não. Ouço o aparte do

Senador Aloizio Mercadante, e, em seguida, do Senador Mão Santa.

O Sr. Aloizio Mercadante (Bloco/PT ¿ SP) ¿ Presidente Collor, eu não poderia me

785 omitir neste momento. De um lado, para deixar explícito o que eu lhe disse desde o primeiro dia em que V. Exa chegou a este plenário. Eu o considero um Senador como todos os demais, que construiu seu mandato pela urna, pelo voto do povo de Alagoas, e será tratado, nessa condição, com o mesmo respeito e a mesma consideração, sem qualquer tipo de revanchismo ou de tratamento que não seja o

790 reconhecimento da vontade legítima e democrática do povo de Alagoas. Nossa relação, nos dias iniciais desta Legislatura, tem sido respeitosa, cordial e construtiva. Mas, quando fazemos o balanço da história, é evidente que temos posições diferentes. É muito oportuno o pronunciamento de V. Exa. Oportuno que suba à tribuna e defenda sua visão, suas convicções, seu mandato, e que faça as

795 advertências para a sociedade brasileira a respeito de toda a experiência traumática, dolorosa e, ao mesmo tempo, rica, que atravessamos naqueles dias turbulentos, que vivi com muita intensidade. Eu estava do outro lado. Percorri o Brasil acreditando em um outro projeto. Também éramos um pequeno Partido, com apenas sete Deputados Federais. Foi uma disputa duríssima. Às vezes, penso que

800 houve excessos desnecessários na disputa eleitoral, que deixaram marcas para o futuro. Mas foi uma disputa que $V$. Exa venceu, e consideramos e reconhecemos a vitória. No início do mandato, apesar de muitas divergências ¿ é inegável que as dificuldades eram imensas, a margem de manobra muito pequena, e não havia muito espaço para a política econômica de um novo governo ¿̇, $v$. Exa tratou de 805 temas difíceis. Em um balanço, depois de tanto tempo, eu diria que algumas coisas foram importantes para a construção futura da História do Brasil. Mas eu estava do outro lado. Não compartilho com aqueles que consideram que o trabalho da CPI ou o impeachment se deveram à falta de uma relação republicana entre o governo e o Congresso. Eu estava na dimensão republicana do meu mandato, daquilo que eu

810 pensava que era o meu mandato. E, naquela CPI, com pessoas como Mário Covas, Pedro Simon, Maurício Corrêa, o Senador José Paulo Bisol e Jackson Pereira, que também não está mais aqui $¿$ era um Deputado do PSDB e estava comigo naquele trabalho $\dot{c}$, uma parte representativa daquele esforço não era de homens públicos que alterariam a sua atitude em função de qualquer outro tipo de negociação que

815 não fosse a apuração dos fatos, a busca da verdade, da transparência, a investigação de graves denúncias que haviam sido apresentadas. Excessos, seguramente, ocorreram. Mas eu digo, com a mesma franqueza que V. Exa apresentou hoje aqui, que fiz e participei daquela CPI com a mesma convicção que, tenho certeza, Pedro Simon, Eduardo Suplicy, Mário Covas e outros participaram.

820 Eu entendia que estava contribuindo para a transparência, para a ética na política, para a mudança, para o aperfeiçoamento das instituições democráticas do Brasil. Fui Líder de um Governo que viveu acusações graves, como foram mencionadas aqui. Sou militante de um partido que sofreu acusações e denúncias graves, que todos aqui acompanharam. Mas esse sentimento de apurar as coisas, de exigir a verdade, de exigir a transparência é uma virtude democrática que tem que ser preservada e valorizada. A maturidade democrática vai permitir que o Brasil saiba 
corrigir as injustiças, que não cometa, eu diria, o açodamento, às vezes, de um denuncismo que pouco constrói. Mas, ao mesmo tempo, não podemos olhar para a História sem considerar que os erros têm de ser identificados, apurados e punidos com rigor. V. Exa pagou um preço muito alto e reconstruiu sua vida na disputa democrática, mas, assim como V. Exa tem a convicção do mandato que construiu, eu tenho orgulho de ter participado daquela CPI, de ter lutado pelo que lutei. E deixo claro que, se alguns mudaram de posição ou de lado na véspera do impeachment pelo calor da opinião pública, outros não o fizeram por isso, mas pela verdadeira convicção democrática de que havia equívocos gravíssimos no governo e que aquilo não podia continuar. Espero que na convivência prolongada que teremos possamos aprofundar esta conversa e esclarecer episódios. Tenho todo interesse em conhecer talvez uma dimensão que nem foi possível conhecer. Mas eu não seria sincero, não seria verdadeiro, não seria franco, não seria correto comigo e com companheiros que não estão aqui hoje para se posicionar se não dissesse isso com todo o respeito a V. Exa. Fiz o que a minha consciência e o meu mandato julgavam que devia ser feito. Muito obrigado.

O SR. FERNANDO COLLOR (Bloco/PTB ¿ AL) ¿ Senador Aloizio Mercadante, eu não tenho dúvida nenhuma de que dentre aqueles que participaram das diversas 845 etapas do processo de impeachment havia pessoas que, como V. Exa, agiram única e exclusivamente com base em seu convencimento, sem qualquer outro tipo de interesse, sem qualquer outra vontade que não a de sinceramente apurar os fatos, tomar sua posição e chegar à sua conclusão. Mas, sem dúvida nenhuma, V. Exa dever ter à época percebido $¿$ e aqui, no resto do meu discurso, alguns fatos eu 850 poderei relatar $\dot{~ q u e ~ n a ̃ o ~ f o r a m ~ s o m e n t e ~ a t r o p e l o s ~ d a s ~ n o r m a s ~ j u r i ́ d i c a s . ~ O ~ q u e ~}$ houve foi uma violação, uma violência cometida contra o Estado de Direito Democrático. Eu não me insurgi em nenhum momento a que a CPI fosse instaurada. Em nenhum momento. V. Exa sabe, como também os Srs. Senadores, que o Presidente da República, no exercício das suas funções, caso não deseje que uma CPI se instale, ele pode até não conseguir, mas ele tem mecanismos para colocar em ação para evitar a instalação da CPI. Eu, ao contrário, disse: ¿Faça-se a CPI i. Ao contrário, eu disse: ¿Investigue-se tudoc. V. Exa sabe que eu poderia muito bem chegar até a Receita Federal e dizer: ¿Isso aqui é uma perseguição, é uma ação deletéria, o Governo não vai fornecer qualquer tipo de informação para

860 que essa CPI se transforme em um cavalo-de-batalha contra o Governoc. V. Exa era muito próximo, talvez não da segunda equipe, mas da primeira equipe do governo, e sabia muito bem o que nos inspirava e o que nos animava naquele momento. Éramos um grupo de jovens idealistas que pretendia mudar o Brasil. Acreditávamos que essa mudança poderia ser rápida, poderia ser eficiente. Bastava 865 o nosso desejo, o nosso idealismo e os votos que havíamos recebido, depois de quase trinta anos sem que o povo pudesse escolher seu Presidente pelo voto popular, para que isso fosse possível. Mas acolho, com satisfação, seu aparte, nobre Senador Aloizio Mercadante.

Ouço V. Exa, Senador Mão Santa.

870 O Sr. Mão Santa (PMDB ¿ PI) ¿ Presidente Collor, Shakespeare disse que não há bem nem mal: o que vale é a interpretação. Vou dar minha interpretação, contrariando os que viveram no Congresso. Eu era Prefeito. Deus me permitiu governar a minha cidade e o Estado do Piauí com o Presidente Sarney, com V. Exa, Presidente Collor, com Itamar e com Fernando Henrique Cardoso. V. Exa foi um 875 extraordinário Presidente da República! Presidente Renan, trabalhei por esse Collor mais do que pelas minhas eleições. E sabe por quê, Renan? Por medo! Tenho de confessar. Juscelino disse: ¿eu tenho medo de ter medoc. Mas a gente tem. Sabe como? Eu era Prefeito da cidade de Parnaíba. Atentai bem! Ficava apavorado! Todas as Prefeituras estavam sendo invadidas. Estávamos vivendo um clima $¿$ e 880 acho que Deus escreve certo por linhas tortas $\dot{c}$, e o Presidente Lula da Silva era o líder, de invasões. Em Parnaíba, não! Não por minha autoridade, mas porque lá tem a Capitania dos Portos ¿ vínhamos do regime militar $\dot{c}$, tem tiro-de-guerra, 
polícia. Mas todas, pelo Brasil afora, ele invadiu. Então, falei para o meu secretário: vamos trabalhar para esse homem, porque assim a gente vai já ser invadido; esse Collor tem de ganhar! V. Exa irradiou uma autoridade tão grande que, de repente, no País ¿ porque estavam aí os comandos grevistas ¿ leu-se novamente na bandeira ¿Ordem e Progresso¿. Essa é a verdade, aquilo que todo mundo viu. Errar é humano. Acho que o Congresso errou. Vi a cassação de V. Exa, assisti a ela toda. Nesse dia, Presidente Renan Calheiros, encontramos... Até antes, lá nas praias do

890 Piauí. E não fui à Prefeitura. Sentei-me no chão e fiquei assistindo pela televisão. E vi um que passou para nos inspirar, para nos guiar: Luís Eduardo Magalhães. Ele era filho de Antonio Carlos Magalhães, mas a grandeza dele foi vista naquele dia. Assisti a todos os pronunciamentos, pude ver a diversidade. E é Luís Eduardo Magalhães que respeitamos, é dele que nos orgulhamos. Ele ficou ali, advertindo o erro. Então, acho que aceitamos. Quem não aceitou o julgamento de Cristo? O que podemos fazer? Quem não aceitou o julgamento de Sócrates? Queimaram Joana DiArc. Mas V. Exa está aí. Além daquilo que vemos, a história da carroça, a sua visão, a globalização, a abertura, vou dizer-Ihe: lá na minha cidade, havia um hospital inacabado, cujo nome coloquei o do Senador que tombou aqui, Dirceu

900 Arcoverde, porque era da Fundação de Saúde Waldir Arcoverde, do seu Governo, e era Ministro aquele extraordinário homem, Alceni Guerra. E não é isso: de repente $¿$ é verdade $¿$ creches.

Arthur Virgílio, onde está o Mercadante? Não há creche. Olha, era só Adalgisa ver um menino na rua, que fazia uma creche. V. Exa e a LBA ¿ não vou entrar em

905 detalhes $\dot{~ t i v e r a m ~ u m ~ l a d o ~ m u i t o ~ b o m, ~ p o r q u e ~ n a ̃ o ~ f i c a v a ~ c r i a n c ̧ a ~ d e s a m p a r a d a ~ n o ~}$ seu Governo. Tanto é verdade, que, ao sair dali e voltar para meu consultório, ganhei uma eleição para Governador, o que ninguém acreditava. Fui Prefeito, quando V. Exa era Presidente da República. Presidente Renan Calheiros, aqui estiveram João Calmon, Darcy Ribeiro, Cristovam Buarque: é a educação, a

910 capacidade. Ninguém fez mais do que V. Exa. Aqueles Caics eu inaugurei em Parnaíba. E mais, fui Governador dois anos depois, e dezenas de Caics estavam lá e continuaram; consegui colocá-los para funcionar. Não existem, nos 507 anos de Brasil, estruturas tão dedicadas à educação como os Caics de V. Exa. Arrependido pode estar o Congresso. Sei Psicologia mais do que os que falaram, porque sou

915 médico; não adianta, sempre vão buscar uma justificativa. Mas não estou arrependido; nós votamos em V. Exa. Presidente Collor, no nosso Nordeste, aprendemos aquilo que se diz: ¿a vida é um combate que aos fracos abate e aos fortes, aos bravos só pode exaltar. ¿ V. Exa é esse forte e bravo. Mas terminaria com o que vemos nas músicas, porque a música fala muito mais do que discurso e

920 palavra. Estão aí os salmos: ¿O Senhor é meu pastor, e nada me faltarác. É uma música de Davi. Então, a música do Brasil diz que ninguém se perde no caminho de volta. V. Exa está aí e é um orgulho da democracia, do Nordeste, do nosso País. O SR. FERNANDO COLLOR (Bloco/PTB ¿ AL) ¿ Muito obrigado, Senador Mão Santa. V. Exa sempre me cumula com muita atenção, com muita generosidade nas 925 palavras que profere. E, com sua autenticidade e sabedoria, expressa-se de uma maneira que o nosso povo compreende, entende e gosta. V. Exa disse bem. Na votação do pedido do meu impeachment pela Câmara dos Deputados, vários e bravos companheiros também demonstraram a absoluta conviç̧ão, a absoluta certeza de que o que estava se desenrolando era algo que

930 visava, única e exclusivamente, a retirar da Presidência alguém que havia sido para ela legitimamente eleito, entre eles, o saudoso Luís Eduardo Magalhães e, aqui presente, o Deputado Roberto Jefferson, que, até o último instante, ficou ao nosso lado.

Foram 36 Deputados que votaram contra o impeachment. E alguns de V. Exas

935 devem lembrar-se de cenas: ¿Pela minha mãe, pelos meus filhos, voto ¿sim ¿ pelo impeachment. $\dot{V}$. Exas devem até ter se sentido incomodados com certos tipos de voto, porque não foram votos dados pela convicção, pela certeza formada, mas por outros interesses que estavam minando as bases dos princípios republicanos 
naquela Casa do Congresso.

940 Com a permissão de V. Exas, continuo.

Não houve, então, necessidade de se aguardar qualquer das sessões anunciadas

para constituir a comissão destinada a apreciar o pedido de impeachment, entregue

no dia $1^{\circ}$ de setembro. No dia imediato, o Diário da Câmara publicou ata da

reunião do Presidente, como disse, com os Lideres partidários, realizada nesse dia,

945 às 18 horas e 10 minutos, em que $S$. Exa e os demais participantes acordaram instituir a Comissão Especial para dar parecer ao pedido de impeachment da véspera, constituí-la com 49 membros titulares, igual número de suplentes, e distribuir as vagas entre as diferentes legendas.

Por meio de ata da Presidência desse mesmo dia, foram designados os seus

950 integrantes. O rito seguia seu curso de urgência: seis dias depois, oito de setembro, pela Mensagem no 013/92, fui comunicado da leitura e da tramitação da matéria, tendo sido assinado o prazo de cinco sessões, a esgotar-se às 19 horas do dia 15 de setembro, para, querendo, manifestar-me. Meus direitos começavam, $\mathrm{Sr}^{\mathrm{a}} \mathrm{s}$ e Srs. Senadores, a ser violados, contra a letra expressa do próprio Regimento

955 Interno da Câmara.

Concluí, então, que não haveria julgamento, Sr. Presidente, e menos ainda a isenção necessária que deve presidir o princípio do devido processo legal. Podia contar, quando muito, com uma sentença previamente prolatada.

Muitos pagariam qualquer preço para abreviar um julgamento que devia ser isento

960 e ponderado, ignorando todas as normas de um Estado de Direito democrático.

Sabia que, a partir daí, minha defesa e minhas razões seriam ignoradas. Mais uma vez, provei o travo amargo dos antagonismos que tanto marcam, infelizmente, a política em nosso País.

Quem recorrer ao primeiro dos quatro volumes editados pelo Senado sob a

965 denominação de Autos do Processo de Impeachment do Presidente da República vai constatar que as atas das sessões da Câmara, entre os dias 01 e 08 de setembro, páginas 399 a 420, estão ilegíveis porque são fotorreproduções das notas taquigráficas emendadas à mão. Tratava-se da aplicação do princípio da tal celeridade possível, proclamado pelo Presidente da Câmara. Não havia tempo

970 sequer para passar a limpo os rascunhos da taquigrafia, algo que nunca ocorrera nos Anais do Parlamento brasileiro.

No próprio dia 08, ante a decisão do Presidente da Casa, que indeferiu todas as questões de ordem suscitadas pelos Deputados Gastone Righi, Roberto Jefferson e Humberto Souto, que recorreram de seu autêntico ucasse, criou-se a Comissão

975 Especial, em seguida instalada, na mesma oportunidade em que foram eleitos seu Presidente, o Deputado Gastone Righi, três vice-presidentes e o relator, o Deputado Nelson Jobim.

Colocado ante o inusitado prazo de cinco sessões para manifestar-me, restavamme duas alternativas: submeter-me ao ato arbitrário ou recorrer ao Judiciário para

980 tentar restabelecer o império da lei no processo de cujos resultados já não me restavam mais dúvidas.

No dia 09 de setembro, o Dr. José Guilherme Villela, já constituído meu advogado impetrou o Mandado de Segurança que tomou o número 21.564-0/160, parcialmente deferido no dia seguinte pela mais alta Corte de Justiça do País, para

985 assegurar ao Presidente da República um prazo de dez dias para a sua defesa. Nessa mesma data, o Deputado Gastone Righi, na qualidade de presidente da Comissão Especial, solicitou ao Presidente da Câmara, pela primeira vez, a remessa dos autos da CPMI, da representação dos denunciantes e dos documentos a ela anexados.

990 Com a decisão do STF, o prazo para a apresentação de defesa foi dilatado, então, até o dia 24 de setembro. Em 21 do mesmo mês, a três dias de expirar-se o prazo da defesa, ante a petição do Dr. José Guilherme Villela, o Deputado Gastone Righi, Presidente da Comissão Especial requereu pela segunda vez, por escrito, a remessa dos autos da representação de impeachment. No dia 22, antevéspera de esgotar-se 
o prazo dado pelo Supremo Tribunal Federal para o exercício do direito de defesa, o Presidente da Comissão Especial comunicou ao Dr. Villela estar cimpossibilitado de atender à solicitação de vista feita duas vezes oralmente e, na terceira, por escrito, eis que não foram remetidos até a presente data, pela egrégia Presidência da Câmara, os originais da petição inaugural, os autos da CPMI e os documentos ali

1000 coligidos que embasam a inicial, apesar dos requerimentos encaminhados em 09/09/92 e reiterados em 21 de setembro de 1992.¿ Com essa atitude, a Comissão decidiria, sem ter conhecimento das acusações e dos autos do processo.

O açodamento encobria o propósito de violar os mais elementares direitos de quem estava em causa. Ao impor o prazo de cinco sessões à defesa, ao negar acesso aos

1005 autos da pretensa denúncia e ao não permitir a realização de diligências nem aceitar a indicação de provas e testemunhos, aquele que deveria servir de juiz e dirigir a decisão sobre o pedido de instauração do processo contra o Presidente da República ignorava, ao mesmo tempo, tanto expressas disposições regimentais daquela Casa, quanto provisões da Constituição Federal.

1010 Em primeiro lugar, o art. 188 do Regimento, que estipulava votação por escrutínio secreto no caso de instauração de processo contra o Presidente da República; em segundo lugar, o art. 217, ao prever que, perante a Comissão, o acusado ou seu defensor terá o prazo de dez sessões para apresentar defesa escrita e indicar provas; e, em terceiro lugar, as garantias do art. 50, inciso LV da Constituição

1015 Federal, ao dispor: caos litigantes, em processo judicial ou administrativo, e aos acusados em geral são assegurados o contraditório e a ampla defesa, com os meios e recursos a ela inerentes $\dot{\text {. }}$.

Apesar da generosidade de $\mathrm{V}$. Exas em ouvir-me, seria impossível ler, ainda que resumidamente, a prova de erudição e de cultura jurídica produzida pelo Dr. José

1020 Guilherme Villela, que me assistiu durante todo esse dramático momento da minha vida pública.

As alegações preliminares em minha defesa, caso inédito nos anais judiciais do País, foram produzidas sem que ao meu advogado fosse dado vista quer dos autos da CPMI, quer da petição sobre a qual a Câmara teria que decidir sobre a licença

1025 para instauração do processo de impeachment. Graças à sua qualificação profissional e ao seu profundo conhecimento da hermenêutica e do ordenamento jurídico do País, foi possível coibir alguns dos abusos, retificar vários erros e prevenir as mais graves agressões ao Direito praticadas contra o Chefe de Governo. Como advogado e jurista, coube-Ihe garantir alguns dos mais elementares direitos

1030 de qualquer cidadão, reparando, pelo menos, um dos mais graves abusos praticados no curso desses processos.

Repetir-se-ia, no âmbito da Câmara, portanto, o que já ocorrera durante os trabalhos da CPMI: a ligeireza e a forma precipitada como foram conduzidos os trabalhos. Foi nesse ambiente, coalhado de atropelos praticados em quase todas as fases do processo, que o Dr. José Guilherme Villela deixou consignado o lastimável procedimento quando, referindo-se aos sucessivos pedidos de acesso aos autos do processo, tornou explícito o seu protesto escrevendo que: ¿O advogado signatário não pôde examiná-los, sendo submetido, assim, ao constrangimento de defender seu eminente constituinte sem sequer conhecer as provas acusatórias. ¿

1040 Nem o mais tirano dos tribunais de exceção, Sr. Presidente, Sras e Srs. Senadores, teria atuado com mais eficácia do que o Presidente da Câmara na prática da urgência descabida e desnecessária, uma vez que, como escreveu Samuel Hungtinton: ¿O tempo é o único recurso absolutamente inadministrável da política.¿ Constrangido pelo Supremo Tribunal Federal a conceder-me o prazo de dez sessões

1045 para apresentação de sua defesa, S. Exa estipulou o dia 24 de setembro, data limite para que a Comissão Especial, para esse fim constituída, encerasse a deliberação a respeito da denúncia. Mesmo sem ter acesso aos autos, quer da CPMI, quer dos autores do pedido de processo, meu advogado apresentou sua defesa no dia 22 de setembro. Nessa mesma data, dois requerimentos firmados por vários deputados solicitaram a convocação de sessão extraordinária da Comissão 
Especial destinada a dar parecer ao pedido de instauração do processo de impeachment, que se realizou no dia seguinte, 23 de setembro às 20 horas. Desta mesma data é o parecer do Relator, o eminente Deputado Nelson Jobim, e de três outros requerimentos para que nova sessão extraordinária fosse realizada no 1055 dia seguinte.

Tal era a urgência com que se conduzia o processo que um dos pedidos propunha fosse a sessão realizada às 10 horas da manhã, a outra às 15 horas e a terceira às 21 horas. Feita a leitura do parecer, foi concedida vista conjunta aos Parlamentares que a requereram e convocada nova reunião para as 10 horas do dia imediato, 1060 quinta-feira, 24 de setembro, e outra no mesmo local e data, às 15 horas, para votação do parecer pela Comissão.

Na sexta-feira, 25 de setembro, em sessão plenária da Câmara, foi lido o parecer do Relator da Comissão Especial, Deputado Nelson Jobim, de quem os jornais da época, aliás, publicaram sugestiva foto, em que ele aparece assinando a peça em

1065 cima da perna, no corredor das comissões, concluindo: ¿Pela não apreciação do requerimento de diligências e de produção de provas, pela admissibilidade jurídica e política da acusação e pela conseqüente autorização para instauração, pelo Senado Federal, do processo por crime de responsabilidadec. Era, no mínimo, Sr. Presidente, a crônica da morte previamente anunciada.

1070 Na terça-feira seguinte, 29 de setembro, nova sessão extraordinária da Câmara deu continuidade à discussão do parecer, encerrado a requerimento dos Líderes do PMDB, do PDT, do PSB, do PT e do PST. Procedeu-se, a seguir, à votação que concluiu pela aprovação do parecer e a conseqüente comunicação ao Senado para abertura do processo. Encerrou-se aí apenas o segundo ato de um drama com 1075 muitos figurantes, inúmeros farsantes e poucos protagonistas. Tenho me referido de forma nominal aos personagens ainda vivos $\dot{i}$ esses personagens que viveram esses momentos. Com isso, respeito a memória dos já falecidos, mas não tenho como omitir o nome de alguns deles, a quem devo gratidão pela inteireza de sua conduta, pela sua convicção, pela coragem e 1080 desassombro de suas atitudes, pela firmeza de seu caráter e pela probidade de suas posturas.

Peço licença a este Plenário para tributar à sua memória a minha reconhecida reverência, repetindo aqui as palavras intrépidas com que afrontou as indignidades que contra mim se cometiam, ao encaminhar a votação do parecer que me afastou

1085 da Presidência. São mais do que esclarecedoras as suas palavras:

¿A decisão que vamos tomar não poderia ser tomada sem que se desse ao Presidente da República o tempo e a atenção necessários ao completo esclarecimento da verdade. Desde o princípio, condenei todo o processo, porque este é o primeiro caso no Brasil em que uma solicitação dessa ordem é feita no dia 109010 de setembro, e, hoje, dia 29, faltando quatro dias para a eleição, transforma-se este Plenário num tribunal de acusação. Por que, Sr. Presidente? É porque se desconfia do Legislativo? Essa decisão não seria a mesma no dia 7 de outubro? É porque se aproveita a eleição para tentar distorcer o resultado eleitoral? Não, Sr. Presidente, não me parece justo, não me parece correto. Até mesmo o Supremo

1095 Tribunal se transformou em tribunal político. Acato as decisões da Justiça, acato as decisões da maioria, mas devo registrar, neste instante, o meu protesto. ¿

As razões da sociedade celerada que insuflou meus adversários, ele as desvendou de forma crua, direta e premonitória.

Novamente, palavras dele:

1100 Não tenho compromisso com o erro, mas devo afirmar, neste instante, que a união de forças que se organizou para derrubar o Presidente da Republica, por certo e infelizmente, não vai durar muito..

Ser maioria é ser mais, nunca menos responsável pelas conseqüências dos atos, que, tomados majoritariamente, se tornam irremediáveis. Por isso mesmo, o

1105 Presidente da República está sendo vítima também dos seus acertos. Temos a política de modernização da economia de mercado, a diminuição das alíquotas de 
importação, tão necessárias para a modernização e para a competitividade de nossa indústria, a agenda de modernização dos portos, das marcas e patentes, a liberação de todos os preços, as reservas cambiais, os acordos externos, enfim, 1110 todo um lado positivo. $\mathrm{E}$, neste instante, é preciso que se tenha consciência das responsabilidades daqueles que poderão eventualmente exercer o poder. Não acredito, Sr. Presidente, em curto prazo, nas soluções dos nossos problemas econômicos, qualquer que seja o resultado desta votação, porque entendo que os grandes acordos feitos aqui [referindo-se ele à Câmara] são completamente

1115 insuficientes para resolver os nossos problemas econômicos.

Creio que, só com a Reforma Constitucional, poderemos diminuir o Estado, tirar as amarras e equacionar a questão do déficit público.

Entendo que este seria o momento de passar o País a limpo, e não simplesmente retirar o Presidente sem querer discutir, dando a vitória aos corporativistas e às

1120 elites brasileiras, que precisam repensar o modelo para o Brasil.

E concluiu:

Desde o início, o PFL deixou a questão em aberto, mas reafirmo minha posição: votarei contra o impedimento do Senhor Presidente da República. Concluo minhas palavras, dizendo que o interesse do povo, ao invés de uma razão, converte-se

1125 num pretexto para privá-lo de poder atender como bem quiser ao seu interesse. Reafirmo que sou responsável por meus atos e votarei contra o impedimento do Senhor Presidente da Repúblicac.

Os Anais indicam, Sr. Presidente, o clima reinante quando indicam apupos no plenário.

1130 Declino, com reverência e com emoção, o nome de quem o destino negou ao Brasil o direito e o privilégio de tê-lo como seu Presidente e que tanto honrou a Presidência da Câmara por sua firmeza e pela inteireza de suas convicções: Luís Eduardo Magalhães.

Receba, meu amigo, o tributo de minha eterna gratidão por seu desassombro, sua 1135 coragem e sua integridade. Não é só a Luís Eduardo que devo reconhecimento e gratidão pela atitude desassombrada e firme, não se deixando vencer pela pressão da maioria. Devo-a, também, a todos que, nas diferentes fases do processo naquela Casa, reagiram contra a sucessão de ilegalidades cometidas. Protestaram contra os abusos de que eu estava sendo vítima e lutaram, com as armas do direito

1140 e do bom senso, contra o ardiloso massacre que se armou com o uso dos mais condenáveis subterfúgios.

Não foi só no Congresso que encontrei exemplos de resistência às investidas de que fui vítima. Cito como exemplo desse elevado espírito público o nome do Governador Leonel Brizola, meu concorrente na eleição presidencial. Com sua reconhecida

1145 generosidade naquela hora difícil, tive o conforto do seu estímulo e de seu inestimável apoio, circunstância que terminou por aproximar-nos, fazendo-nos, mais do que parceiros dos mesmos ideais, amigos que a política aproximou, desmentindo a postura de radical que muitos pretenderam, sem êxito, atribuir-lhe, quer em vida, quer depois de sua morte.

1150 Desta Casa, Sr. Presidente, Sras e Srs. Senadores, o Senado Federal, naquele momento, sempre esperei ponderação, comedimento e serenidade, sobretudo em razão do fato já mencionado, que um dos primeiros atos da $46^{a}$ Legislatura tinha sido aprovar, na Câmara, projeto que retirava do Presidente da República poderes para edição de medidas provisórias, iniciativa rejeitada aqui pelo Senado.

1155 Fato ocorrido na composição da CPMI, porém, já tinha dissipado essa minha crença, a violação do princípio constitucional da proporcionalidade partidária na CPMI. Leio o que, a respeito, se encontra no livro, já citado, do Consultor Legislativo do Senado, Marcos Evandro Cardoso Santi:

Criada a Comissão no dia 27 de maio de 1992, a designação de seus membros, em

$116011^{\circ}$ de junho seguinte, continha o nome do Senador José Paulo Bisol, integrante do PSB, mas indicado pelo Senador do Partido Democrático Social, PDS, Esperidião

Amin, fato que desequilibrou a composição do colegiado em favor dos oposicionistas. 
No dia 30 de setembro, a Câmara oficiou esta Casa, autorizando a instauração do processo de impeachment. Nesta mesma sessão, o Presidente do Senado Mauro Benevides comunicou o recebimento do expediente e, incontinênti, convocou os Senadores para eleição da comissão incumbida de instruir o processo, composta de 21 integrantes e igual número de suplentes.

Deixou de exortar a que se reunissem para a escolha do Presidente, do Vice-

1170 Presidente e do Relator, respondendo questão de ordem proposta pelo Senador Odacir Soares, sobre as normas que regeriam o trabalho da comissão. S. Exa indicou na Constituição os dispositivos ainda vigorantes da Lei no 1079, de 1950, e o Regimento Interno do Senado.

A pressa e a urgência, Sras e Srs. Senadores, sempre foram más conselheiras.

1175 Quando usadas imoderadamente costumam tornar-se sinônimo de atropelo; e desse erro também fui vítima.

Ao responder ao Senador Nelson Carneiro, convocado por S. Exa para Presidir os trabalhos da Comissão, o Senador Benevides acrescentou: ¿Há realmente a indicação de que esta Comissão agora eleita inicie imediatamente os seus

1180 trabalhos, inclusive com a eleição do Presidente e Vice-Presidente e a escolha do Relatori.

Hoje, é lícito indagarmos a razão de tanta pressa e do empenho em acelerar o processo, uma vez esquecidas as circunstâncias sobre as quais tramitou o pedido de impeachment. A razão está nas palavras insuspeitas do Senador indicado para

1185 presidir a escolha dos dirigentes da Comissão especial.

Como estamos numa semana atípica na vida eleitoral brasileira, às vésperas de um pleito eleitoral, cabe-me, interpretando certamente o pensamento dos membros desta Comissão, convocar a reunião para dentro de 15 minutos, na sala número dois da ala Nilo Coelho, a fim de que a Comissão possa escolher os seus dirigentes.

1190 O grau de paroxismo, a alta temperatura que tinha inflamado o ânimo dos mais afoitos membros da Oposição exprimiam-se num aparte pouco usual, que durante esse debate deu o Senador José Paulo Bisol a seu colega Cid Carvalho. Cito-o textualmente e peço a atenção de $\mathrm{V}$. Exas a este aparte:

Nobre Senador Cid Sabóia de Carvalho, eu solicitaria, do melhor do coração de V.

1195 Exa ${ }^{a}$ que aproveitasse a posição que tem na tribuna neste momento e requeresse ao Presidente desta Casa que telefone para o Presidente do Supremo Tribunal, solicitando que S. Exa venha a esta Casa, porque em trinta minutos fazemos o despacho, encaminhamos a citação e suspendemos o Presidente da República das funções presidenciais para que o povo saiba que não somos farsantes.

1200 Que ligeireza e que facilidade!

Hoje, à distância dos 15 anos que nos separam desses episódios, custa a crer o grau de ansiedade que parece ter assaltado homens respeitáveis e austeros, tal a quantidade dos que se manifestaram com a mesma inconseqüência e com tal grau de irresponsabilidade, como se as instituições políticas democráticas pudessem se

1205 curvar a tantas insensatezes. Ali estavam os meus juízes, aquele era o tribunal que iria me julgar.

Antes da Ordem do Dia do dia 30 de setembro, o Presidente do Senado anunciou estar sobre a mesa o parecer da Comissão Especial que apreciaria o processo referente ao pedido de impeachment. Simultaneamente, dispensou a apreciação da

1210 Ordem do Dia, esclarecendo estar em seu poder requerimento de urgência com a assinatura de 39 Senadores, número insuficiente para a apreciação imediata do parecer sobre o prosseguimento imediato do processo. Em razão da falta de quorum para concessão da urgência, fez um apelo para que os Senadores permanecessem em Brasília no dia seguinte, sexta-feira, a fim de que fosse 1215 possível acelerar a tramitação do processo. Tal como ocorrera na Câmara, o afã pela urgência contaminara também o ambiente desta Casa.

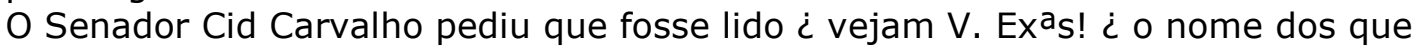
tinham assinado o pedido para que todos tomassem ciência dos que não tinham firmado o requerimento de urgência com o claro objetivo de que fossem pressionados a fazê-lo. O Presidente, atendendo mais do que pediu o requerente e 
numa atitude que em circunstâncias normais causaria pasmo por seu ineditismo, esclareceu que oito dos Senadores presentes tinham se recusado a assinar o requerimento. No entanto, um dos brasileiros mais íntegros dos que passaram por esta Casa, cujo nome declino também com respeito, o Senador Josaphat Marinho, reagiu indignado à condenável manobra.

Perdoem-me V. Exas citar na íntegra esse testemunho de honradez, probidade e isenção. Disse ele:

Atenderei o pedido de V. Exa, Sr. Presidente, permanecendo aqui até sexta-feira. Quero, porém, esclarecer que não subscrevi antes nem subscreverei o pedido de 1230 urgência para apreciação do parecer da Comissão Especial ainda hoje. Não o fiz por entender que a gravidade da matéria impõe que seja apreciada com presteza, mas sem precipitação. A decisão da Câmara se operou ontem. O processo entrou nesta Casa hoje. É um processo volumoso. Sabe-se que só a defesa do Presidente da República, apresentada à Câmara, tem 60 páginas. É até estranhável que a

1235 Comissão houvesse oferecido parecer hoje mesmo. Razão não há para que nesta sessão, ainda em regime de urgência, opere-se a decisão da matéria.

O Senado Federal começa a fazer o julgamento definitivo do Presidente da República por meio desse processo. Hoje mesmo, O Estado de S. Paulo traz longo editorial pedindo atenção sobre as formalidades que devem ser observadas a fim de 1240 que não pareça que há procedimento leviano no tratamento da matéria.

Pronto para apreciar e sem ter declinado até aqui o meu voto, pois só o farei na assentada do julgamento em tempo oportuno, apesar disso, não me parece que devamos andar com tanta pressa. É preciso que possamos dar à Nação a certeza de que estamos julgando criteriosamente. Exatamente nesse sentido, por essa

1245 razão, é que não assinei o requerimento e ainda agora não o farei por não me parecer adequado.

Ele encerra aí as suas palavras.

O discurso é prova da inteireza moral de Josaphat Marinho, de cuja intimidade não privei, mas cuja integridade sempre admirei. Era um dos poucos que até então não 1250 tinham externado sua opinião para não comprometer o seu voto quando o Senado atuasse como órgão judiciário, segundo manda a Constituição.

Pedi apenas critério no julgamento desta Casa, mas o único critério que orientava a maioria era o que demonstrava ser o desejo da maioria: o de afastar da Presidência quem não conseguiram afastar pelo voto soberano das urnas. Bastou esse pequeno pronunciamento, de poucas, mas eloqüentes palavras pronunciadas pelo nobre representante da Bahia, para salvaguardar naquele momento a dignidade da Representação Nacional.

O parecer da Comissão Especial, datado de 15 de setembro, a mesma em que teve início o processo oriundo da Câmara, possui dezessete linhas, sete das quais 1260 constituem a conclusão, que é a seguinte:

Satisfeitos os requisitos da lei, a Comissão é de parecer que deve ser instaurado processo por crime de responsabilidade nos termos postos na denúncia e no relatório circunstanciado, determinando-se a citação do Excelentíssimo Senhor Presidente da República, por si ou seu advogado, a apresentar a sua defesa e 1265 acompanhar o processo até o final da decisão.

A urgência e a leveza na apreciação do primeiro processo de impeachment que teve curso nos 103 anos da República prenunciavam como seria a tramitação nesta Casa, afinal o mesmo já tinha ocorrido na Câmara e, em última análise, idênticos eram os critérios que prevaleceram na condução da CPMI.

1270 Graças ao Líder do PRN no Senado, o Senador Ney Maranhão, no dia 10 de outubro, na mesma sessão em que afinal se aprovou a urgência para a tramitação do processo do Senado, o Diário do Senado publicou a entrevista ao Jornal do Brasil do Ministro da Fazenda, já demissionário, que sinto-me obrigado a registrar neste depoimento. Dizia ele:

1275 Nesses dezessete meses, não se tirou dinheiro do bolso do contribuinte, mas se restituiu. A inflação não explodiu. Não houve grande crescimento econômico, mas 
também não houve agravamento. Em agosto, o emprego em São Paulo melhorou conforme o Dieese. Não há mais controle de preços, mas também não existe desabastecimento. Não há filas, não existe ágio. Temos US $\$ 22$ bilhões de reservas 1280 líquidas internacionais. Nosso estoque de alimentos soma 14 milhões de toneladas. Isso é um seguro contra choques. Ouço as pessoas dizerem que a coisa está difícil, mas se sentem mais tranqüilas, porque não existem mais surpresas da noite para o dia.

A Nação, portanto, Sr. Presidente, apesar das manifestações de rua dos jovens

1285 estudantes, estava em paz e em ordem. Mas isso, lamentavelmente, naquela quadra difícil da vida brasileira, parece não ter sido percebido pelos que ainda não tinham se acostumado à jovem democracia brasileira, que então firmava seus primeiros passos. para a instauração do processo, o Senado dispensou a Ordem do Dia, elegeu a Comissão Especial do Impeachment, escolheu os seus dirigentes e o relator e, na mesma ocasião, aprovou o parecer favorável da Comissão Especial ao seu prosseguimento. A votação em plenário só não ocorreu na mesma sessão em regime de urgência por falta de quorum e graças à intrépida e serena intervenção 1295 do Senador Josaphat Marinho, como já assinalei. Consumou-se, porém, no dia seguinte, $1^{\circ}$ de outubro, às vésperas da eleição municipal. Com a participação do Presidente do Supremo Tribunal Federal, foi elaborada a notificação que me foi apresentada sob a forma de contrafé e por mim assinada às 10 horas e 20 minutos no Palácio do Planalto. Chamo a atenção para esse horário, pois a reunião da Mesa

1300 desta Casa que decidiu essa formalidade e aproveitou seus termos teve início, conforme se lê na ata publicada às folhas 789 do Diário do Senado, às 12 horas. Como se constata e se comprova pelo órgão oficial, Sr. Presidente, a notificação precedeu a sessão da Comissão Diretora desta Casa que a decidiu e aprovou seus termos. Não tenho notícia, Sras e Srs. Senadores, de precedente igual ou

1305 semelhante em nenhum tribunal de qualquer país democrático. Essa avidez, já do domínio público, tinha sido condenada na véspera em editorial do jornal $O$ Estado de S. Paulo, com o título ¿O Supremo em Risco ¿, em que advertia:

Ao longo dos dias, alertamos a opinião pública para grave problema. Qual a lei que regerá a instauração de instrução do processo do Presidente da República pelo

1310 Senado Federal? Suscitamos as dúvidas e para nenhuma delas houve resposta satisfatória. Com isso, corre-se o risco agora de o Chefe de Estado ser processado por normas feitas ad hoc.

O temor a que se referiu o editorial de $O$ Estado de São Paulo não fez mais do que ser confirmado no dia 6 de outubro, quando o Presidente do Supremo Tribunal

1315 Federal, Ministro Sidney Sanches, comunicou ao então Presidente da República o roteiro do procedimento de impeachment elaborado por S. Exa. Era efetivamente um roteiro sob medida, como denunciara o jornal paulista. Convalidava, inclusive, medidas já tomadas pelo Senado. Mais uma vez, Sr. Presidente, as decisões se antecipavam às deliberações. Muitos dos atos e prazos a serem cumpridos

1320 efetivamente já tinham sido praticados.

A segunda reunião da Comissão Especial realizou-se no dia 7 de outubro. A ata respectiva sequer indica a hora do início dos trabalhos, embora registre a do encerramento. No dia 13, representado pelos advogados José Guilherme Villela, Antônio Evaristo de Moraes Filho e Fernando Neves, atual Presidente do Conselho

1325 de Ética Pública da Presidência da República, habilitei-me perante a Comissão, na expectativa de exercer os direitos que me tinham sido negados na Câmara.

A esses exemplares profissionais, a cuja cultura jurídica e competência intelectual devo, além da obstinação, o devotamento e a integridade de suas condutas, quero consignar aqui o meu reconhecimento. Em especial a Fernando Neves, Sr.

1330 Presidente, de quem me tornei, além de amigo, eterno devedor, deixo registrado o meu profundo agradecimento. À falta de lei que regulasse o processo, fui submetido a normas elaboradas por quem ia presidir o meu julgamento, e 
aprovadas pelos que iam julgar-me. Além de inédito, inusitado, incomum era o processo a que eu seria submetido logo em seguida.

1335 As eleições municipais de 1992 tinham acabado de se realizar sob o fragor das emoções desencadeadas pelo movimento orquestrado, executado e consumado para promover o meu impedimento. Durante a semana destinada à votação e apuração das eleições de 3 de outubro, cessou temporariamente o combate encetado pelas marcas deixadas pelos pleitos de 15 de novembro e 17 de

1340 dezembro de 1989. Foi a única trégua em todo aquele martírio. É possível que naquele intervalo de alguns dias, alguns dos objetivos dos que me acusavam já tivessem sido atingidos com o resultado das urnas.

Os meses de outubro e novembro foram consumidos pela simples reedição dos trabalhos encetados entre maio e setembro pela CPMI.

1345 Afastado do Governo desde o dia 10 de outubro, restava apenas o ato final que consumaria a minha deposição: o julgamento pelos que já tinham formado o seu juízo, muitos dos quais antecipados publicamente.

Em face da falta de provas materiais para condenar-me por atos cometidos no exercício da Presidência da República, restou o recurso de se reeditar o mesmo

1350 roteiro da CPMI, que, entre $1^{\circ}$ de junho e 28 de agosto, investigou as denúncias contra Paulo César Farias.

Em quatro das doze reuniões, a Comissão inquiriu e ouviu o depoimento de doze testemunhas, a última das quais o ex-Ministro da Fazenda, por encontrar-se ausente do Brasil.

1355 No dia 9 de novembro, encerrados os trabalhos da Comissão Especial, os autores da denúncia apresentaram as alegações finais, publicadas nas páginas 1.585 a 1.674, no Diário do Senado, como órgão judiciário, edição do dia 11 de novembro, com as mesmas imputações da representação inicial, solenemente entregue no Salão Negro do edifício do Congresso Nacional aos Presidentes da Câmara e do

\section{Senado.}

No dia 10 de novembro foram intimados os meus advogados para, no prazo de quinze dias, apresentarem as alegações finais. Pela primeira vez, em todo o curso do processo, observaram-se os prazos legais, ao contrário do que até então tinha ocorrido na Câmara. A exigência cumpriu-se no dia 25 de novembro, podendo ser consultada às fls. 1.775 a 1910 do Diário do Senado já referido.

No dia seguinte, manifestou-se a acusação sobre as alegações finais da defesa. $\mathrm{Na}$ última reunião da Comissão, em 27 de novembro, ante o protesto do Dr. Evaristo de Moraes Filho por não ter sido dada oportunidade à defesa para manifestar-se sobre o depoimento do ex-ministro da Fazenda, foi lido o parecer do Relator.

1370 Desde o início deste depoimento, Sr. Presidente, Sras e Srs. Senadores, fiz questão de acentuar as medidas arbitrárias praticadas contra o exercício do meu direito de defesa e de ressaltar, sempre que necessário, os sucessivos atropelos ocorridos tanto na Câmara quanto no Senado em relação aos procedimentos legais, que ora não foram respeitados, ora foram ignorados.

1375 Devo ressalvar, porém, a diferença de tratamento dada pelo eminente Relator, Senador Antônio Mariz. Primeiro, em sua intervenção inicial, resumida a dezessete linhas, para acatar a imediata tramitação do processo; e, mais tarde, na apresentação do parecer da Comissão, quando buscou embasar suas opiniões em documento sereno, em eloqüente contraste com o subscrito na fase vestibular da 1380 tramitação da denúncia.

A observação não supõe, obviamente, minha concordância nem com as afirmações e menos ainda com as conclusões desse documento. Por isso mesmo, devo assinalar que, embora não tivesse sido objeto de investigação da CPMI encerrada em agosto, foram os seus elementos os mesmos utilizados na conclusão do 1385 parecer.

A Comissão esmerou-se, sem dúvida, em buscar provas e pesquisar indícios para me incriminar. $\mathrm{E}$, pela primeira vez $\dot{c}$ espero que tenha sido a última $\dot{c}$, o Presidente da República teve quebrado o seu sigilo bancário, suas sucessivas declarações de 
bens, seu sigilo fiscal e até mesmo o sigilo telefônico de sua residência particular, o que ocorreu também em relação às linhas e ramais do Palácio do Planalto. Lido e aprovado o parecer do Relator no dia 27 de novembro e publicado no dia imediato, os Presidentes do Supremo e do Senado assinaram convocação conjunta para a sessão que, no dia 2 de dezembro, deveria discutir e votar o parecer aprovado pela Comissão Especial.

1395 A manifestação do Relator coincidia tanto com as conclusões do Relator da CPMI quanto com as imputações dos autores da denúncia. Penso que vale o cotejo. $O$ Relator da CPMI imputou-me atos de improbidade administrativa e atos incompatíveis com a dignidade, a honra e o decoro de Chefe de Estado. Os autores da representação à Câmara declararam a minha conduta incompatível com a

1400 dignidade, a honra e o decoro para o exercício da função pública e acusaram-me de permitir, com minha omissão, de forma tácita ou expressa, infração a lei federal de ordem pública, ou seja, afronta às leis penais e administrativas. E, finalmente, o Relator da Comissão processante do Senado considerou-me culpado de permitir, de forma expressa ou tácita, a infração de lei federal de ordem pública e de proceder

1405 de modo incompatível com a dignidade, a honra e o decoro do cargo.

As três conclusões mostram uma convergência de opiniões e juízos pelo menos pouco usual nos Parlamentos, onde a divergência e o pluralismo costumam ser a tônica dos debates e das decisões. Os oradores que tentaram caracterizar a autonomia da aceitação do parecer em relação ao julgamento dele decorrente

1410 participavam apenas de uma encenação que mascarava suas próprias indecisões. $\mathrm{Na}$ realidade, o parecer era apenas, como demonstrou o Senador Josaphat Marinho, um entreato de uma decisão que já estava tomada.

Em suas próprias palavras:

Previstos dois julgamentos, se, no dia de hoje, o Plenário do Senado, asseverar, 1415 como fez a Comissão Especial, que se encontra demonstrada a materialidade dos delitos descritos na denúncia, que estão tipificados os crimes e que são procedentes as acusações, terá prejulgado definitivamente o caso. Será ilógico que o Plenário reconheça desde logo tais fatos, nas condições expostas no parecer, e possa, afinal, no outro julgamento, decidir em sentido contrário.

1420 O que se tentava ocultar com tal subterfúgio eram, em última análise, os propósitos claros que animavam os meus antigos adversários.

A minha sorte, Sr. Presidente, Sras e Srs. Senadores, mais do que lançada, já estava selada. Não me restava qualquer alternativa.

Na véspera dessa decisão, o STF comunicara ao Presidente daquela Corte, na

1425 qualidade de Presidente do Senado, como órgão judiciário, o indeferimento da liminar solicitada por meus advogados no mandado de segurança que impetrei. E, no dia 8 de dezembro, S. Exa, depois de indeferir as perícias tempestivamente requeridas por meus defensores, designou o dia 22 de dezembro, às 9 horas da manhã, para que tivesse início a sessão de julgamento do impeachment. Tratava-

1430 se, como se vê, de mera formalidade, uma vez que o objeto da reunião era apenas o de sancionar o veredicto de culpabilidade constante do parecer da Comissão Especial, já aprovado pelo mesmo Plenário que deveria julgar-me.

No dia 15 de dezembro, data do encerramento da sessão legislativa de 1992, os Presidentes da Câmara e do Senado, usando da faculdade que Ihes concedia o

1435 inciso II, $\S \S 6^{\circ}$ e 70 da Constituição Federal, convocaram extraordinariamente o Congresso para, entre outras matérias, deliberar sobre o processo de impeachment.

No dia seguinte, S. Exa deferiu a juntada aos autos da seguinte certidão:

A pedido do Senhor Presidente da República, Fernando Collor de Mello, certifico que

1440 determinei a realização de busca nos arquivos do Tribunal de Contas da União nesta data, no sentido de verificar se existe processo, em curso ou já julgado por esta Corte de Contas, em nome do requerente, e que foi concluído o trabalho feito junto ao serviço eletrônico de controle de processos do Tribunal, com o esclarecimento de que nada existe que o incrimine moral ou administrativamente 
Brasília, 16 de dezembro de 1992.

Élvia Lordello Castelo Branco, Vice-Presidente no exercício da Presidência.

Não havia mais fatos, recursos, argumentos, evidências, indícios ou provas capazes de demover a maioria da representação política nacional, que já tinha se decidido por minha condenação.

No dia 21 de dezembro, véspera da data aprazada para o julgamento, meus advogados, Antonio Evaristo de Moraes Filho, José Guilherme Villela e Fernando Neves, cumpriram sua última missão perante o Congresso Nacional: entregaram ao Presidente da Suprema Corte, na qualidade de presidente do julgamento do

1455 impeachment, a carta em que, reiterando a confiança que neles depositava para continuarem defendendo os meus direitos no processo perante o STF, revoguei o mandato a eles confiado para minha defesa no Senado.

O Presidente declarou a revelia e nomeou defensor dativo o professor Inocêncio Mártires Coelho, ex-Procurador-Geral da República. Marcou nova sessão para o dia

146029 de dezembro, ao mesmo tempo em que notificava as testemunhas arroladas pela defesa. Mais uma vez convocou-se o Congresso Nacional para reunir-se em caráter extraordinário, no período de 25 a 31 do mesmo mês.

$\mathrm{O}$ ato legítimo custou-me novos e virulentos ataques, incompatíveis com a dignidade e a seriedade do ambiente em que foram proferidos, prontamente 1465 repelidos pelo Senador Áureo Mello.

Não me veio à mente, Sr. Presidente, a frase de Cesar ao atravessar o Rubicão, pois a minha sorte, há tempos, já estava selada. Lembrei-me, sim, de Voltaire, que disse: ¿mentez, mentez, quelque chose restera ¿ ¿ mintam, mintam, que sempre alguma coisa acaba ficando.

1470 Constituí novo defensor, o Dr. José Moura Rocha, que se habilitou perante o Senado e requereu vista de trinta dias. O prazo foi negado em face de ter sido mantido o dia 29 de dezembro para o julgamento do impeachment.

Os fatos ocorridos naquela oportunidade são do conhecimento público. Iniciada às 9 horas a sessão cujo resultado era de antemão conhecido, autorizei meu advogado a 1475 entregar o documento pelo qual renunciei à Presidência. No mesmo ato, o Dr. Moura Rocha requereu, como mandam a doutrina e o art. 15 da Lei no 1.069, de 1950, que regula o impeachment, a extinção do processo.

O Presidente do Senado havia comunicado ao meu defensor, como este deixou registrado nos Anais, ser imperativo de ordem constitucional submeter o ato

1480 unilateral de renúncia ao Congresso Nacional. As atribuições privativas do Congresso estão discriminadas no art. 49 da Constituição, e entre nenhum de seus 17 incisos consta esse imperativo.

Para quem já havia cometido tantos atos falhos, mais este não alteraria o curso dos acontecimentos, entre outras razões, porque, desde $1^{\circ}$ de outubro, estava eu

1485 afastado da Presidência, então exercida por meu substituto.

Suspensa a sessão de julgamento pelo Senado Federal às 9 horas e 43 minutos da manhã, os trabalhos foram reabertos à 1 hora e 40 minutos da tarde, para que se decidisse sobre a continuidade ou a extinção do processo.

A Constituição Federal concede ao Presidente do Supremo Tribunal Federal o

1490 privilégio de presidir a sessão do Senado Federal no julgamento do Presidente da República e de seus Ministros por crime de responsabilidade. Essa cautela dos Constituintes de 1946 foi recepcionada pela Constituição em vigor, para assegurar a isenta condução do julgamento.

Se não há julgamento em decorrência do falecimento, da renúncia do acusado ou

1495 de qualquer outro motivo superveniente em que se dá a extinção do processo, o Presidente da Corte Suprema não tem por que presidir o Senado, pois somente pode fazê-lo quando esta Casa atua como órgão judiciário. Supõe-se que, nessa hipótese, seu dever seja declarar extinto o processo e retirar-se do recinto, dando por finda a missão que lhe é reservada pelo parágrafo único do art. 52 da

1500 Constituição Federal.

Em meu julgamento, no entanto, S. Exa, em vez da toga de magistrado, vestiu a 
túnica de Pilatos e, como romano, lavou as mãos para livrar-se de sua responsabilidade, entregando-a ao arbítrio do Plenário. S. Exa suspendeu a sessão às 9 horas e 43 minutos, como eu disse, e a reabriu quatro horas depois, para,

1505 segundo suas palavras, ¿̇ver se o processo deve ser extinto ou nãocं. Ao lado do advogado da acusação, manifestaram-se todos os Senadores favoráveis ao prosseguimento do processo, legalmente já extinto depois da renúncia. $A$ exceção foi, mais uma vez, o Senador Josaphat Marinho, que, contraditando a maioria, invocou o art. 52, parágrafo único, da Constituição, segundo o qual a

1510 condenação limitar-se-á à perda do cargo, com inabilitação por oito anos para o exercício de função pública, sem prejuízo das demais sanções judiciais cabíveis. E ele vem com a sua intervenção e conclui:

Ou reconhecemos logicamente que a renúncia recebida e admitida e tendo produzido os seus efeitos obsta também esse processo, ou estamos adotando uma dupla interpretação para o mesmo ato. De um lado, reconhecemos que a renúncia é correta, não é uma hábil manobra, para lembrar a expressão usada pelo nobre advogado Evandro Lins e Silva, ou é um ato perfeito. Ou é uma coisa, ou outra. Ato perfeito foi considerado pelo Congresso Nacional, que Ihe deu todas as conseqüências. O Presidente da República agora é o Senador Itamar Franco.

1520 Fernando Collor de Melo é cidadão brasileiro. Perdemos, portanto, a condição de Tribunal Especial para julgá-lo neste instante. Por interpretação lógica, por interpretação literal, por qualquer interpretação legítima, só há inabilitação para o exercício da função pública, se houver a condenação à perda do cargo. Á perda do cargo já não podemos condenar quem dele abrir mão, com todos os efeitos já

1525 produzidos. Vamos, então, prosseguir como e para quê?

Enquanto o Senador Josaphat Marinho falou pela consciência jurídica do País, seu Colega, o Senador Jarbas Passarinho, exprimiu sua postura sob o ponto de vista político.

Disse ele:

1530 Não posso entender, Sr. Presidente, algumas questões que ouvi aqui, a partir do ilustre Patrono da Acusação, de que a inabilitação era cautelar. Era a necessidade de impedir que voltasse a ter ações públicas, sobretudo o voto popular para funções eletivas, aquela pessoa que, no momento, já renunciou à Presidência da República. Isso seria, aí sim, mostrar o medo que temos do povo. Quando se falou

1535 em povo, que o povo exige uma punição, por que ter medo do povo, dizendo que amanhã, se ele não for inabilitado, voltará à Presidência da República ou a qualquer outra função eletiva? Seria o povo, por intermédio de um referendo popular, acusando-nos, aí sim, de termos sido um tribunal de exceção que não agiu de acordo com a justiça e por isso o povo reclama a necessidade de corrigir o erro de 1540 um tribunal de exceção?

Sr. Presidente, se prosseguirmos nesse processo, tenho a impressão de que vamos lavrar exatamente a sentença de nosso medo. Meu eminente Colega Cid Sabóia de Carvalho disse que o povo quer a punição. Pelo menos, o eminente Senador Antonio Mariz, em sua colocação brilhante, fez a mesma afirmação. Estaremos nós, 1545 neste momento, tomando uma decisão apenas porque receamos que o povo lá fora não entenda que queremos impunidade? Ou queremos que este Senado seja respeitado pela autonomia e coragem que tem de decidir?

Não me cabe dizer se o ex-Ministro Jarbas Passarinho falou pela história. O que sei é que a história deu o seu veredicto. A censura, nos atos dos Presidentes do

1550 Senado e do STF, quando esta Casa atuou como órgão judiciário, não se cingiu aos que se manifestaram no âmbito do Congresso. Repercutiu também na área acadêmica em textos dos mais renomados juristas. Celso Ribeiro Bastos, em seus Comentários à Constituição do Brasil...

O Sr. Garibaldi Alves Filho (PMDB ¿ RN) ¿ V. Exa me permite um aparte?

1555 O SR. FERNANDO COLLOR (Bloco/PTB ¿ AL) ¿ Pois não, Senador Garibaldi Alves Filho, por favor.

O Sr. Garibaldi Alves Filho (PMDB ¿ RN) ¿ Presidente Fernando Collor, fui um 
daqueles que estavam presentes no Senado, como Senador, naquele dia em que V. Exa foi suspenso das funções de Presidente da República e em que, ao mesmo

1560 tempo, teve seus direitos políticos cassados. Reconheço que, voltando àquela cena de muitos anos atrás ¿ são quinze anos, para ser mais exato, de acordo com o Senador Romeu Tuma, que me ajuda $\dot{c}$, eu não teria muita coisa a dizer, até porque não estou aqui para contestar $V$. Exa, como também aqui não estou para me penitenciar. Estou aqui para dar um depoimento, neste momento em que $V$. 1565 Exa me dá a oportunidade de, tendo assumido essa posição, poder dizer-lhe, com relação a mim, o que aconteceu. Digo a V. Exa que, depois da sua cassação, passei a me preocupar mais com a investigação dos fatos reais, porque, de fato, notei que o que estava sendo apurado na CPI não estava levando a um conhecimento maior os Senadores que não participaram da CPI, mas que participaram do seu

1570 julgamento. Sendo assim, não estou sendo cobrado por ninguém, estou sendo cobrado por minha consciência. Confesso a V. Exa que, depois de quinze anos, quando V. Exa volta ao cenário político, vejo-me na situação de ter de enfrentar esse fato, o fato de que fui um daqueles que, como disse V. Exa, concorreram para que $V$. Exa sofresse tantas amarguras, tantas agruras e tantos sofrimentos. Quero

1575 dizer a V. Exa que, na verdade, depois, fiz parte da CPI do Orçamento, como SubRelator, e da CPI dos Bingos, como Relator, com a preocupação dessa apuração. Sei que há excessos numa CPI, mas, como se diz do próprio regime democrático, há algo mais eficiente do que a CPI para apurar fatos com relação ao Congresso Nacional, quando o Congresso Nacional adquire e assume aquelas prerrogativas do

1580 Poder Judiciário? Então, Presidente Collor, queria dizer a V. Exa , concluindo, que, depois de todo o discurso de $V$. Exa, propriamente não estou com a consciência tranqüila. Digo isso com toda serenidade. Não estou aqui para me penitenciar, mas não estou com a consciência absolutamente tranqüila pelo fato de que o relato que V. Exa faz me coloca no centro dos acontecimentos, pelo menos com relação à

1585 minha memória, como se tivesse existido um processo, uma armação contra V. Exa. Não vou colaborar para esse julgamento, mas quero reconhecer que o Supremo Tribunal Federal, depois, absolveu V. Exa. O povo de Alagoas o mandou para cá. E estou aqui, como representante do Rio Grande do Norte, novamente como Senador, na expectativa de que o Brasil possa não ver repetidos aqueles

1590 acontecimentos, não apenas pelo infortúnio que trouxeram a V. Exa, mas pelo tumulto que trouxeram à vida brasileira. Agradeço à V. Exa a oportunidade que me dá.

O SR. FERNANDO COLLOR (Bloco/PTB ¿ AL) ¿ Senador Garibaldi Alves, gostaria de dizer a V. Exa que, em nenhum momento, sou contra o instituto do

1595 impeachment; em nenhum momento, sou contra a que se criem CPIs ou CPMIs. O que defendo $\dot{c}$ e tenho certeza de que também $V$. Exa e todos os integrantes desta Casa o defendem, até porque somos legisladores e, quando formulamos e fazemos leis, assim agimos na presunção de que elas sejam seguidas e obedecidas $i$ é que as leis não sejam violadas, que a Constituição não seja violentada.

1600 Nesse caso específico, em que o Senado atua como órgão judiciário, está muito clara a Constituição. No momento em que não há mais a figura do Presidente, em que o Senado só pode reunir-se como tribunal para julgar o Presidente da República, depois de todos esses outros atropelos jurídicos havidos ¿ para utilizar um termo mais suave $\dot{c}$, no momento em que o Senado Federal atua como tribunal, isso se dá para que se julgue o Presidente ou seus Ministros.

1605 No momento em que apresentei minha carta-renúncia, como dizem aqui todos, deixou de haver Presidente, não havia mais o que julgar. $E$, mais do que ninguém, o Presidente do Supremo Tribunal Federal à época ¿ que, pela Constituição é quem devem presidir o Senado reunido como tribunal $\dot{c}$, como guardião das leis e

1610 conhecedor delas em profundidade, sabia dos seus limites. É por isso que digo aqui que ele, cândida e docemente, lavou suas mãos e deixou para que o Plenário decidisse o que já estava decidido pela manifestação da maioria dos Srs.

Senadores, mesmo antes de as eleições terem sido processadas, em $1^{\circ}$ de outubro 
¿ outra coisa que, como todos sabemos, não pode acontecer. Nós, Senadores, se estivermos aqui participando de uma sessão do Senado como tribunal, não podemos exarar nosso voto, porque somos juízes. Se exararmos nosso voto, se publicarmos nosso voto, podemos ser impedidos de participar do julgamento. É contra isso que me insurjo. Não me insurjo contra o fato de ter-se instalado a CPMI, tanto que não criei nenhum tipo de obstáculo para que ela se instalasse, não

1620 criei nenhuma dificuldade para que todos os dados fossem fornecidos. Mas eu, $\mathrm{V}$. Exa e todos nós temos de nos insurgir quando vemos que a lei está sendo flagrantemente violada, com interesses políticos subalternos animando essa ação. É claro que, nesse roldão, ao sabor das emoções que foram desencadeadas naquele instante, muitos de nós poderíamos ter sido levados por isso, o que é humano.

1625 Agradeço muito a V. Exa suas palavras e a atenção com que está ouvindo meu discurso, porque vi que $V$. Exa percebeu que alguma coisa de equivocado aconteceu nesse processo. E o que aconteceu de equivocado, Senador Garibaldi, foi exatamente a violação, a violentação da nossa Constituição e das leis vigentes no País.

1630 Aqui, cito alguns dos nossos juristas. Celso Ribeiro Bastos, respondendo ao tópico ¿A renúncia do Presidente da República extingue ou não o processo por crime de responsabilidade? $\dot{i}$, conclui:

Há que notar que o propósito que tem em mira o impeachment não é propriamente o de punir o acusado, mas, sim, o de destituí-lo do cargo. No passado, nossas

1635 Constituições até mesmo não impunham a pena obrigatória de inabilitação por determinado tempo no futuro. Essa era e continua, no fundo, a ser uma pena acessória, uma pena decorrencial da outra, que é logicamente procedente, qual seja, a perda do cargo por julgamento do Senado.

E continua ele:

1640 O impeachment é um instituto, em si, voltado a coisas grandes, à defesa da pátria, à preservação da coisa pública, à preservação da própria Constituição. É a isso que o instituto está volvido, não a transformar-se num instrumento canhestro de expansão de sentimentos condenáveis e espúrios.

Diz Ives Gandra Martins:

1645 No julgamento do Presidente Collor, o Presidente do Supremo, exercendo a função de condutor do julgamento, fez notar o caráter jurídico-político, ao admitir a continuação de um julgamento para retirar direitos de um presidente que renunciara às suas funções e que, portanto, segundo a abalizada doutrina, não mais poderia ser julgado pelo Senado. Com brilhantismo, o Senador Josaphat

1650 Marinho [continua o Dr. Ives Gandra] insistiu na ilegalidade do processo. Mas o Presidente do Supremo Tribunal Federal houve por bem remeter ao Plenário a decisão, abdicando de sua função de dizer o direito, para que prevalecesse a opinião não jurídica, mas política, da Casa legislativa dos Estados. E, ao assim agir, abriu, no meu entender [continua o professor Ives Gandra], nova conformação

1655 técnica do julgamento de um Presidente da República nos crimes de responsabilidade pelo Senado Federal, fazendo nele prevalecer o elemento político sobre o jurídico.

\section{O Sr. Joaquim Roriz (PMDB ¿ DF) ¿ Sr. Presidente Fernando Collor, peço-Ihe um} aparte?

1660 O SR. FERNANDO COLLOR (Bloco/PTB ¿ AL) ¿ Ouço o Senador Joaquim Roriz. O Sr. Joaquim Roriz (PMDB ¿ DF) ¿ Sr. Presidente Fernando Collor, estou assistindo ao depoimento de $V$. Exa com muita atenção. Há exatamente 2 horas e 34 minutos, V. Exa está falando. E ainda não terminou. Desculpe-me interrompê-lo. O SR. FERNANDO COLLOR (Bloco/PTB ¿ $A L$ ) ¿ Não é nada, Senador.

1665 O Sr. Joaquim Roriz (PMDB ¿ DF) ¿ Mas eu gostaria apenas de dizer que nada acontece por acaso. V. Exa tinha um destino, que era ser o primeiro presidente eleito após o regime ditatorial. Foi eleito pelo povo. V. Exa cumpriu essa missão. $V$. Exa foi afastado do governo, e duas coisas me chocam muito, Sr. Presidente: a injustiça e o desprezo pelos pobres. Quantas injustiças V. Exa sofreu? Eu, aqui, em 2 duas horas e 44 minutos, percebi a angústia de V. Exa. Imagino V. Exa, 
angustiado, durante quinze anos! Foram 15 anos de noites indormidas, sofrendo! E nunca ouvi uma palavra de agressão a quem quer que seja partindo de $V$. Exa. Essa é uma missão, uma missão que $V$. Exa tinha de cumprir. $E$ foi uma provação para V. Exa. Fique certo de que, hoje, V. Exa retorna à vida pública com galhardia, como homem cônscio de sua responsabilidade. Eu estava assistindo ao seu pronunciamento como se estivéssemos aqui cantando o Hino Nacional, com V. Exa na postura de respeito ao Hino Nacional. V. Exa voltou ao Congresso Nacional, ao Senado, para mostrar ao brasileiro que cometeram uma grande injustiça com $\mathrm{V}$. Exa. Fui solidário ao seu Governo e sou solidário à sua postura. Quero dizer que a

1680 única forma que tenho de homenageá-lo, neste dia em que V. Exa retorna oficialmente ao Senado, é suspendendo minha inscrição. Já que eu ia falar, vou suspender minha inscrição, para que o discurso de V. Exa tenha mais repercussão no Brasil inteiro, entre todos os jornalistas que aqui o estão acompanhando. Parabéns, Sr. Presidente, pelo depoimento!

1685 O SR. FERNANDO COLLOR (Bloco/PTB $\dot{A} \mathrm{AL}$ ) $¿$ Muito obrigado, Senador Joaquim Roriz. Dos gratos momentos que guardo na minha memória como ex-Presidente da República, vários deles foram compartilhados com V. Exa, quando Governador de Brasília. Discutíamos as questões pelas quais nossa Capital ansiava, como a disseminação dos CIACs por todas as cidades satélites, como a inauguração do primeiro Ciac, no Paranoá. E me lembro da alegria com que visitávamos essas obras, da alegria que víamos no sorriso das crianças, amparadas por aquela iniciativa de governo.

Isso me traz à lembrança também outro fato: no momento em que deixei o Palácio do Planalto, peguei o helicóptero. Eu me preocupava, como V. Exa sabe, com o 1695 andamento das obras. Naquela época, estava para ser concluído o Ciac de Santa Maria. Pedi ao piloto que, antes de me levar ao destino, sobrevoasse a cidadesatélite de Santa Maria, para que eu pudesse ver como estavam as obras. E o piloto, então, informou-me: ¿Negativo, não tenho combustível suficiente no helicóptero para fazer esse sobrevôoc. E era um sobrevôo de mais cinco minutos ou

1700 dez minutos. Naquele exato momento, senti que a Presidência a que o povo havia me levado já não mais pertencia a esse povo, nem a mim.

Portanto, suas palavras me servem de reconforto, Senador Joaquim Roriz, e também me trazem enorme alegria, porque, como eu disse no início, guardo na minha memória os momentos em que estivemos juntos $\dot{i} \mathrm{~V}$. Exa governando nossa

1705 Capital, e eu, nosso País. Lembro-me da dedicação de V. Exa pela sua cidade, das solicitações que sempre me fazia $\dot{c}$ aí está o metrô, que foi iniciado também naquele período, com o apoio do Governo Federal $\dot{c}$, mas, sobretudo, lembro-me da forma como V. Exa se dedicou a disseminar aquelas unidades de ensino integral, para dar acolhida às nossas crianças.

1710 Muito obrigado, Senador Joaquim Roriz, por suas palavras.

Sr. Presidente, $\mathrm{Sr}^{\mathrm{a}} \mathrm{s}$ e Srs. Senadores, concluindo, quero dizer que não foi fácil viver aqueles momentos, em que todas as virtudes estavam num prato da balança e em que, no outro, estavam todos os vícios. A mim, nem o benefício da dúvida foi concedido. A reparação dos agravos, das ofensas e das injúrias, encontrei-a no

1715 Pretório a que todos os injustiçados pensam em recorrer, mas a que poucos, efetivamente, apelam por não estar ao alcance da maioria preponderante dos brasileiros: o Supremo Tribunal Federal.

A peça acusatória do Procurador-Geral da República era apenas corrosiva ¿ sabia eu que era inepta e inócua. Era fruto contaminado da mesma árvore de cuja seiva se

1720 nutriam meus adversários. Os autos da Ação Penal no 307-3/DF, que estão disponíveis no site do Supremo Tribunal Federal, são o testemunho mais eloqüente, mais definitivo, mais expressivo e mais convincente tanto da falta de fundamento da acusação quanto da inépcia da denúncia.

Em seu relatório, o eminente Ministro Ilmar Galvão sintetizou os atos e fatos ilícitos de que fui acusado e que falam por si. O voto do eminente Relator do Supremo Tribunal Federal, Ministro Ilmar Galvão, é uma peça, como disse, eloqüente, 
definitiva e memorável. São 124 páginas de demonstração de sua cultura jurídica, de sua erudição doutrinária e de seu conhecimento técnico do Direito, que podem ser lidas nas págs. 2.191 a 2.315 dos autos da Ação Penal no 307-5. Nela, S. Exa, 1730 ao julgar improcedente a denúncia, concluiu por minha absolvição, no que foi seguido pelo Supremo Tribunal Federal, vencidos os eminentes Ministros Carlos Veloso, Sepúlveda Pertence e Nery da Silveira.

No mesmo sentido foi o parecer do Ministro Moreira Alves, Revisor do processo, cuja erudita manifestação pode ser lida das páginas 2.432 a 2.612 do mesmo

1735 processo. Os votos prolatados demonstraram não só a improcedência da denúncia do Procurador-Geral da República como também o mais importante para mim e minha consciência: a minha absoluta inocência às imputações que, ao longo de todo o processo, foram-me feitas sem consistência, sem comprovação e sem nenhum fundamento.

1740 Como evidenciam os pronunciamentos dos ilustres magistrados que me julgaram, não há, nos autos, nos documentos e nos depoimentos das testemunhas ouvidas, comprovação de nenhum ato ilícito que eu tenha, em qualquer momento, praticado como Presidente da República. Fui afastado na suposição, e tão-somente na suposição, de que as acusações que me fizeram fossem verdadeiras.

1745 Depois de dois anos da mais profunda e abrangente investigação a que um homem público já foi submetido na história do nosso País e da absolvição de todas as imputações que suportei, restaram a mutilação de meu mandato e o ostracismo político que me foi imposto.

Não tive ainda reparados os danos causados à minha honra, à minha dignidade e

1750 ao meu decoro pessoal e político. Enfim, tinha suportado sete meses de torturante expectativa em relação ao meu destino depois de ver atropelado, pela CPMI, pela Câmara dos Deputados e, por que não dizê-lo, pela maioria do Senado, os meus mais comezinhos direitos e até mesmo o elementar benefício da dúvida. Tive de esperar mais dois anos, até 13 de dezembro de 1994, para ver minha inocência

1755 reconhecida em sentença hoje transitada em julgado.

A violência cometida com a suspensão de meus direitos políticos contra a letra expressa da lei e o entendimento majoritário dos doutrinadores não foi, contudo, reparada pela Justiça. Foi, sim, corrigida e remediada pela decisão soberana do povo alagoano $\dot{i}$ o bravo povo alagoano a quem mais uma vez agradeço $\dot{i}$ ao

1760 enviar-me a esta Casa como seu representante, elegendo-me, pela quinta vez. Isto não só me recompensa, mas também me consola e me resgata.

Por isso mesmo, Sr. Presidente, Sras e Srs. Senadores, permito-me evocar perante V. Exas os versos do poeta espanhol Antonio Machado.

1765 O SR. FERNANDO COLLOR (Bloco/PTB $\dot{A} \mathrm{AL}$ ) $¿$ Pois não, Senador Efraim Morais. O Sr. Efraim Morais (PFL ¿ PB) ¿ Senador Fernando Collor, nós que fazemos o Senado Federal temos hoje V. Exa como um dos nossos. E V. Exa vem a esta Casa defender, inicialmente, sua terra querida, Alagoas. V. Exa, que silenciou por muito tempo, hoje, traz a sua versão a esta Casa e ao Brasil inteiro, por intermédio da TV

1770 Senado, dos nossos meios de comunicação. Conta ao Brasil uma história; a história da qual V. Exa faz parte, tendo sido inocentado pelo Supremo, inocentado pelo voto popular de seus conterrâneos ao elegê-lo Senador da República.

Acompanhei todo o processo. Eu era Deputado Federal à época. Devo dizer-Ihe que V. Exa teve a tranqüilidade, a paciência e, acima de tudo, a grande virtude de

1775 contar para o Brasil, hoje, a verdade. Há dois anos passei por uma história parecida quando presidi a CPI dos Bingos nesta Casa. Lá, pude constatar que vários companheiros que tiraram o mandato de V. Exa, tentavam impedir que o Supremo Tribunal Federal quebrasse o sigilo bancário de um simples diretor do atual Governo. Como mudou! Mas isso faz parte da história. Quantos mudaram! Mas isso 1780 faz parte da história! No entanto, a história é o próprio povo brasileiro que julga. V. Exa foi julgado pelos tribunais e pelo povo. Tenho a certeza de que $V$. Exa recomeça com muita força e com credibilidade; credibilidade, por haver enfrentado 
todas essas dificuldades. O Brasil ainda espera muito de V. Exa. E nós, que fazemos o Senado Federal, sentimo-nos honrados de tê-lo como companheiro. Vamos trabalhar pelo Brasil! Todos nós ainda temos muito a fazer pelo nosso País. Parabéns a V. Exa. Sucesso! Que Deus o abençoe nesse reinício, marcado por este pronunciamento. Tenho a certeza de que V. Exa ainda tem muito a dar para o nosso País.

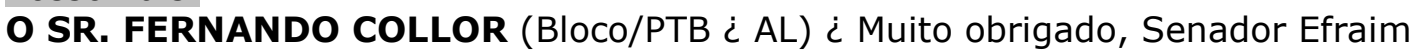

1790 Morais, pela manifestação de V. Exa. Obrigado pela correção com que se houve naqueles episódios de 1992.

E, ao agradecer a V. Exa pela minha acolhida nesta Casa, agradeço também a todos os integrantes do Senado Federal, a começar pelo seu Presidente, Senador Renan Calheiros, companheiro de lutas políticas importantes que travamos juntos,

1795 pela gentileza de, como Presidente desta Casa, acolher-me com tanta fidalguia, com tanto carinho, diria.

Obrigado a todos os Senadores que aqui se pronunciaram. Quero dizer que aqui estou como um Senador igual a todos, sem preconceito, sem qualquer tipo de discriminação.

1800 Obrigado, Senador Arthur Virgílio, também companheiro de geração. Juntos estivemos em alguns momentos importantes da nossa recém iniciada vida pública, tanto a dele quanto a do Presidente Renan Calheiros e a minha. Quantas boas recordações temos daqueles instantes em que o senhor seu pai ainda convivia conosco, e nossas conversas e nossos sonhos eram compartilhados.

1805 Obrigado, enfim, a todos aqueles que se pronunciaram dando-me as boas-vindas e fazendo-me sentir, finalmente, uma pessoa inteira, alguém que traz consigo uma experiência de vida e que deseja colocar à disposição do Senado da República, nos debates aqui sempre realizados, o pouco que eu possa colaborar.

O Sr. Wellington Salgado de Oliveira (PMDB ¿ MG) $¿$ V. Exa me permite um aparte, Senador Fernando Collor?

O SR. FERNANDO COLLOR (Bloco/PTB ¿ AL) ¿ Pois não, desculpe-me, Senador Wellington Salgado de Oliveira.

O Sr. Wellington Salgado de Oliveira (PMDB ¿ MG) ¿ Sr. Presidente, Senador Fernando Collor de Mello, V. Exa me ensinou uma frase de que nunca mais esqueci.

1815 Ouvi, eu não o conhecia. V. Exa era o Presidente do meu País, em quem votei. A frase diz: ¿O tempo é o senhor da razãoc. A primeira vez que a ouvi foi da boca de V. Exa. O tempo está passando, e $V$. Exa vem aqui firme mostrar a sua versão dos fatos. Fiquei aqui ouvindo a história passar, sendo contada por V. Exa, pois nunca Ihe deram a oportunidade de contar. A verdade é essa. Fiquei triste quando V. Exa foi cassado, pela queima de toda uma geração, naquele momento. Minha geração foi queimada naquele momento da cassação. Não foi a cassação de $\mathrm{V}$. Exa, mas a cassação da minha geração. Ouvi, muitas vezes, na minha vida empresarial, dizerem: ¿Olha o que dá votar em jovem! ¿. Ouvi isso. E isso me causava uma angústia tremenda, porque quando votei em V. Exa, e V. Exa era jovem, assim 1825 como aquele grupo, eu sentia a esperança. Por isso, quando V. Exa faz o discurso criticando a emoção com que cassaram o seu mandato, eu também me lembro da emoção de quando V. Exa foi eleito. Na vida política, tentar separar a emoção da vida pública é impossível. Lembro-me daquelas corridas de $\mathrm{V}$. Exa com as pessoas acompanhando. Muitas vezes, acompanhavam V. Exa não para correr, mas porque acompanhavam uma esperança, um líder. E um líder, Presidente Collor, Senador Fernando Collor, não se constrói; um líder já nasce feito. Líder é líder, como um capitão de time, que não se escolhe, nasce naturalmente. V. Exa é um líder. V. Exa passou por esse período todo, um período triste, tanto na vida pública quanto na vida pessoal, e acredito que todos nós sentimos a dor que $V$. Exa sentiu. Ninguém queria passar pelo que $V$. Exa passou. Mas um líder vivo continua um líder. Vejo, no pouco tempo em que $V$. Exa se encontra nesta Casa, ao falar, como as pessoas escutam, como os Senadores ouvem. Um erro que V. Exa cometeu quando era Presidente $\dot{c}$ e é algo que muitos dizem e eu procuro fazer sempre no Senado $\dot{c}$ foi 
não ouvir os mais velhos. Isso é muito importante. Aqui, muitas vezes enfrentei situações difíceis, algumas dentro de CPIs criadas nesta Casa, mas sempre procurei conversar com os mais velhos, com os mais experientes. Naquele momento, faltou isso a V. Exa. Talvez o poder o tenha deixado sozinho. Com o poder, as pessoas ficam muito sozinhas. V. Exa ficou sozinho. E faltou a $V$. Exa pedir um pouco de conselho aos mais velhos. V. Exa foi firme, como está sendo firma agora. Já vi nesta Casa muitas pessoas que passaram por muito menos que $V$. Exa subirem aí e chorarem muito. Choraram muito para ser pelas lágrimas purificados. V. Exa não. V. Exa vem como um homem, citando fatos. Um homem, um líder, não tem jeito. O tempo, está provado isso... Eu, quando tive a oportunidade de me tornar Senador, pretendia fazer duas coisas nesta Casa: a primeira já fiz, que era dizer ao Senador ACM que se o filho dele fosse candidato, eu votaria nele, e tive a oportunidade de dizer isso sozinho ao Senador ACM; a segunda o destino me fez estar aqui neste momento, frente a um ex-Presidente cassado, que, na beleza da nossa democracia, a verdade é essa, ele, cassado, fica fora da vida pública, volta e aqui faz um discurso limpando a sua história, um discurso que ilumina para trás, como um farol de carro. Daqui para frente, Sr. Presidente, esse farol tem de ser virado, tem de iluminar para frente. E eu quero acompanhar V. Exa, quero ver a história onde termina. A história não terminou aqui não, a história não termina com esse discurso, não termina porque tenho participado de comissões com V. Exa. Tenho visto que $V$. Exa tem um caminho longo a percorrer, um caminho que vai mostrar

1860 como funciona a democracia do nosso País. Eu quero estar vivo para ver até onde vai a história de V. Exa. Era o que gostaria de dizer. (Palmas.)

o Sr. Jayme Campos (PFL ¿ MT) ¿ Senador Fernando Collor, V. Exa me permite um aparte?

O SR. FERNANDO COLLOR (Bloco/PTB ¿ AL) ¿ Pois não, Senador Jayme Campos.

O Sr. Jayme Campos (PFL ¿ MT) ¿ Estou aqui desde o início do seu

pronunciamento. Prestei atenção à sua fala. Como seu amigo particular, cumprimento-o pela coragem do pronunciamento, que dá luz a um dos momentos mais dramáticos da história brasileira. E sua fala coloca um ponto final nesse episódio. Com certeza, o povo brasileiro hoje tomou conhecimento, por intermédio

1870 da TV Senado e da Rádio Senado, e amanhã vai tomar, por meio da grande imprensa nacional, da veracidade dos fatos, de tudo o que aconteceu e que entendo ter sido uma grande conspiração contra a sua pessoa. Desejo a V. Exa sucesso na nova missão. Certamente, aos brasileiros de Alagoas, que Ihe deram novamente esse voto de confiança, $\mathrm{V}$. Exa retribuirá com muito trabalho e, acima

1875 de tudo, demonstrando ao Brasil que Collor de Mello sempre será aquele defensor dos oprimidos e dos menos favorecidos da sorte. Saudações, cumprimentos e parabéns pela nova missão.

O SR. FERNANDO COLLOR (Bloco/PTB ¿ AL) ¿ Muito obrigado, Senador Wellington Salgado, pelas palavras de esperança que incute em meu espírito.

1880 Desculpe-me o tropeço de ter talvez feito desvanecer o sonho que $\mathrm{V}$. Exa, ainda jovem, tinha no Presidente, conforme disse, que representava a esperança para a sua geração. Desculpe-me se interrompi esse seu sonho, mas muito obrigado pela confiança.

Obrigado ao Senador Jayme Campos, velho e querido companheiro de lutas políticas. Tantos e bons comícios fizemos em Várzea Grande, quando o Senador era Prefeito daquela querida cidade, e, depois, nos anos em que se seguiram! Ao Senador e ao seu irmão, Júlio Campos, meus agradecimentos.

Mas como eu dizia, Sr. Presidente Renan Calheiros, meus agradecimentos sobretudo a V. Exa pela acolhida, pela forma amiga como me recebeu nesta Casa, pela tolerância de $\mathrm{V}$. Exa e de todos os integrantes da Mesa e das lideranças dos partidos nesta Casa, que me permitiram ultrapassar todos os tempos regimentais para que eu pudesse dar minha versão dos fatos que me levaram ao afastamento da Presidência.

Não me esquecerei deste dia, não me esquecerei deste dia...

1895 Muito obrigado, Senador Renan Calheiros, e, por extensão, a todos os Senadores 
aqui presentes.

Concedo um aparte ao Senador Romero Jucá.

O Sr. Romero Jucá (PMDB ¿ RR) ¿ Presidente Collor, fiz questão de também juntar minha voz a tantas que hoje aqui colocaram no depoimento de $\mathrm{V}$. Exa

1900 emoção, história, um pouco da visão da cada um. V. Exa falou de coração, de alma, com a sua consciência, com o seu preparo, sobre as circunstâncias e os episódios que viveu. Penso que hoje ficou claro para o País o outro lado ¿ aquele que não esteve presente neste plenário há muitos anos. Sem dúvida nenhuma, a partir deste momento, V. Exa encerra esse episódio. Mas, com toda a experiência, com

1905 toda a vivência, com todo o sofrimento, com toda a sua história de vida, V. Exa tem condição de partir para frente e de, neste mesmo plenário, nesta mesma Casa, servir ao País. Tenho certeza de que V. Exa dará uma grande contribuição ao Brasil, a esta Casa e também ao nosso trabalho na Liderança do Governo. Quero pedir o apoio de $\mathrm{V}$. Exa, o auxílio de quem passou pela Presidência da República, com a

1910 visão de iniciar tantos processos novos, modernos, que desaguaram na trajetória que o País vive hoje. Quero contar com o apoio, com a palavra amiga, com a crítica corajosa, com a palavra leal de V. Exa, que é um Senador que chega a esta Casa com história, com biografia e, principalmente, com uma visão de futuro muito grande. Saúdo V. Exa pelo pronunciamento, pela coragem de relembrar tantos

1915 fatos dolorosos. Nós, como companheiros, recebemos V. Exa e o abraçamos. Seremos parceiros no grande trabalho que temos de fazer aqui pelo País. Meus parabéns!

O SR. FERNANDO COLLOR (Bloco/PTB ¿ AL) ¿ Muito obrigado, Senador Romero Jucá, Líder do Governo nesta Casa. V. Exa tem demonstrado toda sua capacidade, 1920 sua competência, seu amor às causas que defende, sua convicção às causas que abraça, que abriga. Quero dizer que V. Exa , como Líder do Governo, pode contar comigo. Sou um soldado seu, seu liderado, esperando apenas suas ordens e orientações para que possamos ajudar o Governo a alcançar as metas que todos nós desejamos, para a felicidade da população brasileira. Muito obrigado a V. Exa .

1925 Ouço o Senador Valdir Raupp.

O Sr. Valdir Raupp (PMDB ¿ RO) ¿ Da mesma forma, nobre Senador, ex-

Presidente Fernando Collor de Mello, quero unir minha voz a todas as vozes que se pronunciaram neste plenário no dia de hoje, e dizer que fui um seguidor de $V$. Exa. Estive, por um período muito curto, no PRN, quando V. Exa foi candidato e depois

1930 Presidente da República. Foi o único período em que fiquei fora do PMDB. Estou no meu quinto mandato, sempre eleito pelo PMDB, mas disputei, em 1990, uma eleição ao Governo do meu Estado pelo PRN, seguindo V. Exa. V. Exa vai se lembrar de uma passagem em que $V$. Exa se deslocou da Presidência da República e foi ao meu Estado, onde visitou uma pequena cidade chamada Cujubim. Eu estava lá. V.

1935 Exa visitou a casa de um casal pobre, uma família que conheço até hoje e que nunca mais esqueceu a visita de V. Exa. Depois, V. Exa subiu ao palanque, fez um pronunciamento sobre ecologia, sobre a Amazônia, sobre o Brasil. Logo em seguida, foi a eleição que disputei. Estive no Palácio do Planalto e fui recebido por V. Exa em audiência; mostrei as pesquisas, em que eu estava muito bem, e V. Exa

1940 falou: ¿Muito bom, muito bom, vá firme, vá em frente! ¿. Fui para o segundo turno, em 1990, e aconteceu uma tragédia. Recebi um golpe. Estava disputando o segundo turno, com $45 \%$ das pesquisas $\dot{c}$ o segundo colocado estava com $31 \% \dot{c}$, e, faltando 20 dias para a eleição, assassinaram meu concorrente, que era o Senador Olavo Pires. No calor da campanha, colocaram a culpa no meu grupo

1945 político, como se eu tivesse mandado assassinar um candidato que estava atrás nas pesquisas do Ibope, da Rede Globo. Perdi a eleição. Em função desse episódio todo, perdi a eleição. Mais tarde, veio a verdade, a justiça foi feita e fui eleito Governador, quatro anos depois, com $62 \%$ dos votos, e o grupo que me acusou acabou sendo derrotado. Então, nunca é tarde para recomeçar. V. Exa está

1950 recomeçando. V. Exa é jovem ainda, tem muito futuro pela frente, muito futuro. Eu me lembro da história de Roberto Marinho, que fundou a Rede Globo com sessenta 
anos. Ele já tinha sessenta anos quando fundou a Rede Globo. E foram mais 37 ou 38 anos, durante os quais tornou a Rede Globo um grande império de comunicação, não só no Brasil, como no mundo. Então, V. Exa ainda pode brilhar muito, ter muito

1955 sucesso. Seja bem-vindo ao Senado Federal. Muito obrigado.

O Sr. Sérgio Zambiasi (Bloco/PTB ¿ RS) ¿ Senador, Presidente Collor, V. Exa me permite um aparte?

O SR. FERNANDO COLLOR (Bloco/PTB $\dot{A} A L)$ ¿ V. Exa tem o aparte, Senador. O Sr. Sérgio Zambiasi (Bloco/PTB ¿ RS) ¿ São raros, realmente muito raros, os 1960 momentos em que esta Casa pára. Na contagem do Senador Roriz, até o momento em que S. Exa, com sua emoção e veemência, manifestou-se, duas horas e trinta e quatro minutos; agora, já se vão mais de três horas, Senador Roriz, três horas e dez minutos. E não é apenas esta Casa, Senador Collor: com certeza, milhões de brasileiros estão acompanhando seu pronunciamento. Este, sem dúvida nenhuma,

1965 é um momento para a História. Chegando aqui, momentos antes de V. Exa iniciar sua manifestação, fui surpreendido por uma eleitora, que agarrou em meu braço e disse: ¿Eu preciso assistir, é um momento histórico, foi o meu primeiro voto! ¿. Ela tinha, na época, 16 anos. Aquela geração, seguramente, estava na expectativa de ouvir esse outro lado, testemunhado por alguém que estava aqui ao meu lado, o

1970 ex-Deputado Roberto Jefferson, que foi solidário com V. Exa naqueles dias de massacre e posteriormente também, a ponto de hoje estarmos juntos na mesma fileira, no Partido Trabalhista Brasileiro. Eu me emocionei com a emoção do Senador Romeu Tuma, comovi-me com suas manifestações e com suas lágrimas. São lágrimas, não tenho nenhuma dúvida, que ajudam a marcar este momento 1975 importante da democracia brasileira. O Senador Collor está hoje escrevendo uma página extremamente importante da nossa história, uma página que fala de injustiça e de justiça, uma página que, não tenho dúvidas, fica marcada na história da política brasileira. Quantos estavam nessa expectativa? Confesso que eu, que sou seu companheiro de Bancada, não tive coragem de lhe perguntar, nesses dias

1980 que antecederam este momento, como seria, mas todos tínhamos uma grande expectativa. Como será o pronunciamento? Que linha o Senador Collor vai adotar? A do ódio? A da vingança? A da raiva? A da denúncia? Esses saíram frustrados, Senador Collor. V. Exa adota a linha serena de quem fez a travessia de todas essas dificuldades e amadureceu; entende a responsabilidade deste momento e oferece 1985 ao Brasil, em vez do ódio, da denúncia, da raiva, oferece o seu compromisso com a governabilidade. Isso, realmente, é admirável! É uma lição, sem dúvida nenhuma, para todos nós, uma lição política que todos estamos recebendo hoje, diante da sua sereníssima manifestação, uma manifestação que todos nós, brasileiros, queríamos ouvir. Mas, antes e acima de tudo, eu entendo, Senador Collor, que esta é uma

1990 homenagem à sua história, à sua vida e ¿ permita-me citar mais três pessoas que são absolutamente essenciais, como já manifestado por V. Exa por ocasião do ingresso no PTB $\dot{c}$ à sua esposa, Caroline, que está aqui lhe assistindo, pacientemente, solidariamente. Lembro-me do seu pronunciamento, na sede do diretório, quando $\mathrm{V}$. Exa dizia que havia uma pessoa responsável pela decisão da

1995 sua candidatura ao Senado. Foi ela que Ihe estimulou, que Ihe deu força, que Ihe deu energia e que, enfim, acompanhou $V$. Exa nesse desafio do resgate pelas urnas, que é, seguramente, o melhor de todos os resgates, junto com a Celine e a Cecília, suas gêmeas. Imagino que, acima de tudo, este dia e esta jornada devem ser dedicados a essas três pessoas. Parabéns, companheiro Fernando Collor de

\section{Mello!}

O SR. FERNANDO COLLOR (Bloco/PTB ¿ AL) ¿ Muito obrigado, Senador Sérgio Zambiasi, querido amigo e companheiro, integrante das fileiras do nosso Partido Trabalhista Brasileiro, pela lembrança que faz do nome de minha mulher, que, sem dúvida, foi quem decidiu a minha candidatura. Tenho a foto do dia da diplomação, que fiz questão de tirar com ela, segurando o diploma, porque mais da metade daquele diploma pertence a ela e às minhas filhas, que V. Exa, tão generosamente, cita, Senador Sérgio Zambiasi.

Também temos gratas recordações de momentos passados juntos em anos em que 
V. Exa , numa demonstração de coragem, de altruísmo, de imparcialidade, recebeume em seu programa de rádio em Porto Alegre, a despeito das enormes pressões em contrário, e abriu os microfones do seu programa para que eu pudesse falar. Quis o destino que hoje estivéssemos juntos. Não posso deixar de me lembrar, quando sempre falo com $\mathrm{V}$. Exa, de minhas raízes gaúchas. Orgulho-me delas. Falando em PTB, também agradeço o sacrifício que vem sendo feito pelo nosso

2015 Líder, Senador Epitácio Cafeteira, que, durante todo esse tempo, acompanha o nosso discurso, tendo tantos compromissos. Sei que sua senhora sempre o chama para atender os compromissos que tem.

V. Exa, com sua disposição de ouvir, presenteia-me e deixa-me muito orgulhoso do meu Líder, Senador Epitácio Cafeteira.

2020 Senador Valdir Raupp, lembro-me muito bem desses momentos, da nossa torcida pela eleição de V. Exa em 1990. Lembro-me bem desse episódio, do trauma que causou à sua vida a acusação injusta que Ihe foi imposta. Mais tarde, a justiça de Deus se fez e ficou demonstrada sua completa e absoluta inocência diante daquele fato tão triste para todos nós. Parabéns por sua brilhante carreira política! Parabéns pela forma como V. Exa se conduz na Liderança do PMDB nesta Casa! Muito obrigado pelos votos de boas-vindas que $\mathrm{V}$. Exa me oferece.

\section{O Sr. Edison Lobão (PFL ¿ MA) ¿ V. Exa me concede um aparte?}

O SR. FERNANDO COLLOR (Bloco/PTB $i \mathrm{AL}$ ) $¿$ Pois não, Senador Edison Lobão. O Sr. Edison Lobão (PFL ¿ MA) ¿ Desde logo, louvo a serenidade, a sobriedade

2030 com que V. Exa expõe a sua versão. Ela faltava à História política deste País e não deveria ser sonegada. V. Exa o faz do alto da tribuna da mais alta Casa do Congresso Nacional. Fomos colegas na Câmara dos Deputados. No passo seguinte, eu era Governador e V. Exa , Presidente da República. V. Exa sempre me recebeu em seu gabinete com extrema cordialidade e com extrema rapidez até nas

2035 audiências que eu solicitava. Antes mesmo desse episódio que culminou com a queda de V. Exa da Presidência da República, houve nuvens que se adensaram em torno da presidência de $V$. Exa . De algum modo, tive até alguma participação no sentido de removê-las, ou de contribuir para que isso acontecesse. $O$ destino dos políticos, muitas vezes, é incontrolável. Ainda há pouco, V. Exa citou Cícero. Não 2040 devemos nos esquecer de que o colega de Cícero, Júlio César, também caiu, de maneira trágica até. V. Exa mencionou Getúlio Vargas, Pedro I e Pedro II. O Imperador Pedro II, em certo momento, recebe a visita de um major, o Major Sólon, que Ihe disse que ele não era mais imperador; sumária, a comunicação. Com V. Exa, houve um processo ¿ tumultuado; não foi longo, mas houve algum tempo

2045 ainda. Indira Gandhi, Primeira-Ministra da Índia, teve momentos em que se submeteu também a um processo e caiu de maneira estrepitosa e até perigosa. No passo seguinte, voltou à política com a mesma força e com o mesmo entusiasmo. Isso é da vida pública. Lamentavelmente, tais solavancos ocorrem e fazem parte da vida pública. V. Exa chega ao Senado Federal e aqui recomeça a sua caminhada.

2050 Foi bom que tivesse feito esse depoimento. Ele faltava à História política deste País. Seja feliz, Senador Fernando Collor! (Palmas.)

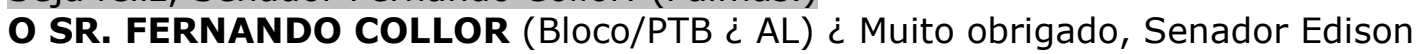
Lobão. Somos companheiros já de longa data, como disse V. Exa, companheiros de Câmara dos Deputados. Ambos jornalistas, ambos do Nordeste $\dot{~ o ~ n o s s o ~ q u e r i d o ~}$

2055 Nordeste $\dot{c}$, ambos ex-Governadores, e, agora, nos encontramos no Senado, onde precisarei obter de V. Exa as lições e as considerações que, com sua experiência, sem dúvida, poderá oferecer-me. Obrigado.

Sr. Presidente, Sras e Srs. Senadores, mais uma vez, agradecendo pela paciência, evocaria os versos do poeta espanhol Antonio Machado:

2060 Nossas horas são minutos

Quando esperamos saber,

E séculos quando sabemos

O que se pode aprender.

Hoje, dia 15 de março de 2007, conforme V. Exa ${ }^{a}$ afirmaram, posso virar 
2065 definitivamente aquelas páginas doídas da minha vida pública e, finalmente, invocar o personagem Marco Antônio, na peça Júlio César, há pouco citado pelo Senador Edison Lobão. Diz Marco Antônio: ¿I come to bury Caesar, not to praise himi.

Como ele, Sr. Presidente, Sras e Srs. Senadores, não vim lastimar o passado. Eu

2070 vim para sepultar, com a permissão de V. Exás, de vez, essa dolorosa lembrança. Muito obrigado a todos os senhores. (Palmas.) 


\section{ANEXO G}

Reprodução da imagem do texto publicado na Revista Veja, edição 2172 - ano 43 - nº. 27, de 7 de julho de 2010, de versão de um segmento do discurso proferido por Fernando Collor, na capital Maceió, em 30 de junho de 2010, no lançamento de sua candidatura ao governo de Alagoas. Acompanha a transcrição da voz de Fernando Collor, segundo as normas instituídas pelo projeto NURC/SP, do audiovisual do segmento correspondente, recuperado por meio do link de arquivo eletrônico de imagens acessado em 26/08/2010: http://www.youtube.com/watch?v=fSd89VeqwlQ\&feature=related, com reprodução em mídia digital.

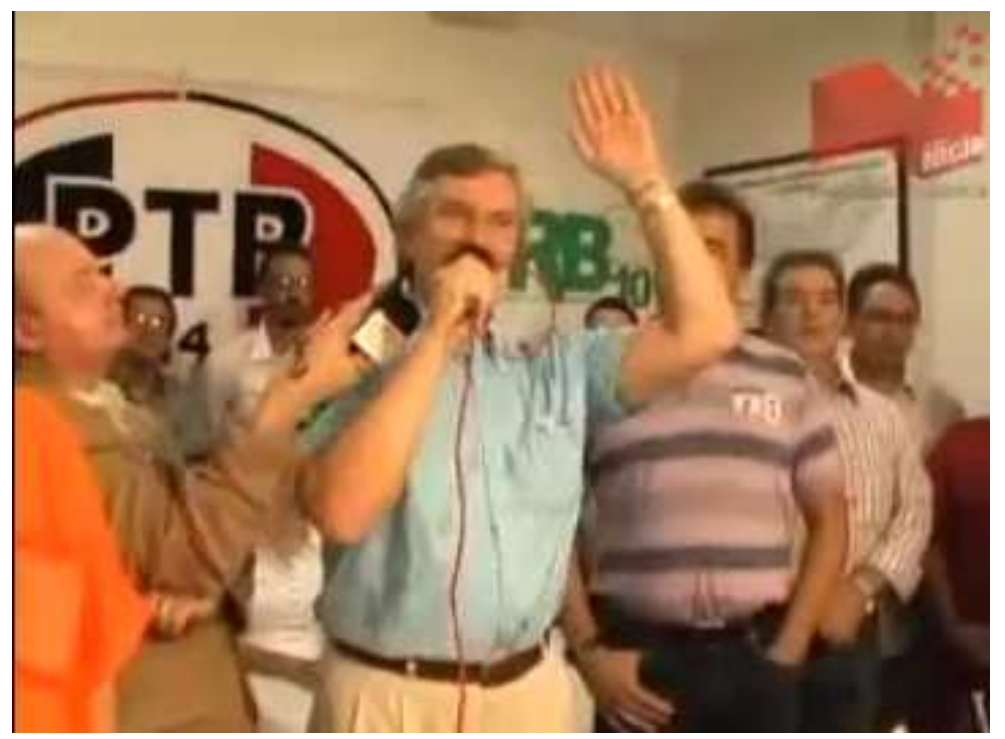

Imagem recuperada do referido vídeo 


\section{"Dou um recado aos bandidecos de m...: que saiam de Alagoas, ou vão sentir a minha mão mais pesada, que vai cair sobre eles.}

FERNANDO COLLOR DE MELLO, candidato ao govemo de Alagoas, no seu velho estilo bandidão

TRANSCRIÇÃO DO AUDIOVISUAL (voz de Fernando Collor de Mello):

(e) a minha mão peSAda vai cair em cima deles:... ((aplausos)) e eles vão deixar:.... e eles vão deixar:.... vão deixar:: a sociedade alagoana em paz... 


\section{ANEXO H}

Normas para Transcrição - Projeto NURC/SP.

O Projeto da Norma Urbana Culta instituiu as regras que seguem para serem utilizadas na coleta de dados que efetuou no período de 1971 a 1978, com o objetivo de estudar a Norma Linguística Urbana Culta do Brasil. Tais normas encontram-se publicadas em:

PRETI, D. e URBANO, H. (Org). A linguagem falada culta na cidade de São Paulo. São Paulo: T. A. Queiro, Fapesp, 1990. v. 4. 
Normas para Transcrição - Projeto NURC/SP

OCORÊNCIAS

\begin{tabular}{|c|c|c|}
\hline $\begin{array}{l}\text { Incompreensão de palavras ou } \\
\text { segmentos }\end{array}$ & ( ) & $\begin{array}{l}\text { do nível de renda...( ) } \\
\text { nível de renda nominal... }\end{array}$ \\
\hline Hipótese do que se ouviu & (hipótese) & $\begin{array}{l}\text { (estou) meio preocupado (com o } \\
\text { gravador) }\end{array}$ \\
\hline $\begin{array}{l}\text { Truncamento (havendo homografia, } \\
\text { usa-se acento indicativo da tônica } \\
\text { e/ou timbre) }\end{array}$ & l & e comé/ e reinicia \\
\hline Entoação enfática & maiúscula & porque as pessoas reTÊM moeda \\
\hline $\begin{array}{l}\text { Prolongamento de vogal e } \\
\text { consoante (como s, r) }\end{array}$ & $\begin{array}{c}:: \text { podendo aumentar para ::.:: ou } \\
\text { mais }\end{array}$ & $\begin{array}{l}\text { ao emprestarem os... éh:.: .... } \\
\text { dinheiro }\end{array}$ \\
\hline Silabação & - & por motivo tran-sa-ção \\
\hline Interrogação & $?$ & eo Banco... Central... certo? \\
\hline Qualquer pausa & $\cdots$ & $\begin{array}{l}\text { são três motivos... ou três razões... } \\
\text { que fazem com que se retenha } \\
\text { moeda... existe uma... retenção }\end{array}$ \\
\hline $\begin{array}{l}\text { Comentários descritivos do } \\
\text { transcritor }\end{array}$ & ((minúsculas)) & $(($ tossiu $))$ \\
\hline $\begin{array}{l}\text { Comentários que quebram a } \\
\text { seqüência temática da exposição; } \\
\text { desvio temático }\end{array}$ & ---- & $\begin{array}{l}\text {... a demanda de moeda -- vamos } \\
\text { dar essa notação -- demanda de } \\
\text { moeda por motivo }\end{array}$ \\
\hline $\begin{array}{l}\text { Superposição, simultaneidade de } \\
\text { vozes }\end{array}$ & $\{$ ligando as linhas & $\begin{array}{l}\text { A. na }\{\text { casa da sua irmã } \\
\text { B. sexta-feira? } \\
\text { A. fizeram }\{\text { lá... } \\
\text { B. cozinharam lá? }\end{array}$ \\
\hline $\begin{array}{l}\text { Indicação de que a fala foi tomada } \\
\text { ou interrompida em determinado } \\
\text { ponto. Não no seu início, por } \\
\text { exemplo. }\end{array}$ & $(\ldots)$ & (...) nós vimos que existem... \\
\hline $\begin{array}{l}\text { Citações literais ou leituras de } \\
\text { textos, durante a gravação }\end{array}$ & " " & $\begin{array}{l}\text { Pedro Lima... ah escreve na } \\
\text { ocasião... "O cinema falado em } \\
\text { língua estrangeira não precisa de } \\
\text { nenhuma baRREIra entre nós"... }\end{array}$ \\
\hline
\end{tabular}

* Exemplos retirados dos inquéritos NURC/SP No. 338 EF e 331 D². $^{2}$

\section{Observações:}

1. Iniciais maiúsculas: só para nomes próprios ou para siglas (USP etc.)

2. Fáticos: ah, éh, eh, ahn, ehn, uhn, tá (não por está: tá? você está brava?)

3. Nomes de obras ou nomes comuns estrangeiros são grifados.

4. Números: por extenso.

5. Não se indica o ponto de exclamação (frase exclamativa).

6. Não se anota o cadenciamento da frase.

7. Podem-se combinar sinais. Por exemplo: oh::.... (alongamento e pausa).

8. Não se utilizam sinais de pausa, típicos da língua escrita, como ponto-e-vírgula, ponto final, dois pontos, vírgula. As reticências marcam qualquer tipo de pausa, conforme referido na Introdução. 


\section{ANEXO I}

Reprodução em mídia digital da propaganda da campanha a presidente da República (ANEXO A) e do segmento de discurso da campanha a governador de Alagoas (ANEXO G). 